Capacity Assessment for Earth Monitoring, Analysis, and Prediction (EarthMAP) and Future Integrated Monitoring and Predictive Science at the U.S. Geological Survey

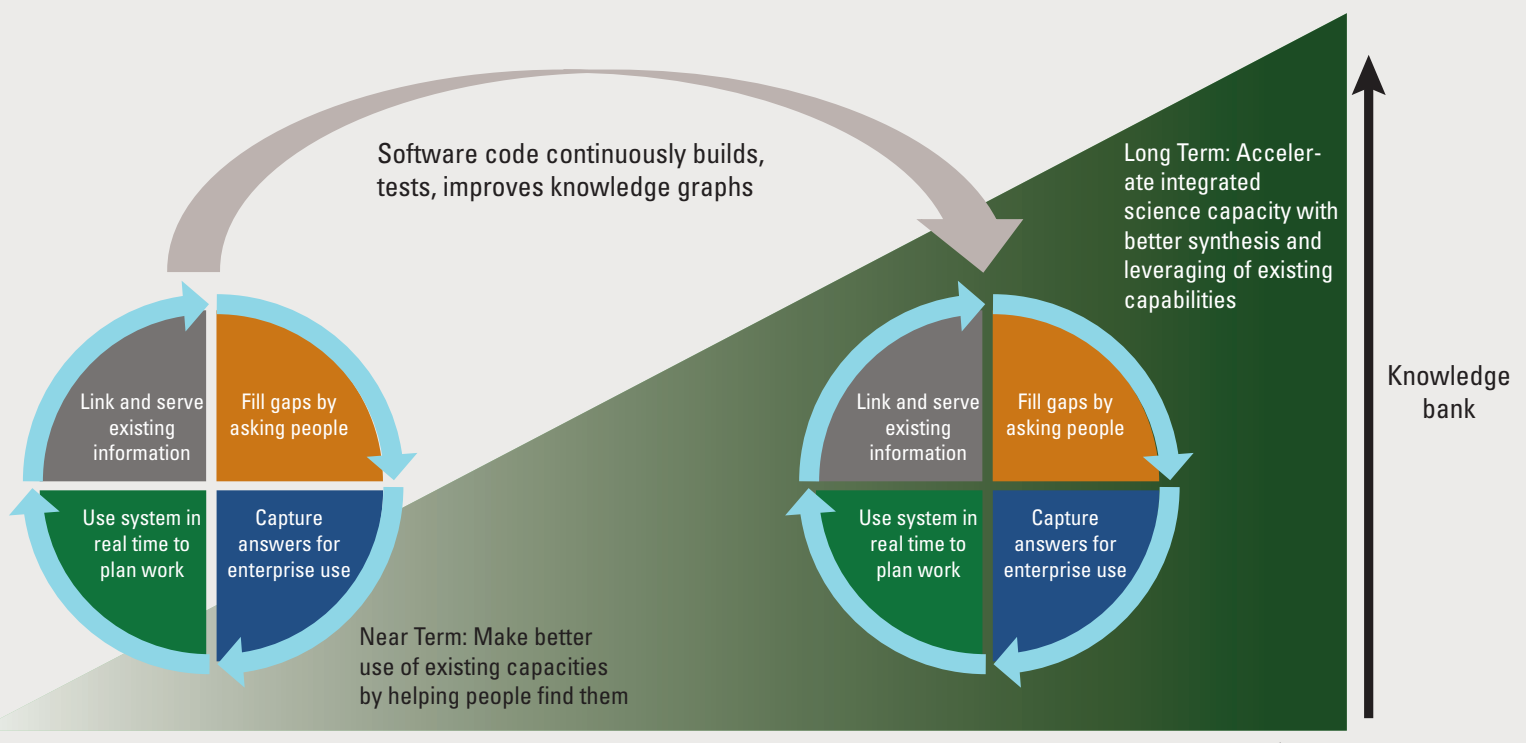

Open-File Report 2021-1102 $x=3$
$y$
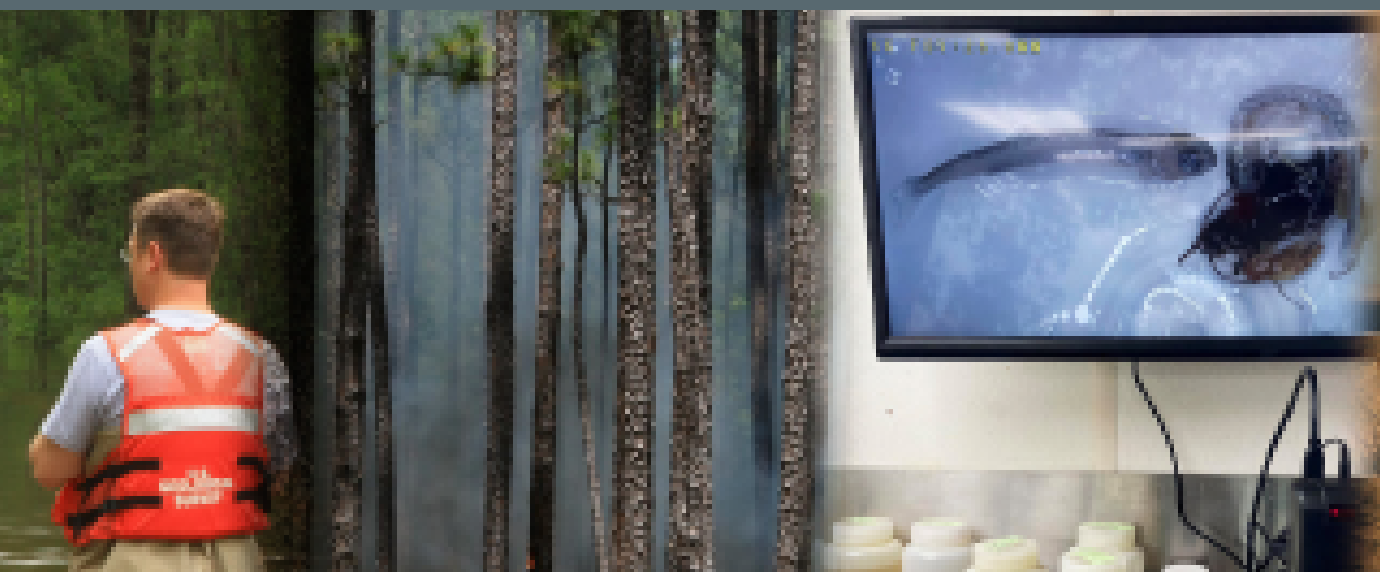


\begin{tabular}{|l|l|l|l|}
\hline 1 & 2 & 3 & \\
& & & \\
& & & \\
& & & \\
\hline
\end{tabular}

Cover. 1. Flooding from Altamaha River on Altamaha Park road in Glynn County, Georgia. Photograph by Alan Cressler, U.S. Geological Survey, April 14, 2009.

2. Prescribed burn, St. Marks National Wildlife Refuge in Walulla County, Florida. Photograph by Alan Cressler, U.S. Geological Survey, April 30, 2008.

3. Larval fish collected during icthyoplankton sampling in Lake Michigan. Photograph by Patricia Armenio, U.S. Geological Survey, July 17, 2020.

4. Butterowe Bayou, Galveston Island State Park, Galveston, Texas. Photograph by Alan Cressler, U.S. Geological Survey, November 6, 2007. 


\section{Capacity Assessment for Earth Monitoring, Analysis, and Prediction (EarthMAP) and Future Integrated Monitoring and Predictive Science at the U.S. Geological Survey}

By Jennifer L. Keisman, Sky Bristol, David S. Brown, Allison K. Flickinger, Gregory Gunther, Peter S. Murdoch, MaryLynn Musgrove, John C. Nelson, Gregory D. Steyer, Kathryn A. Thomas, and Ian R. Waite

Open-File Report 2021-1102 


\section{U.S. Geological Survey, Reston, Virginia: 2021}

For more information on the USGS - the Federal source for science about the Earth, its natural and living resources, natural hazards, and the environment—visit https://www.usgs.gov or call 1-888-ASK-USGS.

For an overview of USGS information products, including maps, imagery, and publications, visit https://store.usgs.gov/.

Any use of trade, firm, or product names is for descriptive purposes only and does not imply endorsement by the U.S. Government.

Although this information product, for the most part, is in the public domain, it also may contain copyrighted materials as noted in the text. Permission to reproduce copyrighted items must be secured from the copyright owner.

Suggested citation:

Keisman, J.L., Bristol, S., Brown, D.S., Flickinger, A.K., Gunther, G., Murdoch, P.S., Musgrove, M., Nelson, J.C., Steyer, G.D., Thomas, K.A., and Waite, I.R., 2021, Capacity assessment for Earth Monitoring, Analysis, and Prediction (EarthMAP) and future integrated monitoring and predictive science at the U.S. Geological Survey: U.S. Geological Survey Open-File Report 2021-1102, 110 p., https://doi.org/10.3133/ofr20211102.

Associated data for this publication:

Nelson, J.C., Brown, D.S., Flickinger, A.K., Gunther, G.L., Keisman, J.L., Murdoch, P.S., Steyer, G.D., Thomas, K.A., and Waite, I.R., 2021, USGS Earthmap Capacity Assessment Dataset: U.S. Geological Survey data release, https://doi.org/10.5066/P9BB5NMZ.

ISSN 2331-1258 (online) 


\section{Contents}

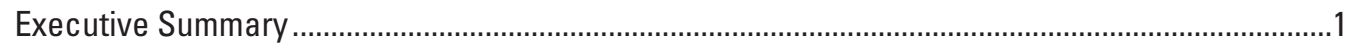

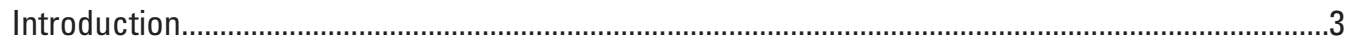

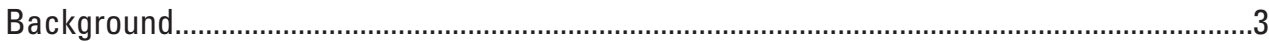

Earth Monitoring, Analysis, and Prediction Capacity Assessment Team Charge .....................4

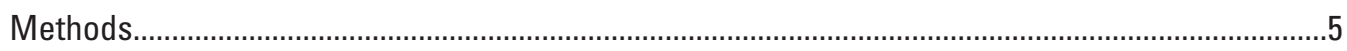

Survey Development and Deployment..........................................................................

Survey Results Augmentation ..........................................................................................

Dynamically Updated Capacity Information Proof-of-Concept ..................................................

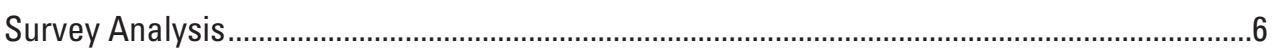

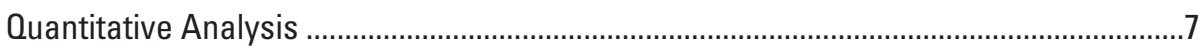

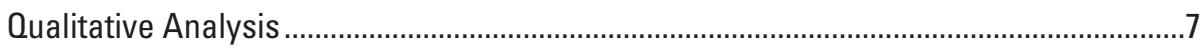

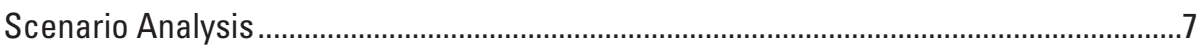

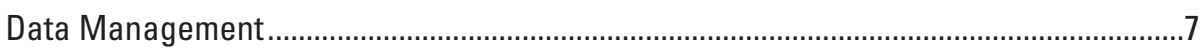

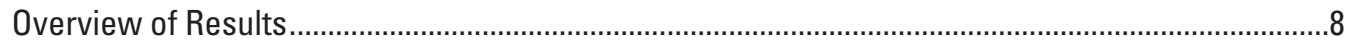

Survey Respondent Characteristics: Region, Mission, and Discipline Distribution ...................

Reported Skill Levels in Identified Scientific and Technical Areas.......................................10

Characterization of Data Integration, Predictive Modeling, Science Integration, and Information Delivery Activities....................................................................................12

Data and Information Integration..............................................................................12

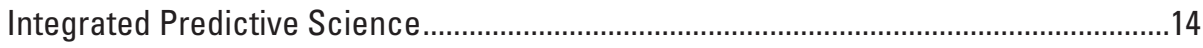

Delivery of Actionable Information ...................................................................................

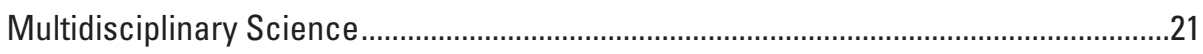

Communities of Practice ..............................................................................................22

Dynamically Updated Capacity Assessment Information.......................................................22

Key Findings, Lessons Learned, and Recommendations ..............................................................22

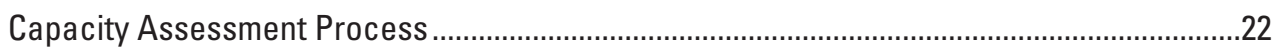

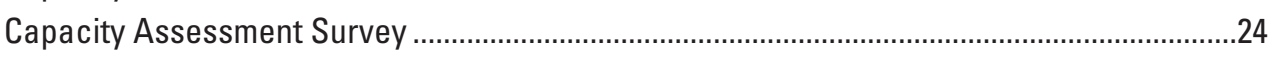

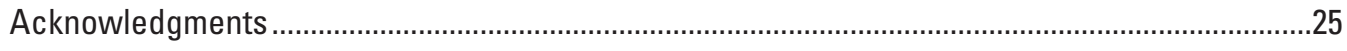

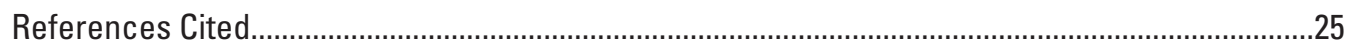

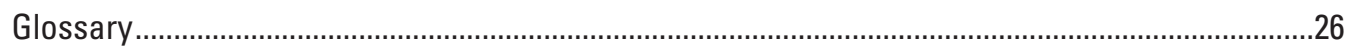

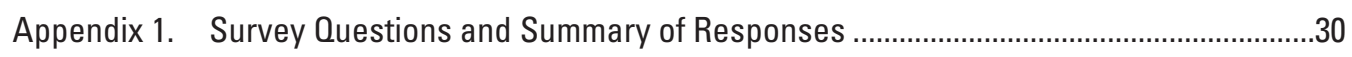

Appendix 2. Operational Ecological Forecasting ....................................................................47

Appendix 3. Submitted and Identified Websites and Data Web Applications ...............................50

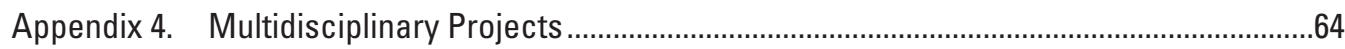

Appendix 5. Methods and Techniques for Dynamically Assembling Scientific

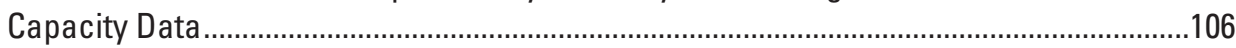




\section{Figures}

1. Diagram showing vision for an integrated approach to U.S. Geological Survey science that enables better delivery of actionable information to address increasingly complex decision needs for managing interconnected human and natural Earth systems and rapidly responding to natural hazards as they arise..

2. Diagram showing the Earth Monitoring, Analysis, and Prediction science and information delivery framework that integrates traditional scientific disciplines and the full portfolio of U.S. Geological Survey science activities: research, monitoring, modeling, analyses, and information delivery...

3. Graphs showing survey response by U.S. Geological Survey mission area and region.

4. Graph showing distribution of respondents across U.S. Geological Survey Earth systems science disciplines, corresponding to those described in Jenni and others (2017).

5. Graph showing distribution of reported expertise in listed skills

6. Graphs showing distribution of reported expertise in a suite of data collection and processing technologies identified in the "Grand Challenges" report..

7. Graph showing reported use of nontraditional data sources

8. Graph showing reported barriers to utilizing new or currently available data collection and processing technologies

9. Graph showing reported use of the listed predictive modeling approaches

10. Graphs showing responses to the survey question "At what spatial scale(s) have you worked?"

11. Graphs showing responses to the survey question "To what extent is prediction currently being used in your temporal analysis?"

12. Graph showing number of respondents who identified the listed organizations or groups as one of their stakeholders.

13. Graph showing decision classes for stakeholder decisions addressed by the U.S. Geological Survey.

14. Graph showing number of respondents who reported incorporating decision science into their work in one or more of the listed ways.

15. Graph showing number of respondents who used the listed science communication approaches for information delivery to non-scientific audiences

16. Graph showing number of respondents who identified the listed barriers as limiting their ability to incorporate more stakeholder engagement, decision science, and innovative science communication approaches into their work .21

17. Diagram showing vision for a continuous capacity assessment capability .23

\section{Tables}

1. Survey respondents by discipline of position title

2. Number of respondents who have been involved in projects that provide actionable information to stakeholders on one or more of a select set of Grand Challenge science needs

3. Number of respondents reporting a select set of data integration efforts. 


\section{Supplemental Information}

A Glossary is included after the "References Cited" section.

\section{Abbreviations}

$\begin{array}{ll}\text { Al/ML } & \text { Artificial Intelligence/Machine Learning } \\ \text { CAT } & \text { Capacity Assessment Team } \\ \text { CoP } & \text { Community of Practice } \\ \text { DOI } & \text { digital object identifier } \\ \text { EarthMAP } & \text { Earth Monitoring, Analysis, and Prediction } \\ \text { HPC } & \text { high performance computing } \\ \text { iSAID } & \text { Integrated Science Assessment Information Database } \\ \text { ORCID } & \text { Open Researcher and Contributor ID } \\ \text { RFI } & \text { Request for Information } \\ \text { URL } & \text { Uniform Resource Locator } \\ \text { USDOI } & \text { U.S. Department of the Interior } \\ \text { USGS } & \text { U.S. Geological Survey }\end{array}$





\title{
Capacity Assessment for Earth Monitoring, Analysis, and Prediction (EarthMAP) and Future Integrated Monitoring and Predictive Science at the U.S. Geological Survey
}

\author{
By Jennifer L. Keisman', Sky Bristol2 ${ }^{2}$ David S. Brown³, Allison K. Flickinger ${ }^{4}$, Gregory Gunther ${ }^{5}$, \\ Peter S. Murdoch ${ }^{6}$, MaryLynn Musgrove ${ }^{3}$, John C. Nelson7 , Gregory D. Steyer ${ }^{8}$, Kathryn A. Thomas ${ }^{9}$, and \\ Ian R. Waite ${ }^{10}$
}

\section{Executive Summary}

Managers of our Nation's resources face unprecedented challenges driven by the convergence of increasing, competing societal demands and a changing climate that affects the stability, vulnerability, and predictability of those resources. To help meet these challenges, the scientific community must take advantage of all available technologies, data, and integrative Earth systems modeling capacity to better inform resource and risk management decisions. This is the overarching goal of the U.S. Geological Survey (USGS) Earth Monitoring, Analysis, and Prediction (EarthMAP) vision: "By 2030, the USGS will deliver well integrated observations and predictions of the future state of natural systems - water, ecosystems, energy, minerals, hazards - at regional and national scales, working primarily with federal, state, and academic partners to develop and operate the capability" (U.S. Geological Survey, 2021).

\footnotetext{
${ }^{1}$ Maryland-Delaware-District of Columbia Water Science Center.

${ }^{2}$ Science Analytics and Synthesis.

${ }^{3}$ Oklahoma-Texas Water Science Center.

${ }^{4}$ New Mexico Water Science Center.

${ }^{5}$ Central Energy Resources Science Center.

${ }^{6}$ Northeast Regional Director's Office.

${ }^{7}$ Midwest Regional Director's Office.

${ }^{8}$ Southeast Regional Director's Office.

${ }^{9}$ Southwest Biological Science Center.

${ }^{10}$ Oregon Water Science Center.
}

Providing more integrated Earth systems science and actionable information to decision makers, stakeholders, and the public requires a better understanding of the depth and distribution of existing capacity (capabilities, tools, and techniques) across the Bureau. Identifying existing capacity is also a critical first step toward gap analysis and targeted investments to increase capacity over time. The USGS formed a Capacity Assessment Team (CAT) and charged it with (1) conducting a Request for Information (RFI) to identify existing USGS expertise and activities supportive of integrated and predictive science to inform decision making, (2) developing a strategy and proof-of-concept for a continuously updated capacity assessment capability, and (3) identifying lessons learned to inform development of best practices for future capacity assessment efforts.

The RFI took the form of a survey, with content guided by the science and technology needs identified in a USGS report titled "Grand Challenges for Integrated U.S. Geological Survey Science-A Workshop Report" (Jenni and others, 2017), herein referred to as "Grand Challenges." The 44-question survey provided respondents the ability to rate their level of experience with a suite of priority disciplines, analysis and modeling approaches, technologies, and stakeholder engagement strategies and to enter optional narrative text for supporting context. An introductory portion focused on general science capacity assessment, followed by three sections targeting capabilities related to the foundational components of EarthMAP: (1) data and information integration, (2) integrated predictive science, and (3) actionable information. 
The survey results provided a high-level snapshot of USGS capacity in the targeted areas. Respondents (1,035 individuals) represented approximately 13 percent of the USGS across all mission areas and regions. Seventy-four percent of the respondents held a science-focused position title and the remainder had position titles in information technology, computer science, management, administrative, or other (contractors, volunteers, emeritus, and unknown). To provide greater insight into respondent capabilities and activities, information from the U.S. Department of the Interior and USGS enterprise information systems were used to further characterize topical expertise and organizational associations of survey respondents. To address the ongoing need to assess the Bureau's capacity to address integrated predictive science priorities, the CAT developed a software-based proof-of-concept called the Integrated Science Assessment Information Database (iSAID) for assembling various information sources together toward making the full extent of USGS capabilities and scientific assets available for routine capacity assessment. This proof-of-concept is intended to serve as a catalyst for further development. The process of implementing the EarthMAP capacity assessment survey, analyzing survey responses, and developing the proof-of-concept resulted in lessons learned, findings, and recommendations. Example scenarios throughout the report demonstrate how capacity assessment data can inform science planning. Three overarching findings and recommendations are:

(1) Finding: Capacity is limited in some critical disciplines, skills, and technology applications, but "sufficient" depends on the question and the need relative to availability at a given point in time.

Recommendation: Develop an on-demand capacity assessment framework that enables rapid identification and evaluation of existing and available expertise to support decision needs as they arise.

(2) Finding: Institutional barriers and lack of awareness constrain the ability of USGS staff to adopt new technologies, collaborate across administrative boundaries, and deliver actionable information to stakeholders in a timely manner. However, these barriers are not universally experienced.

Recommendation: Pursue more targeted inquiries to clarify which institutional barriers are obstructing the adoption of new technologies and approaches or the sharing of expertise and equipment across organizational and regional boundaries. These inquiries should inform USGS leadership, mission areas, and regions whether policies can be revised or whether a lack of understanding is creating perceived obstacles. Highlight cases when staff have successfully adopted new technologies and approaches to advance EarthMAP priorities and provide actionable information in a timely manner to spread awareness of how perceived obstacles can be navigated and overcome when appropriate.

(3) Finding: Examples of people and projects integrating across disciplines and scales and applying advanced approaches to meet complex stakeholder needs exist. Such examples provide transfer value across the spectrum from approach to decision making. Many projects, already underway, appear to meet elements of the EarthMAP vision, and the USGS has people who can provide leadership in multiple types of specific integrated science efforts.

Recommendation: Use these findings as a starting point for near-term strategic planning for integrated science. Highlight, incentivize, and build on existing interdisciplinary predictive science and information delivery activities across the USGS to advance toward further realization of an EarthMAP capacity.

The CAT efforts to develop and assess existing USGS capacity to advance the EarthMAP vision revealed a fundamental challenge for not only this effort but any effort to assess existing capacity: A considerable amount of thought, time, and effort is required to survey and assess capabilities and tools available to support a given need, yet best results are still likely to provide an incomplete assessment. To better meet the frequent need to assess capabilities, tools, products, and projects that address an expressed strategic priority, the CAT proposes the concept of an on-demand capacity assessment framework supported by a software package that dynamically pulls and integrates information from existing USGS information systems and public domain registries. Although existing USGS enterprise information systems currently lack the structure, cross-system consistency, interoperability, and stability to support a continuously updated capacity assessment capability, we identify reasonable near-term steps to improve the utility of information gathered on expertise and project capacity and to improve the consistency and completeness of information and the ability of USGS systems to share that information. The ability to search and characterize this information will make future assessments of capacity faster, more complete, more efficient, and more targeted. This approach would grow the Bureau's capacity knowledge over time, iteratively improving the ability to access, leverage, and synthesize existing capabilities and assets as well as identify and fill critical gaps. The greatest promise for developing integrated science could lie in linking across existing projects and expertise to create a multi-project capacity for addressing large, complex environmental issues. 


\section{Introduction}

\section{Background}

Managers of our Nation's resources are facing unprecedented challenges driven by the convergence of increasing, competing societal demands and a changing climate that is affecting the stability, vulnerability, and predictability of those resources. Addressing these challenges requires harnessing and integrating innovative scientific approaches, technologies, and research insights into Earth system functioning, with a focus on advancing our understanding in ways that can better inform decision making and natural resource management. Science must be increasingly interdisciplinary and multiscale, involve stakeholders at all stages of research development, and be able to address management needs in a format and within the timeframes and geographical scales needed to be useful for decision making.

A workshop was held in February 2017 to identify societal "grand challenges"-defined as "fundamental problems with broad societal consequences and solutions in Earth system science" - that U.S. Geological Survey (USGS) expertise is well poised to address and to discuss the scientific expertise, technology advances, and stakeholder engagement strategies needed to address them. A main theme was the need for all of these components to operate in a well integrated, interdisciplinary manner to better predict changes in the coupled human-natural Earth system and to regularly create and deliver science that is used to support decision making; this theme evolved into the Earth Monitoring, Analysis, and Prediction (EarthMAP) vision (fig. 1; Jenni and others, 2017).

Data and information integration supports all facets of the foundational EarthMAP vision and is fundamental to the core USGS mission. In this context, successful data and information integration is described as an efficient and effective enterprise-wide framework for collecting, assessing, analyzing, and integrating science data and information. Designing "transfer value" into project design, so that research knowledge gained at one location can be extrapolated and translated to other locations where resource management decisions are being made, greatly expedites the science-based decision process.

Predictive science is the use of techniques to better understand the complexity of environmental processes and conditions, usually by using models that predict interactions, rates, or future conditions, and can be used to help make better management decisions. Models can help us understand important mechanisms as well as predict future events so that managers and stakeholders can evaluate and compare scenarios and management options for better planning. Predictive science often relies on the application of multiple models across a variety of disciplines to try to better capture the full complexity of various natural systems at diverse temporal and spatial scales.

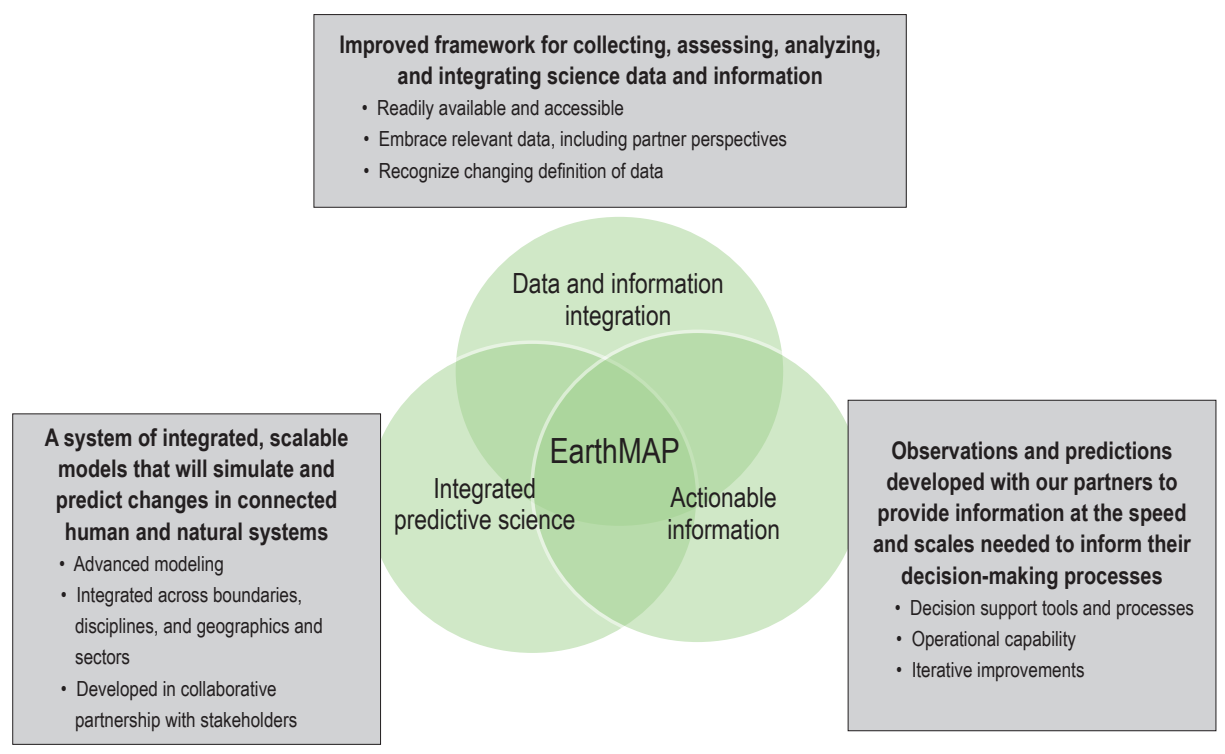

Figure 1. Vision for an integrated approach to U.S. Geological Survey science that enables better delivery of actionable information to address increasingly complex decision needs for managing interconnected human and natural Earth systems and rapidly responding to natural hazards as they arise. 
Actionable information can be defined as efficient delivery of data and information tailored to stakeholder needs and assembled to facilitate decision-making. Delivering actionable information requires a thorough understanding of your stakeholders: who they are, what decisions they make, what science can inform their decisions, and when, how, and where the science needs to be delivered.

The intersection of these three components comprises the overarching goal of the USGS EarthMAP vision: "By 2030, the USGS aims to deliver well integrated observations and predictions of the future state of natural systems - water, ecosystems, energy, minerals, hazards - at regional and national scales, working primarily with federal, state, tribal, and academic partners to develop and operate the capability" (U.S. Geological Survey, 2021).

Providing more integrated Earth systems science and actionable information to decision makers, stakeholders, and the public and from local to national scales requires a better understanding of the depth and distribution of expertise across the USGS, information on the prevalence of collaboration among USGS scientists, and information on existing interdisciplinary activities. Identification of USGS capacities can provide a snapshot of existing investment in the mission areas, help identify related skillsets and specialized expertise, and support strategic planning for workforce recruiting and training to meet our 21 st-century science goals and lead to increased integration of our scientific efforts. To gather more information on the capacity of the USGS to deliver on this vision, two teams were launched in 2020: the EarthMAP Capacity Assessment Team (CAT) and Use-Case Development Team. This report focuses on CAT efforts to gather information on existing Bureau capacity to support the goals of the USGS 21st century science strategy (U.S. Geological Survey, 2021) and EarthMAP vision.

\section{Earth Monitoring, Analysis, and Prediction Capacity Assessment Team Charge}

Upon its formation, the CAT was charged with three main objectives: (1) to conduct a Bureau-wide survey that would provide a snapshot of existing USGS expertise and activities that can support the EarthMAP vision for integrated and predictive science to support decision making, (2) to develop a strategy and proof-of-concept for a continuously updated EarthMAP-supportive capacity assessment capability, and (3) to document lessons learned to inform future capacity assessment efforts. In contrast with other more targeted EarthMAP activities, the capacity assessment survey was to be designed to receive input from anyone at any level within the USGS with an interest in sharing perspectives and to reach scientific and technical staff as broadly as possible across all USGS mission areas and regions.

For practical purposes, we defined capacity as the ability to meet critical natural resource/Earth systems-related decisions effectively and timely. We further defined the components that combine to represent capacity as capabilities (USGS employees and their associated skill sets, technical and scientific expertise, and experience conducting integrated science projects) and tools and technologies (the data collection innovations, models, information/computing technologies, cyberinfrastructure, decision support, and science communication solutions) necessary to enable EarthMAP goals. In the process of developing the EarthMAP vision, Grand Challenge workshop participants identified specific research foci, data collection and integration technologies and processes, advanced analytic and modeling skills and techniques, information delivery approaches, and stakeholder engagement strategies needed to support EarthMAP goals (Jenni and others, 2017). The CAT relied heavily on the Jenni and others (2017) documentation of needed scientific and technical capabilities, tools, and technologies in designing the EarthMAP capacity assessment.

\section{Understanding capacity, capabilities, and tools to enable the EarthMAP approach and goals}

Capacity: The tools and capability to meet critical natural resource/Earth-systems related decision needs effectively and at the speed of decisions.

Capabilities: Experience and knowledge to use and integrate innovative approaches for data collection, analysis, modeling, and targeted information delivery.

Tools: Data collection innovations, models, information/computing technologies, cyberinfrastructure, decision support, and science communication solutions.

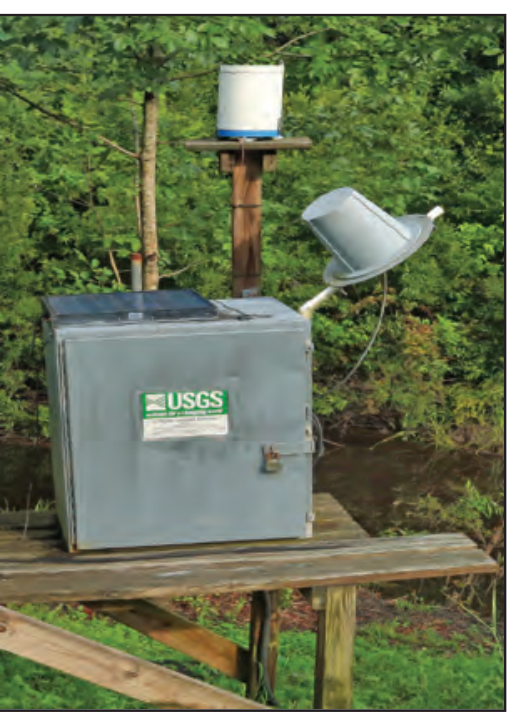

Photograph taken by Alan Cressler, U.S. Geological Survey 
To meet the CAT charge, we first conducted a survey of USGS scientists and technicians to reveal the depth of technical and scientific expertise in implementing data collection and integration tools and processes, modeling approaches, critical Earth systems and decision science capabilities, and stakeholder engagement and information delivery. These elements had been identified as essential for supporting one or more of the three major foundational EarthMAP components (fig. 1). Second, we investigated how survey data could be augmented with additional data from USGS enterprise information systems to aid in analysis and reporting. Third, we examined how some of this information could become part of an interconnected system and developed a software-based method for assembling the various information sources together and providing visualizations that represent connectivity among individuals, their creative works, and their professional networks. Lastly, we developed scenarios to demonstrate how this information can be useful in routine examination of our capacity to address specific planning and decision needs. These scenarios demonstrate that the power of capacity information lies not just in the ability to connect individuals with needed expertise and technology applications, but also in the ability to identify combinations of expertise and technology applications that are needed to address integrated aspects of a given strategic planning or decision need. Example scenarios are included throughout this report to demonstrate how survey results can be used to address specific needs, topics, and questions and aid strategic planning and project development.

\section{Methods}

\section{Survey Development and Deployment}

Development of survey content was guided by the "Grand Challenges" workshop report (Jenni and others, 2017), the foundational EarthMAP vision illustrated on figure 1, and identification of expertise in the USGS science and information delivery framework illustrated on figure 2 . Additional criteria included ensuring the survey instrument and its text was technically sound (for example, form was easy to use, responses were easily collected with a format applicable for analysis, and survey presentation was without notable flaws).

Development of the final survey was an iterative process and comprised three sets of testing, refinement, and revisions to improve usability and the value of resulting information. Two rounds of internal testing were followed by an experimental survey deployment to select external groups identified by CAT members; feedback from users and input from experienced survey design experts led to adjustments in length, the specificity of questions, the content of listed options in closed-ended questions, the addition of "other" narrative response options for closed-ended questions, and more open-ended questions.

The final survey contained 44 questions, which are detailed in appendix 1 . The survey began with an introductory portion focused on general capacity assessment, followed by three sections targeting capacities that parallel the foundational components of EarthMAP: (1) data and information integration, (2) integrated predictive science, and (3) actionable information. The survey was deployed USGS-wide on October 13, 2020. Capacity Assessment Team members, representing all USGS regions (except for the Alaska Region, U.S. Department of the Interior [USDOI] Region 11), advocated for widespread survey participation. The survey was promoted through the EarthMAP Microsoft Teams site and by USGS leadership for the Community for Data Integration (CDI), the Risk Community of Practice (CoP), and the Office of the Associate Chief Information Officer.

\section{Survey Results Augmentation}

Recognizing that the survey only provides a high-level snapshot of USGS capacities in the three foundational areas, the CAT combined survey results with information extracted from USGS enterprise information systems. In reviewing survey responses, it was evident further information about respondents would increase the value of survey results and interpretation. Publicly available USGS sources, including Staff Profiles (https://www.usgs.gov/connect/staff-profiles), the Science Data Catalog (https://data.usgs.gov/), and the ScienceBase Directory (https://www.sciencebase.gov/directory/) were used to augment the survey results with expertise terms, subject matters addressed in data releases, and organizational context information, respectively.

\section{Dynamically Updated Capacity Information Proof-of-Concept}

Personnel expertise and skills and institutional scientific capabilities are constantly changing as staffing changes, skills are learned, new methods are developed, and new tools and equipment are brought online. Although periodic surveys and polls of staff and organizations might be needed to fill important gaps, there is significant value to the organization if information on USGS capabilities could be captured more systematically and applied effectively in capacity assessment and science planning. 


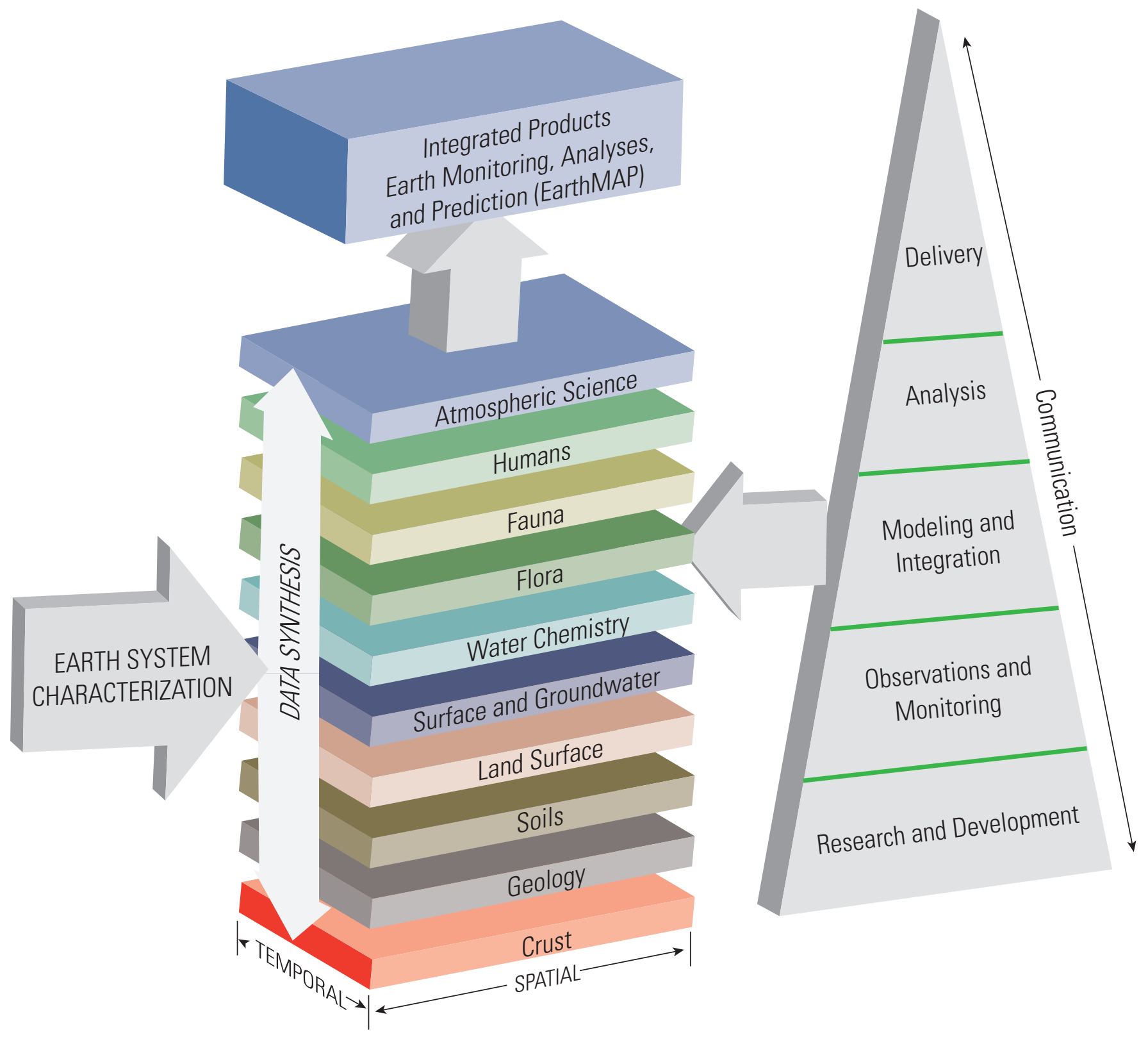

Figure 2. The Earth Monitoring, Analysis, and Prediction (EarthMAP) science and information delivery framework that integrates traditional scientific disciplines and the full portfolio of U.S. Geological Survey science activities: research, monitoring, modeling, analyses, and information delivery (modified from Jenni and others, 2017).

In addition to augmenting the survey data described earlier, the CAT assessed the current ability to use existing enterprise information systems to support capacity assessment. We developed a proof-of-concept of the cyberinfrastructure needed to assemble data from various information sources to more thoroughly characterize scientific capabilities, products, and associations. Appendix 5 provides a more detailed description of methods and findings as well as references to available software.

\section{Survey Analysis}

Survey results were summarized and analyzed using a combination of quantitative and qualitative approaches. Survey questions and results summaries are detailed in appendix 1 and in a corresponding data release (Nelson and others, 2021). 


\section{Quantitative Analysis}

The CAT generated simple quantitative summarizations for closed-ended questions (those in which respondents selected from a list of options) and for some respondent characteristics drawn from augmented data (such as position title, region, and mission area affiliation). These summarizations included questions that asked respondents to rate their level of experience in various science disciplines and select data collection and processing technologies, as well as questions about use of data analytics, predictive modeling, information delivery and stakeholder engagement approaches. Many closed-ended questions allowed users to enter additional skills or activities that they felt should be included in the list provided. Where appropriate, these optional additional responses were qualitatively summarized.

Total staff numbers and position titles for respondents were queried from the USGS Federal Personnel Payroll System (FPPS). The CAT assigned position titles according to the "Position Title" field in the USGS FPPS. Some interpretation of titles was required to group similar titles into a general category. For example, a job description was sometimes split between multiple science-related titles. Where this occurred, we used the organizational description field to further qualify what science-related area best suited that position. For example, if a chemist sits in a Water Science Center, they were added to the "Hydrology" tally, and a chemist at an Ecosystem Science Center was added to the "Biology/Ecology" tally. Where the survey results allowed for counts of individuals with differing levels of expertise (that is, "no experience," "novice," "intermediate," or "advanced"), responses were divided into quantiles to discern topic areas of greatest and least expertise and to better understand the distribution of expertise levels across a given topic area.

\section{Qualitative Analysis}

For select narrative text questions, CAT members developed interpretive summaries of responses using expert judgment and familiarity with EarthMAP priorities to highlight information of particular relevance to EarthMAP goals. All narrative responses to each question were read and any common themes that emerged from the data were further explored using targeted keyword searches and mining of text-field content. For some questions, the themes were further grouped into data classes specific to the narrative question. Although this manual classification approach was the chosen method to analyze narrative question responses, automated methods of analysis also were considered but yielded inconclusive results and are not included herein.

\section{Scenario Analysis}

The survey was designed not just to solicit information on expertise in a single discipline or with a particular technology or modeling approach, but also to allow for a user's investigation of combinations of expertise and activities with multiple characteristics supportive of EarthMAP goals. Depending on a user's interest, different combinations of survey and augmented data could be analyzed. To demonstrate how survey and enterprise ("augmented") data can support strategic planning and project development, the CAT developed several question-driven scenarios to test whether and how the capacity assessment results could be used to identify individuals and activities that can contribute to predefined needs. Scenarios represent realistic questions that can be asked of the augmented survey database to explore specific capabilities, activities, and tools to meet a specific capacity need. In these scenarios, results from individual question responses and keyword searches were analyzed in a logical order to narrow in on a smaller set of respondents demonstrating a higher likelihood of having the necessary experience and skills to address the question of interest. It is important to note that the order in which these queries are constructed has a significant impact on the outcome; the query must be carefully constructed to be consistent with the predefined question and need.

\section{Data Management}

Anonymized survey responses, as well as the Python code used to produce summary figures and scenarios, are published in an accompanying data release (Nelson and others, 2021). It was also important that the analytics used to summarize the survey results and question-driven scenarios previously described were reproducible and systematic. To support this consideration, the summaries and scenarios were scripted using Python and are included in Nelson and others (2021) as Jupyter (https://jupyter.org/) notebooks. 


\section{Overview of Results}

\section{Survey Respondent Characteristics: Region, Mission, and Discipline Distribution}

The survey received 1,035 responses, representing approximately 13 percent of all USGS staff with a scientific or technical job title. All USGS mission areas and regions were represented in survey results, although to varying degrees (fig. 3). These differences in representation could be due in part to differences in size among the units, or could represent the degree to which awareness of the survey reached scientific
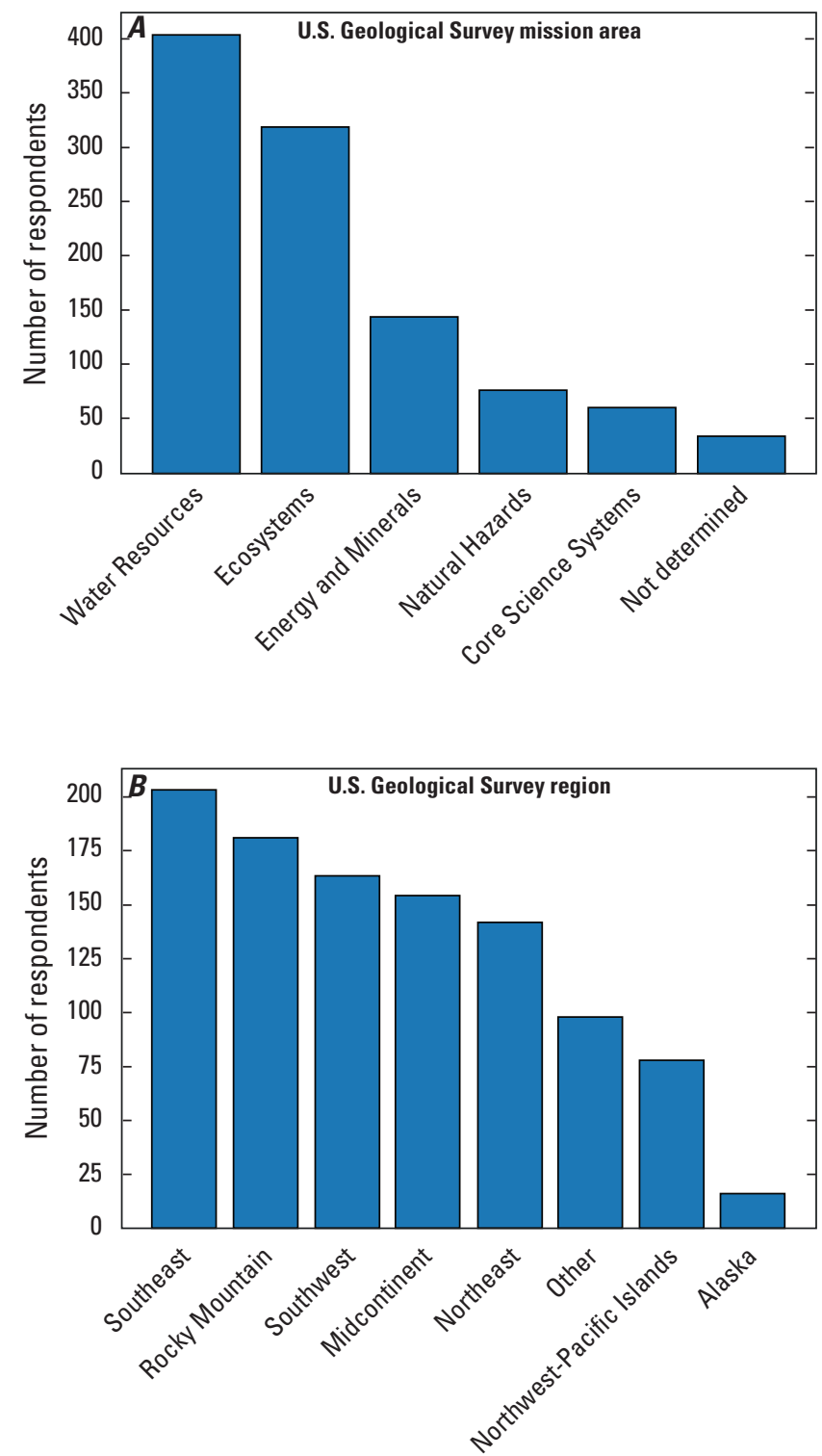

Figure 3. Survey response by $A$, U.S. Geological Survey mission area; and $B$, region. and technical staff within each mission area and region. Of the respondents, 74 percent held a science-focused position title, representing 314 Research Grade Evaluation (RGE) positions and 455 non-Research Grade Evaluation (RGE) science positions. The remainder had position titles in information technology, computer science, management, administrative, or other fields (contractors, volunteers, emeritus, and unknown). Table 1 shows the representation of respondents across general science and technical disciplines.

Position titles do not always represent the disciplinary focus of individuals. To gain a better understanding of the activities in which USGS staff are engaged, the capacity assessment survey asked respondents to select one or more areas of focus across Earth systems disciplines and the research-to-information delivery continuum described in Jenni and others (2017) and illustrated in figure 2. Atmospheric science was the least reported subject area (fig. 4). In contrast, water science was the most-represented discipline, with 51 percent of respondents reporting a focus on surface water, groundwater, or water chemistry. Only about 29 percent of respondents selected a single discipline as their focus, with the remainder selecting anywhere from 2 ( $\mathrm{n}=304 ; 29$ percent) to $10(n=1$; less than 1 percent) disciplines. This information illustrates the degree to which USGS is already well poised to tackle issues requiring integrative approaches.

Respondents were invited to write in additional focal areas that they considered missing from this characterization of Earth system science. Most write-in responses represented sub-disciplines of the general categories listed, but many also identified inherently interdisciplinary fields, such as place-based (for example, barrier islands, coasts), event-based (for example, earthquakes, fire), and process-based study areas (for example, biogeochemistry, carbon sequestration). Respondents were invited to relate their work to a set of complex societal challenges (grand challenges) identified by Jenni and others (2017; table 2).

Table 1. Survey respondents by discipline of position title.

\begin{tabular}{lccc}
\hline \multicolumn{1}{c}{ Discipline-related title } & $\begin{array}{c}\text { Number of } \\
\text { respondents }\end{array}$ & $\begin{array}{c}\text { Total } \\
\text { staff }\end{array}$ & $\begin{array}{c}\text { Respondents as a } \\
\text { percent of total staff }\end{array}$ \\
\hline Hydrology & 315 & 2,540 & 12 \\
Biology/Ecology & 250 & 1,346 & 19 \\
Geology & 166 & 726 & 23 \\
Physical Science & 92 & 577 & 16 \\
Geography & 57 & 350 & 16 \\
Social Science/Mathematics & 25 & 80 & 31 \\
Oceanography & 13 & 54 & 24 \\
Space Science & 1 & 4 & 25 \\
Information Management & 63 & 629 & 10 \\
$\quad$ Technology (IMT) & & & \\
Other & 53 & 1,648 & 3 \\
\hline
\end{tabular}




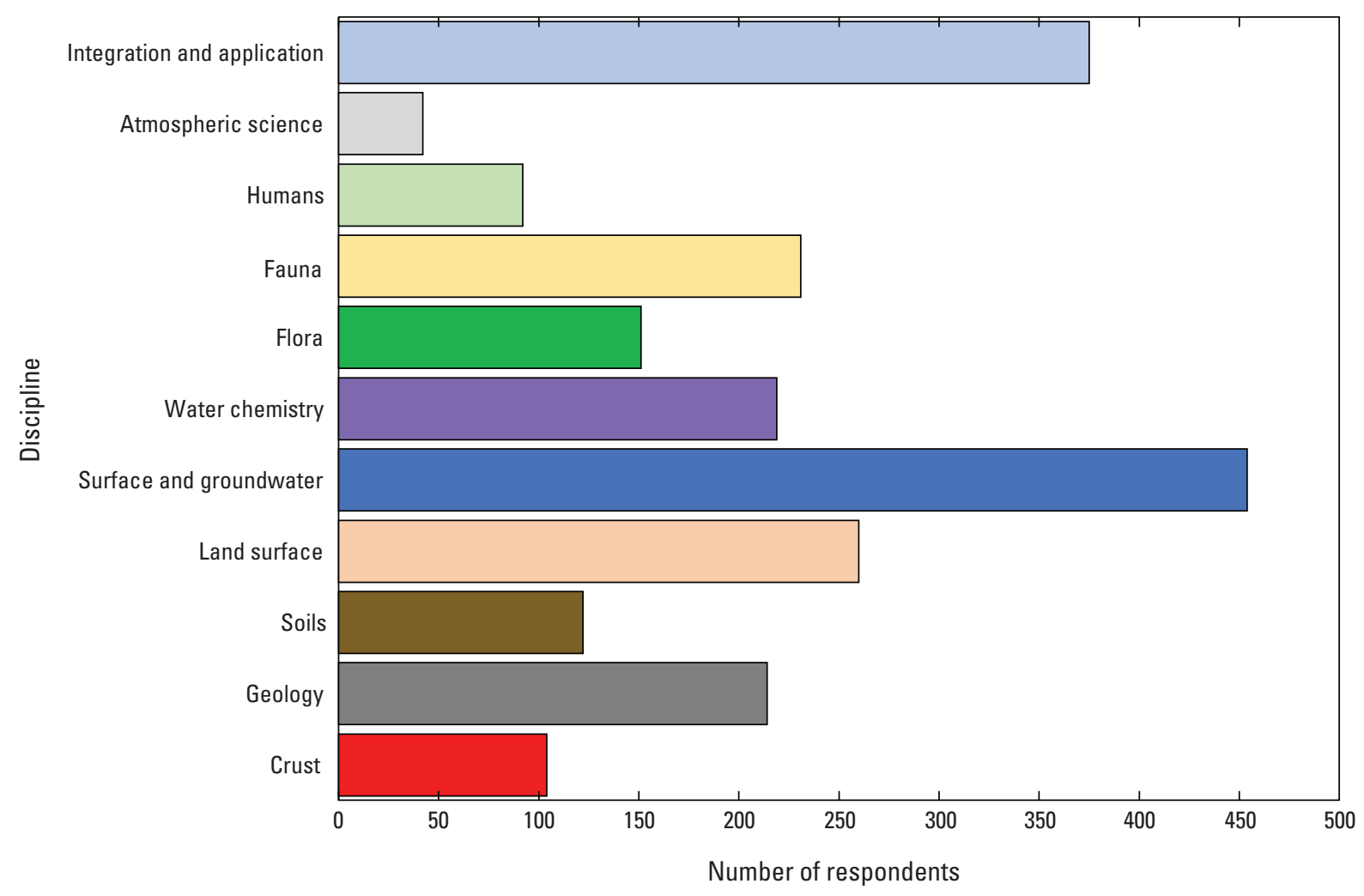

Figure 4. Distribution of respondents across U.S. Geological Survey Earth systems science disciplines, corresponding to those described in Jenni and others (2017) and shown in figure 2.

Table 2. Number of respondents who have been involved in projects that provide actionable information to stakeholders on one or more of a select set of grand challenge science needs.

\begin{tabular}{|c|c|}
\hline Grand challenge need & $\begin{array}{l}\text { Number (and percentage) } \\
\text { of respondents }\end{array}$ \\
\hline $\begin{array}{l}\text { Projections of the consequences and tradeoffs of alternative management scenarios, with explicit consideration of major natural } \\
\text { and anthropogenic drivers of change, their interactions, and cascading effects. }\end{array}$ & $352(34)$ \\
\hline Information to facilitate the mitigation of natural hazards. & $326(31)$ \\
\hline Development of significant Earth systems or natural resource change indicators that can be used to prompt analysis and actions. & $229(22)$ \\
\hline $\begin{array}{l}\text { Information on the effects, consequences, costs, and tradeoffs of natural resource extraction and use from a multi-resource } \\
\text { perspective. }\end{array}$ & $226(22)$ \\
\hline Information to provide early warning of disruptive events. & $218(21)$ \\
\hline Information to aid recovery after natural disasters. & $172(17)$ \\
\hline
\end{tabular}


Finally, respondents reported whether their work involved data collection and integration $(\mathrm{n}=901 ; 87$ percent), modeling to address complex, systems-level problems $(n=436$; 42 percent), or provided actionable information to decision makers ( $\mathrm{n}=758 ; 73$ percent). Those who worked in any of these areas were asked additional follow-up questions related to their level of experience with select science and technical areas and technologies. They were also invited to provide information on activities and projects in those data integration, modeling, and information delivery topical areas. Highlights from these additional survey questions are summarized.

\section{Reported Skill Levels in Identified Scientific and Technical Areas}

Numerous skillsets have been identified as critical for advancing EarthMAP goals to modernize the conduct of science and delivery of information. Some of these skills could advance USGS capabilities related to prediction within any science discipline; some could improve our ability to deliver actionable information effectively at the scale and speed of decisions; and some are technical support functions critical to both of these goals.

The following five research skills ranked in the highest quartile of the "advanced" practitioner category: (1) interagency collaboration, (2) data visualization, (3) Earth systems structure and function, (4) stakeholder engagement, and (5) reducing uncertainty in management decisions (fig. 5). These are analysis and information delivery specialties that have historically been integral components of USGS science for decision support. In contrast, the following skills fell into the lowest quartile for "advanced" expertise: economics/ socioeconomics, operational forecasting, cloud computing and high-performance computing (HPC), decision analysis, user experience/design skills, and policy analysis. Of these, economics/socioeconomics and operational forecasting also were in the lowest quartile of "intermediate" and "novice" expertise classes and were the two most frequently reported "No Experience" skills. Cloud/HPC had a similarly small pool of "intermediate" practitioners but rose to the 3rd quartile of the "novice" category. Although decision analysis had among the fewest advanced and intermediate practitioners, it had the second largest pool of "novice" expertise ( $n=330$; 32 percent). The importance of incorporating decision science, socioeconomics, and policy analysis as components of an integrated Earth science modeling program is increasingly recognized. The results of this survey indicated that the adoption of cloud computing and HPC has been limited to date, but it is recognized as a high priority for EarthMAP and 21 st century science; investments are currently underway to grow this USGS capacity. Similarly, the desire for operational forecasting capability beyond fields that have traditionally focused on near real-time information (such as weather, flood, and water availability forecasting) continues to increase. Later in the survey, respondents who reported conducting complex systems modeling were further asked if their work contributes to operational ecological forecasting. Those that indicated "yes" described models they have produced that deliver forecasts useful to management decisions. Many of the model descriptions included the ability to compare outcomes under different management regimes and climate change predictions. The topics and needs indicated were broad and have been summarized in appendix 2 .

Respondents who reported working on data and information integration were asked to characterize their level of experience with a set of data technologies that had been identified as priorities for adoption in the "Grand Challenges" report (Jenni and others, 2017; fig. 6). The greatest amount of "advanced" expertise in these technologies is reported for plane- and satellite-based imagery, light detection and ranging (LiDAR), hydroacoustic sensors, and camera trap/snapshot data (including analysis of camera or video data). Deoxyribonucleic acid (DNA) chip technology, biometrics and wearable technology, high throughput toxicity screening, soundscape/audio data, and bioinformatics were the least-represented technologies in the "advanced" category. These same technologies also were among the least represented in the "intermediate" and "novice" skill categories.

The relatively high response rate of those who claimed "no experience" indicates that adoption of these technologies and data processing and integration approaches is not yet widespread. The degree to which providing actionable information requires these approaches depends on the nature of the targeted decisions. Further investigation of this need would be required to determine whether this indication of low adoption currently represents a gap in capacity. However, it is likely that greater adoption would enhance the survey's ability to provide timely information for complex decisions in an increasingly interconnected world.

The USGS workforce utilizes hundreds of data collection and management technologies that were not specifically identified in the survey. These solutions are often developed and deployed to address specific scientific needs related to monitoring, data collection, data analysis/visualization, and data processing/interpretation. Among the respondents who identified themselves as using some type of data collection, processing, or integration technology in their work, nearly 18 percent $(\mathrm{n}=160)$ submitted narrative descriptions of data collection and processing technologies or approaches not specifically listed in the survey. These responses were wide-ranging, but the following themes identified in the narratives were noted: real-time data collection and management technologies, seismic and geophysical technologies for subsurface environments, and system design and other information management technologies. It is worth noting that only two of the narrative responses were related to collection and management technologies for social sciences. 


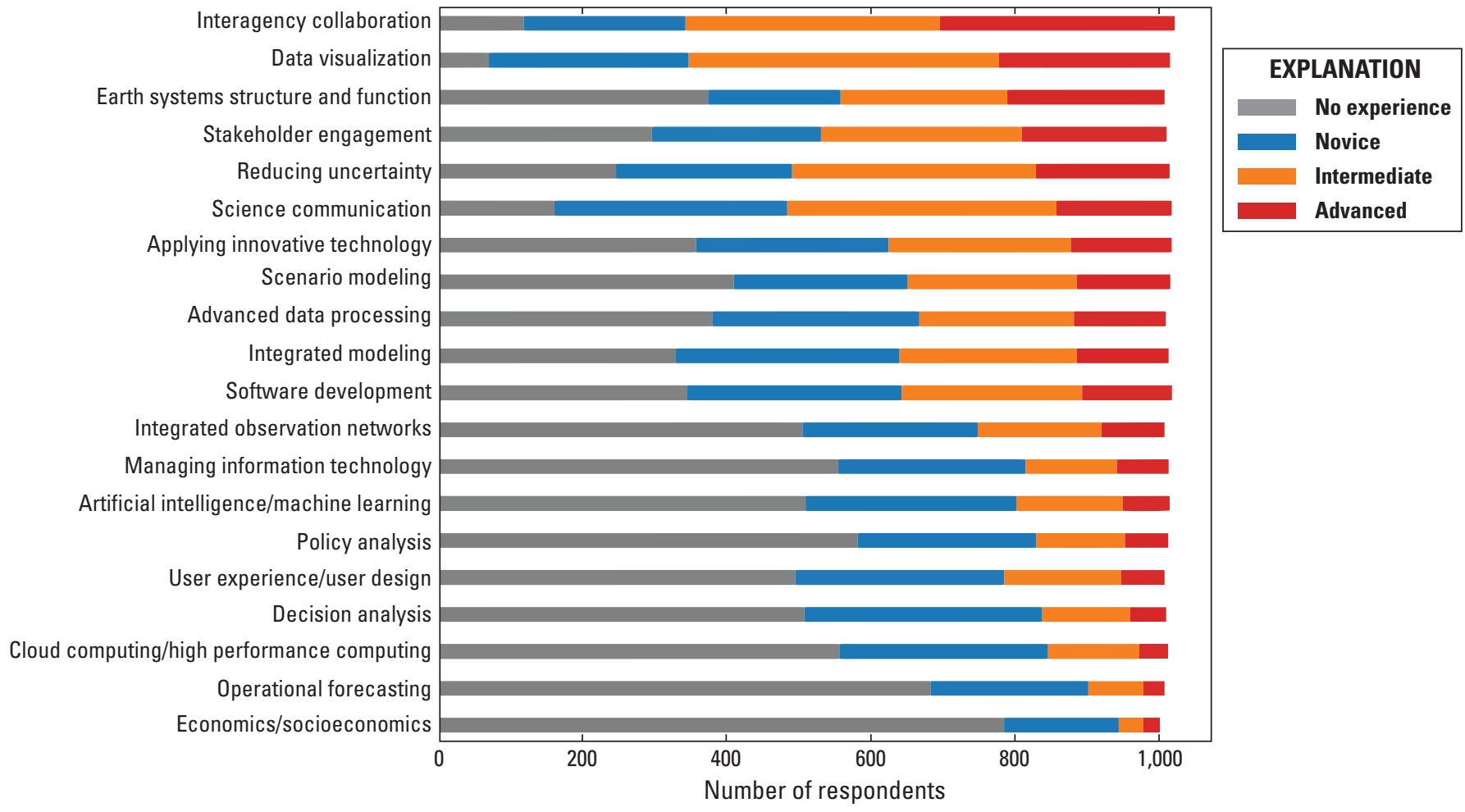

Figure 5. Distribution of reported expertise in listed skills. All respondents were asked to rank their expertise in these skills. Note: survey respondents also were provided an opportunity to identify science and technical skills not listed.

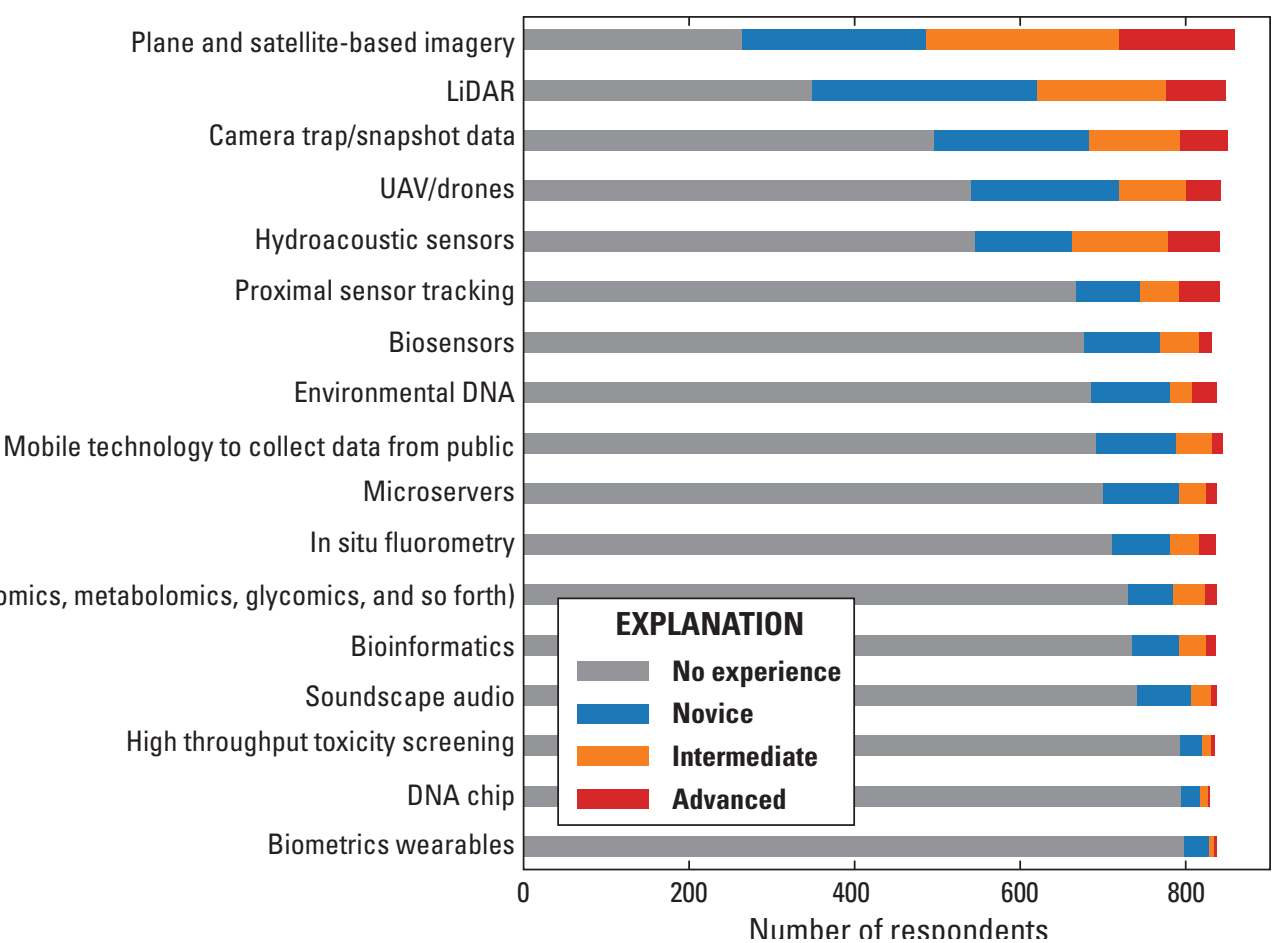

Figure 6. Distribution of reported expertise in a suite of data collection and processing technologies identified in the "Grand Challenges" report (Jenni and others, 2017). 


\section{Example Scenario Finding USGS capacity to support stakeholder needs}

Premise: The National Park Service is designing a beach restoration project at Padre Island, Texas, with multiple stakeholders that will require biophysical data acquisition as well as data integration and assessment of habitat conditions suitable for sea turtle nesting.

Needs: LIDAR and unmanned aerial vehicle (UAV) experience for habitat data acquisition, integration with other partner's datasets, and sea turtle Subject Matter Expertise

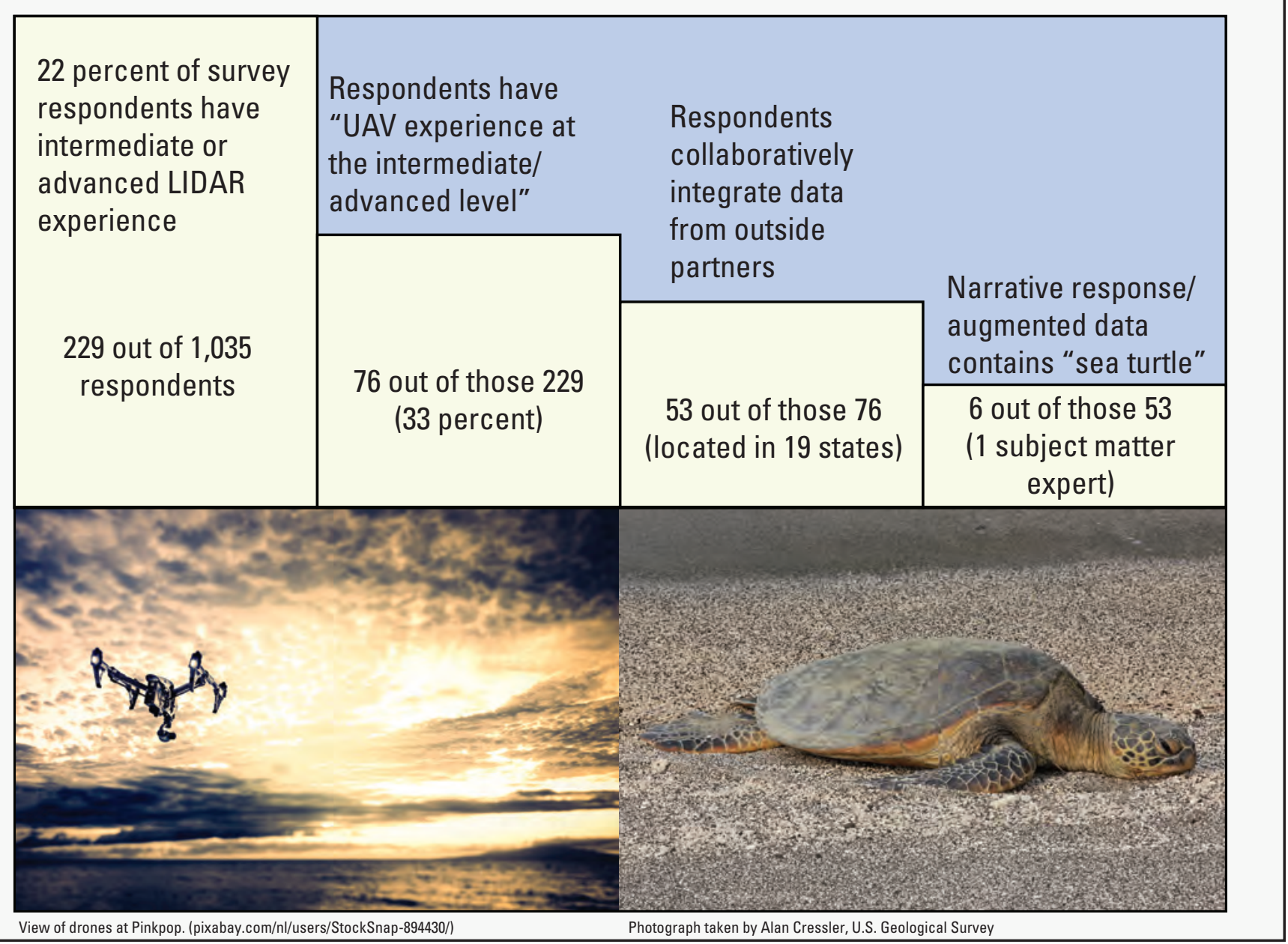

Respondents who reported working on data and information

Characterization of Data Integration, Predictive Modeling, Science Integration, and Information Delivery Activities

\section{Data and Information Integration}

Data collection and usage is ever evolving in a science agency like the USGS. Our tools to store, analyze, visualize, and disseminate new data streams must also evolve. integration ( $\mathrm{n}=901 ; 87$ percent) were asked about their use of nontraditional data sources, engagement in data collection and integration activities considered to be important building blocks for accelerating the generation and delivery of information, and experience with barriers to incorporating new data collection and processing technologies. Results indicate that, overall, use of the listed nontraditional data sources is not widespread. Citizen science was the most reported nontraditional data type, however, even this category was selected by only 19 percent of respondents (fig. 7). 
Reporting of activities that involve integration of non-USGS datasets with USGS data, integrating and synthesizing large and multidisciplinary datasets, and extrapolating monitoring insights across scales were relatively common among respondents (table 3). Application of approaches to reduce data latency and increase the speed of data and prediction verification and delivery was more limited.

As the need for more data over a wider geographic footprint expands, so will the need for the USGS to adopt a more holistic approach to acceptable data inputs. Further investigation of the activities reported here could inform decisions on investment in resources and methods development to accelerate data processing and delivery rates.

Respondents were asked to identify barriers to the implementation of data collection, processing, and integration capacities. Nine barriers were provided as options and several additional barriers were reported as write-in responses (considered as "other," fig. 8).

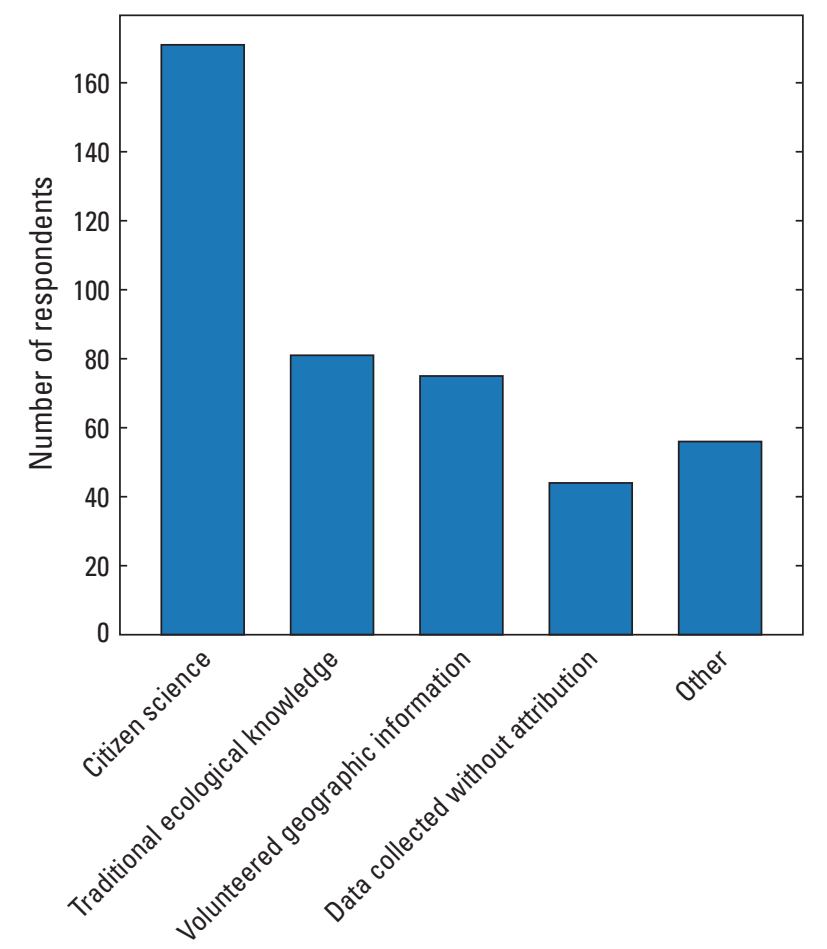

Figure 7. Reported use of nontraditional data sources.
Table 3. Number of respondents reporting a select set of data integration efforts.

[USGS, U.S. Geological Survey; EPA, U.S. Environmental Protection Agency; FEMA, Federal Emergency management Agency; NOAA, National Oceanic and Atmospheric Administration]

\begin{tabular}{|c|c|}
\hline $\begin{array}{l}\text { Have engaged in data collection } \\
\text { and integration work that has: }\end{array}$ & $\begin{array}{l}\text { Number (and } \\
\text { percentage) of } \\
\text { respondents }\end{array}$ \\
\hline $\begin{array}{l}\text { Integrated data with/from outside collaborators into your } \\
\text { projects. }\end{array}$ & $681(66)$ \\
\hline $\begin{array}{l}\text { Enhanced existing or developed new approaches for } \\
\text { integration of large datasets. }\end{array}$ & $497(48)$ \\
\hline $\begin{array}{l}\text { Enhanced the extensibility of research and monitoring } \\
\text { insights across spatial or temporal scales. }\end{array}$ & $440(43)$ \\
\hline Synthesized large multidisciplinary datasets. & $437(42)$ \\
\hline $\begin{array}{l}\text { Developed approaches that increased speed of data } \\
\text { verification, analysis, modeling, and delivery. }\end{array}$ & $278(27)$ \\
\hline Developed processes for reducing data latency. & $139(13)$ \\
\hline Increased speed of prediction verification and delivery. & $110(11)$ \\
\hline Other. & $16(2)$ \\
\hline Not applicable. & $218(21)$ \\
\hline
\end{tabular}

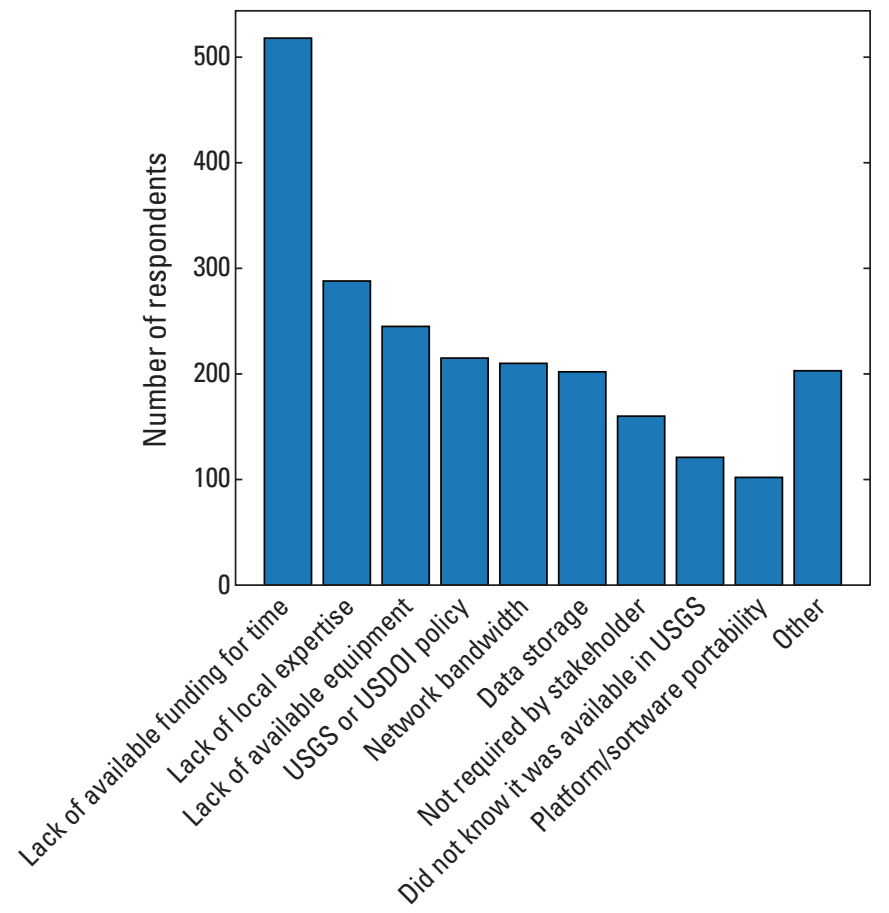

Figure 8. Reported barriers to utilizing new or currently available data collection and processing technologies. Abbreviations: USGS, U.S. Geological Survey; USDOI, U.S. Department of the Interior. 
As might be expected, the most-reported barrier was lack of funding for time. This is a chronic limitation that is difficult to address and often outside the control of USGS managers. More interesting are some other commonly reported barriers that might be addressed with existing resources or with limited additional investment. For example, lack of local expertise and lack of awareness of existing USGS expertise are barriers that can be addressed with improved tools for finding where expertise and resources reside across the organization, as well as improved mechanisms to share those resources. "USGS or USDOI policy" could represent a diverse set of policies that might prevent or limit integration of existing capabilities; for example, respondents specifically identified policies addressing Unmanned Aerial Systems and information technology as barriers. Additional exploration of USGS and USDOI policy barriers could identify whether opportunities exist to change policy barriers, and more communication of strategies for navigating such obstacles could also reduce their negative impact.

\section{Integrated Predictive Science}

Respondents who reported performing integrated predictive science were asked questions to further characterize their modeling work, including questions about predictive modeling approaches, use of uncertainty estimates, spatial and temporal scales, use of operational ecological forecasting, and model scalability. These respondents also were asked questions about the inclusion of social science and economics in their integrated predictive science.

Modeling, particularly integrated and interdisciplinary modeling, is a large part of the EarthMAP vision. The variety of types of models used by respondents showcases the diversity and strength of USGS predictive science expertise. The survey found that 42 percent of respondents $(n=436)$ develop or utilize models for addressing complex systems-level problems and, of those respondents, the majority ( $\mathrm{n}=341 ; 78$ percent) said modeling and integration was a focus of their work. Of the group developing or utilizing models, over half characterized their skills in the preceding "Survey Respondent Characteristics" section as within surface water and groundwater ( $\mathrm{n}=236 ; 54$ percent), but skills in land surface $(\mathrm{n}=150 ; 34$ percent), water chemistry $(\mathrm{n}=122 ; 28$ percent $)$ and fauna $(\mathrm{n}=122 ; 28$ percent) also were highly ranked (note: skill categories were not mutually exclusive).

Nearly half the respondents that commented to the "Integrated Predictive Science" section of the survey indicated that they integrate or "couple" multiple models ( $\mathrm{n}=199$; 46 percent). Other top modeling approaches selected were statistical emulators ( $\mathrm{n}=160 ; 37$ percent), model-data fusion $(\mathrm{n}=154 ; 35$ percent $)$, and artificial intelligence/machine learning ( $\mathrm{n}=150 ; 34$ percent) approaches (fig. 9). Many respondents added other unique modeling types in their

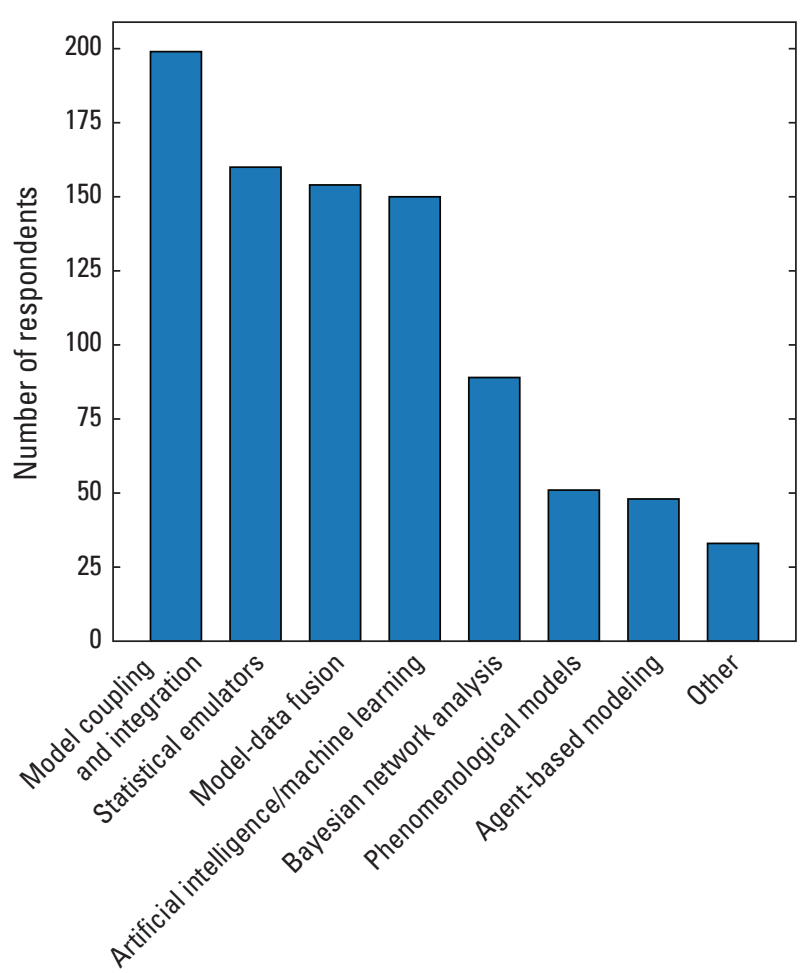

Figure 9. Reported use of the listed predictive modeling approaches.

narrative answers, such as using different Bayesian based models, structural equation modeling, decision network models, simulation models, and state- and transition-models, among others. In addition to the narrative answers given by survey respondents, examples of models developed and used by USGS scientists are available in the beta release of the USGS Model Catalog (data.usgs.gov/modelcatalog).

Most modelers ( $\mathrm{n}=323 ; 74$ percent) reported including uncertainty estimates with at least part of their model components. Approaches to reporting uncertainty included frequentist statistical measures (for example, confidence intervals, $p$-values, root mean square error values, tests for goodness of fit, and so forth), Bayesian approaches (for example, using prior parameter distributions to understand ranges of possible outcomes), and multi-model simulations, sensitivity analysis of model input parameters, and scenario modeling. Sensitivity analysis is employed to determine what model input parameters are most sensitive and how errors in those parameters could propagate into results. Scenario development allows for input of different future climate alternatives or different management strategies, which in turn provides estimates of the range of uncertainty among the resulting different outcomes. Some respondents commented that though parameter or other statistical measures express uncertainty, quantification of the propagation of uncertainty throughout iterative model steps could be difficult to achieve. 
Several examples of how uncertainty estimates were made applicable to decision-making included visualizations of different scenarios, standardized outputs from developed applications, and a dashboard describing uncertainty.

Those who were not applying uncertainty estimates to their predictive modeling expressed lack of experience, lack of funding, and lack of data or that system complexity makes it too difficult to quantify uncertainty. Interestingly, some respondents noted they are adapting to characterizing certainty to decision makers rather than uncertainty: "We have been trying to switch the thinking to "certainty," away from "uncertainty," which can make decision makers and users uneasy."

There was a wide diversity of spatial scales reported by the predictive science section respondents, with most respondents working at the small regional to local scale and

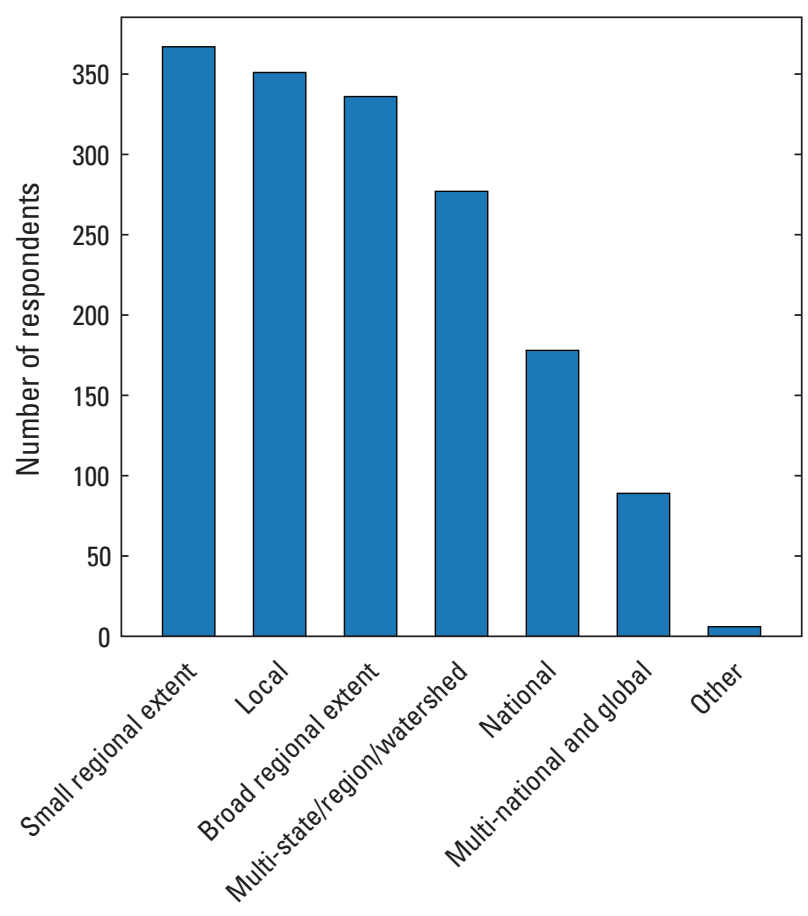

Figure 10. Responses to the survey question "At what spatial scale(s) have you worked?" many working at large regional to national scales (fig. 10). Many respondents (more than 200) focused on temporal scales of seasons to years and decades with fewer (less than 100) working on the category of hours-days-weeks (fig. 11). The scales that USGS scientists tend to work on are usually based on the needs of the individual projects that are funding the studies. About $100(\mathrm{n}=133 ; 31$ percent) modelers stated that the capability to scale their models already exists, whereas a large majority of modelers said that their predictive models could be scaled to other locations or timescales with additional investment (such as identified stakeholder need, additional data, additional model development, or access to new technology). Thus, the capacity to do predictive science at large integrative scales is potentially available with additional investment in model application and data acquisition.

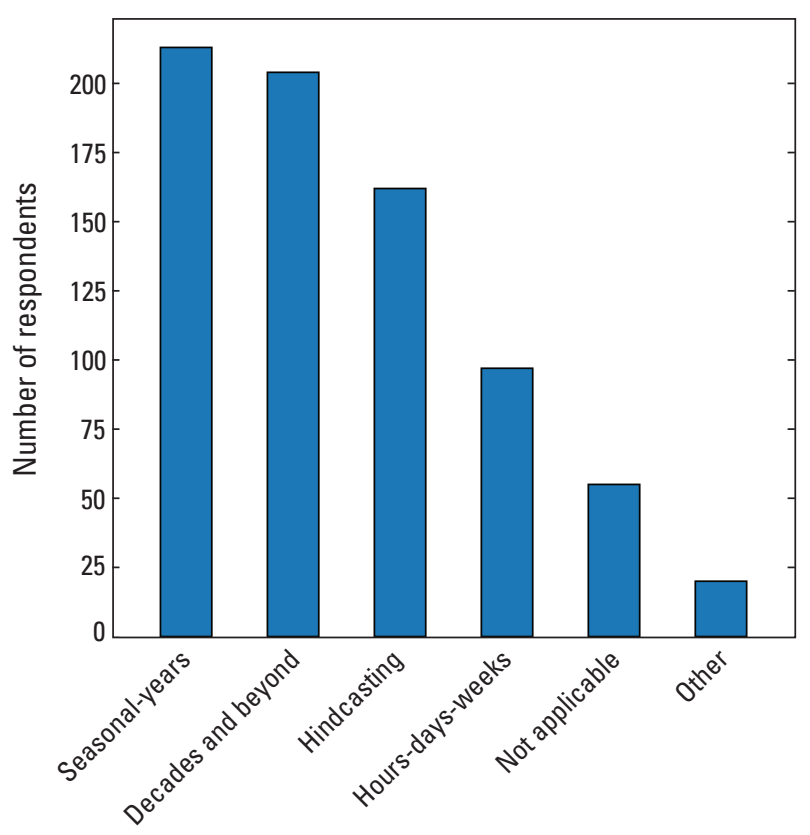

Figure 11. Responses to the survey question "To what extent is prediction currently being used in your temporal analysis?" 
Over half of the predictive science section respondents said they did not integrate either social science or economics into their predictive analysis and modeling $(\mathrm{n}=232$; 53 percent). Of those that did include social science or economics ( $\mathrm{n}=184 ; 42$ percent), the majority $(\mathrm{n}=122$, 66 percent) incorporated these disciplines informally. The reasons given for not including these factors include not being requested by the stakeholder, lack of expertise, and inclusion of social science or economics being outside the scope of the modeling. Several respondents indicated that their predictive models had been incorporated into or supported economic models but with the economic work done by external parties. However, a few respondents expressed the mistaken belief that USGS mandates do not allow them to include social or economic analyses in their work. More respondents indicated they would like to include social and economic sciences and though aware of these capacities within USGS, some respondents indicated not knowing how to establish these within agency partnerships. Opportunities to include these social and economic sciences were described, such as predicting "how the economy might be affected as the ecosystem responded to a fisheries management decision favoring one species over another," or by "incorporating social science (through connections with native communities in Alaska) in science-based studies of permafrost change." Comments regarding informal incorporation of these sciences provide insights of how they are incorporated, such as through incorporation of human land use, resource management practices (for example, fire suppression, livestock grazing, and harvesting practices) and land use change, as well as through estimation of anthropogenic climate effects.

\section{Example Scenario Finding USGS capacity to support coastal climate adaptation}

Premise: The Nation's natural resource managers have an urgent need for information to plan for and mitigate the effects of climate change on coastal ecosystems and human communities.

Needs: Understand USGS science capacity to conduct coastal climate adaptation modeling and to inform conservation and restoration of coastal systems.

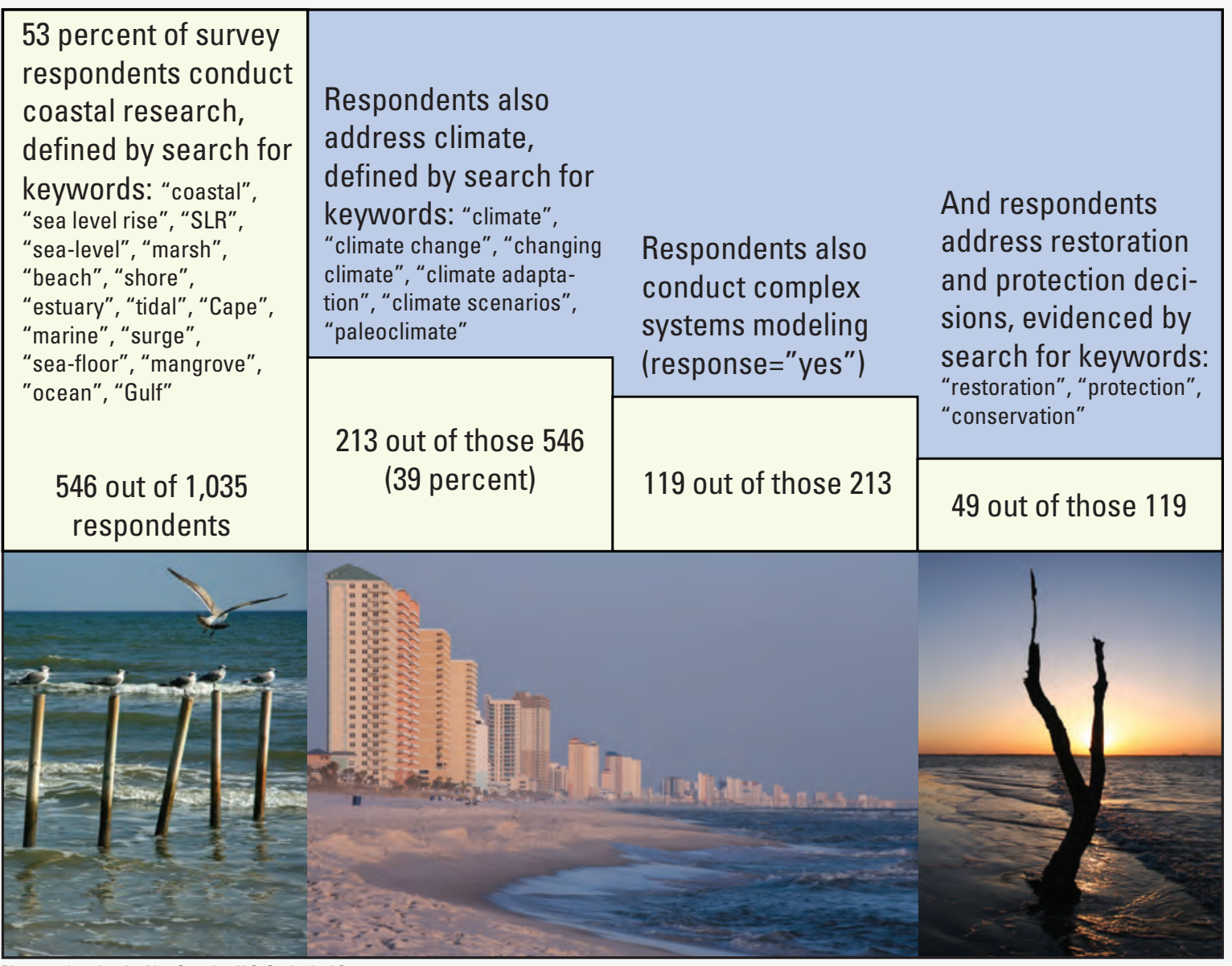

Photographs taken by Alan Cressler, U.S. Geological Survey 


\section{Delivery of Actionable Information}

Respondents who reported providing actionable information to decision makers were asked questions about stakeholders and stakeholder engagement, the involvement of decision science in their work, and the communication approaches used to disseminate their science. The USGS has a long history of working to provide stakeholders with meaningful and useful scientific information, and survey respondents described strong working relationships with our partners on the landscape. In conducting USGS science, 73 percent $(n=758)$ of respondents indicated that they provide actionable information to decision-makers. Of those respondents, 77 percent $(n=581)$ characterized their skills and experience in engaging with stakeholders as either intermediate or advanced. The top stakeholders selected are shown in figure 12 . Only 56 of respondents to this section identified "underserved" communities as one of their stakeholders and even fewer selected "non-English speaking communities."

U.S. Geological Survey science informs a wide variety of stakeholder decisions. Many stakeholder decisions and responsibilities are topically aligned with USGS mission areas, addressing the management of land, water, and associated biological and natural resources, mineral and energy resources, and natural hazards. Most survey responses $(\mathrm{n}=602)$ provided additional descriptions of the types of stakeholder decisions informed and the timescale on which decisions are made. The CAT processed and organized these responses into 24 related types of decisions, or decision classes, based on knowledge of current mission area types of work (fig. 13). The classes are not mutually exclusive.

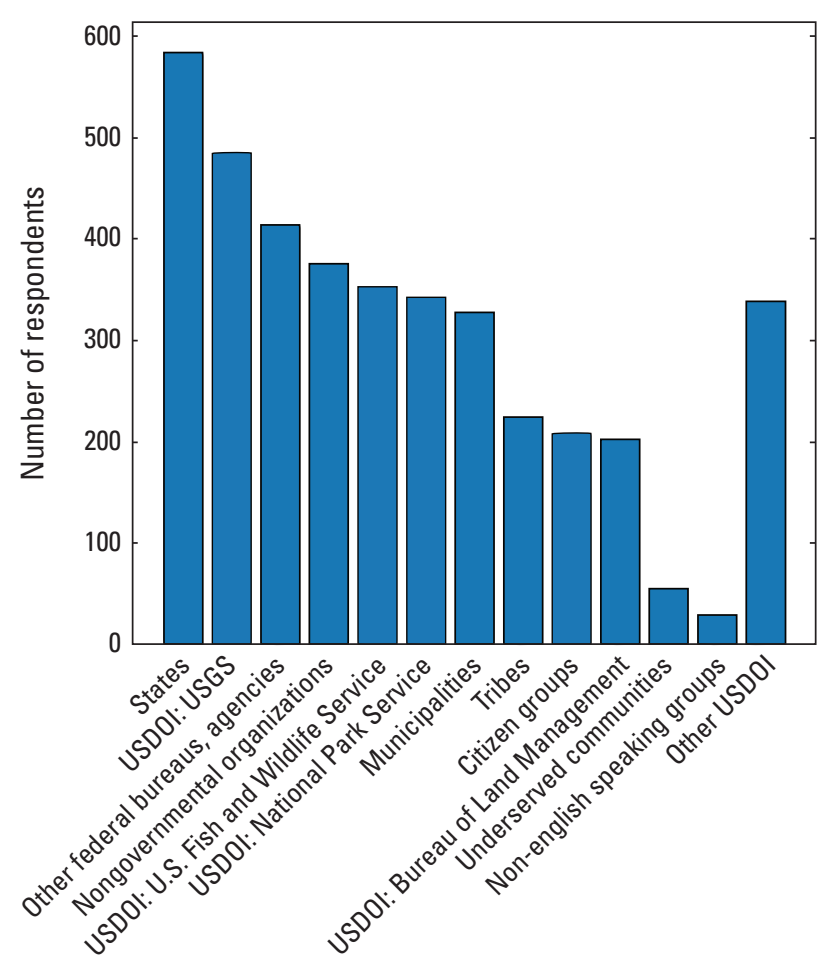

Figure 12. Number of respondents who identified the listed organizations or groups as one of their stakeholders. Abbreviations: USGS, U.S. Geological Survey; USDOI, U.S. Department of the Interior. 


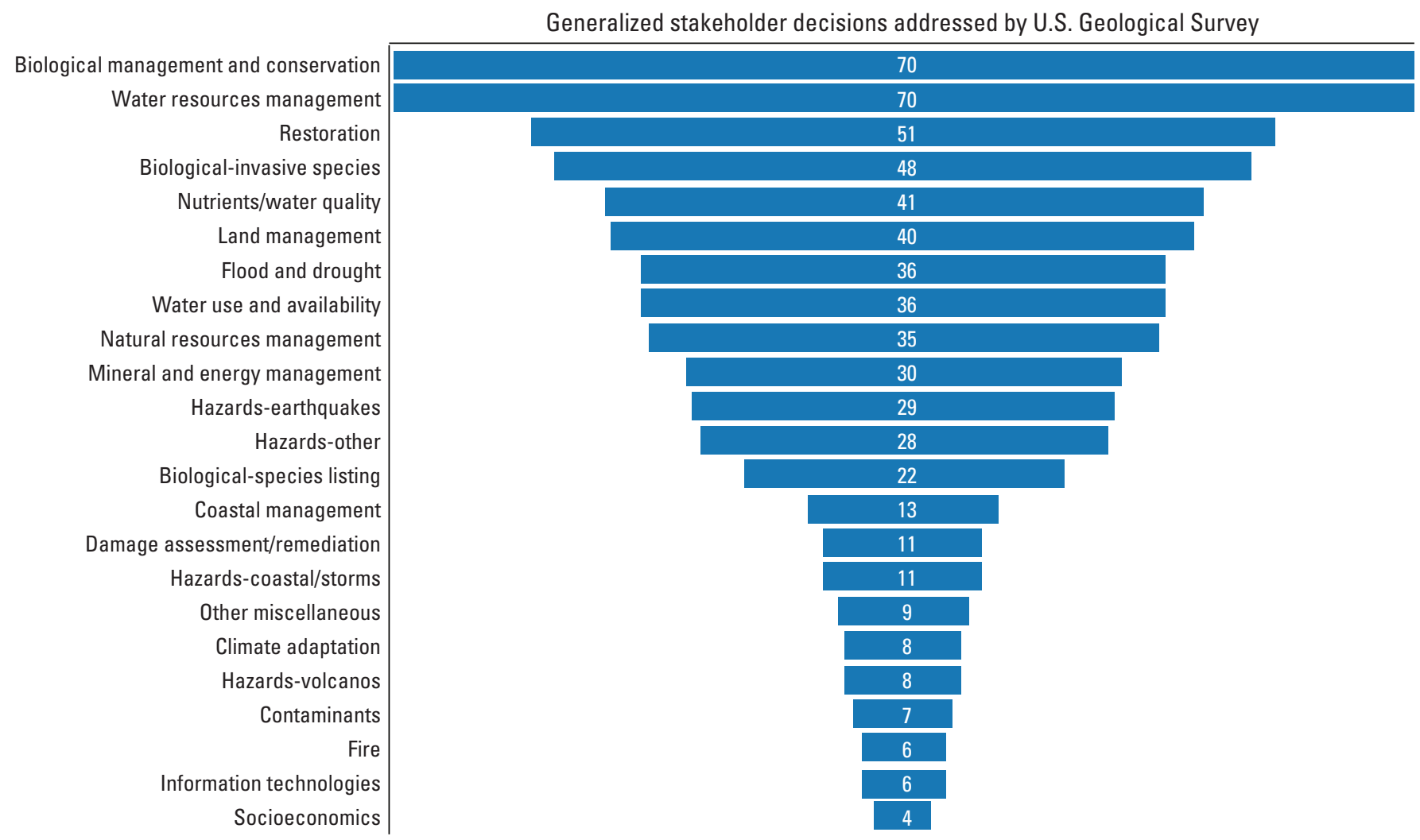

Figure 13. Decision classes for stakeholder decisions addressed by the U.S. Geological Survey.

Survey responses indicated that stakeholders are looking for science to inform decisions on multiple timeframes, from hours to decades and beyond, requiring short-term and long-term data and information. Regardless of mission area, respondents identified seasons-to-years as the most frequent timeframe for decisions that their science informs, followed by "decades and beyond" and hours-days-weeks, respectively. Many respondents who identified informing rapid decisions also reported informing decisions on longer timescales, illustrating the multiscale nature of management decision timeframes. More rapid timeframe decisions tended to fall more frequently into (1) hazard classes associated with earthquakes, volcanos, and other (for example, landslides); (2) flood and drought; and (3) water resource management. The hazards were primarily focused around disaster planning and response; flood and drought were primarily focused around flood warning; and water resource management commonly addressed decisions around freshwater regulation and the operation of control structures.

Survey respondents indicated that conversations, phone calls, workgroups, casual face-to-face meetings, requests for information, local outreach, emails, reliable data streams, and direct briefings foster trust and dialogue and meet stakeholder needs, with the result being collaborative decision making. The greatest number of respondents $(\mathrm{n}=523 ; 50$ percent $)$ who deliver actionable information indicated that stakeholders are involved in their science efforts throughout the life of the project and less than 5 percent $(n=50)$ indicated that they do not interact directly with stakeholders in their work. This movement toward co-production, with engagement early in project design through post-mortem evaluation, allows the USGS to better target the questions stakeholders need addressed and to provide more efficient delivery of data and information tailored to users' needs.

The CAT acknowledges that we cannot determine from the survey how effective these interactions with stakeholders have been. However, incorporation of decision science often is identified as an approach that can improve the effectiveness of problem-solving with stakeholders to achieve desired objectives. Respondents were asked to characterize their skills and experience with decision science and only 44 individuals self-identified as being advanced practitioners of decision science. However, 41 percent of respondents $(n=314)$ in this survey section reported either collaborating with decision scientists or conducting decision science as an aspect of their work (fig. 14). 


\section{Example Scenario Incorporate socioeconomic expertise to improve early warning systems}

Premise: Providing effective early warning systems for hazards or emerging threats is a USGS priority; incorporating socioeconomic analysis and providing effective visualizations can improve communication of risk to the public.

Needs: Identify scientists who have investigated the consequences of existing and emerging threats, and conducted work related to early warning and risk for short-term stakeholder decisions. Among these, identify those who have also considered socioeconomics or used web-based visualizations.

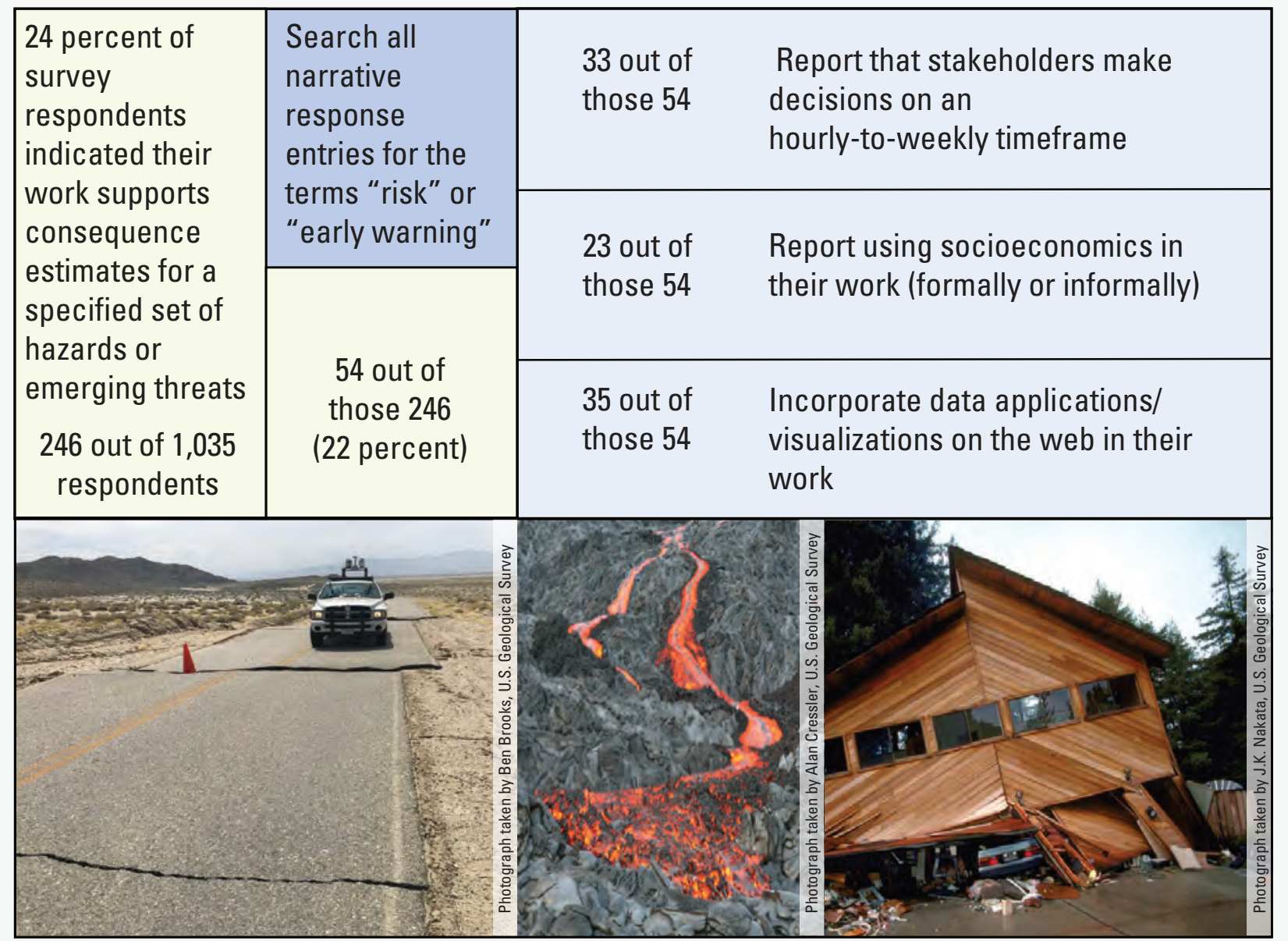




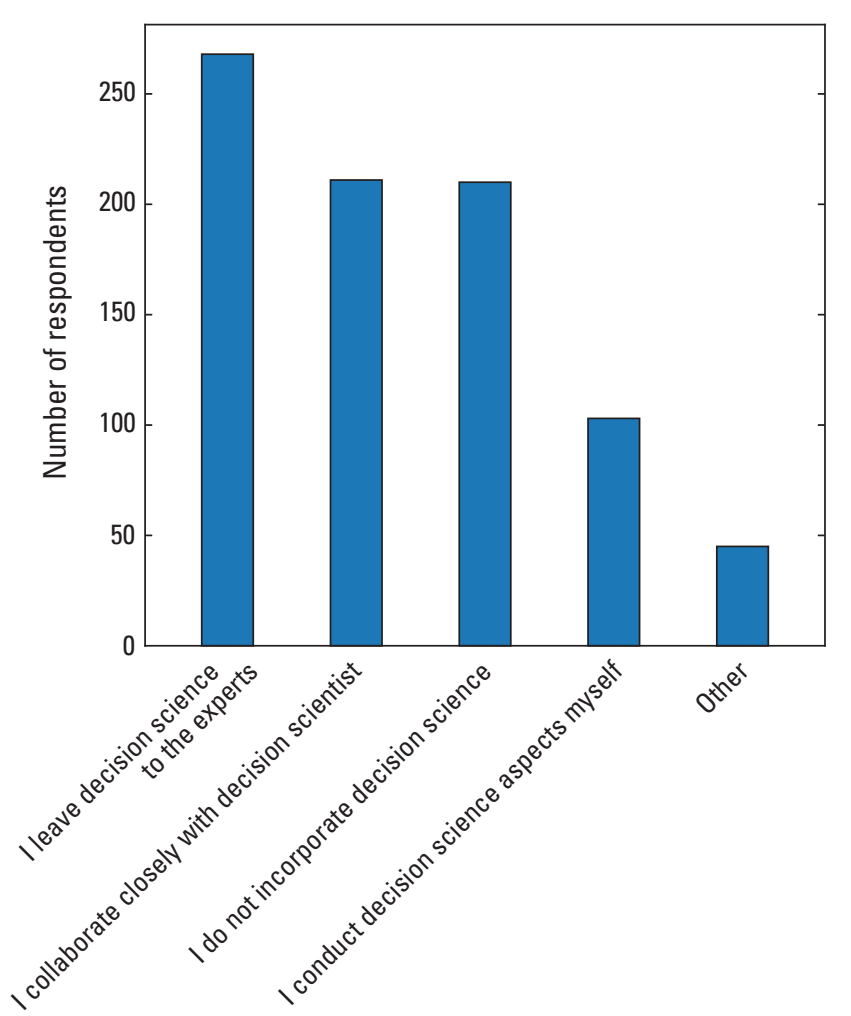

Figure 14. Number of respondents who reported incorporating decision science into their work in one or more of the listed ways.

The value of producing actionable information is highly dependent on effective communication and sharing of our science information with technical and nontechnical stakeholders. U.S. Geological Survey reports (local, national, international) and presentations that are cited by our partnering agencies and used by managers have long been a strong suit of the USGS. Multi-agency co-authored reports synthesizing status and trends are one example in which various agencies are closely involved in producing and delivering information. Respondents cited presentations at professional meetings and workshops, community outreach, and community learning opportunities as collaborative outreach opportunities they use to engage with decisions makers and other scientists, smoothing the way for adaptive management efforts.

The use of web-based platforms and journalistic media were identified as the most prevalent approaches to deliver data and information to non-scientific audiences, followed by social networks and social media (fig. 15). Our survey found that 42 percent $(n=430)$ of respondents deliver data applications and visualizations on the web and the approaches used are quite variable, depending on the audience and need. Reported formats include static, dynamic, and interactive content as illustrated by static summary graphics and reports; storyboards and dashboards that summarize and provide narrative context; computational notebooks; data exploration web applications such as R Shiny (https://shiny.rstudio.com/) and Tableau (https://www.tableau.com/); real-time dynamic products; and interactive data analysis, visualization, and decision-support tools. A list of all the Uniform Resource Locators (URLs) provided by respondents was organized under the identified stakeholder decision classes (fig. 13) and is provided in appendix 3 .

Actionable information has the expectation that we regularly create and deliver science information that stakeholders can actively use. To meet this need, USGS staff have developed real-time dynamic products and interactive data analysis, visualization, and decision-support tools that provide opportunities for customized user queries. The USGS currently provides a diverse suite of real-time dynamic products coupled to volcanic eruptions, earthquakes, landslides, coastal change hazards, evacuations, flooding, rapidly deployed equipment, water resource management, wildfire, species and threshold monitoring, and remote sensing. These products provide critical change notifications to decision makers and the general public, filling operational knowledge, forecast, or risk alert gaps. The USGS also delivers web sites that provide a more comprehensive delivery of information (that is, observational data, models, maps, visualization tools, science translation) to serve technical and nontechnical stakeholders. Examples of these more holistic and interactive sites include, but are not limited to, the Earthquake Hazards Program (https://earthquake.usgs.gov/), Hazard Exposure Reporting and Analytics (HERA; https://www.usgs.gov/apps/hera/), the Coastal Change Hazards Portal (https://marine.usgs.gov/coastalchangehazardsportal/), and the Coastwide Reference Monitoring System (https://www.lacoast.gov/CRMS/).

Permalinks (that is, URLs that will not be deleted or modified) and human readable URLs were identified as important communication tools. A respondent indicated that "human readable URLs effectively become brands so we should treat them with the same care and caution as we do our Identifier or our top-level URL, usgs.gov." Finally, our respondents mentioned that capacities related to software coding and programming, web support, and ecosystem natural capital accounting were not well represented by the survey questions as actionable information.

Although the survey generated a wealth of examples of ongoing USGS stakeholder engagement, science communication, and decision science activities, technical and institutional obstacles to improving stakeholder engagement and delivery of actionable information remain. Once again, most respondents in this section ( $\mathrm{n}=508 ; 88$ percent) identified lack of funding as a barrier to incorporating more stakeholder engagement, decision science, and innovative science communication approaches into their work. The second most reported barrier was lack of expertise (fig. 16). Like described previously, improving collection and availability of information regarding USGS staff expertise and activities could enable sharing of expertise across geographic and organizational boundaries. 


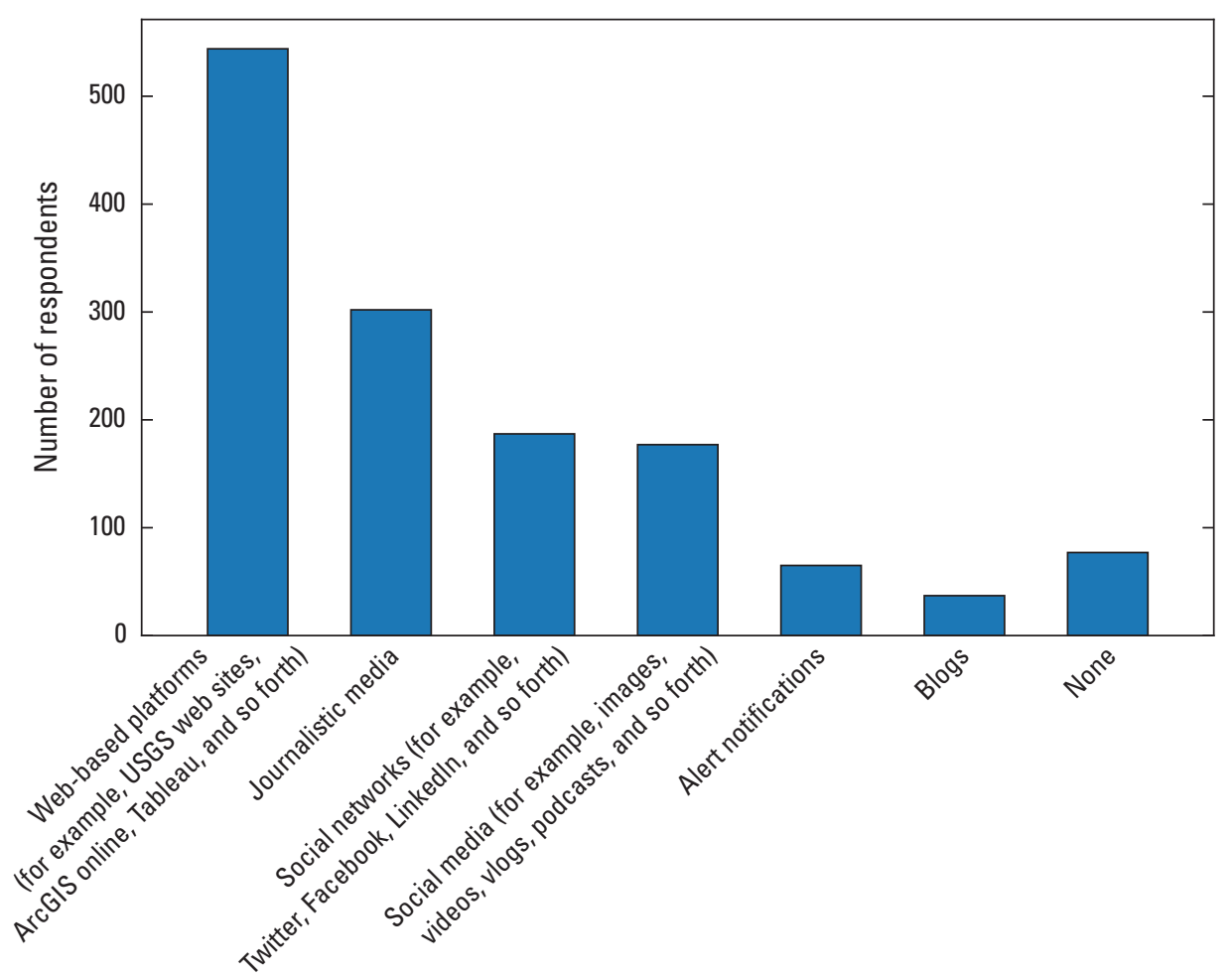

Figure 15. Number of respondents who used the listed science communication approaches for information delivery to non-scientific audiences. Abbreviations: USGS, U.S. Geological Survey.

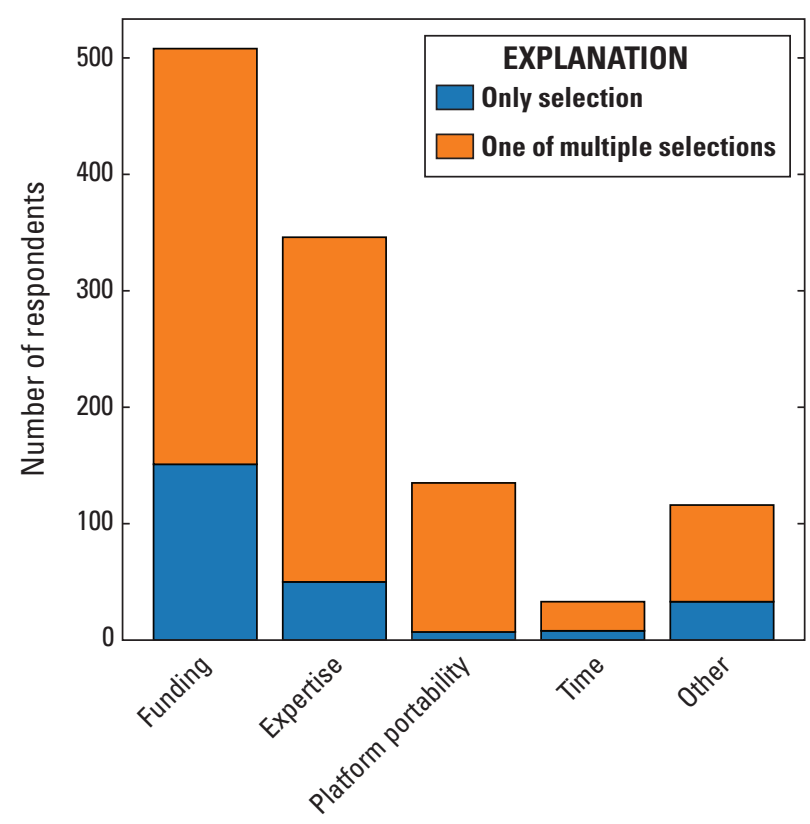

Figure 16. Number of respondents who identified the listed barriers as limiting their ability to incorporate more stakeholder engagement, decision science, and innovative science communication approaches into their work.

\section{Multidisciplinary Science}

Integration of research, modeling, and information delivery activities across traditional disciplines will be essential to achieving EarthMAP goals and provide timely, relevant science now and into the future. To assess current capacity to address multidisciplinary science needs, we asked respondents to report whether they had engaged in multidisciplinary efforts with scientists from multiple mission areas and invited them to provide examples of such projects.

Almost 700 participants reported engaging in multidisciplinary collaborations across mission areas. Of those participants, 31 percent reported collaborating with one additional mission area; the remainder reported collaborating across two or more mission areas. Self-reporting of multidisciplinary activities provided insight into perceptions of what constitutes multidisciplinary work, as well as affirming the multidisciplinary nature of the workforce within individual mission areas.

Over 150 survey respondents provided information on their projects that they considered to be multidisciplinary. To facilitate future analysis, we organized these submissions and added classifiers to indicate the core and integrated mission(s) as well as information on relevant scientific, technical, and information delivery characteristics (appendix 4). 
The project information provided showed a range of perspectives on what constitutes a multidisciplinary project. Examples range from narrow (for example, surface-water hydrology and groundwater hydrology) to broad (for example, ecosystems sciences, socioeconomics, and data management). The science disciplines vary, but the most common links are among hydrology, water quality, and aquatic biology disciplines. Multiple projects related to mineral extraction link energy, minerals hydrology, contaminants, and climate science. Others integrate geology, hazards identification and mitigation, and coastal and marine sciences. In most cases, the links in appendix 4 connecting to project descriptions provide a detailed catalog of integrated science practices and outcomes, and a preliminary assessment adds summary documentation of interdisciplinary links. Overall, these projects provide evidence that (1) the USGS has the capability to address a wide range of interdisciplinary, multiscale issues, either through partnerships within the USGS or with established partners; (2) the USGS already has many projects underway that appear to meet elements of the EarthMAP vision; and (3) the USGS has staff who understand and have experience in the practical aspects of data and science integration. It is evident that integration science is not a generic skill. Expertise in cross-discipline integration is specific to the disciplines and the topics being addressed, and the USGS has staff that can provide leadership in multiple specific types of integrated science efforts.

\section{Communities of Practice}

Communities of Practice are defined as groups of people who share a concern or a passion for something they do and learn how to do it better as they interact regularly (Wenger, 1998). Communities of Practice have proven to be valuable environments for accelerating adoption of innovative approaches and technologies and sharing best practices. About 350 respondents listed participation in CoPs (including workgroups or collaborations) related to data integration, integrated predictive science/modeling, stakeholder engagement, decision science, and innovative science communication. There were many references to established internal USGS CoPs such as the CDI and its collaboration areas. Several Region- and Mission Area-specific groups were identified, focusing on adoption of many of the high priority topics and technologies discussed herein. Some respondents listed CoPs led by other agencies regarding topics for which USGS groups may not be available. Many external consortia were mentioned, as well as place-based restoration and resource management programs and stakeholder groups. As demonstrated by the scenarios included in this report, keyword searches of the survey data (Nelson and others, 2021) are an effective way to identify USGS participation in groups with a focus of interest, be it technical, system specific, or related to engagement with a given stakeholder group.

\section{Dynamically Updated Capacity Assessment Information}

Like noted earlier, the survey results provide a high-level snapshot of USGS capabilities in the context of the survey's questions, which were oriented around capacities in data and information integration, integrative predictive science, and actionable information. The iSAID proof-of-concept described in appendix 5 demonstrates that development of a dynamically updated capacity assessment knowledge graph (Berners-Lee and others, 2001) is feasible and identifies where existing information systems can be improved to enable such a capability. The proof-of-concept is inclusive of all staff and organizational units and includes data, models, instruments, publications, and the overall state of our lines of research. The proof-of-concept also explores the potential to incorporate information from periodic surveys into iSAID, adding value that is not routinely captured by enterprise information systems to the Bureau's capacity knowledge base. This envisioned science capacity information capability would be available for on-demand queries related to new capacity assessment needs as they arise.

\section{Key Findings, Lessons Learned, and Recommendations}

\section{Capacity Assessment Process}

The CAT efforts to develop and assess existing USGS capacity to advance the EarthMAP mission revealed a fundamental challenge for this effort and any effort to assess existing capacity: A considerable amount of thought, time, and effort is required to survey and assess capabilities and tools available to support a given need, yet best results are still likely to provide an incomplete assessment. The likelihood of an incomplete assessment results from a combination of (1) an inherent inability to conduct a complete assessment by a snapshot-in-time Request for Information (RFI; the CAT survey response was considered robust, yet represented only 13 percent of the USGS), which likely will miss critical capabilities and tools and (2) a recognition that determining whether capacity in any type of expertise or technology is "sufficient" is dependent on articulation of a specific problem, question, or stakeholder need that no single, overarching attempt at capacity assessment (and gap analysis) can effectively inform specific strategic science planning decisions. To better meet the frequent need to assess capabilities, tools, products, and projects that address an expressed strategic priority, the CAT proposes the concept of an on-demand capacity assessment framework supported by continuously updated, dynamic information. 
Imagine that in the scenarios provided throughout this report, the first two steps of keyword or expertise searches are completed through queries of everything we already know about what we have and work on without first investing weeks or months in designing and conducting a survey. The results would include all Bureau staff rather than only those who responded to an RFI. More widespread use and frequent updating of professional pages with terms that are part of a controlled vocabulary would improve the quality of query results, which could then combine self-reported expertise with keyword information from creative works and open science forums. Identification and examination of the connections among individuals working in a particular topical area, the facilities and technical infrastructure they access, their projects and associated products, and their professional networks could be generated dynamically. As a result, follow-up manual RFIs would then target a smaller group of individuals who are already known to be active in the area of interest. Because the resulting RFI would be more specific and targeted to fewer people, additional details could be provided on why the information is requested. Improved targeting would result in fewer and more relevant RFIs, likely leading to increased response rates. Potential workshop or project participants could be identified with greater confidence that individuals across the Bureau with the relevant knowledge have been included, rather than just those who are already well established or well connected in their fields. Additionally, input from survey design experts is likely to improve the usefulness of survey responses. Finally, and critically, new information collected by manual RFIs could be captured and added to the appropriate information systems. The Bureau's capacity knowledge would grow over time, iteratively improving the ability to access, leverage, and synthesize existing capabilities and assets, as well as to identify and fill critical gaps (fig. 17).

Although USGS existing enterprise information systems currently lack the structure, cross-system consistency, interoperability, and stability to be fully reliable for more than their singular focused purposes, there are reasonable steps to be taken in the near term to improve the utility of information gathered on expertise and project capacity and to improve the consistency and completeness of information and the ability of USGS systems to share that information. Over time, some of the same innovative analytical tools and data mining approaches necessary to deliver on the EarthMAP vision can be utilized to evolve the ability to integrate and analyze information on USGS staff and their associated technical and scientific expertise, data collection innovations, models, decision support, and science communication solutions necessary to enable EarthMAP (or other) goals.

The ability to search and characterize this information would make future assessments of capacity faster, more complete, more efficient, and more targeted. This approach would better meet strategic planning needs while reducing "data call fatigue" of staff, so that when asked for information, responses are likely to be greater in number and of higher quality. Thus, a continuously updated, dynamic capability would accelerate USGS advancement toward an integrated, predictive Earth systems science capability that provides actionable information to decision makers, stakeholders, and the public from local to national scales.

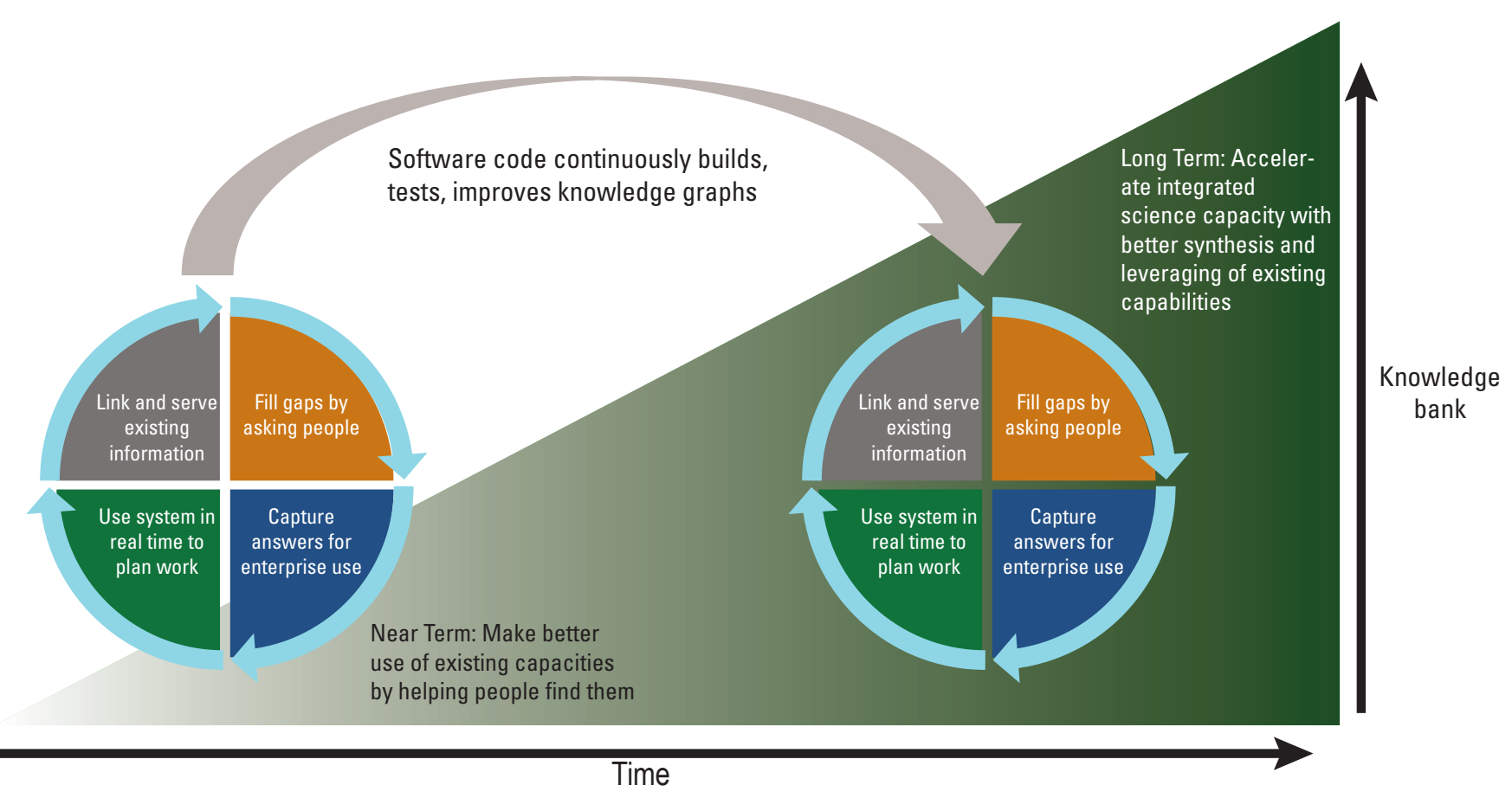

Figure 17. Vision for a continuous capacity assessment capability. 


\section{Capacity Assessment Survey}

The capacity assessment survey yielded important findings and recommendations related to existing expertise and activities needed to support EarthMAP priorities, with three overarching findings.

(1) Capacity is limited in some critical disciplines, skills, and technology applications, but "sufficient" depends on the question and the need relative to availability at a given point in time.

Advances in technology often outpace our ability to incorporate them into common practice, yet they might be key to helping improve efficiency of data collection and data integration/summary. The survey results indicate that adoption of many of the technologies and data processing and integration approaches identified as important is not yet widespread. Similarly, integration of nontraditional data sources does not appear to be common. As the need for more data over a wider geographic footprint expands, so will the need for the USGS to adopt a more consistent and collaborative approach to collecting acceptable data inputs. It will be critical to determine current and future needs for specific data or technologies, methods to accelerate data processing, and information delivery in a form and function that directly supports management actions.

Economics/socioeconomics, operational forecasting, cloud computing and high-performance computing, decision analysis, user experience/design skills, and policy analysis are all areas of expertise that have been identified as important for advancing the goals of the USGS 21 st century science strategy, yet these fields had the lowest reported numbers of "advanced" practitioners. Further development of internal capacity and external partnerships to incorporate these areas of expertise could be explored using CoPs, mentorship, or targeted training programs.

Although the USGS has a strong tradition of developing working relationships with stakeholders and of designing activities so that our science meets their information needs, only 56 out of 732 respondents listed "underserved communities" among their stakeholders and just 30 respondents listed "non-English speaking communities." Recognizing the needs of these groups and effectively providing information to them can require skills and approaches that are unfamiliar to many USGS scientists. The work of staff actively providing information to these groups could be highlighted, and training resources, such as Technical Training in Support of Native American Relations (TESNAR) grants, could be offered to scientific and technical staff on effective engagement to understand and support the science information needs of these communities.

It is likely that greater adoption of the capabilities and technologies mentioned earlier will enhance the USGS ability to provide timely information that supports complex decisions in an increasingly interconnected world. However, the degree to which providing actionable information requires these approaches depends on the nature of the targeted decisions. Further investigation of capacity relative to articulated needs is necessary to determine whether areas of low adoption currently represent gaps in capacity. Development and adoption of a continuously updated capacity assessment capability like described herein would enable rapid evaluation of existing expertise to support decision needs as they arise. Additionally, such a system would allow for tracking capacity over time using a consistent and comparable approach. Related recommendations to improve the effectiveness of such a system include (1) update the USGS Thesaurus to contain a more comprehensive controlled vocabulary of expertise terms, particularly those related to USGS science priorities; (2) encourage greater adoption of Staff Profiles to describe work and expertise and provide a mechanism to easily select expertise terms from the USGS Thesaurus; (3) adopt the technical cyberinfrastructure recommendations detailed in appendix 5 to better enable mining and integration of information about individuals and their projects from USGS enterprise information systems and better enable mining and integration of information about individuals and their projects from USGS enterprise information systems.

(2) Institutional barriers and lack of awareness constrain the ability of USGS staff to adopt new technologies, collaborate across administrative boundaries, and deliver actionable information to our stakeholders in a timely manner. However, these barriers are not universally experienced.

Lack of local expertise and lack of available equipment were the second and third most reported barriers to adopting new data collection and integration technologies and approaches. Similarly, lack of expertise was the second most frequently reported barrier to improving stakeholder engagement and delivery of actionable information. The combined efforts of this survey and iSAID development revealed where critical expertise exists and who is adopting certain novel technologies. The ability to find resources is an important first step toward leveraging those resources. Development of an on-demand capacity assessment capability supported by software that delivers dynamic and continuously updated data from our existing information systems could improve leveraging of existing USGS science and technical capacity and generate opportunities for internal knowledge and technology transfer.

Differing business models across the mission areas and "USGS or USDOI policy" were commonly cited as a barrier to adopting new data collection and integration approaches. Though some survey participants cited specific policies, others responded only in general terms. Targeted inquiries beyond this survey could clarify specific policies obstructing the adoption of new technologies and approaches or the sharing of expertise and equipment across organizational and regional boundaries. These inquiries could inform consideration of whether policies can be revised or whether lack of understanding is creating perceived obstacles. 
Despite reported institutional and policy barriers ("our cooperators have often made the decisions without our input because of our strong Fundamental Science Practices"), some staff have successfully adopted new technologies and approaches to advance EarthMAP priorities and provide actionable information in a timely manner ("we... deliver operational aftershock forecasts"). Highlighting the latter cases and how they are achieved can spread awareness of strategies to navigate perceived obstacles when appropriate.

Finally, network bandwidth, data storage, and software or platform portability were commonly cited obstacles to adopting new data collection and integration approaches as well as to incorporating more stakeholder engagement, decision science, and innovative science communication approaches. In some cases, information technology infrastructure resources may be available, but lack of awareness or organization policies limit access. In other cases, new capacity may be needed.

(3) Examples of people and projects integrating across disciplines and scales and applying advanced approaches to meet complex stakeholder needs exist.

The USGS has the capability to address a wide range of interdisciplinary, multiscale issues, either through internal collaboration or with established partners. Many projects, already underway, appear to meet elements of the EarthMAP vision, and the USGS has a small cohort of staff who understand and have experience in the practical aspects of data and science integration. Expertise in cross-discipline integration is specific to the disciplines and the topics being addressed, and current USGS staff include those who can provide leadership in multiple types of specific integrated science efforts.

The variety and types of models used by survey respondents showcase the diversity and strength of USGS predictive science expertise. Although the scales that USGS scientists tend to work typically reflect the needs of the individual projects and funding sources, existing models have the current potential to be scaled to different geographies or timeframes and others are potentially scalable with additional investment in model application and data acquisition.

The greatest promise for developing integrated science might lie in linking across existing projects and expertise to create a multi-project capacity for addressing large, complex environmental issues. This approach would leverage existing efforts and funding with new opportunities, as available, filling gaps to advance the EarthMAP vision. Existing projects that characterize one or more EarthMAP principles should ideally be highlighted, incentivized, integrated, and built on to advance toward further realization of the EarthMAP vision.

\section{Acknowledgments}

We gratefully acknowledge the support and guidance provided by the Earth Monitoring, Analysis, and Prediction (EarthMAP) Program Management Team, including Gary Rowe, Sky Bristol, John Haines, Karen Jenni, Leslie Jones, Allison Shipp, Terry Sohl, Nancy Sternberg, and Jake Weltzin. We thank Stephen Gillespie for input on survey design. We also thank Katharine Dahm, Karen Jenni, and Jake Weltzin for helpful feedback on this report and all survey participants for generously offering their information and perspectives on U.S. Geological Survey capacities and needs.

\section{References Cited}

Berners-Lee, T., Hendler, J., and Lassila, O., 2001, The semantic web: Scientific American, v. 284, no. 5, p. 34-43, https://doi.org/10.1038/scientificamerican0501-34.

Jenni, K.E., Goldhaber, M.B., Betancourt, J.L., Baron, J.S., Bristol, R.S., Cantrill, M., Exter, P.E., Focazio, M.J., Haines, J.W., Hay, L.E., Hsu, L., Labson, V.F., Lafferty, K.D., Ludwig, K.A., Milly, P.C., Morelli, T.L., Morman, S.A., Nassar, N.T., Newman, T.R., Ostroff, A.C., Read, J.S., Reed, S.C., Shapiro, C.D., Smith, R.A., Sanford, W.E., Sohl, T.L., Stets, E.G., Terando, A.J., Tillitt, D.E., Tischler, M.A., Toccalino, P.L., Wald, D.J., Waldrop, M.P., Wein, A., Weltzin, J.F., and Zimmerman, C.E., 2017, Grand challenges for integrated U.S. Geological Survey science-A workshop report: U.S. Geological Survey Open-File Report 2017-1076, 94 p., https://doi.org/10.3133/ofr20171076.

Nelson, J.C., Brown, D.S., Flickinger, A.K., Gunther, G.L., Keisman, J.L., Murdoch, P.S., Steyer, G.D., Thomas, K.A., and Waite, I.R., 2021, USGS Earthmap Capacity Assessment Dataset: U.S. Geological Survey data release, https://doi.org/10.5066/P9BB5NMZ.

Nuseibeh, B., and Easterbrook, S., 2000, Requirements engineering-A roadmap, in Finkelstein, A.C.W., ed., The future of software engineering: New York, ACM Press, p. $147-160$.

U.S. Geological Survey, 2021, U.S. Geological Survey 21 st-century science strategy 2020-2030: U.S. Geological Survey Circular 1476, 20 p., https://doi.org/10.3133/cir1476.

Wenger, E., 1998, Communities of practice-Learning, meaning, and identity: Cambridge University Press, 336 p., https://doi.org/10.1017/CBO9780511803932. 


\section{Glossary}

Actionable information (also called "actionable intelligence") Data and information that are tailored to stakeholder needs, efficiently assembled, and delivered at timescales relevant to facilitate decision-making.

Artificial intelligence/machine learning (AI/ML) A broad suite of flexible data-driven empirical approaches for harnessing the power of computing resources to evaluate data, such as underlying patterns and relations, without explicit instructions. In Al/ML, an algorithm "learns" from data, performing tasks that typically require human intelligence. Structured data are provided to an algorithm, which learns patterns within the data to make predictions.

Bayesian Of or relating to an approach to probability in which prior results are used to calculate probabilities of certain present or future events.

Biometric wearables Technologies that can provide reliable data about the physical health and condition of humans and animals.

Code notebooks A form of interactive computing in which users write and execute code, visualize the results, and share insights.

Community of Practice (CoP) A group of people who share a concern or a passion for something they do and learn how to do it better as they interact regularly (Wenger, 1998). Communities of practices are valuable environments for knowledge exchange, accelerating adoption of innovative approaches and technologies, and sharing best practices.

Continuous capacity assessment A proposed U.S. Geological Survey capability to continuously assess institutional capacity.

Co-production The process of producing usable or actionable science through collaboration between scientists and those who use science to make policy and management decisions.

Creative works Published and released products of various kinds that characterize the bulk of the accomplishment of individuals and collectively of the U.S. Geological Survey mission. From a capacity assessment standpoint, they provide direct evidence of capabilities as an institution and the intellectual contributions of the people within the institution.

Data and information integration An improved framework for collecting, assessing, analyzing, and integrating science data and information enterprise-wide.

Data call A request from U.S. Geological Survey management or leadership to assemble current status information on a topic. Often can involve a spreadsheet or web form to collect information about the state of research, data collection, technical assistance, or some other activity across the USGS or its mission areas.

Data pipeline A set of tools and activities for moving data from one system with its method of data storage and processing to another system in which it can be stored and managed differently. Moreover, pipelines allow for automatically getting information from many disparate sources and then transforming and consolidating it in one high-performing data storage.

Decision science The collection of techniques, often quantitative, used to inform decision-making at various spatial, temporal, population, and behavioral scales (https://chds.hsph.harvard.edu/approaches/what-is-decision-science/\#: :text=Decision\%20Sc ience $\% 20$ is $\% 20$ the $\% 20$ collection,the $\% 20$ individual\%20and\%20population $\% 20$ levels).

Digital object identifier (DOI) A persistent interoperable identifier for use on digital networks to uniquely identify academic, professional, and government information such as journal articles, research reports, datasets, models, software codes, interactive tools, and official publications attributed to people and institutions. The DOI registry is a collaboration between DataCite and CrossRef registration entities. See https://www.doi.org/ for more information. 
Dynamic content Dynamic content contains information that is regularly updated. Dynamic content can be interactive or non-interactive but is typically provided in the same format over time.

EarthMAP Earth Monitoring, Analysis, and Prediction (EarthMAP); working term for the U.S. Geological Survey long-term vision to deliver well integrated observations and predictions of the future state of natural systems - water, ecosystems, energy, minerals, hazards - at regional and national scales, working primarily with federal, state, and academic partners to develop and operate the capability.

EarthMAP capacity The tools and capabilities to meet critical natural resource Earth-systems related decision needs effectively and at the speed of decisions.

EarthMAP capabilities Experience and knowledge to use and integrate innovative approaches for data collection, analysis, modeling, and targeted information delivery.

EarthMAP tools The data collection innovations, models, information/computing technologies, cyberinfrastructure, decision support, and science communication solutions necessary to enable the EarthMAP approach and goals.

Grand challenges Fundamental problems with broad societal consequences and solutions in Earth system science. A U.S. Geological Survey (USGS) workshop that was held in 2017 defined four overarching grand challenges and considered large and important issues without obvious near-term solutions for which the USGS can develop the capabilities to address through coordinate and strategic research agendas. See workshop report by Jenni and others (2017).

Graph database A database that represents and stores data as structures with nodes or vertices connected by lines or edges to represent relationships.

Interactive content Interactive content allows active engagement by the end user by providing a custom and responsive interchange with data and tools. The information underlying interactive content can be dynamic or static but is always customizable by the end user.

Knowledge graph A collection of interlinked descriptions of entities-objects, events, or concepts. Knowledge graphs put data in context through linking and semantic metadata which provides a framework for data integration, unification, analytics, and sharing.

Master data A collection of common information elements used across multiple systems of a business or organization that help connect those systems together and often make up a critical source of business intelligence, risk management, and even revenue generation.

Mission area Major topic and program area of U.S. Geological Survey science. Mission areas are Core Science Systems, Ecosystems, Energy and Minerals, Natural Hazards, and Water Resources.

Monte Carlo simulation Monte Carlo simulation performs risk analysis by building models of possible results, substituting a range of values - a probability distribution - for any factor that has inherent uncertainty. It then calculates results repeatedly, each time using a different set of random values from the probability functions.

ORCID (Open Researcher and Contributor ID) A persistent digital identifier that distinguishes individual researchers. This digital identifier is used to share information in and across the research ecosystem with other researchers and other systems, including research institutions, publishers, funders, professional associations, service providers, and stakeholders. Additional information can be found at https://orcid.org/ .

Predictive science A diverse, complex, and growing scientific arena that uses a variety of approaches to better understand the complexity of environmental processes and conditions, usually by using models that predict interactions, rates of change, or future conditions, to better help management decisions.

Python An interpreted, object-oriented, high-level programming language with dynamic semantics.

Radiometrics A measure of the natural radiation in the Earth's surface. 
Representative Concentration Pathway A greenhouse gas concentration (not emissions) trajectory adopted by the Intergovernmental Panel on Climate Change.

Stakeholder Individuals or organizations who stand to gain or lose from the success or failure of a system (Nuseibeh and Easterbrook, 2000), or more broadly, everyone with a vested interest in or who is affected by U.S. Geological Survey (USGS) science; can specifically refer to customers, clients, users, and others directly involved in or affected by a project. The U.S. Department of Interior mission includes serving stakeholders by advancing knowledge through scientific leadership and informing decisions through the application of science. The USGS serves a wide range of stakeholders with varying interests and responsibilities.

Static content Web content that can be delivered to an end user without having to be generated, modified, or processed. Static content rarely changes and doesn't depend on user input or preferences.

Structural equation model (SEM) An approach to statistical modeling that focuses on the study of complex cause-effect hypotheses about the mechanisms operating in systems. It is a collection of statistical techniques that allow a set of relationships between one or more independent variables (IVs), either continuous or discrete, and one or more dependent variables (DVs), either continuous or discrete, to be examined.

TESNAR U.S. Geological Survey (USGS) Technical Training in Support of Native American Relations is a grant program providing funds to support USGS employees to design and conduct technical training for staff of tribal governments or organizations.

Traditional ecological knowledge A cumulative body of knowledge, practice, and belief evolving by adaptive processes and handed down through generations by cultural transmission about the relationship of living beings (including humans), with one another, and with their environment. As a knowledge-practice-belief complex, traditional ecological knowledge includes the religious traditions of a society.

Transfer value The value of science knowledge collected at one location that is useful to understanding environmental conditions at another location.

Uncertainty analysis An approach in modeling of environmental data and processes that aims to characterize or quantify the uncertainty of variables used in decision making. Uncertainty analysis estimates the variability of the output that results from the variability of the input. The analysis might rely on uncertainty propagation techniques performed by estimating statistical quantities of interest.

Use cases Short descriptions of science applications that clearly address high priority decision-making needs relevant to our stakeholders and require the integrated science focus of EarthMAP.

USGS Staff Profiles A U.S. Geological Survey (USGS) hosted platform for employees to describe their work and expertise (https://www.usgs.gov/connect/staff-profiles).

USGS Publications Warehouse Catalog of U.S. Geological Survey authored reports and products that provides access to over 160,000 publications over the century-plus history of the Bureau (https://pubs.er.usgs.gov/).

USGS Science Data Catalog (SDC) Catalog of U.S. Geological Survey (USGS) open data and metadata available for retrieval, visualization, download, and linking back to original data provider (https://data.usgs.gov/datacatalog/). The SDC is a member node to the National Science Foundation sponsored DataOne Project (https://www.dataone.org/).

USGS ScienceBase A collaborative scientific data and information management platform used directly by science teams (https://www.sciencebase.gov/). ScienceBase provides access to aggregated information derived from many data and information domains, including feeds from existing data systems, metadata catalogs, and scientists contributing new and original content. 
USGS ScienceBase Directory A component of U.S. Geological Survey (USGS) ScienceBase that catalogs people and organizations to provide comprehensive information about organization structure and to allow the linking of cataloged information records to their origin (person who produced the work) and affiliation (organization that sponsored the work). See www.sciencebase.gov/directory.

USGS Thesaurus A controlled vocabulary providing category terms for scientific information products generated by the U.S. Geological Survey. See https://apps.usgs.gov/thesaurus/. 


\section{Appendix 1. Survey Questions and Summary of Responses}

The survey consisted of 44 possible questions distributed in 5 sections. Three of the sections were optional based on initial answers to section topics. Survey questions are listed here, followed by a parenthetical description of the type of answer (in other words, open text, controlled list, controlled list + other [narrative], narrative text). For a list of all controlled lists associated with each question, see $\left(^{*}\right)$.

\section{Respondent Information}

1. Physical office location (city, state) (open text)

2. What is your current level of familiarity with EarthMAP? (controlled list). Colors in fig $1.1 B$ correspond with categories shown in fig. 1.1A.

3. Which of the following categories characterizes the focus of your work? Select all that apply: (controlled list+other).

4. Which of the following Earth system disciplines best characterizes your skills and experience? Check all that apply: (controlled list + other).
5. The 2017 "Grand Challenges" report identified several complex societal challenges, without obvious near-term solutions, that the USGS's unique combination of expertise positions us to address. Are you, or have you been, involved in projects that provide(d) such "actionable" information to stakeholders on the following complex issues? (controlled list+other).

6. Select your level of skill and experience in the following areas: (table of skills with four categories of experience).

7. Do you have skills and experience that you feel were not covered in the previous question that you would like to describe here? How might they contribute to delivery of actionable information to stakeholders at the scale and speed of their decisions? (narrative text box).

8. Have you conducted multidisciplinary efforts to build capacities with scientists from multiple mission areas? If yes, which mission areas and programs? If so, you can provide Uniform Resource Locators (URLs) linking to those efforts. (controlled list + other).

9. Please provide any further details (project links) that you'd like to offer related to the previous question (narrative text box).

\section{What is your current level of familiarty with EarthMAP?}
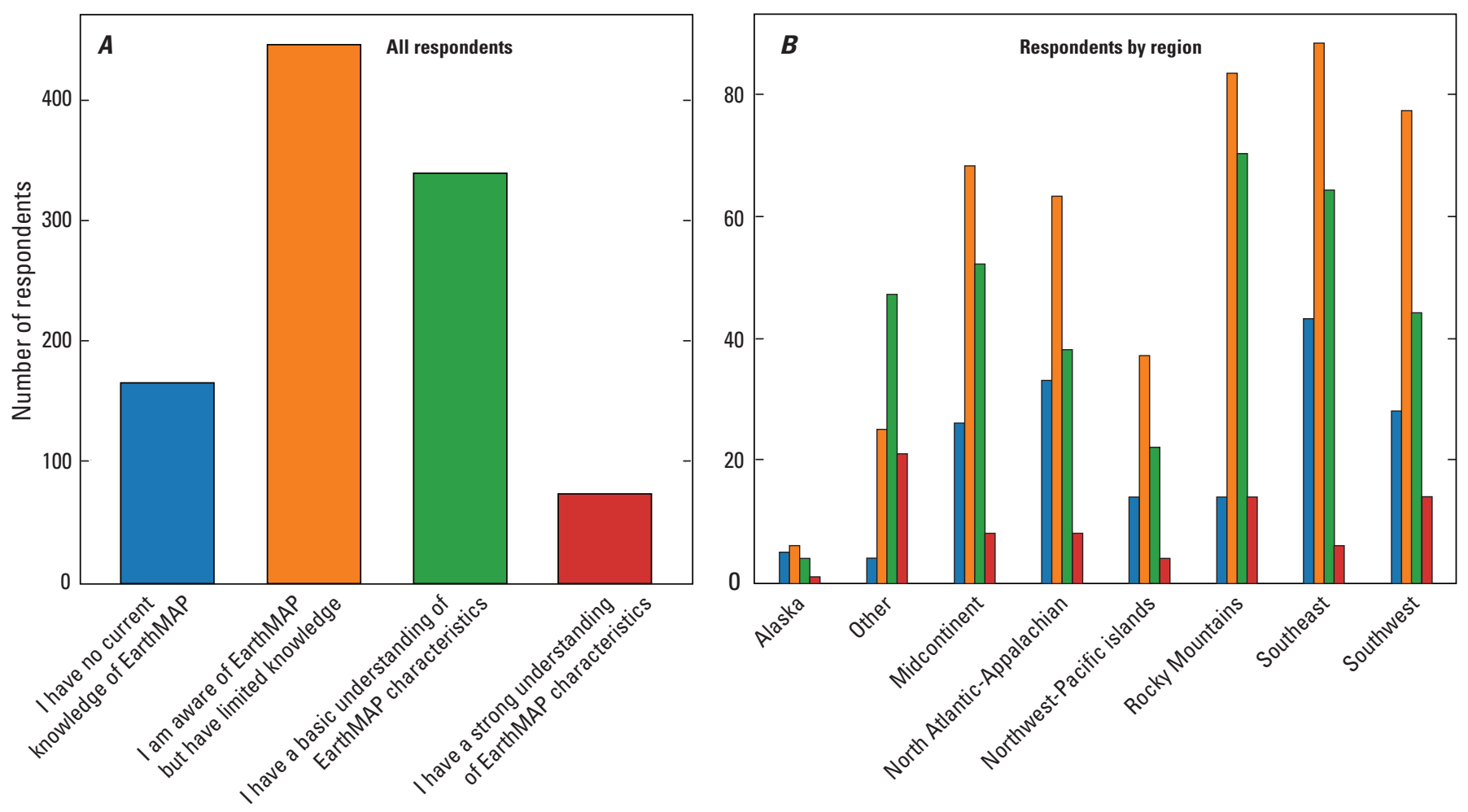

Figure 1.1. Summary of responses to survey question 2 for $A$, All respondents; and $B$, Respondents by region 
03. Which of the following categories characterizes the focus of your work?
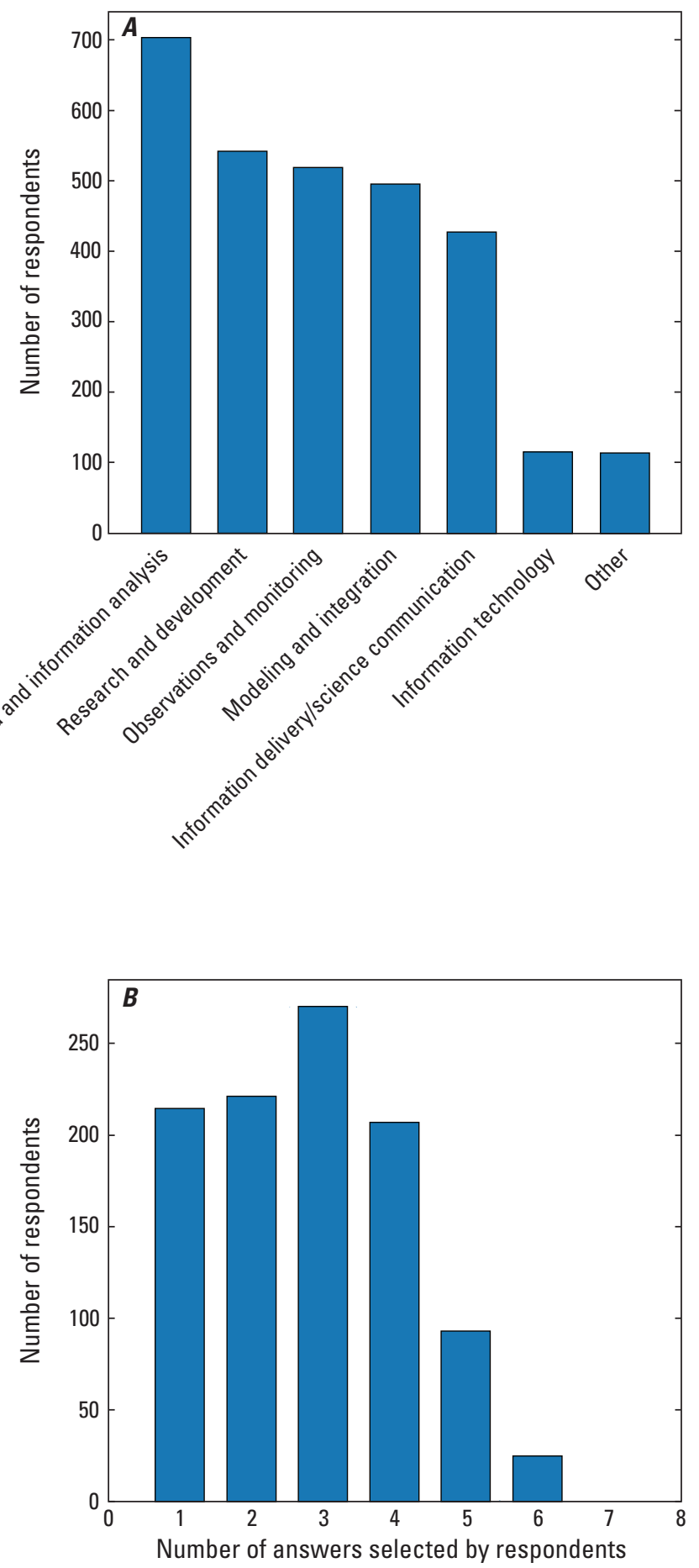

Figure 1.2. Summary of responses to survey question 3 by $A$, category; and $B$, number of answers selected by respondent.

\section{Which of the following Earth system disciplines best characterizes your skills and experience?}

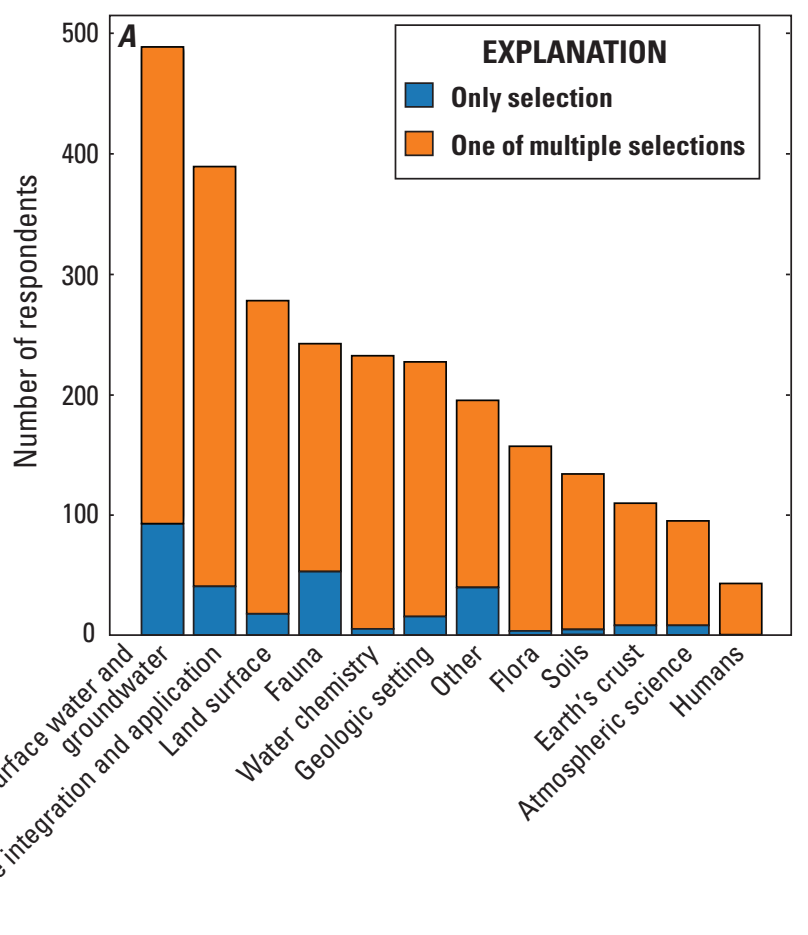

Earth system discipline

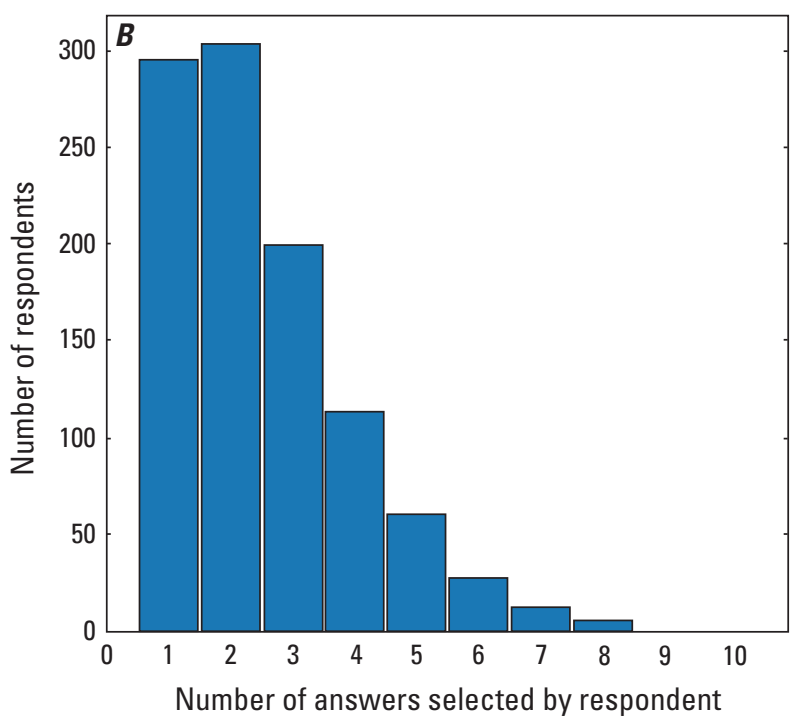

Figure 1.3. Summary of responses to survey question 4 by $A$, Earth system discipline; and $B$, number of answers selected by respondent. 
05. Are you, or have you been involved in projects that provide(d) such "actionable" information to stakeholders on the following complex issues?
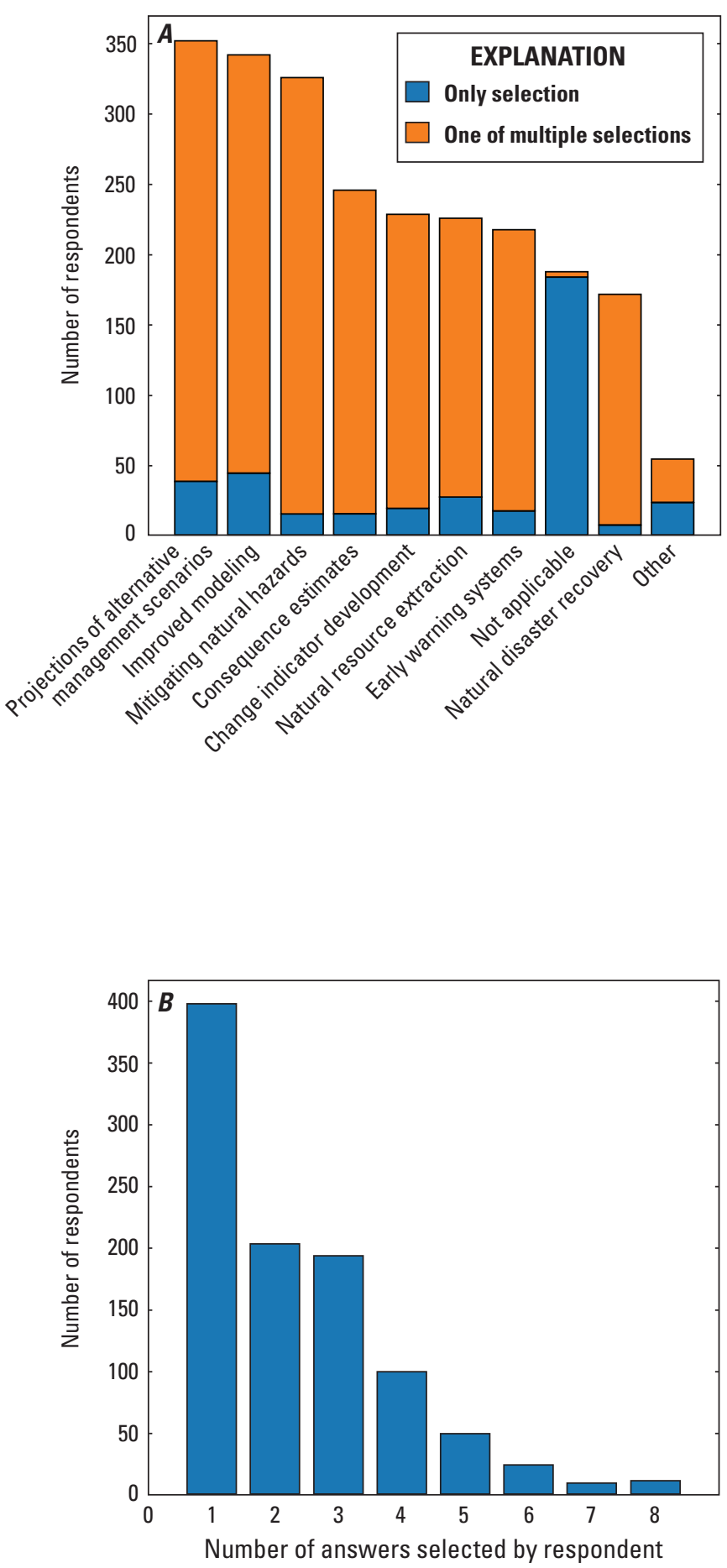

Figure 1.4. Summary of responses to survey question 5 by $A$, complex issues; and $B$, number of answers selected by respondent. 


\section{Q6. Select your level of skill and experience in the following areas:}

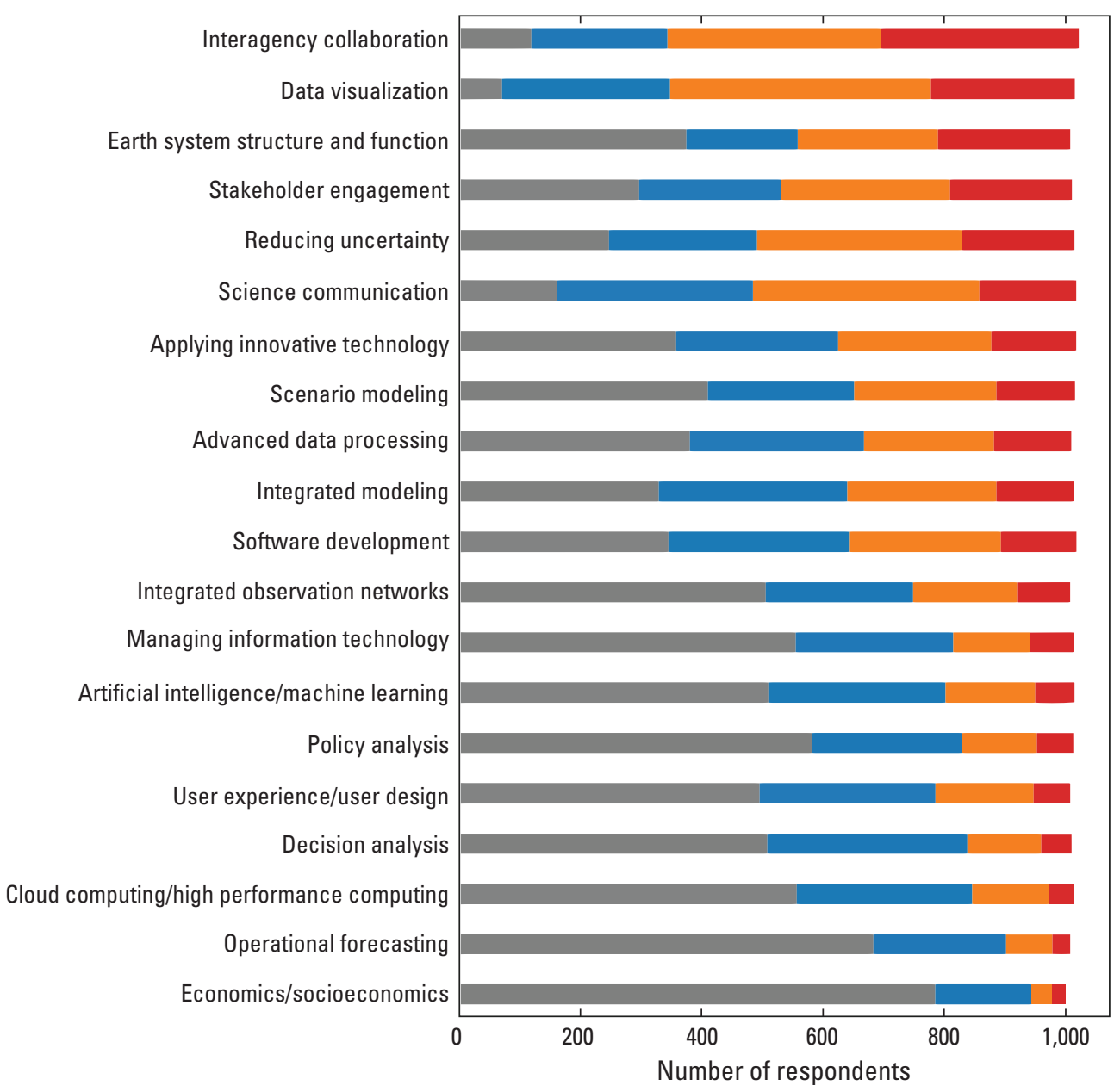

\begin{tabular}{|l|}
\hline EXPLANATION \\
No experience \\
Novice \\
Intermediate \\
Advanced
\end{tabular}

Figure 1.5. Summary of responses to survey question 6. 
08. Have you conducted multidisciplinary efforts to build capacities with scientists from multiple mission areas? Which areas?
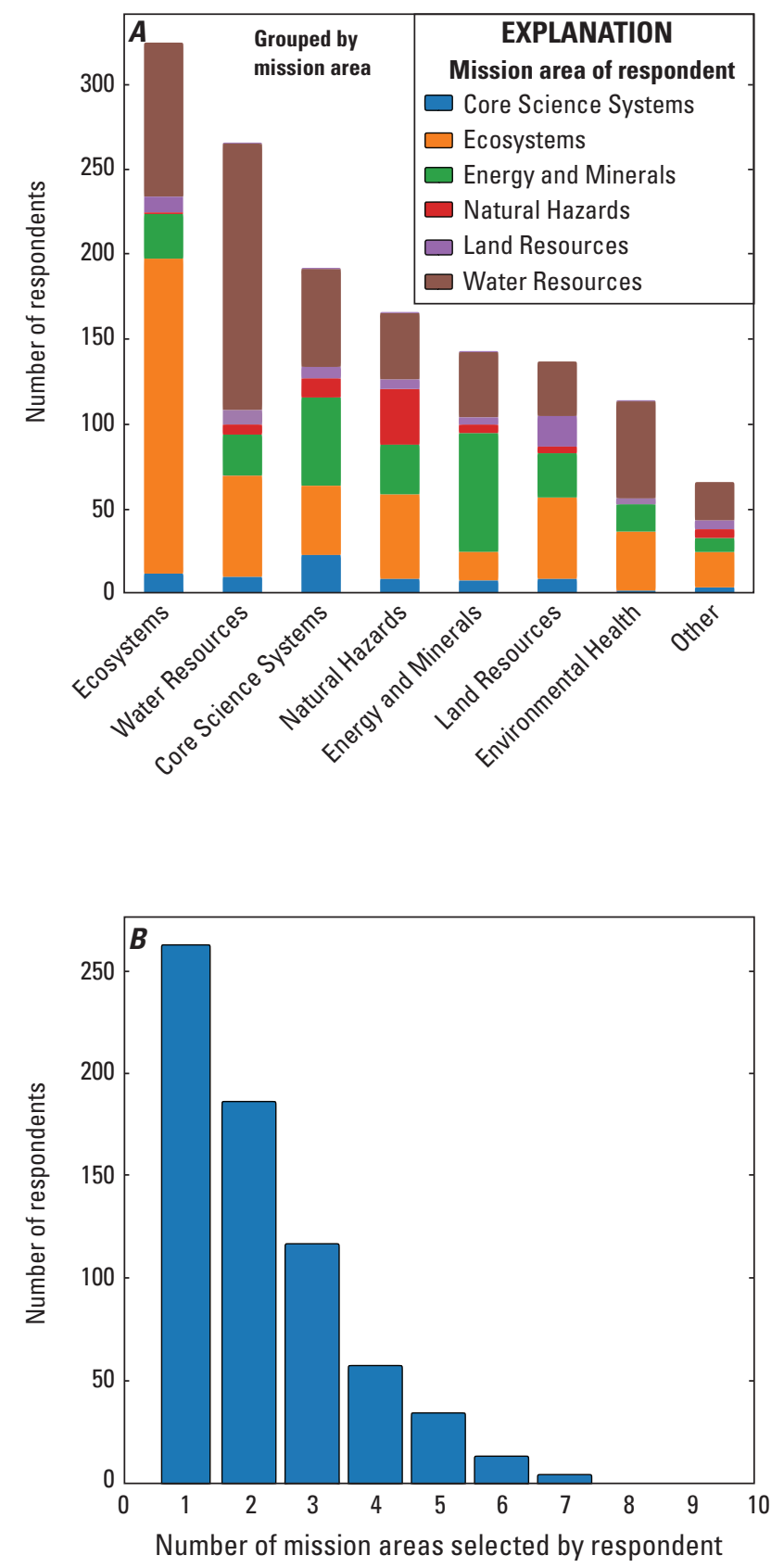

Figure 1.6. Summary of responses to survey question 8 by $A$, mission areas of respondents; and $B$, number of mission areas selected by respondent.

\section{Data and Information Integration}

10. Does your work include data collection, processing, or integration? Yes/No.

If Yes, continue here; if No, go to question 17.

11. Do you utilize or develop any of the following data collection and management technologies in your work? If so, please select your level of experience. (table of technologies with four categories of experience).

12. Does your work incorporate data collection and processing technologies or approaches that enable actionable information at the speed of decisions that were not covered in the previous question? If yes, please let us know what they are and how you see them contributing to this EarthMAP goal. (narrative text box).

13. What barriers limit your ability to utilize new/available data collection and processing technologies more in your work? (controlled list + other).

14. What nontraditional data sources (sources other than those most referenced) do you use in your work? Select all that apply or provide your own examples: (controlled list + other).

15. Are you engaged in or have you been engaged in data collection and integration work that has (select all that apply): (controlled list + other).

16. Please provide any further details that you'd like to offer about your experience, understanding of, or use of data collection and management technologies (Narrative).

\section{Does your work include data collection, processing, or integration?}

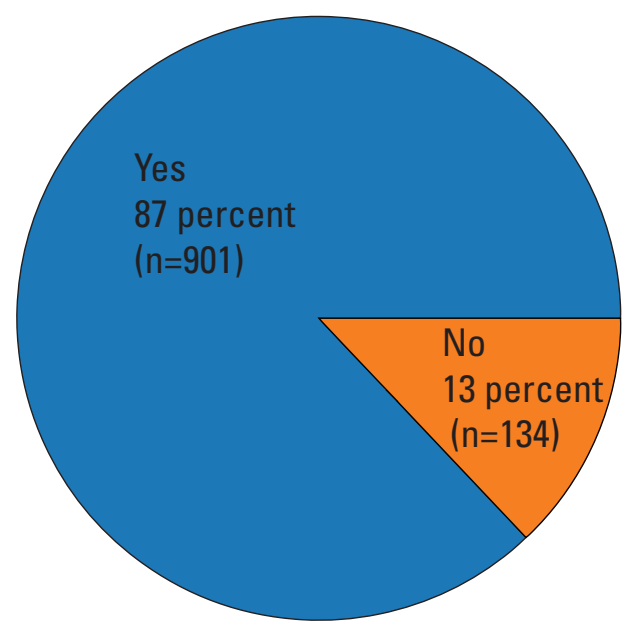

Figure 1.7. Summary of responses to survey question 10. 
011. Do you utilize or develop any of the following data collection and management technologies in your work? If so, please select your level of experience.
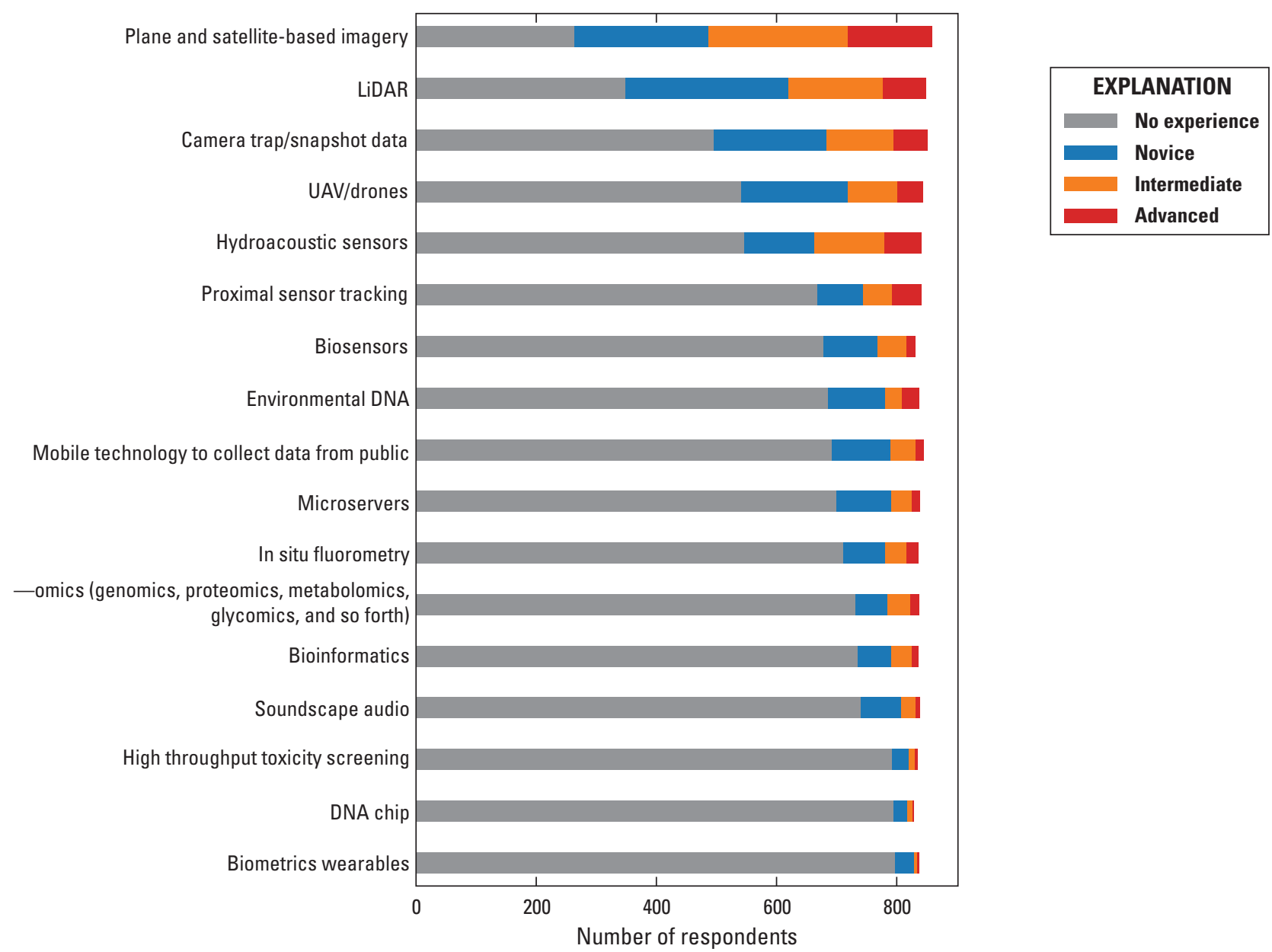

Figure 1.8. Summary of responses to survey question 11. 
013. What barriers limit your ability to utilize new/available data collection and processing technologies more in your work?

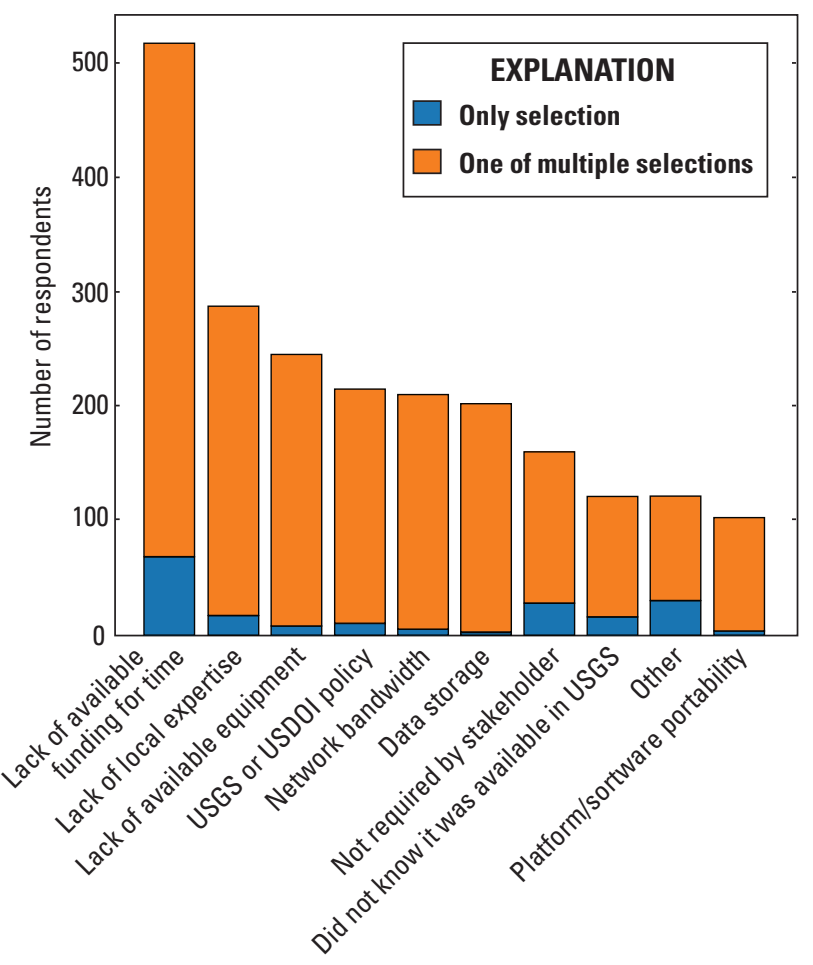

Figure 1.9. Summary of responses to survey question 13. Abbreviations: USGS, U.S. Geological Survey; USDOI, U.S. Department of the Interior.

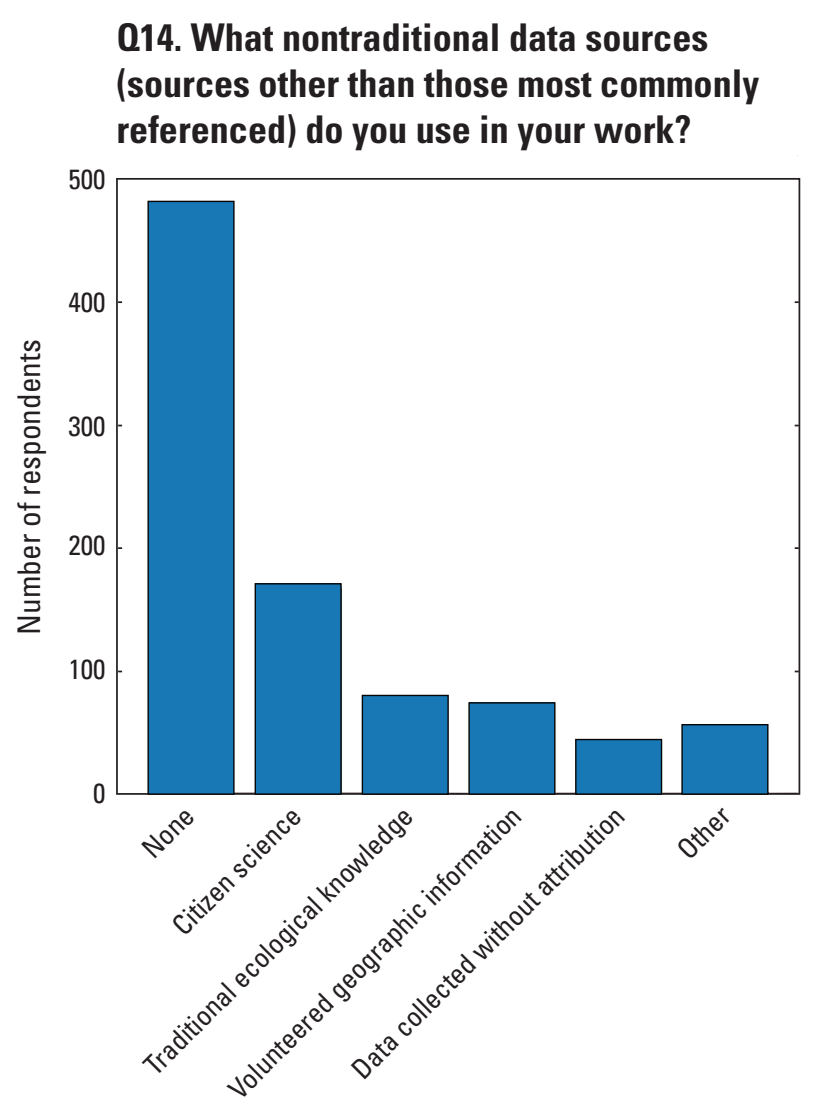

Figure 1.10. Summary of responses to survey question 14. 


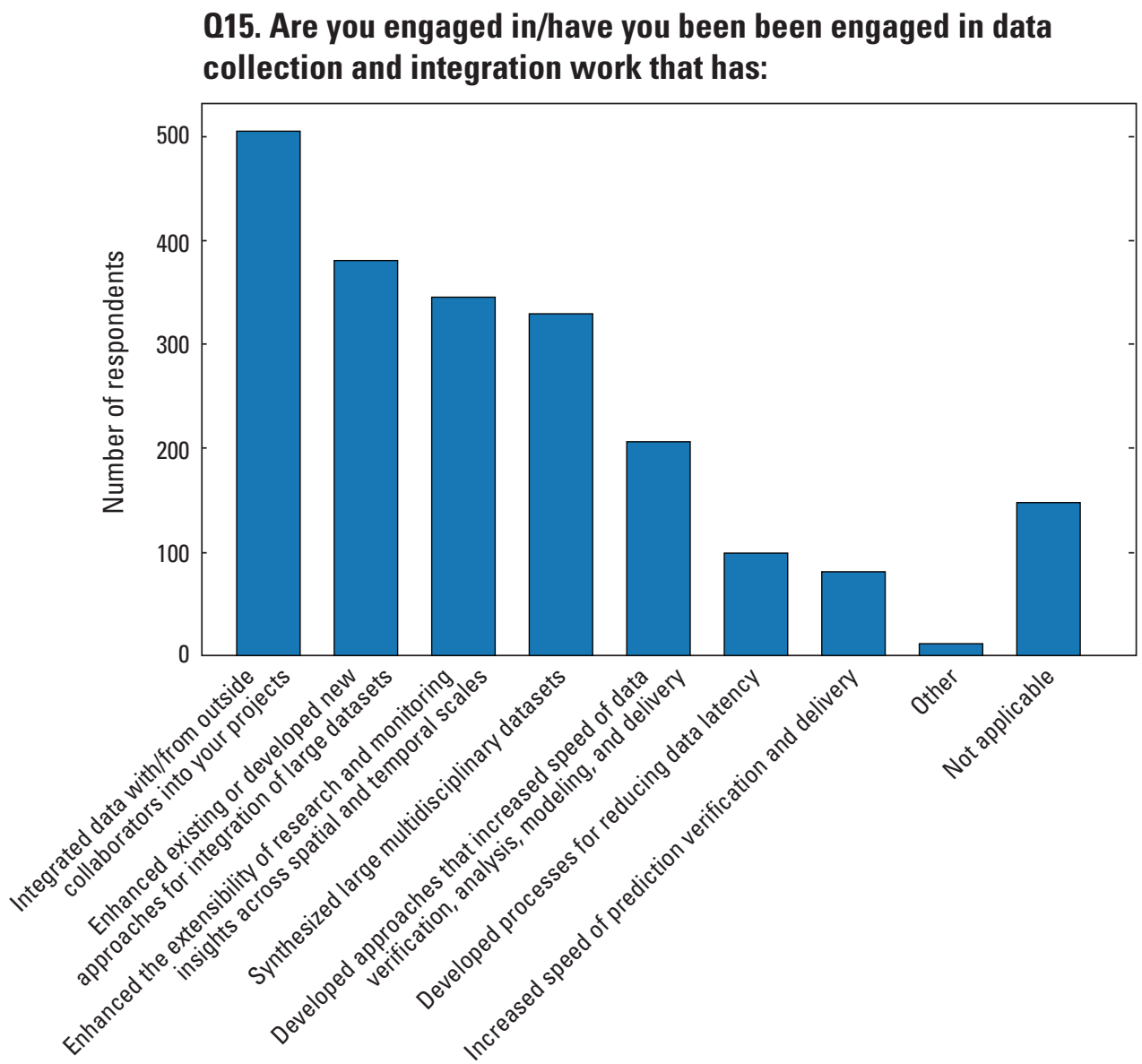

Figure 1.11. Summary of responses to survey question 15. 


\section{Integrated Predictive Science}

17. Do you develop or utilize models that implement advanced approaches for addressing "complex, systems-level problems" (for example, environmental conditions of concern that are the product of multiple processes [for example, hydrologic, biologic, geologic, anthropogenic] at multiple scales, linked effects of multi-resource extraction, and so forth)? Models may be broadly defined, including but not limited to conceptual, theoretical, statistical, deterministic, or qualitative scenario modeling, to name a few. Yes/No.

If Yes, continue here; if No, go to question 30.

18. Please indicate if you have employed any of the following predictive modeling approaches: (controlled list + other).

19. Please list any predictive models that you have used that do not fit into the categories listed (narrative text).

20. Does your predictive science provide uncertainty estimates applicable to decision-making? (Yes, No).

21. If so, how? If not, why not (narrative text)?

22. At what spatial scale(s) have you worked? (check all that apply) (controlled list + other).

23. To what extent is prediction currently being used in your temporal analysis? Choose all that apply: (controlled list + other).

017. Do you develop or utilize models that implement advanced approaches for addressing "complex, systems-level problems?"

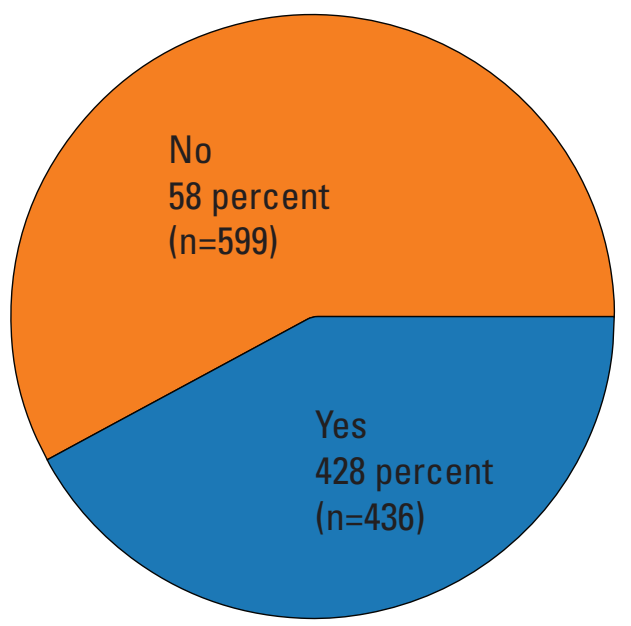

Figure 1.12. Summary of responses to survey question 17.
24. Do you have models that could reliably produce and deliver operational ecological forecasts useful to management decisions? If so, please describe the operational forecast products or applications. (narrative text).

25. Can your predictive models be scaled to other locations and timescales? (choose one) (controlled list + other).

26. Do you incorporate social science or economics into your analysis and modeling activities? (controlled list).

27. If you answered No, why not? (controlled list).

28. If resources were available, would the addition of social and economic data, analysis, and modeling enhance your ability to do the following (controlled list + other).

29. Does your work involve integrated predictive science efforts that you feel were not covered in the previous section that you would like to tell us about? If yes, please describe how you see them contributing to delivery of actionable information to stakeholders at the speed of decisions (narrative text).

\section{Please indicate if you have employed any of the following predictive modeling approaches}

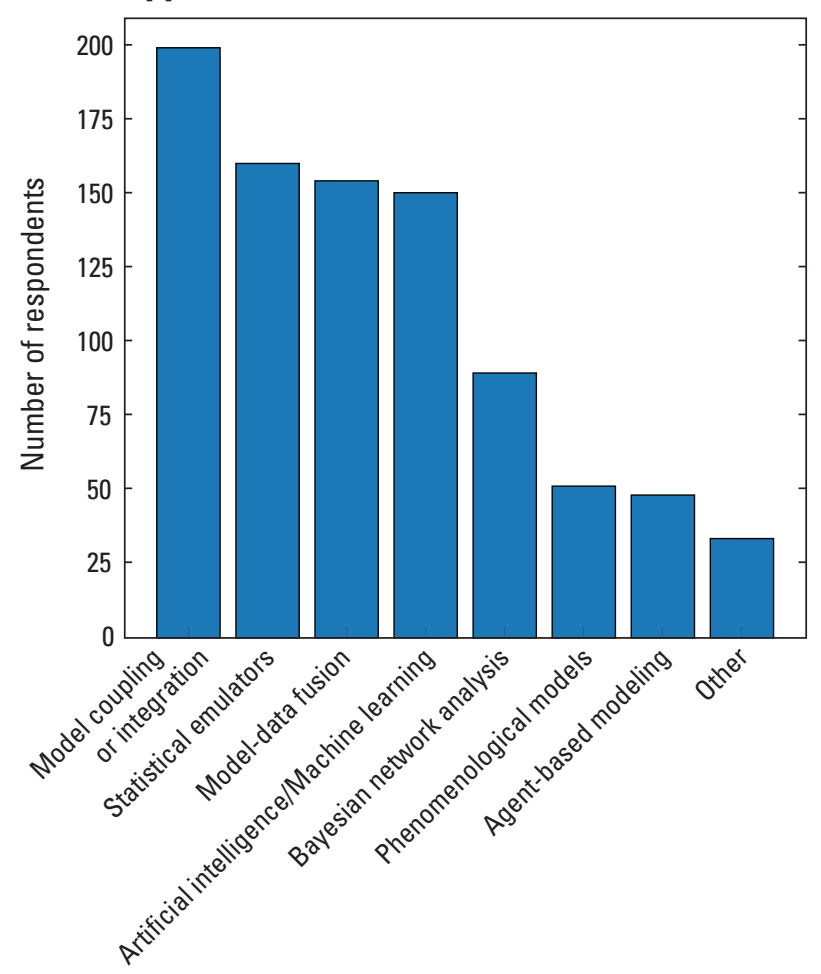

Figure 1.13. Summary of responses to survey question 18. 
020. Does your predictive science provide uncertainty estimates applicable to decision-making?

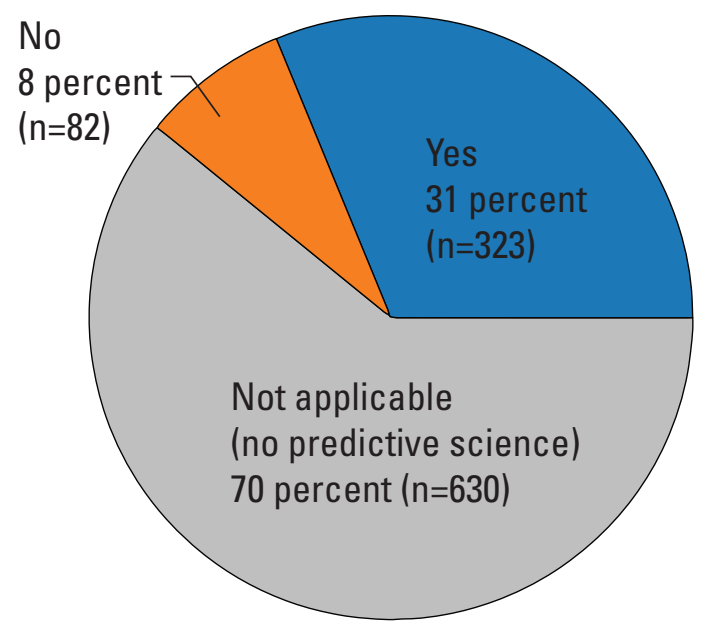

Figure 1.14. Summary of responses to survey question 20.

022. At what spatial scale(s) have you worked?

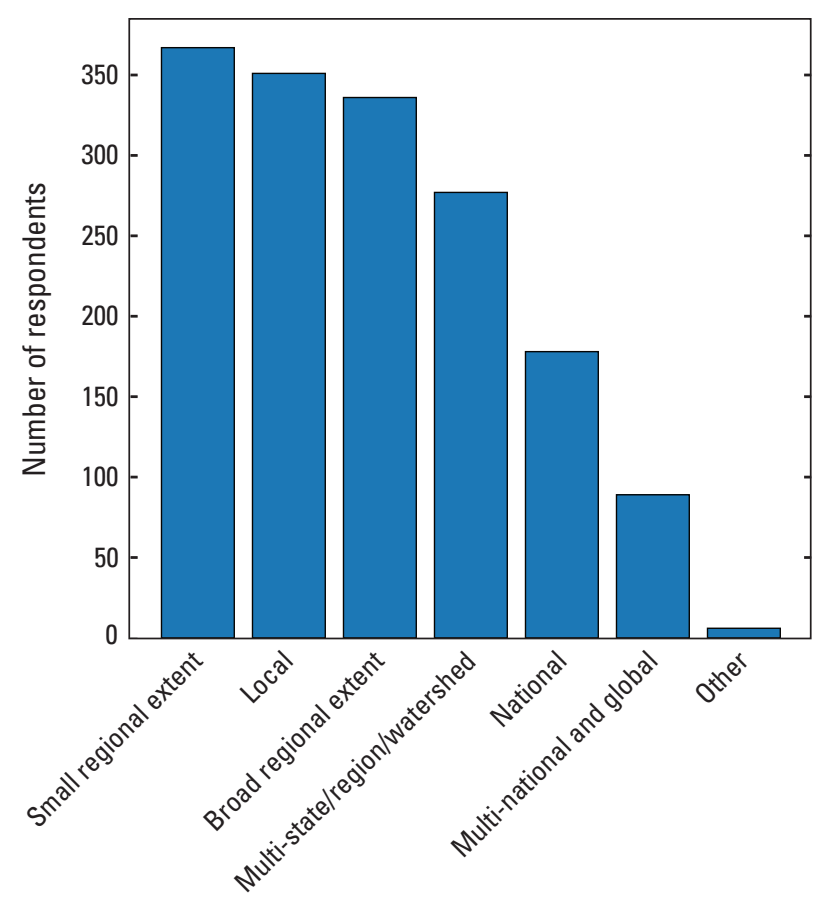

Figure 1.15. Summary of responses to survey question 22 .
023. To what extent is prediction currently being used in your temporal analysis?

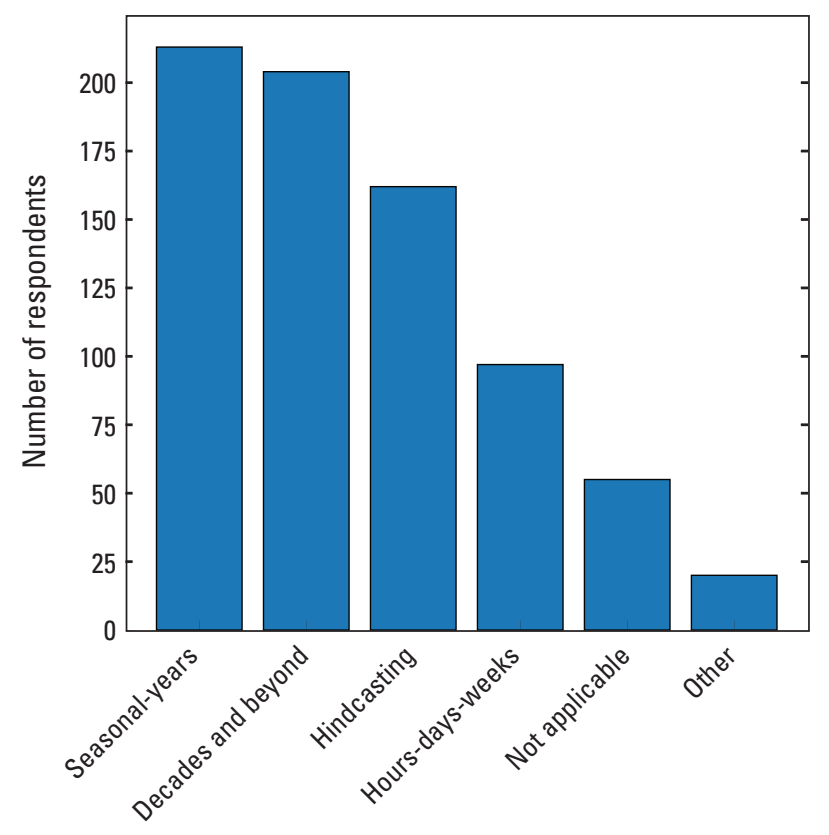

Figure 1.16. Summary of responses to survey question 23. 
025. Can your predictive models be scaled to other locations and timescales?

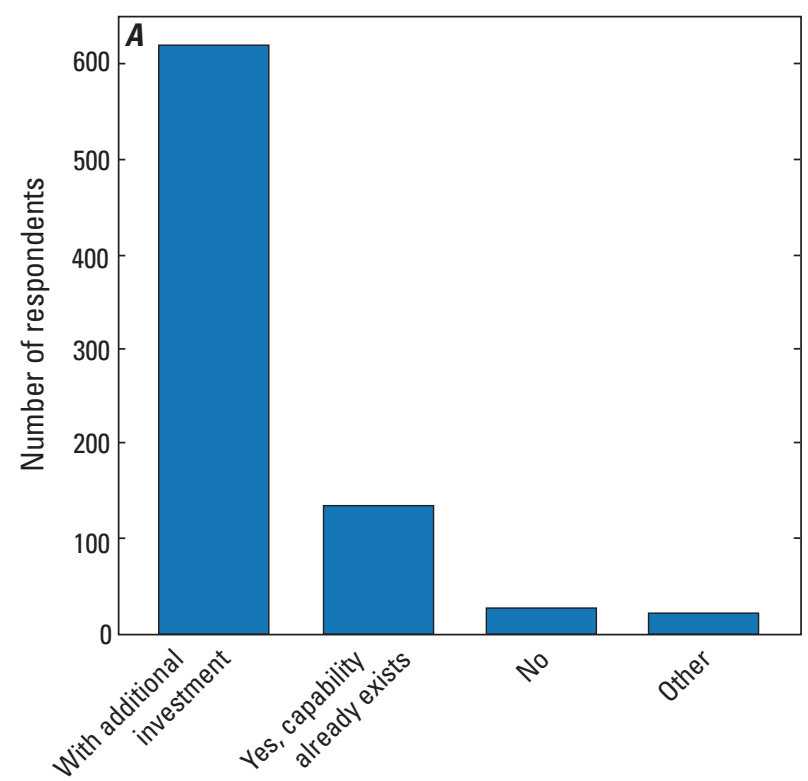

Respondent responses

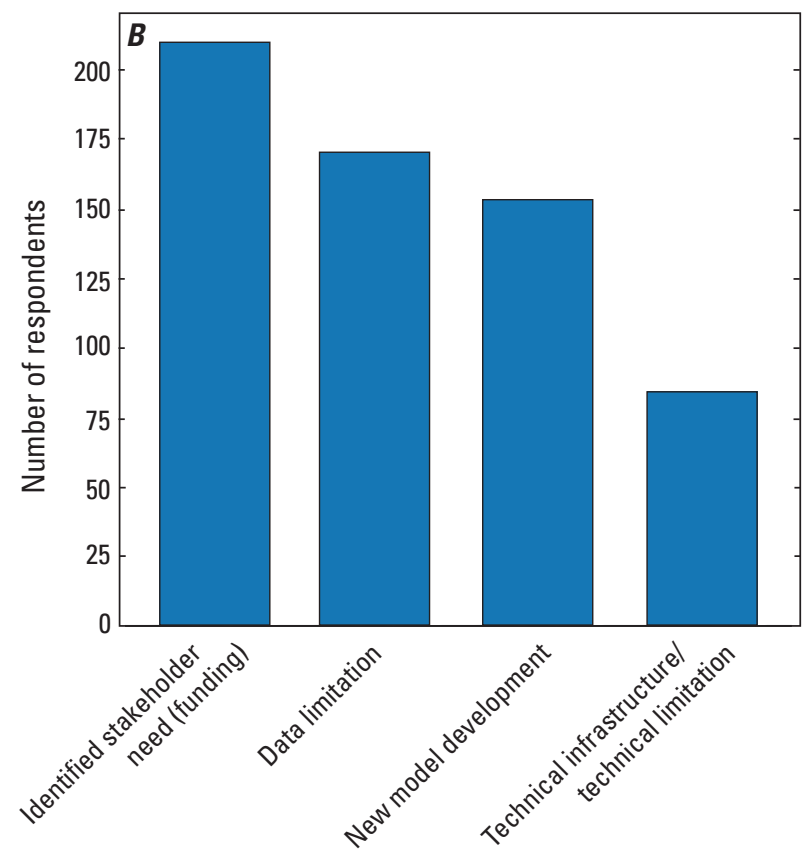

Breakdown of additional investment answers

Figure 1.17. Summary of responses to survey question 25, summarizing $A$, respondent responses; and $B$, a breakdown of additional investment answers.
026. Do you incorporate social science or economics into your analysis and modeling activities?

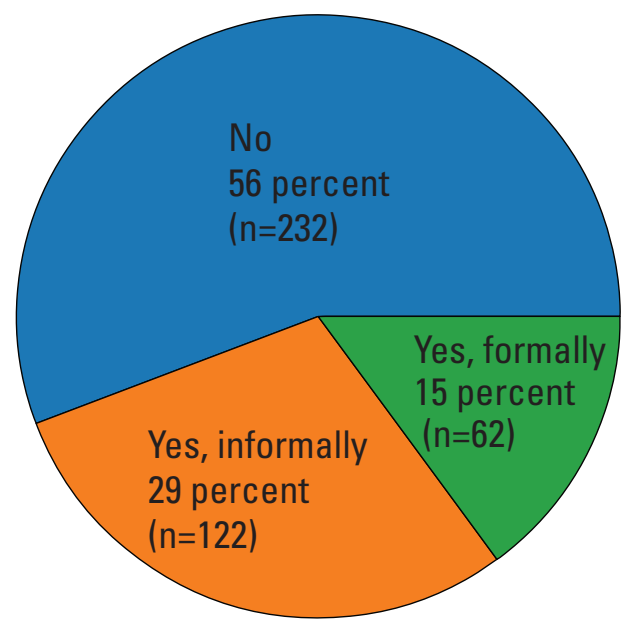

Figure 1.18. Summary of responses to survey question 26 .

028. If resources were available, would the addition of social and economic data, analysis, and modeling enhance your ability to do the following?

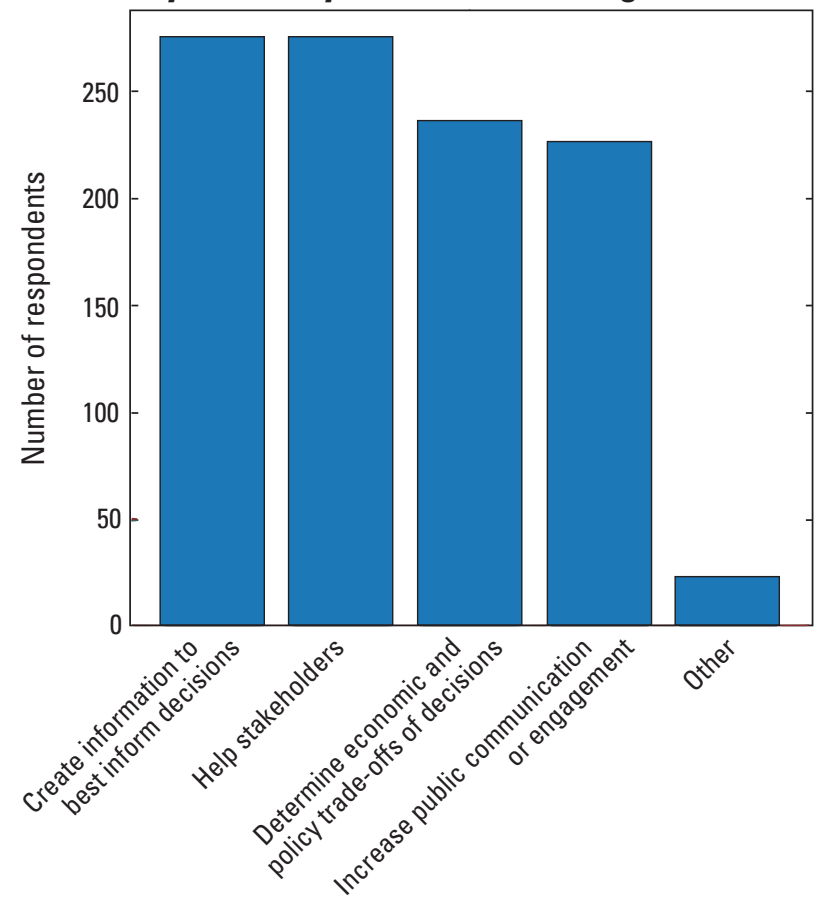

Figure 1.19. Summary of responses to survey question 28 . 


\section{Actionable Information}

30. In your work, do you provide actionable information to decision makers (for example, stakeholders, managers, or the general public), either through direct engagement or through development of science communication tools or materials? (Yes/No).

If Yes, continue here; if No, go to question 43.

31. How would you characterize your skills and experience in engaging with stakeholders to meet project goals (Choose one)? (controlled list + other).

32. Who are your stakeholders (group or agency that will rely on your work for question answering or management decisions)? Select all that apply: (controlled list + other).

33. What specific decision(s) does your science inform? (narrative text).

34. On what timeframe are your stakeholders making their decisions? Select all that apply: (controlled list + other).

35. How have your stakeholder(s) typically been involved in the development of your science efforts? Select all that apply: (controlled list + other).

36. How would you characterize your skills and experience with decision science (techniques used to inform decision-making at various spatial, temporal, population, and behavioral scales), decision analysis, or structured decision making (hereafter "decision science")?

\section{In your work, do you provide actionable information to decision makers?}

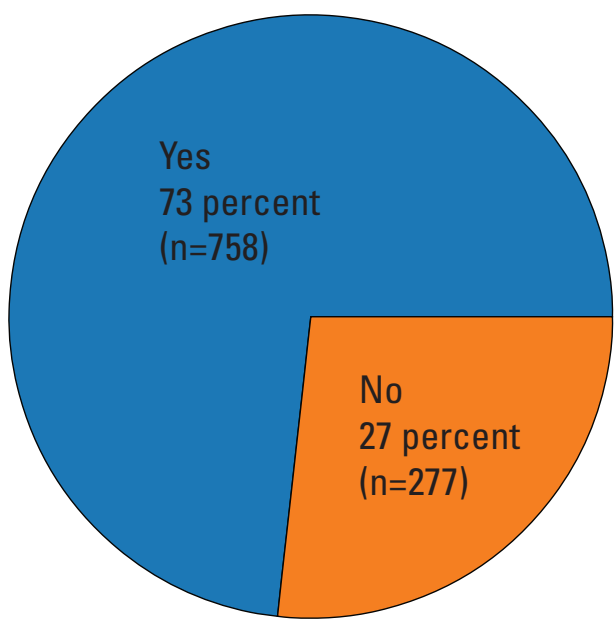

Figure 1.20. Summary of responses to survey question 30.
Examples of decision tools include multi-criteria decision analysis, decision matrix, decision trees, influence diagrams, Pareto analysis, SWOT analysis, probabilistic forecasting, decision modeling, risk analysis. Choose One: (controlled list).

37. In what ways have you incorporated decision science into your work? (controlled list + other).

38. What science communication approaches are you using to improve information delivery to non-scientific audiences? (controlled list + other).

39. Does your projector activity deliver data applications and visualizations on the web? (Yes, No).

40. If yes, what type of data delivery or visualizations does your project deliver to stakeholders, partners, or decision makers? Feel free to include URLs: (narrative text).

41. What barriers limit your ability to incorporate more stakeholder engagement, decision science, and innovative science communication approaches into your work, such as expertise, funding, platform portability, and so forth? (controlled list + other).

42. Does your work provide actionable information to decision makers in ways that were not represented by any of our questions thus far? If yes, please describe them here (narrative text).

\section{How would you characterize your skills and experience engaging with stakeholders to meet project goals?}

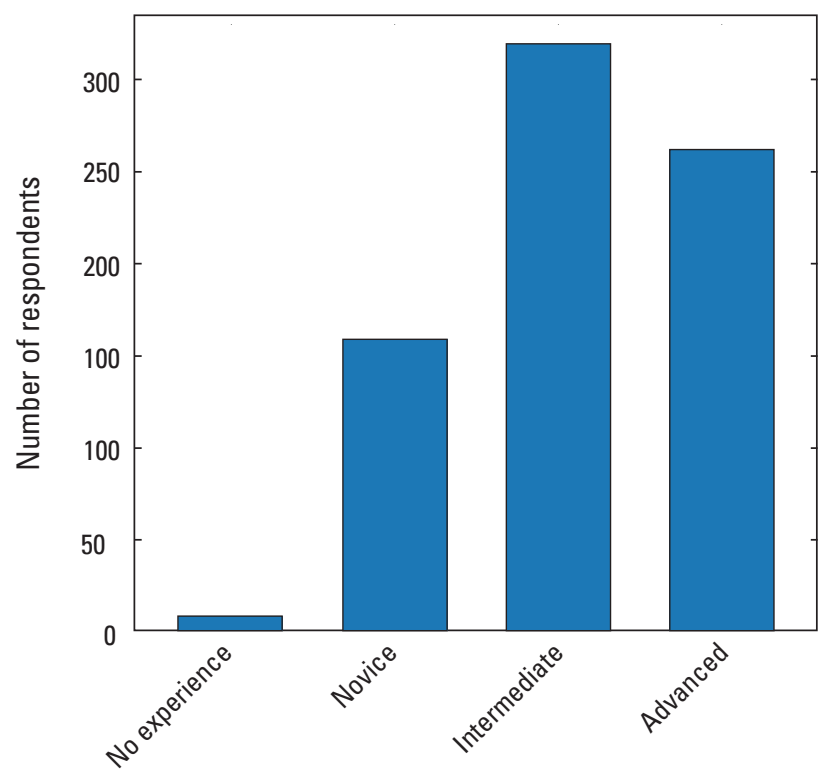

Figure 1.21. Summary of responses to survey question 31. 
032. Who are your stakeholders?
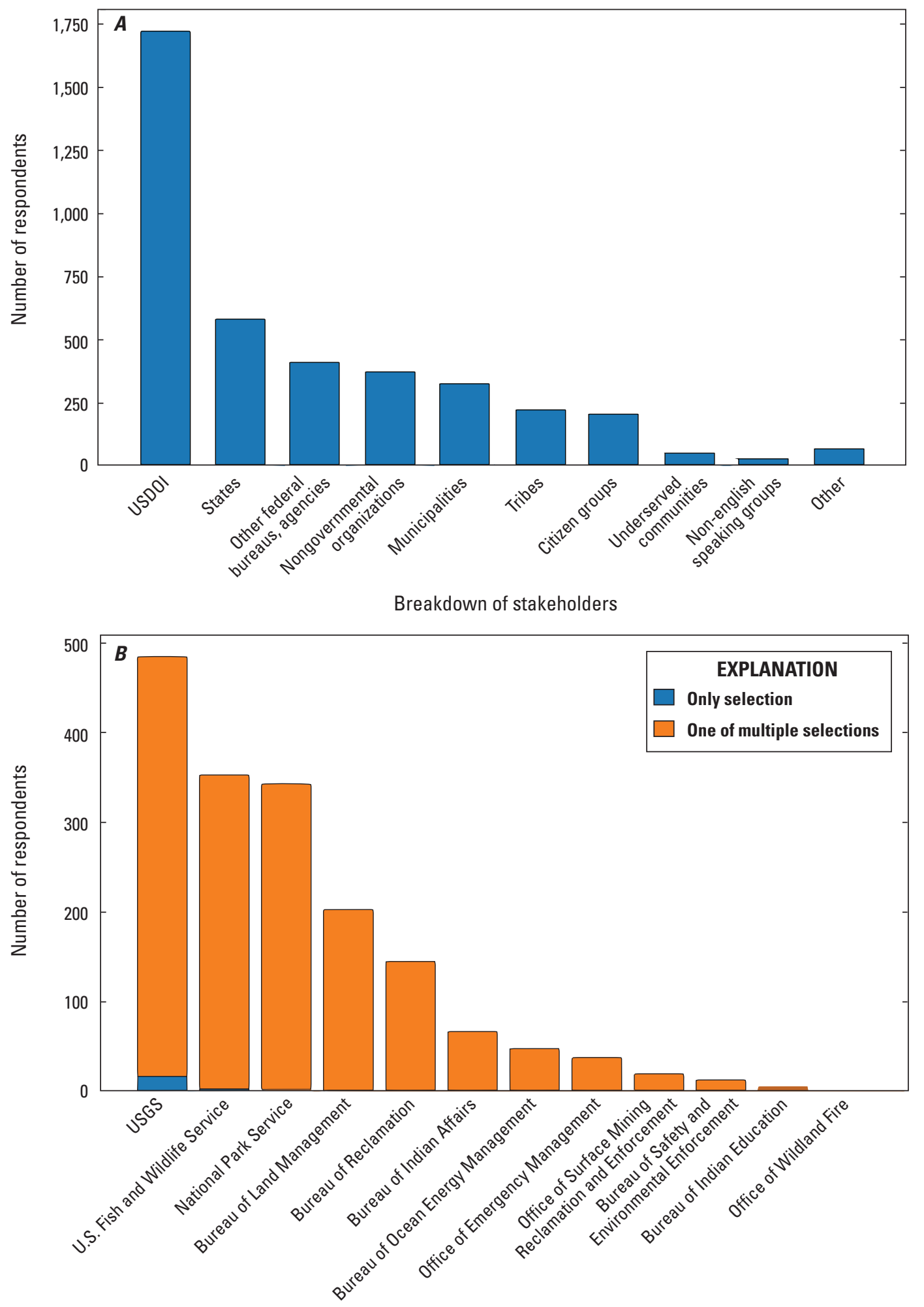

Breakdown of Department of the Interior stakeholders

Figure 1.22. Summary of responses to survey question 32 regarding $A$, stakeholders; and $B$, Department of Interior (USDOI) stakeholders. Abbreviation: USGS, U.S. Geological Survey. 
034. On what timeframe are your stakeholders making their decisions?

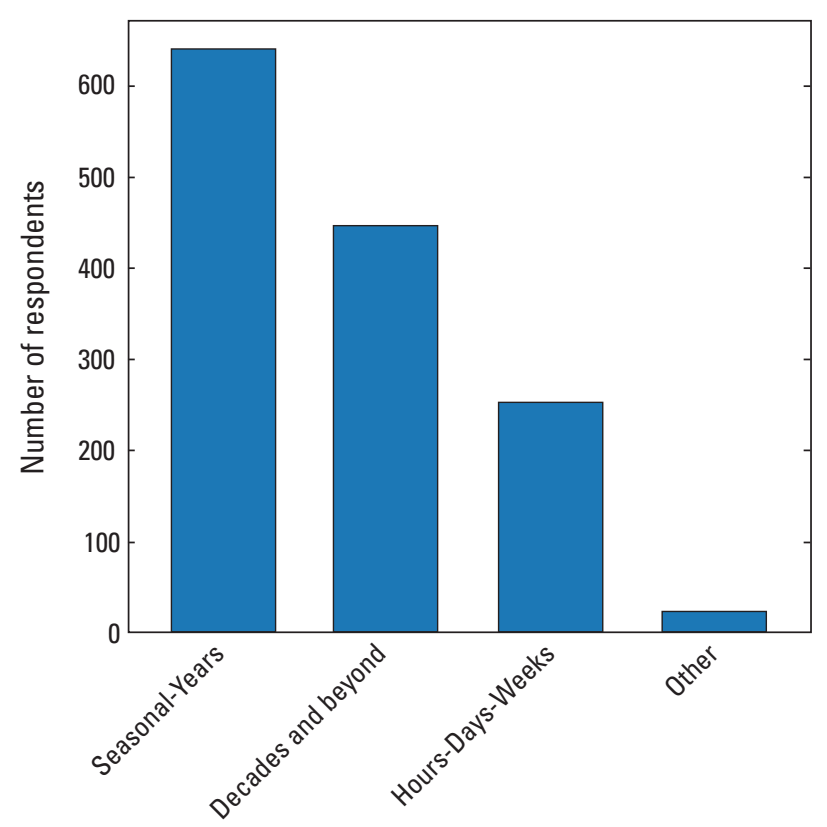

Figure 1.23. Summary of responses to survey question 34 .
035. How have your stakeholder(s) typically been involved in the develoment of your science efforts?
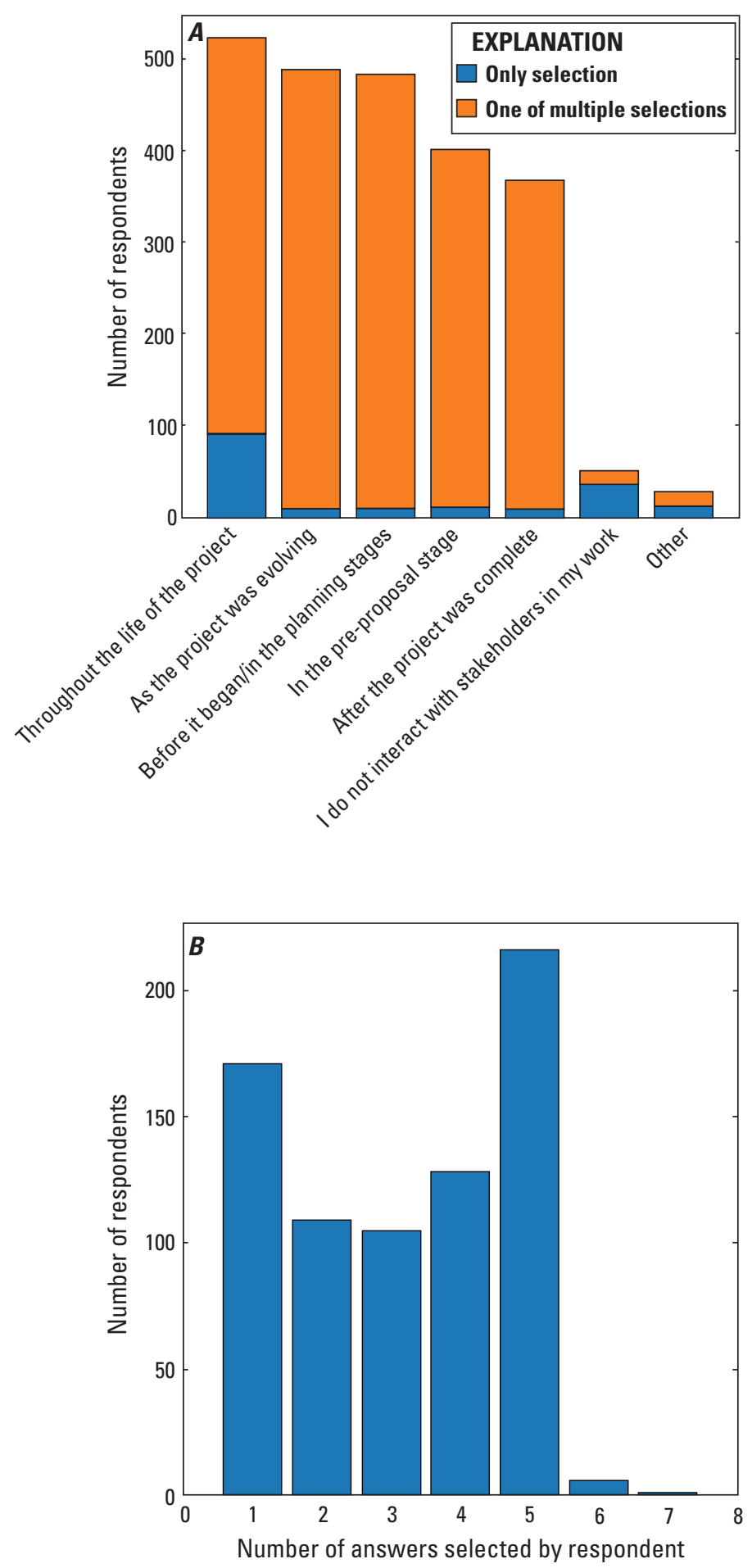

Figure 1.24. Summary of responses to survey question 35 $A$, regarding how stakeholders have been involved; and $B$, by number of answers selected by respondents. 
036. How would you characterize your skills and experience with decision science?

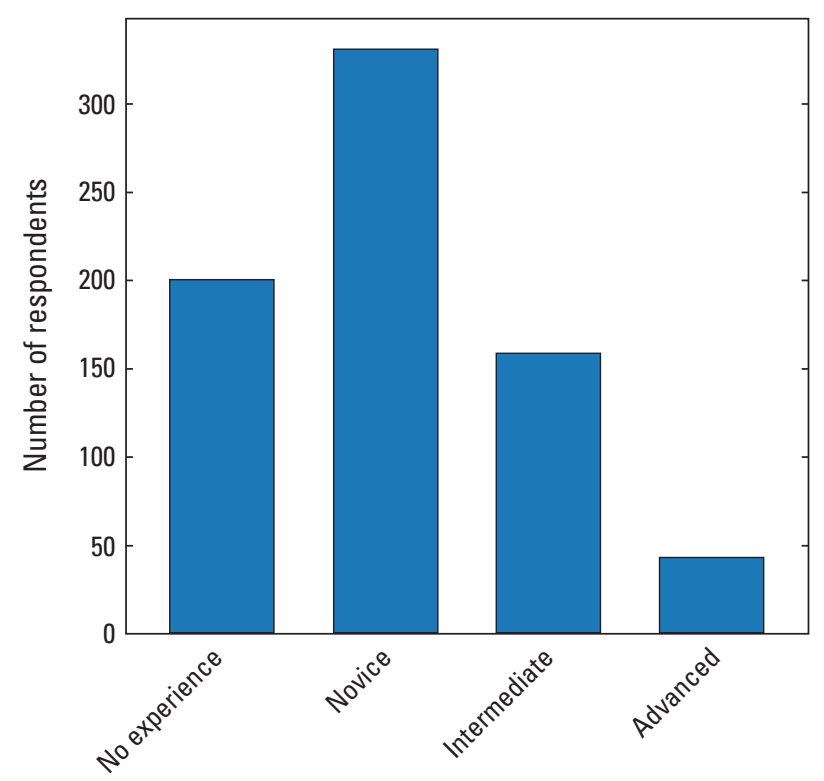

Figure 1.25. Summary of responses to survey question 36 .
037. In what ways have you incorporated decision science into your work?

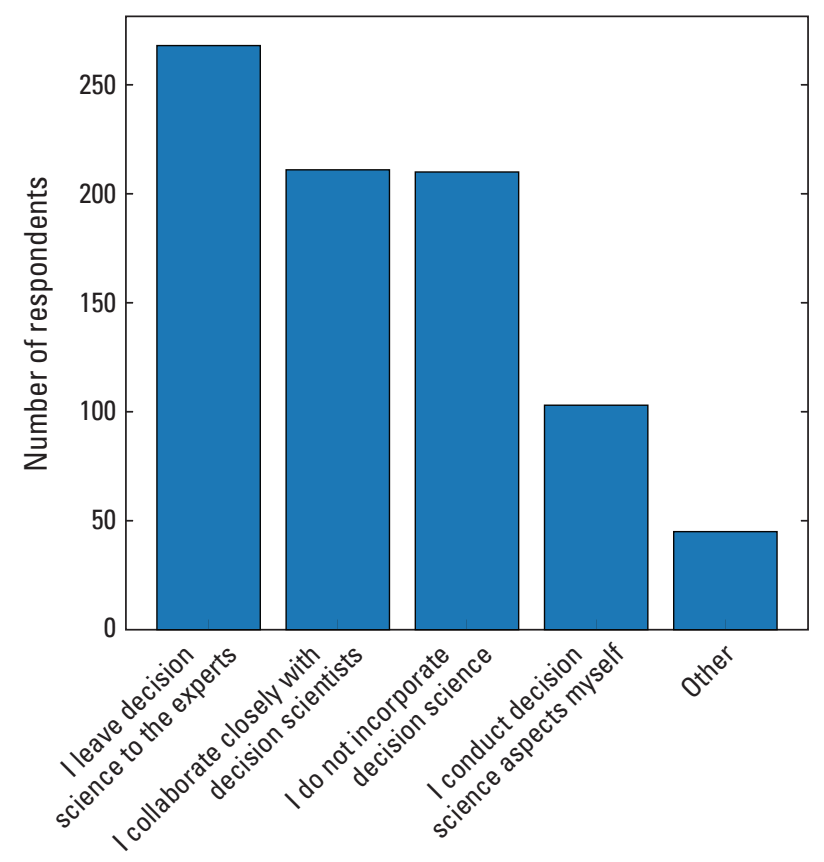

Figure 1.26. Summary of responses to survey question 37. 
038. What science communication approaches are you using to improve information delivery to non-scientific audiences?
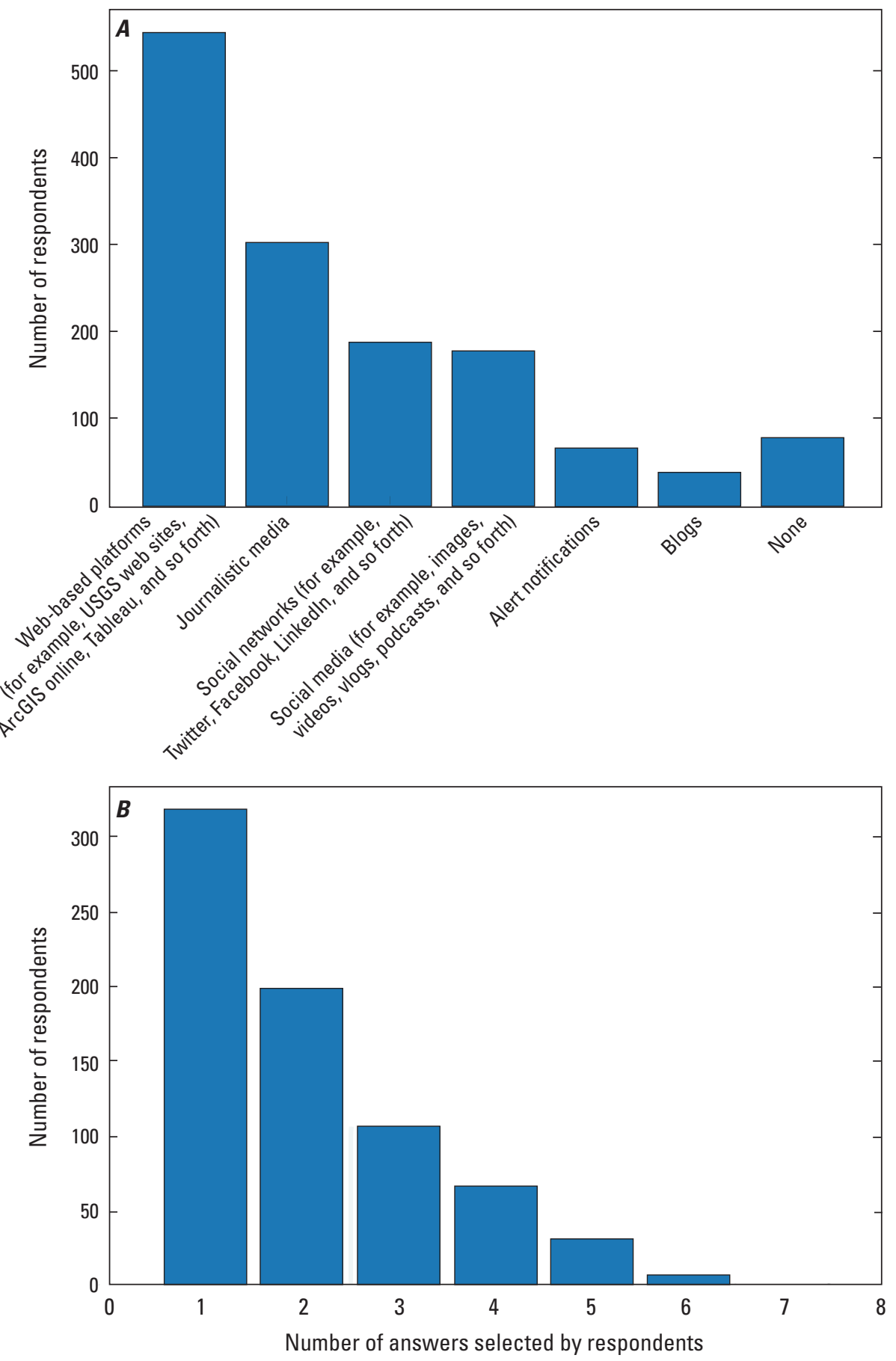

Figure 1.27. Summary of responses to survey question 38 regarding $A$, science communication approaches used to improve information delivery to non-scientific audiences; and $B$, by number of answers selected by respondents Abbreviations: USGS, U.S. Geological Survey. 


\section{Does your project or activity deliver data applications and visualizations on the web?}

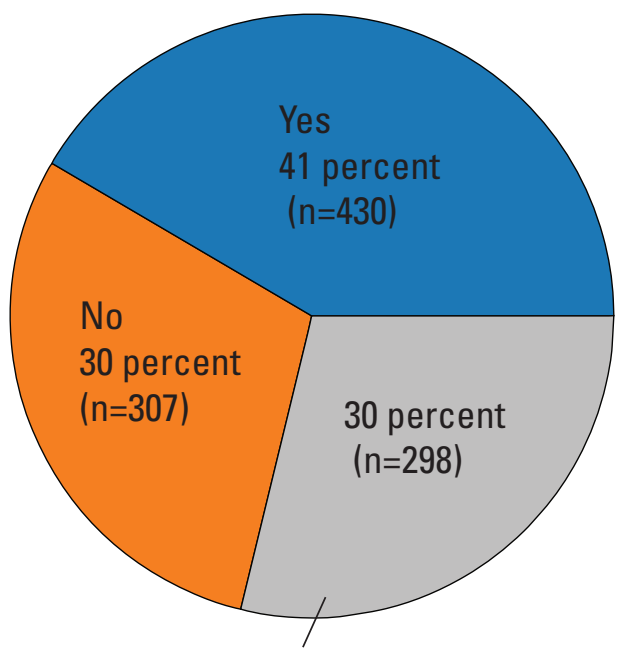

Not applicable (my work does not provide actionable information to decision makers)

Figure 1.28. Summary of responses to survey question 39.

041. What barriers limit your ability to incorporate more stakeholder engagement, decision science, and innovative science communication approaches into your work?

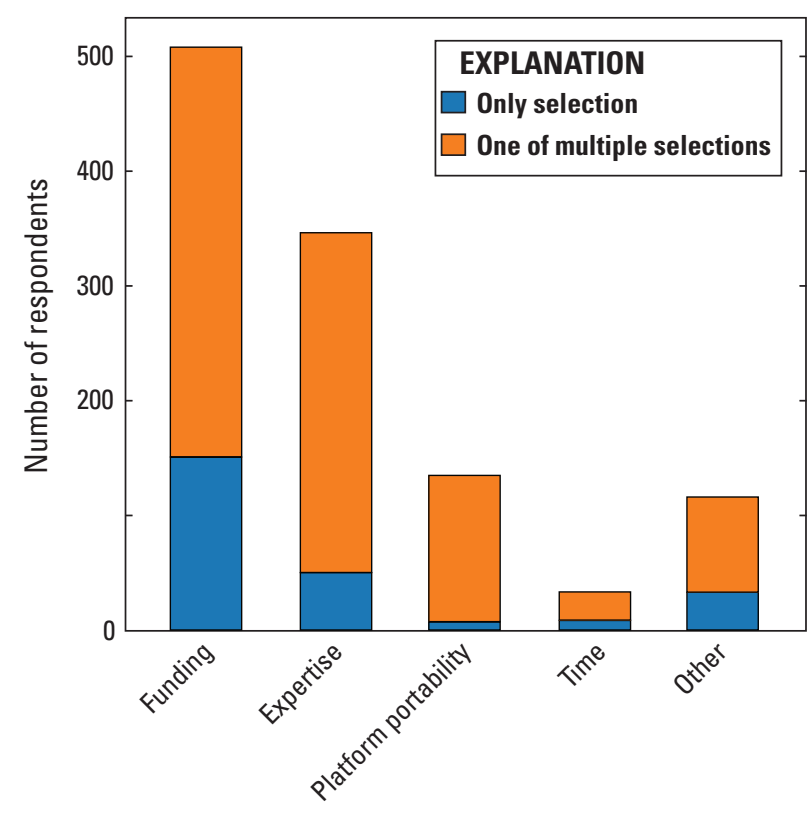

Figure 1.29. Summary of responses to survey question 41.

\section{General}

43. Please provide the names of any Communities of Practice (COPs), workgroups, and collaborations related to data integration, integrated predictive science/ modeling, stakeholder engagement, decision science, or innovative science communication that you are actively involved in (such as, "I regularly attend meetings and the topic is relevant to my past or ongoing work). Examples include USGS Community for Data Integration, Government eDNA Working Group, Earth Science Information Partners, or Satellite Needs Working Group. (narrative text).

44. Many of the previous questions focused on specific areas of expertise. Given the integrated nature of EarthMAP, broad knowledge of activities across the USGS and experience bringing tools, people, and ideas together also is a critical capacity. Please select your degree of experience with these types of activities (for example, integrating data, results, tools, and expertise from multiple disciplines, leading the synthesis of research insights across disciplines, and so forth): (controlled list).

\section{Please select your degree of experience with science integration.}

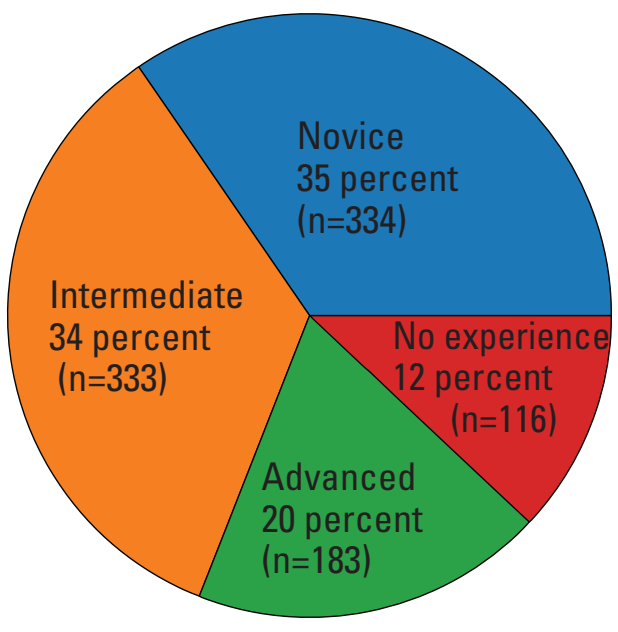

Figure 1.30. Summary of responses to survey question 44. 
穴

ปี

के क

E.

䓂.

$\frac{2}{4} \div$

产 苛

苞

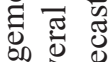

䒕施

$\exists \dot{\square}$

웡 홍

踏

至菅

若 㤩

造

总俅

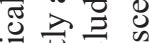

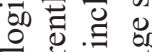

융

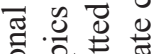

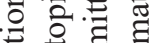

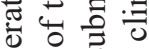

ơ

跑的

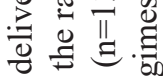

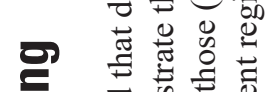

.

क

(0) ส ส

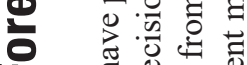

노

ॠ

음

용 워의

요요

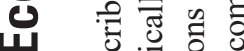

क

증 웧

을 월

क जै

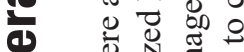

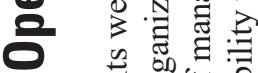

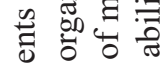

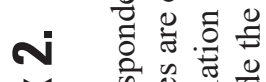

× की

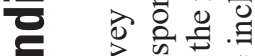

(1)

을 की

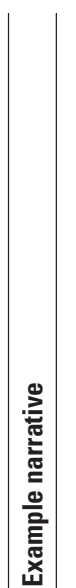

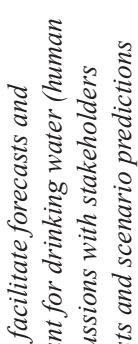

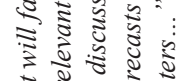

₹

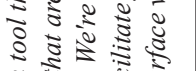

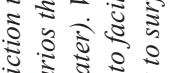

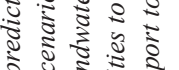

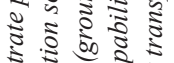

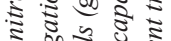

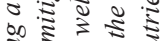

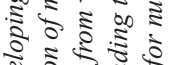

吾要

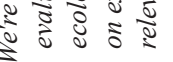

s

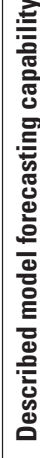

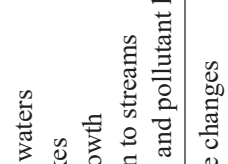

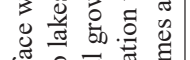

尊

की

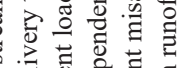

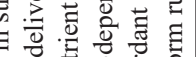

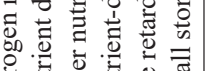

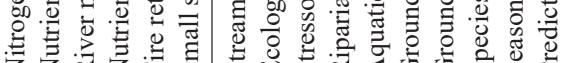

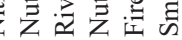

........................

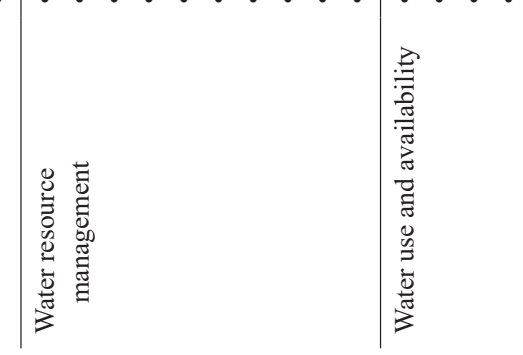




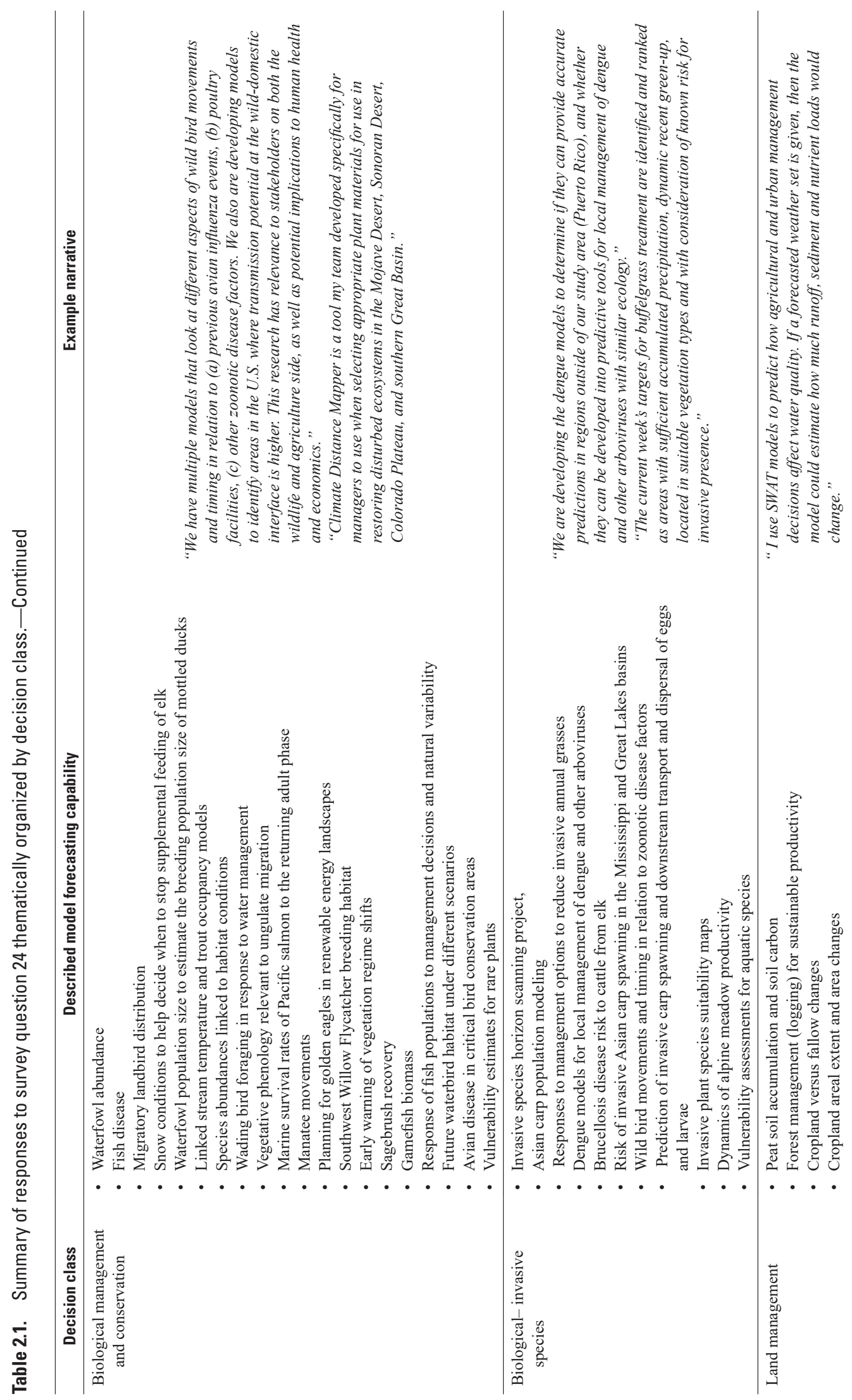




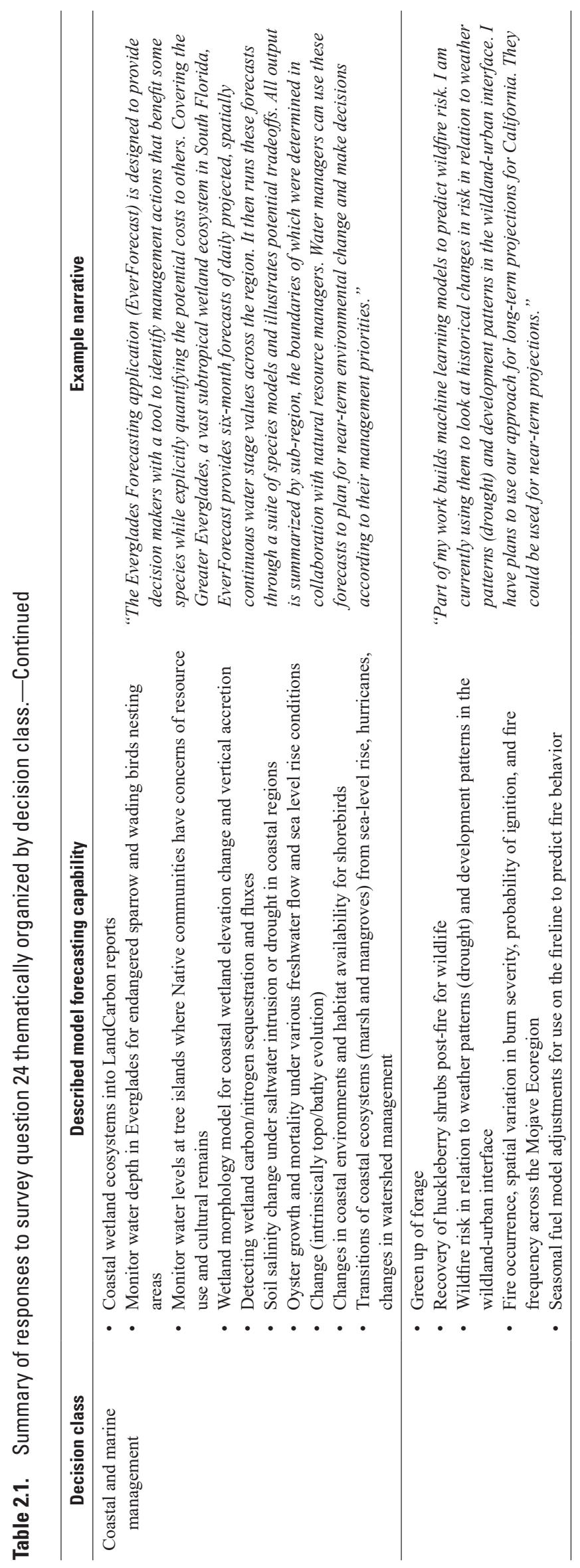




\section{Appendix 3. Submitted and Identified Websites and Data Web Applications}

Survey respondents were asked to describe approaches for information delivery, specifically including data delivery applications and visualizations on the web (questions 38-40), and more than 180 responses received. Responses are organized here thematically by stakeholder decision categories and the type of content. Static content is any content that can be delivered to an end user without having to be generated, modified, or processed. Static content rarely changes and does not depend on user input or preferences. Dynamic content allows the end user to query frequently updated databases. Interactive content allows active engagement by the end user, allowing for more dynamic, custom, and responsive interchange with data and tools. The CAT assigned stakeholder decision categories and content types using professional judgement. Websites were accessible in March 2021 (any submitted but unaccessible Uniform Resource Locators [URLs] were not included herein).

Table 3.1. Summary of survey responses describing approaches for information delivery thematically organized by stakeholder decision category and type of content.

[USGS, U.S. Geological Survey; EPA, U.S. Environmental Protection Agency; FEMA, Federal Emergency Management Agency; NOAA, National Oceanic and Atmospheric Administration

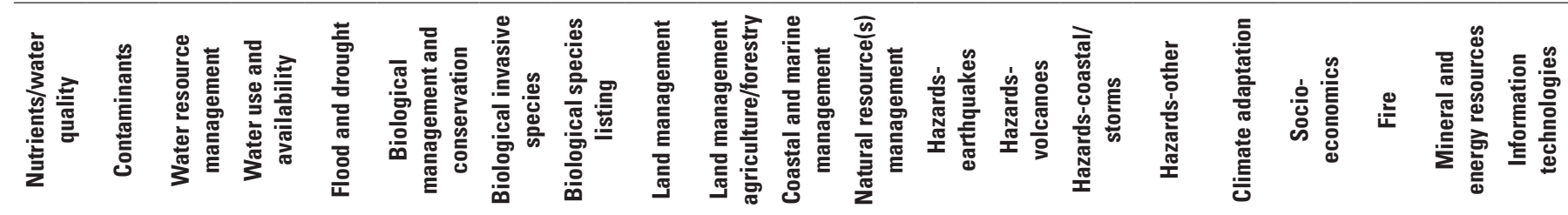

\begin{tabular}{|c|c|c|c|c|c|c|c|c|c|}
\hline$\sqrt{ }$ & $\sqrt{ }$ & $\sqrt{ }$ & & & & & & & \\
\hline \multirow[t]{5}{*}{$\sqrt{ }$} & $\sqrt{ }$ & & & & & & & & \\
\hline & $\sqrt{ }$ & $\sqrt{ }$ & $\sqrt{ }$ & & & & & & \\
\hline & & $\sqrt{ }$ & $\sqrt{ }$ & & & & & & \\
\hline & & $\sqrt{ }$ & $\sqrt{ }$ & & & & & & \\
\hline & & $\sqrt{ }$ & $\sqrt{ }$ & & & & & & \\
\hline$\sqrt{ }$ & & $\sqrt{ }$ & $\sqrt{ }$ & $\sqrt{ }$ & & & & & \\
\hline$\sqrt{ }$ & & $\sqrt{ }$ & $\sqrt{ }$ & $\sqrt{ }$ & & & & $\sqrt{ }$ & \\
\hline$\sqrt{ }$ & $\sqrt{ }$ & $\sqrt{ }$ & $\sqrt{ }$ & & & & & & \\
\hline$\sqrt{ }$ & & $\sqrt{ }$ & $\sqrt{ }$ & & & & & $\sqrt{ }$ & \\
\hline$\sqrt{ }$ & & $\sqrt{ }$ & $\sqrt{ }$ & & & & & $\sqrt{ }$ & \\
\hline \multirow[t]{2}{*}{$\sqrt{ }$} & & $\sqrt{ }$ & $\sqrt{ }$ & & $\sqrt{ }$ & & & $\sqrt{ }$ & \\
\hline & & $\sqrt{ }$ & & $\sqrt{ }$ & $\sqrt{ }$ & $\sqrt{ }$ & $\sqrt{ }$ & $\sqrt{ }$ & $\sqrt{ }$ \\
\hline$\sqrt{ }$ & & $\sqrt{ }$ & $\sqrt{ }$ & $\sqrt{ }$ & $\sqrt{ }$ & & & $\sqrt{ }$ & \\
\hline \multirow[t]{2}{*}{$\sqrt{ }$} & & $\sqrt{ }$ & & & $\sqrt{ }$ & & & & \\
\hline & & $\sqrt{ }$ & & & $\sqrt{ }$ & $\sqrt{ }$ & & $\sqrt{ }$ & \\
\hline
\end{tabular}




\begin{tabular}{|c|c|c|c|c|}
\hline 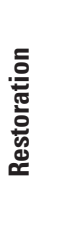 & 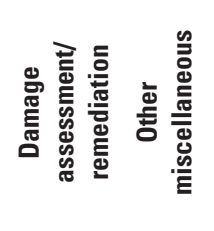 & 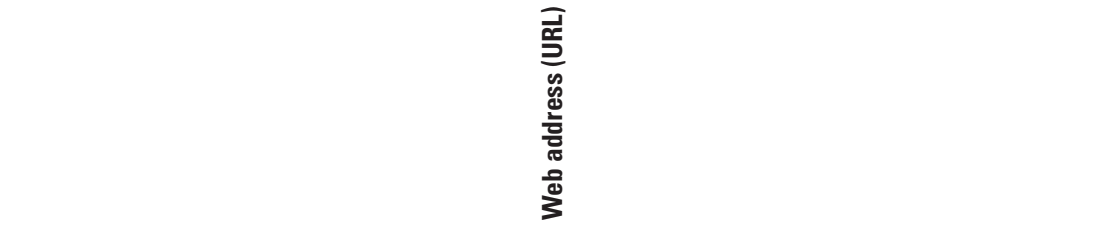 & 离 & 홍 \\
\hline & & https://waterdata.usgs.gov/sd/nwis/current?type=flow\&group_key=basin_cd & Interactive & USGS \\
\hline & & https://fl.water.usgs.gov/mapper/ & Interactive & USGS \\
\hline & & $\begin{array}{l}\text { https://www.epa.gov/water-research/cyanobacteria-assessment-network-cyan\#: :text=Cy } \\
\text { AN\%20is\%20a\%20multi-agency\%20project } \% 20 \text { among } \% 20 \text { EPA } \% 2 \text { C } \% 20 \text { the,to } \% 20 \text { detect } \% 2 \\
\text { 0algal\%20blooms\%20in\%20U.S.\%20freshwater\%20systems }\end{array}$ & Dynamic & EPA \\
\hline & $\sqrt{ }$ & https://code.usgs.gov/water/stats/cyan/tree/v1.0.0 & Static & USGS \\
\hline & & https://play.google.com/store/apps/details?id=com.topcoder.epa\&hl=en_US\&gl=US & Dynamic & EPA \\
\hline & & https://sparrow.wim.usgs.gov/sparrow-northeast-2012/ & Interactive & USGS \\
\hline & & https://chesapeake.usgs.gov/phase6/map/ & Interactive & USGS \\
\hline$\sqrt{ }$ & & $\begin{array}{l}\text { https://www.chesapeakeconservancy.org/conservation-innovation-center/high-resolution-data/ } \\
\text { land-use-data-project/ }\end{array}$ & Static & $\begin{array}{l}\text { Chesapeake } \\
\text { Conservancy }\end{array}$ \\
\hline & & https://mn.water.usgs.gov/projects/bemidji/ & Static & USGS \\
\hline & & $\begin{array}{l}\text { https://www.sciencebase.gov/catalog/item/5910d9b2e4b0e541a03ac976?community=Nationa } \\
\text { 1+Crude+Oil+Spill+Fate+and+Natural+Attenuation+Research+Site }\end{array}$ & Static & USGS \\
\hline & & https://ny.water.usgs.gov/maps/nowcast/ & Dynamic & USGS \\
\hline & & https://wim.usgs.gov/badriver/ & Static & USGS \\
\hline & & $\begin{array}{l}\text { https://webapps.usgs.gov/gwwebflow/?tds_url=https\%3A\%2F\%2Ftxthredds.usgs.gov\%2F\&tds_ } \\
\text { dir=public\%2Fgwwebflow\%2Fviewer\%2F }\end{array}$ & Interactive & USGS \\
\hline & & https://labs-beta.waterdata.usgs.gov/estimated-availability/index.html\#/water-use & Static & USGS \\
\hline & & https://www2.usgs.gov/water/southatlantic/projects/floodplains/ & Interactive & USGS \\
\hline & & https://webapps.usgs.gov/walkerbasinhydromapper/\#home & Interactive & USGS \\
\hline & & $\begin{array}{l}\text { https://www.usgs.gov/centers/co-water/science/water-quality-summaries-several-major-river- } \\
\text { basins-colorado?qt-science_center_objects }\end{array}$ & Static & USGS \\
\hline & & https://webapps.usgs.gov/HDE/SouthernHighPlains/ & Interactive & USGS \\
\hline & & https://txpub.usgs.gov/bellcounty/ & Interactive & USGS \\
\hline & & https://www.gcmrc.gov/discharge_qw_sediment/ & Interactive & USGS \\
\hline & & https://sofia.usgs.gov/eden/models/real-time.php & Interactive & USGS \\
\hline & & https://www2.usgs.gov/water/southatlantic/projects/coastalsalinity/home.php & Interactive & USGS \\
\hline & & https://tableau.usgs.gov/views/Bay_Delta_Portal/MappingSurveys2020?\%3Aembed=yes & Static & USGS \\
\hline$\sqrt{ }$ & & https://umesc.usgs.gov/mapping/west_newton_chute_native_mussel_storymap.html & Interactive & USGS \\
\hline
\end{tabular}


Table 3.1. Summary of survey responses describing approaches for information delivery thematically organized by stakeholder decision category and type of content.-Continued

[USGS, U.S. Geological Survey; EPA, U.S. Environmental Protection Agency; FEMA, Federal Emergency Management Agency; NOAA, National Oceanic and Atmospheric Administration

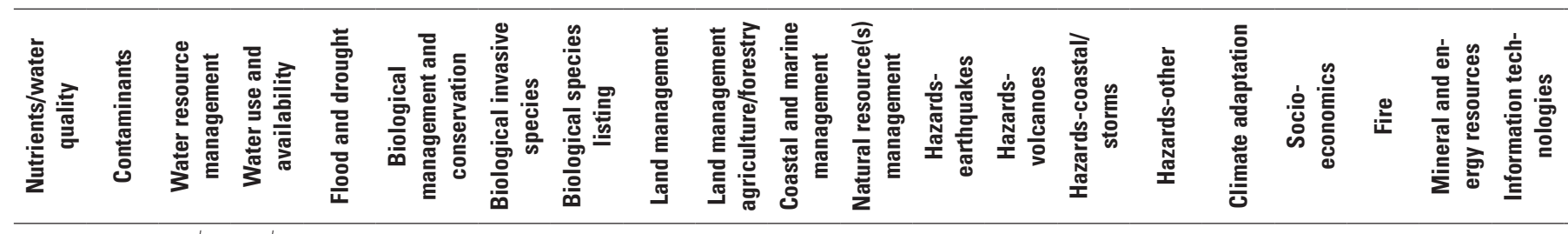

\begin{tabular}{|c|c|c|c|c|c|c|}
\hline & & $\sqrt{ }$ & $\sqrt{ }$ & & & \\
\hline$\sqrt{ }$ & & $\sqrt{ }$ & $\sqrt{ }$ & & & \\
\hline \multirow[t]{5}{*}{$\sqrt{ }$} & & $\sqrt{ }$ & $\sqrt{ }$ & & & \\
\hline & & $\sqrt{ }$ & . & $\sqrt{ }$ & $\sqrt{ }$ & \\
\hline & & $\sqrt{ }$ & $\sqrt{ }$ & $\sqrt{ }$ & $\sqrt{ }$ & \\
\hline & $\sqrt{ }$ & $\sqrt{ }$ & $\sqrt{ }$ & & & $\sqrt{ }$ \\
\hline & & $\sqrt{ }$ & $\sqrt{ }$ & & & \\
\hline$\sqrt{ }$ & & & $\sqrt{ }$ & & & \\
\hline$\sqrt{ }$ & & $\sqrt{ }$ & $\sqrt{ }$ & & & \\
\hline
\end{tabular}

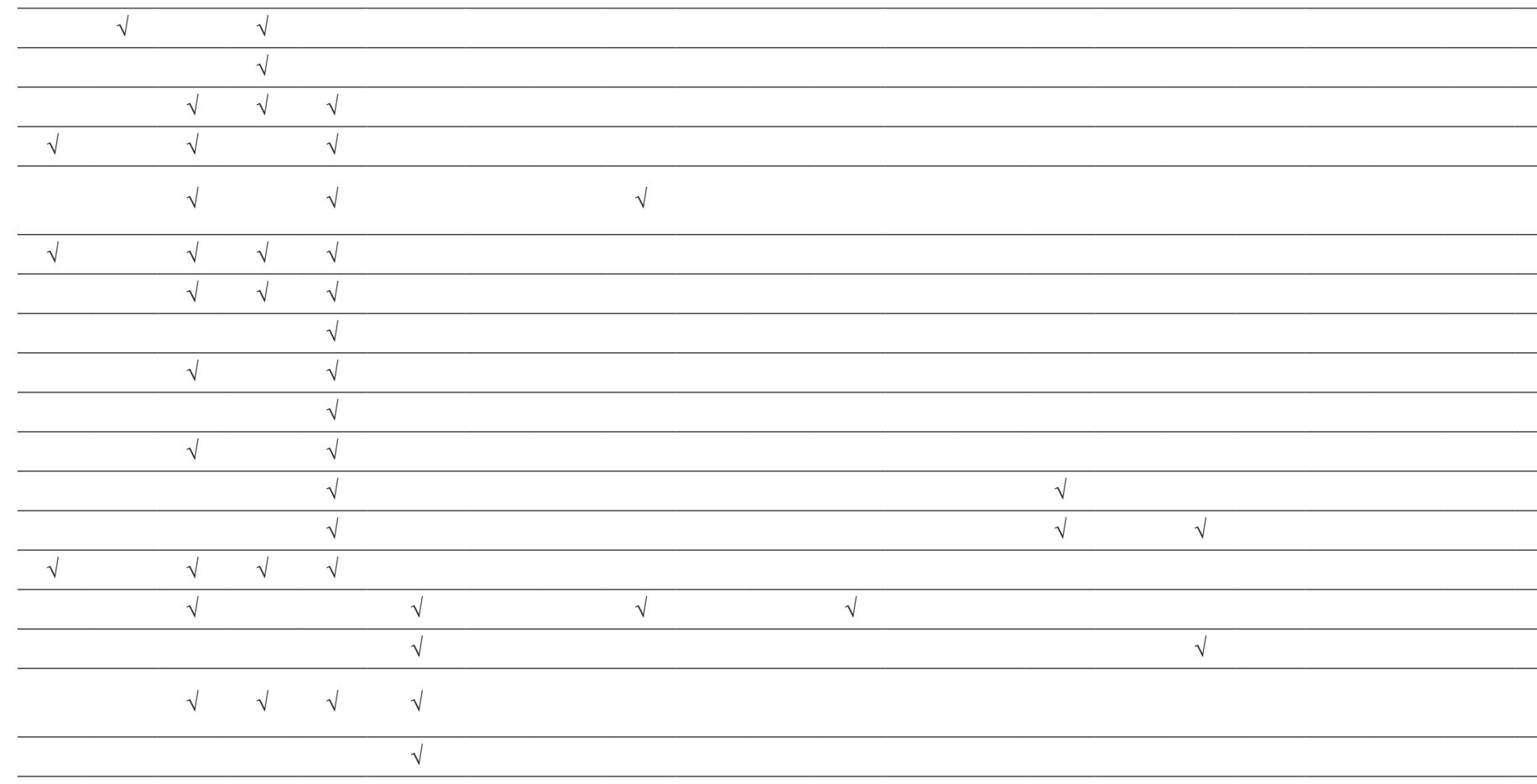




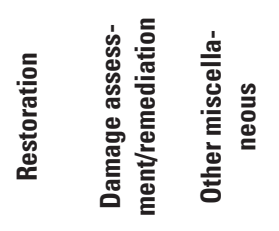
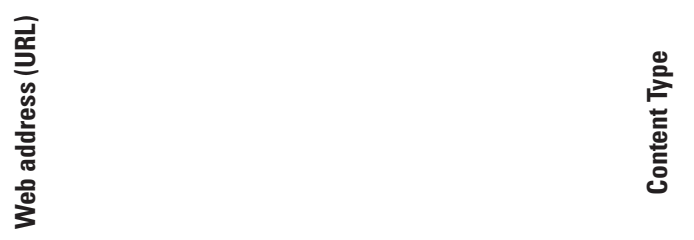

https://labs.waterdata.usgs.gov/estimated-availability/index.html\#/

Static USGS

https://txpub.usgs.gov/houston_subsidence/home/

Interactive

https://nrtwq.usgs.gov/ks/

Dynamic

USGS

$\sqrt{ }$

https://grandcanyon.usgs.gov/gisapps/sandbarphotoviewer/RemoteCameraTimeSeries.html

Interactive

USGS

https://www.usgs.gov/apps/sandbar/

Interactive

USGS

https://webapps.usgs.gov/cogg/

https://ca.water.usgs.gov/projects/USGS-US-domestic-wells.html

Interactive

USGS

https://nawqatrends.wim.usgs.gov/Decadal/

Static

USGS

https://ca.water.usgs.gov/gama/

Interactive

USGS

https://nevada.usgs.gov/doe_nv/

Interactive

USGS

hes.//nevada.usgs.gov/do__n/

Static

USGS

https://www.google.com/search?q=groundwater+conditions+in+georgia\&rlz=1C1GCEA enUS768US768\&oq=gr\&aqs=chrome.3.69i57j69i5913j69i60j69i6112.4718j0j7\&sourceid= chrome \&ie=UTF-8

https:/www.usgs.gov/centers/sa-water/science/groundwater-monitoring-program-albanydougherty-county-area?qt-science_center_objects $=0 \# q t-s c i e n c e$ _center_objects

http://www.manureadvisorysystem.wi.gov/runoffrisk/index

Interactive

USGS

Interactive

Wisconsin

Manure

Management

Advisory

System

(State of

Wisconsin)

https://usgs.maps.arcgis.com/home/item.html?id=3b038837dfe347daa8691931182788f5

USGS

https://pr.water.usgs.gov/drought/hydro_conditions_selected_wells.html

Interactive

USGS

https://waterdata.usgs.gov/ne/nwis/current/?type=flow

Static

USGS

https://webapps.usgs.gov/lake_houston/home/

https://www.usgs.gov/centers/tx-water/science/texas-gulf-coast-groundwater-and-land-

Static

USGS

subsidence-program?qt-science_center_objects=0\#qt-science_center_objects

\begin{tabular}{lcc} 
https://webapps.usgs.gov/lakehoustonmodel/ & Static & USGS \\
https://xpub.usgs.gov/txwaterdashboard/ & Dynamic & USGS \\
https://webapps.usgs.gov/infrm/fdst/ & Interactive & USGS \\
https://webapps.usgs.gov/infrm/estBFE/ & Static & USGS \\
https://msc.fema.gov/portal/home & Static & FEMA \\
https://fim.wim.usgs.gov/fim/ & Dynamic & USGS \\
https://www.usgs.gov/special-topic/hurricane-harvey & Static & USGS \\
https://data.pointblue.org/apps/ocof/cms/ & Interactive & multi-partners \\
\hline https://webapps.usgs.gov/\#page-top & Dynamic & USGS \\
https://wim.usgs.gov/geonarrative/mcweo/ & Static & USGS \\
https://www.sciencebase.gov/catalog/item/5b33be6fe4b040769c172fad & Static & USGS \\
https://www.usgs.gov/mission-areas/water-resources/science/water-data-visualizations?qt- & Static & USGS \\
science_center_objects=0\#qt-science_center_objects & & Static \\
armi.usgs.gov & USGS
\end{tabular}


Table 3.1. Summary of survey responses describing approaches for information delivery thematically organized by stakeholder decision category and type of content.-Continued

[USGS, U.S. Geological Survey; EPA, U.S. Environmental Protection Agency; FEMA, Federal Emergency Management Agency; NOAA, National Oceanic and Atmospheric Administration

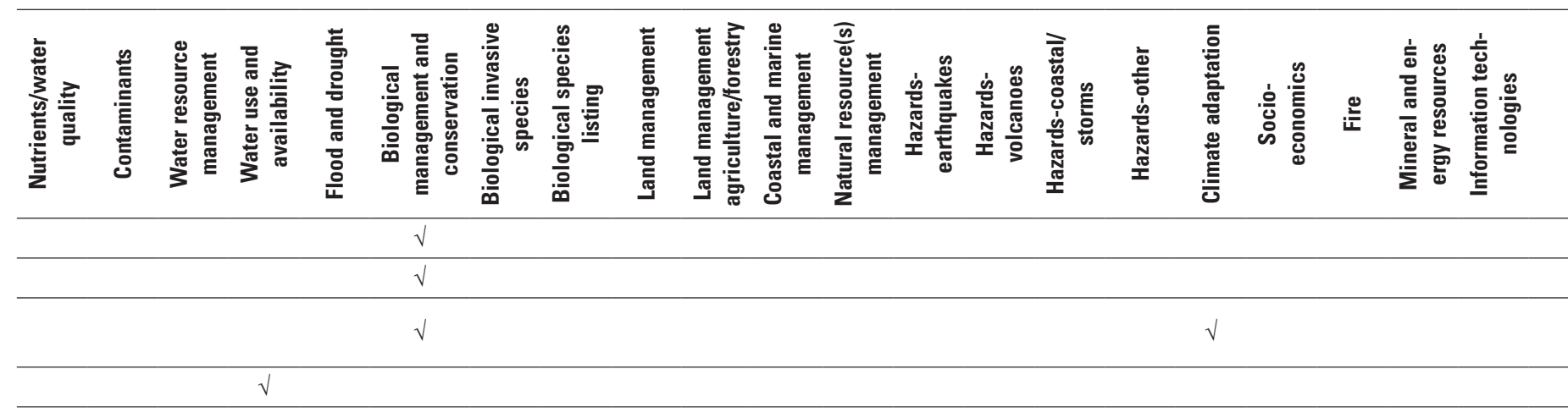

\begin{tabular}{lll}
\hline & & \\
& & \\
\hline$\sqrt{ }$ & $\sqrt{ }$ & $\sqrt{ }$ \\
\hline & $\sqrt{ }$ &
\end{tabular}

$$
\sqrt{ }
$$$$
\sqrt{ }+\sqrt{1}
$$

$\begin{array}{lll}\sqrt{ } & & \\ \sqrt{ } & & \\ \sqrt{ } & \sqrt{ } & \\ \sqrt{ } & \sqrt{ } \\ \sqrt{ } & & \end{array}$

V

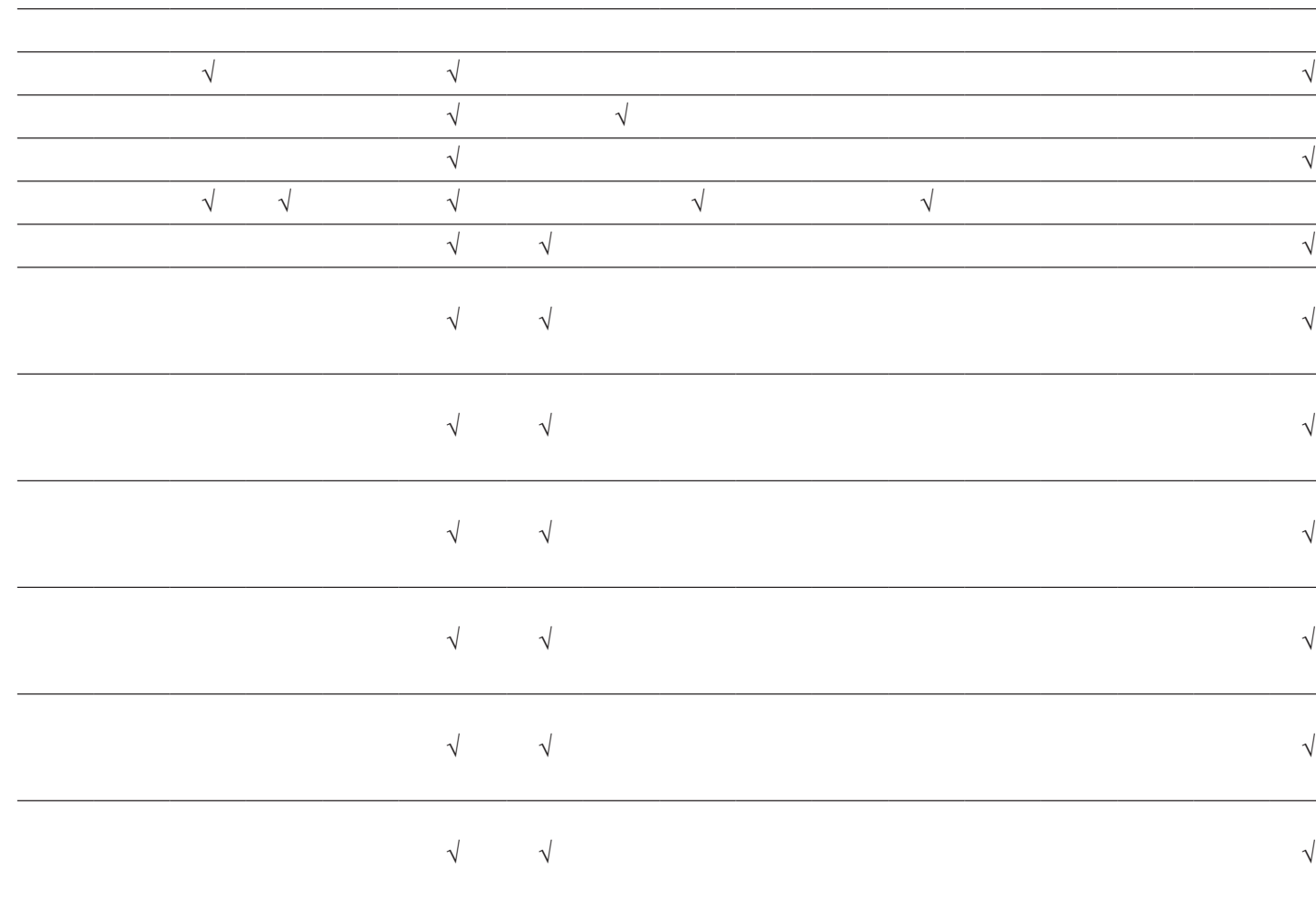

$\sqrt{ }$ 
https://www.usgs.gov/apps/CWD/

Interactive

USGS

https://whispers.usgs.gov

https://www.usgs.gov/centers/powell-ctr/science/forecasting-mosquito-phenology-a-shifting-

Static

USGS

climate-synthesizing?qt-science_center_objects $=0 \#$ qt-science_center_objects

Static USGS

https://labs.waterdata.usgs.gov/visualizations/water-use/index.html

ITIS.gov

Static

USGS

https://oceanexplorer.noaa.gov/explorations/17deepsearch/welcome.html

Interactive international

partnership

https://maps.usgs.gov/nfhp/

Dynamic NOAA Ocean

https://www.sciencebase.gov/drip/

Explorer

http://assessment.fishhabitat.org/

Dynamic USGS

https://www.pwrc.usgs.gov/ai/

https://usgs.maps.arcgis.com/apps/MapJournal/index.html?appid=37f0eacdaccf4c2fbe5f65 $535 \mathrm{ddc} 7 \mathrm{e} 8 \mathrm{c})$

https://www.usgs.gov/apps/Models_web_app/

https://www.wlci.gov/

Static USGS

Static USGS

Static USGS

Static USGS

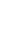

https://eerscmap.usgs.gov/uswtdb/viewer/\#3/37.25/-96.25

https://labs.waterdata.usgs.gov/visualizations/climate-change-walleye-bass/index.html

Dynamic USGS

https://www.plantcam.live/

Static

Interagency

Working

Group

http://avianmalaria.watch/

https://ecosheds.org/

https://pubs.er.usgs.gov/publication/fs20203022

https://www.usanpn.org/data/visualizations

$\begin{array}{cc}\text { Dynamic } & \text { USGS } \\ \text { Static } & \text { USGS }\end{array}$

(1)

https://fws.usanpn.org/valle-de-oro

Static Collaboration

Static

Interactive Collaboration

Static

USGS

Dynamic

National

Phenology

Network

https://www.usanpn.org/agdd_uncertainty

Dynamic

National

Phenology

Network

https://www.usanpn.org/agdd_uncertainty

Dynamic

National

Phenology

Network

https://www.usanpn.org/nn/leaderboard-alltime

Dynamic

National

Phenology

Network

https://www.usanpn.org/data/dashboard

Dynamic

National

Phenology

Network

https://usanpn.org/data/quality

Dynamic

National

Phenology

Network 
Table 3.1. Summary of survey responses describing approaches for information delivery thematically organized by stakeholder decision category and type of content.-Continued

[USGS, U.S. Geological Survey; EPA, U.S. Environmental Protection Agency; FEMA, Federal Emergency Management Agency; NOAA, National Oceanic and Atmospheric Administration

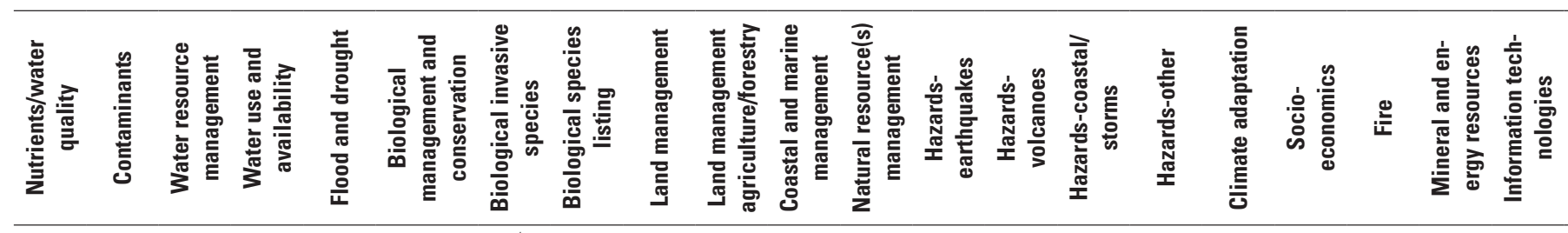

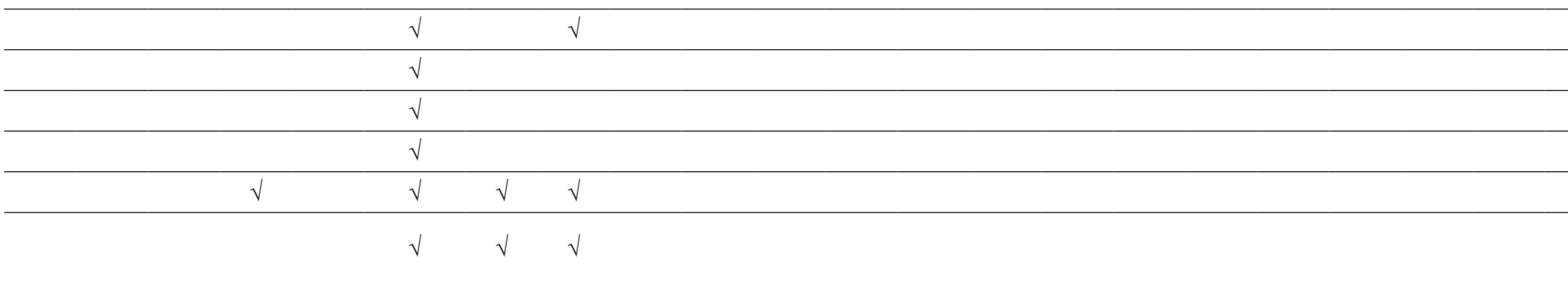

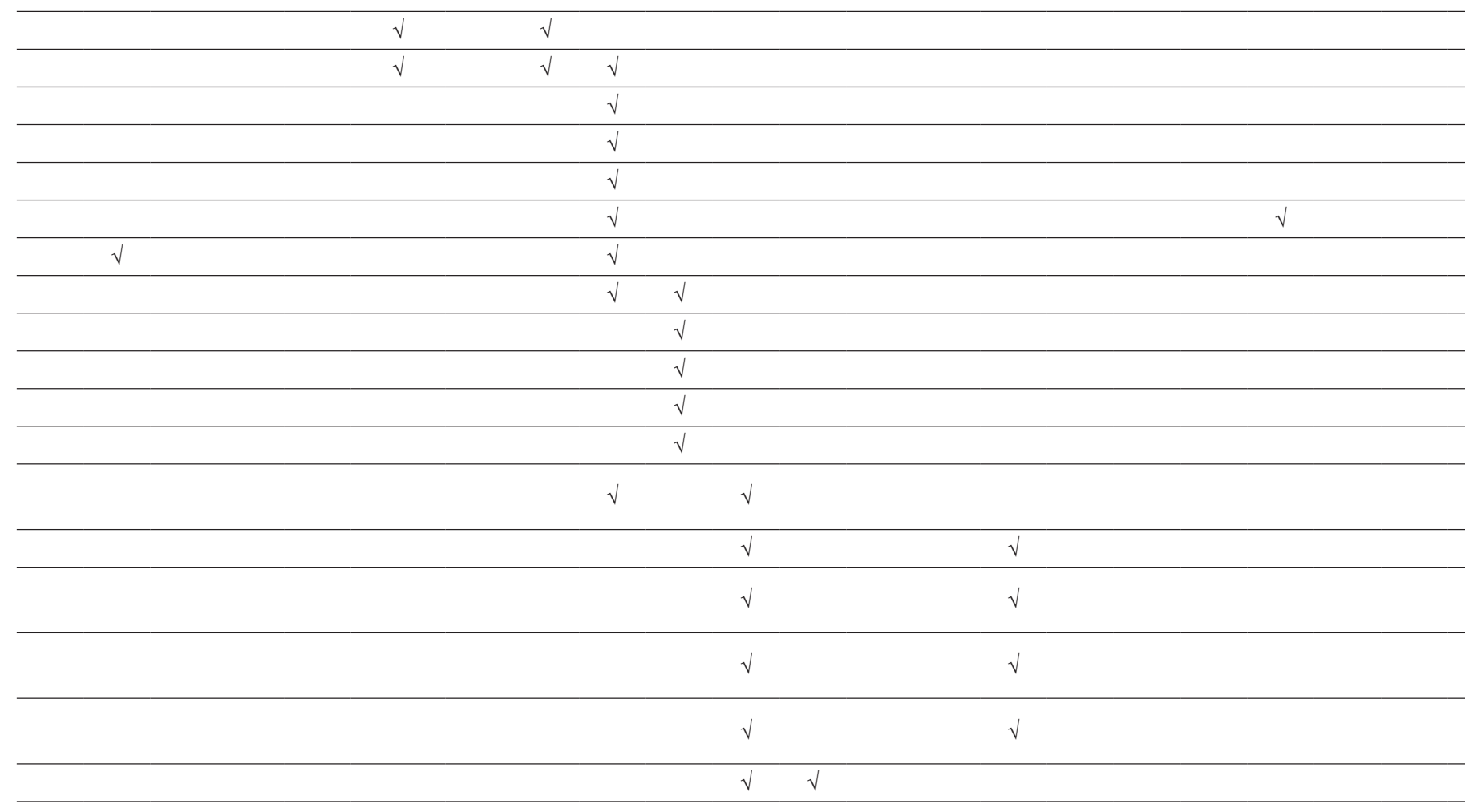




\begin{tabular}{|c|c|c|c|c|}
\hline 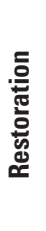 & 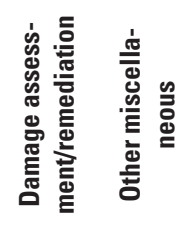 & 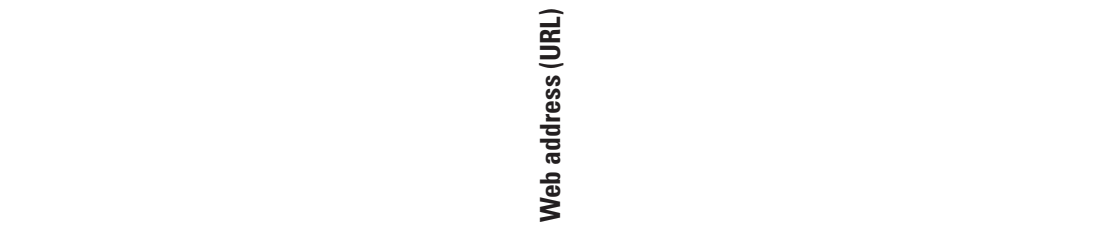 & 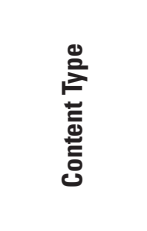 & 홍 \\
\hline & & https://nas.er.usgs.gov/viewer/omap.aspx & Interactive & USGS \\
\hline & & https://nas.er.usgs.gov/AlertSystem/default.aspx & Interactive & USGS \\
\hline & & https://nas.er.usgs.gov/graphs/default.aspx & Interactive & USGS \\
\hline & & https://il.water.usgs.gov/data/Fish_Tracks_Real_Time/ & Static & USGS \\
\hline & & https://gis.usgs.gov/inhabit/ & Dynamic & USGS \\
\hline & & http://www.glfc.org:3838/slcp/ & Dynamic & $\begin{array}{c}\text { Great Lakes } \\
\text { Fisheries } \\
\text { Commission }\end{array}$ \\
\hline & & https://www.usgs.gov/apps/MOViE/ & Interactive & USGS \\
\hline & & www.mbr-pwrc.usgs.gov/software & Static & USGS \\
\hline & & www.mbr-pwrc.usgs.gov & Interactive & USGS \\
\hline & & https://chesapeake.usgs.gov/fishforecast/ & Static & USGS \\
\hline & & https://chesapeake.usgs.gov/shenandoah_groundwater/ & Static & USGS \\
\hline & & $\begin{array}{l}\text { https://www.usgs.gov/centers/cba/science/effects-introduced-species-native-brook-trout-a-guide- } \\
\text { scientific-literature }\end{array}$ & Static & USGS \\
\hline & & https://www.monitoringresources.org/ & Static & $\begin{array}{l}\text { Pacific } \\
\text { Northwest } \\
\text { Aquatic } \\
\text { Monitoring } \\
\text { Partnership }\end{array}$ \\
\hline & & https://sciencebase.usgs.gov/nabat/\#/home & Dynamic & USGS \\
\hline & & https://apps.usgs.gov/gsgbib/index.php & Static & USGS \\
\hline & & https://ltdl.wr.usgs.gov/ & Dynamic & USGS \\
\hline & & https://www.usgs.gov/centers/fresc/science/land-treatment-exploration-tool & Dynamic & USGS \\
\hline & & https://doi.org/10.5066/P98OBOLS & Static & USGS \\
\hline & & https://doi.org/10.5066/P9Z2VVRT & Static & USGS \\
\hline & & https://wim.usgs.gov/geonarrative/dmp/ & Static & USGS \\
\hline & & https://lpdaac.usgs.gov/news/release-of-gfsad-30-meter-cropland-extent-products/ & Interactive & USGS \\
\hline & & https://lpdaac.usgs.gov/products/ghisaconusv001/ & Interactive & USGS \\
\hline & & www.usgs.gov/wgsc/gfsad30 & Static & USGS \\
\hline & & www.usgs.gov/WGSC/GHISA & Static & USGS \\
\hline & & www.usgs.gov/WGSC/GCWP & Static & USGS \\
\hline & & $\begin{array}{l}\text { https://www.usgs.gov/news/moving-mountains-elwha-river-still-changing-five-years-after-world- } \\
\text { s-largest-dam-removal }\end{array}$ & static & USGS \\
\hline & & https://coastal.er.usgs.gov/hurricanes/research/twlviewer/ & dynamic & USGS \\
\hline & & $\begin{array}{l}\text { https://usgs.maps.arcgis.com/apps/MapSeries/index.html?appid=4d000c28c9ac4729920db2 } \\
\text { a97363e8d8 }\end{array}$ & static & USGS \\
\hline & & $\begin{array}{l}\text { https://www.usgs.gov/natural-hazards/coastal-marine-hazards-and-resources/science/coastal- } \\
\text { change-hazards?qt-science_center_objects=0\#qt-science_center_objects }\end{array}$ & static & USGS \\
\hline & & $\begin{array}{l}\text { https://www.usgs.gov/centers/spcmsc/science/coastal-sediment-availability-and-flux-csaf?qt- } \\
\text { science_center_objects=0\#qt-science_center_objects }\end{array}$ & static & USGS \\
\hline$\sqrt{ }$ & & https://www2.usgs.gov/water/southatlantic/projects/floodplains/ & dynamic & USGS \\
\hline
\end{tabular}


Table 3.1. Summary of survey responses describing approaches for information delivery thematically organized by stakeholder decision category and type of content.-Continued

[USGS, U.S. Geological Survey; EPA, U.S. Environmental Protection Agency; FEMA, Federal Emergency Management Agency; NOAA, National Oceanic and Atmospheric Administration

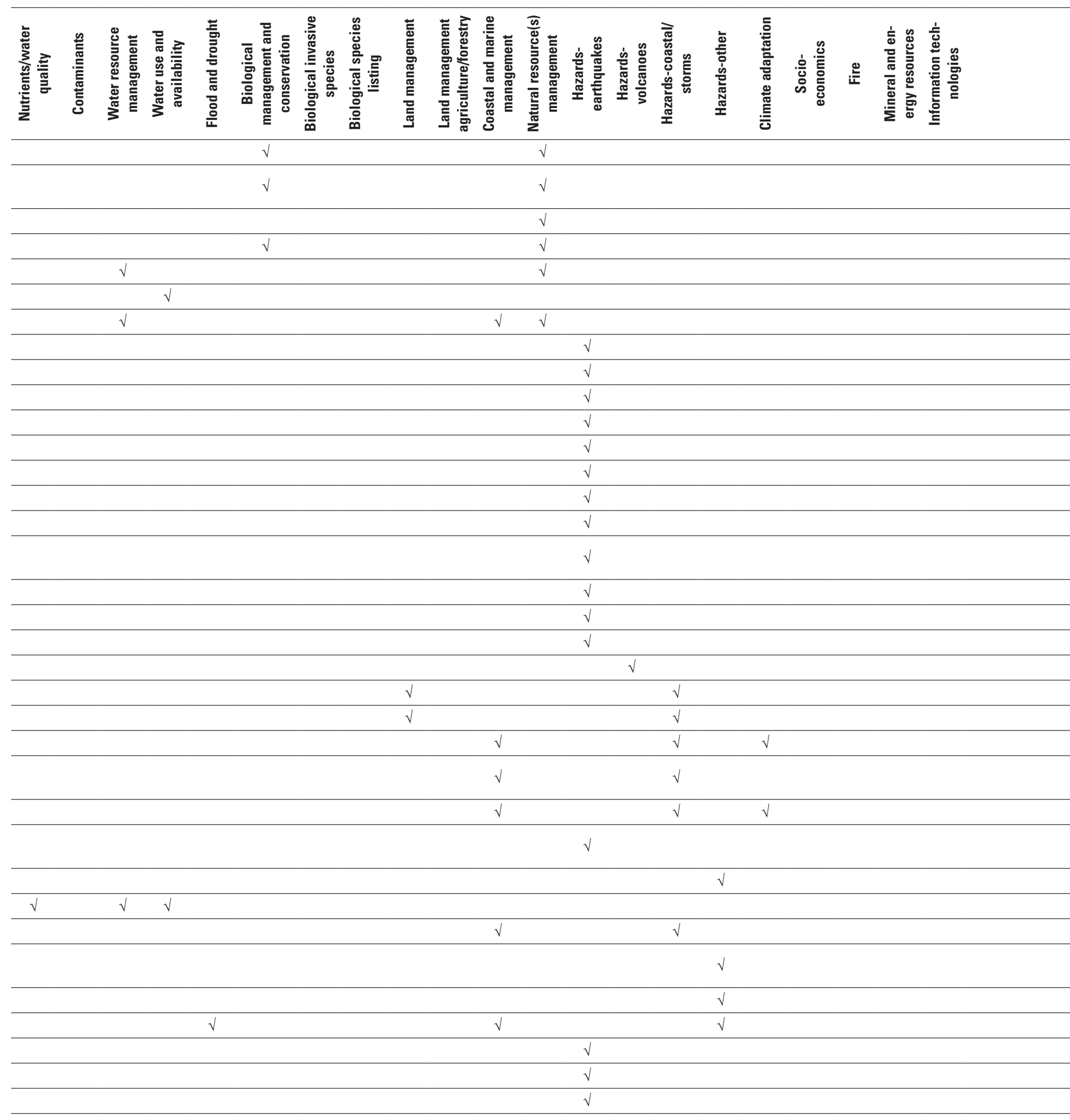



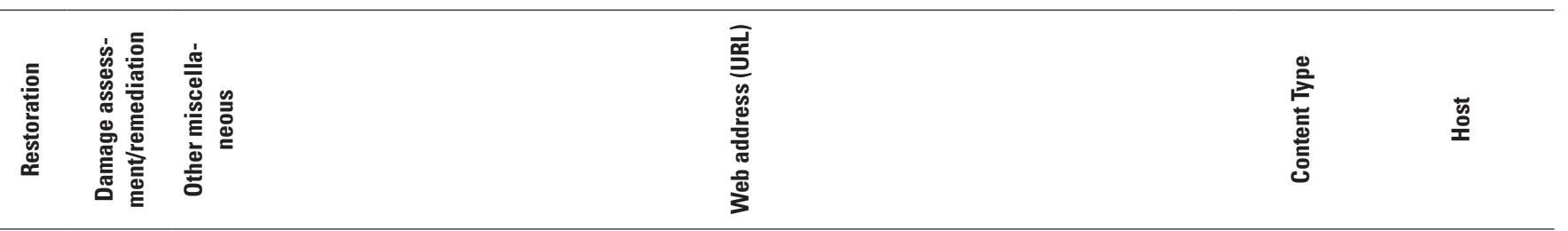

https://warcapps.usgs.gov/gs-eco/warc/ploidy/

https://wolf.org/wolf-info/basic-wolf-info/in-depth-resources/scientific-publications/

dynamic

USGS

thes//whispers.usgsgov

https://whispers.usgs.gov

static International

https://www.usgs.gov/centers/nwhc

dynamic USGS

https://xpub.usgs.gov/maps/EdwardsTrinityGeology/

static

https://va.water.usgs.gov/webmap/Fauquier/

static

https://www.usgs.gov/core-science-systems/ngp/tnm-delivery/

dynamic USGS

hitps./mww.usgs.gov/core-science-systens/ngp/tnm-delivery/

dynamic USGS

https://earthquake.usgs.gov/nshmp/ncm/

static USGS

https://www.usgs.gov/natural-hazards/earthquake-hazards/hazards

static USGS

https://earthquake.usgs.gov/data/oaf/

static

https://earthquake.usgs.gov/earthquakes/eventpage/ci38695658/shake-alert

dynamic

https://earthquake.usgs.gov/earthquakes/map

dynamic

https://earthquake.usgs.gov/earthquakes/eventpage/us1000hyfh/ground-failure/summary

dynamic

https://earthquake.usgs.gov/data/ground-failure/background.php

https:/earthquake.usgs.gov/earthquakes/eventpage/us6000c9hg/executive

dynamic

static

https://earthquake.usgs.gov/earthquakes/map/?extent=-58.44773,-273.86719\&extent=82.49482, 83.67188

https://earthquake.usgs.gov/earthquakes/feed/

https://earthquake.usgs.gov/hazards/interactive/

dynamic

USGS

https://dev-earthquake.cr.usgs.gov/nshmp/

https://www.avo.alaska.edu/activity/Semisopochnoi.php

https://topotools.cr.usgs.gov/topobathy_viewer/

https://topochange.cr.usgs.gov/topochange_viewer/viewer.htm

dynamic

USGS

https://marine.usgs.gov/coastalchangehazardsportal/

\begin{tabular}{cc} 
static & USGS \\
\hline interactive & USGS \\
\hline interactive & USGS \\
\hline dynamic & USGS \\
\hline static & USGS \\
\hline static & USGS \\
\hline dynamic & USGS \\
static & USGS
\end{tabular}

https://www.usgs.gov/centers/spcmsc/science/operational-total-water-level-and-coastal-change-

forecasts?qt-science_center_objects=0\#qt-science_center_objects

https://wim.usgs.gov/geonarrative/cch-rtstorms/

https://www.usgs.gov/natural-hazards/science-application-risk-reduction/science/haywiredscenario?qt-science_center_objects $=0 \# q$ t-science_center_objects

https://www.usgs.gov/natural-hazards/landslide-hazards/monitoring

https://webapps.usgs.gov/

\begin{tabular}{cc} 
static & USGS \\
static & USGS \\
& \\
static & USGS \\
\hline static & USGS \\
dynamic & USGS \\
\hline
\end{tabular}

https://communities.geoplatform.gov/shira/

static

Department of

https://pubs.er.usgs.gov/publication/sim3443

the Interior

https://www.usgs.gov/centers/pcmsc/science/value-us-coral-reefs-risk-reduction

static USGS

https://doi.org/10.5066/P9NT3NRE

static

USGS

https://earthquake.usgs.gov/ws/designmaps/

static

USGS

https://earthquake.usgs.gov/designmaps/rtgm/

static

USGS

dynamic

USGS 
Table 3.1. Summary of survey responses describing approaches for information delivery thematically organized by stakeholder decision category and type of content.-Continued

[USGS, U.S. Geological Survey; EPA, U.S. Environmental Protection Agency; FEMA, Federal Emergency Management Agency; NOAA, National Oceanic and Atmospheric Administration

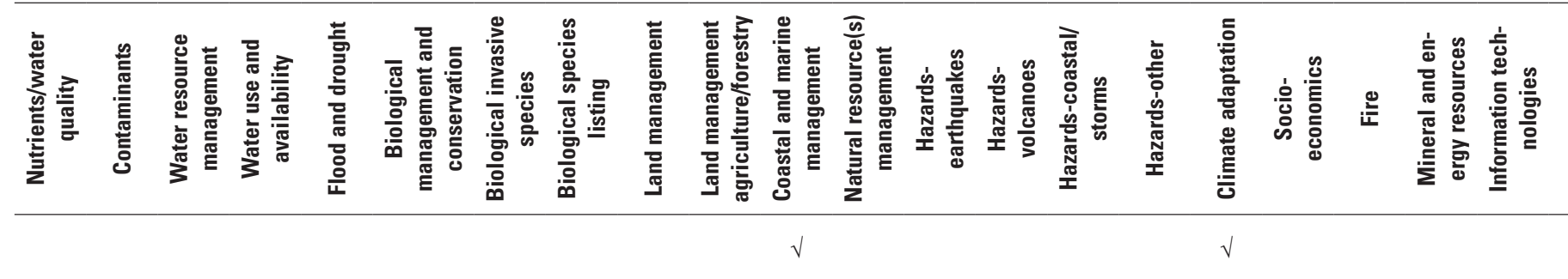

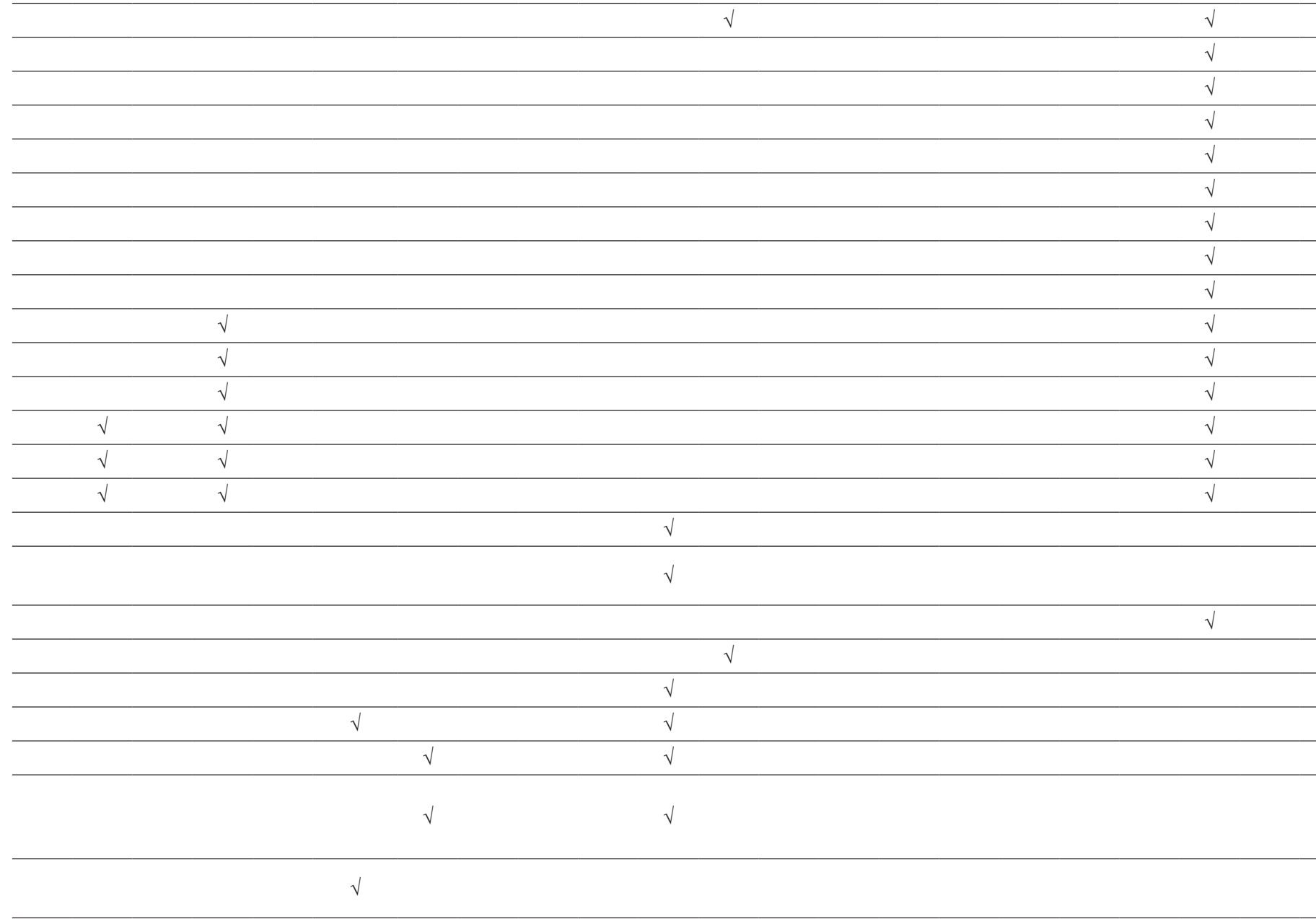



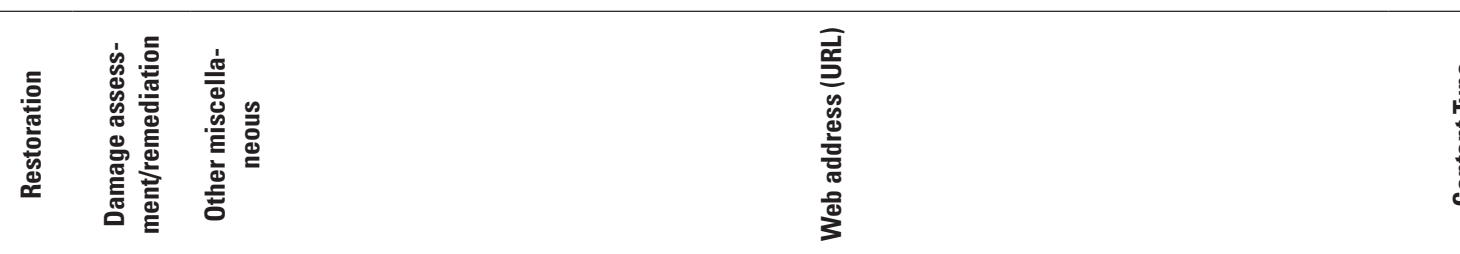

https://usfs.maps.arcgis.com/apps/MapSeries/index.html?appid=0d307a8271a24fe69111a7 $968 \mathrm{bf} 14 \mathrm{f} 37$

https://data.pointblue.org/apps/autowater/

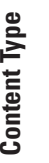

http://aries.integratedmodelling.org/

https://www.landfire.gov/viewer/

https://landfire.gov/about.php\#communication

https://alaska.usgs.gov/science/geology/state_map/interactive_map/AKgeologic_map.html

https://www.usgs.gov/centers/nmic/cement-statistics-and-information

https://www.usgs.gov/centers/nmic/garnet-statistics-and-information

https://www.usgs.gov/centers/nmic/industrial-diamond-statistics-and-information

https://www.usgs.gov/centers/nmic/soda-ash-statistics-and-information

https://www.usgs.gov/centers/nmic/graphite-statistics-and-information

https://www.usgs.gov/centers/nmic/gemstones-statistics-and-information

https://www.usgs.gov/centers/nmic/perlite-statistics-and-information

https://www.usgs.gov/centers/nmic

https://webapps.usgs.gov/uraniummap/map.html

https://or.water.usgs.gov/projs_dir/cpras/

https://www.usgs.gov/media/videos/3-d-geologic-model-columbia-plateau-aquifer-system

https://webapps.usgs.gov/cogg/findings/salinity-within-geologic-formations

https://webapps.usgs.gov/cogg/model/model.twig

https://www.sciencebase.gov/catalog/item/5a0c9dfae4b09af898cd42ad

https://lacoast.gov/crms/

https://www.usgs.gov/centers/wetland-and-aquatic-research-center-warc/science/geospatiallyenabled-web-based-habitat?qt-science_center_objects $=0 \#$

https://sciencebase.usgs.gov/smartenergy

https://www.usgs.gov/apps/sbsc-historical-photos/sites/

https://glcwra.wim.usgs.gov/

https://wim.usgs.gov/phragmites/

https://www.usgs.gov/media/videos/phragmites-adaptive-management-framework-pamf

https://www.greatlakesphragmites.net/pamf/

$\sqrt{ }$

https://usgs.maps.arcgis.com/apps/webappviewer/index.html?id=0fea104260ef465fbd53b6 $9 \mathrm{~b} 25 \mathrm{a} 2 \mathrm{a} 5 \mathrm{f} 9$

\begin{tabular}{cc} 
static & $\begin{array}{c}\text { U.S. Forest } \\
\text { Service }\end{array}$ \\
\hline dynamic & $\begin{array}{c}\text { pointblue. } \\
\text { org; multi- } \\
\text { collaborator }\end{array}$ \\
\hline dynamic & $\begin{array}{c}\text { pointblue. } \\
\text { org; multi- } \\
\text { collaborator }\end{array}$ \\
\hline dynamic & United Nations \\
\hline interactive & $\begin{array}{c}\text { Federal col- } \\
\text { laboration } \\
\text { landfire.gov }\end{array}$ \\
&
\end{tabular}

interactive Federal col-

laboration

landfire.gov

\begin{tabular}{cc} 
static & USGS \\
static & USGS \\
\hline static & USGS \\
\hline static & USGS \\
\hline static & USGS \\
static & USGS \\
\hline static & USGS \\
\hline static & USGS \\
\hline static & USGS \\
\hline dynamic & USGS \\
\hline static & USGS \\
\hline static & USGS \\
\hline static & USGS \\
\hline static & USGS \\
\hline static & USGS \\
\hline interactive & USGS \\
\hline static & USGS \\
& \\
\hline dynamic & USGS \\
\hline static & USGS \\
\hline static & USGS \\
\hline dynamic & USGS \\
\hline static & USGS \\
\hline static & Great Lakes \\
& Phragmites \\
\hline dynamic & USGS \\
\hline & \\
\hline & \\
\hline
\end{tabular}


Table 3.1. Summary of survey responses describing approaches for information delivery thematically organized by stakeholder decision category and type of content.-Continued

[USGS, U.S. Geological Survey; EPA, U.S. Environmental Protection Agency; FEMA, Federal Emergency Management Agency; NOAA, National Oceanic and Atmospheric Administration

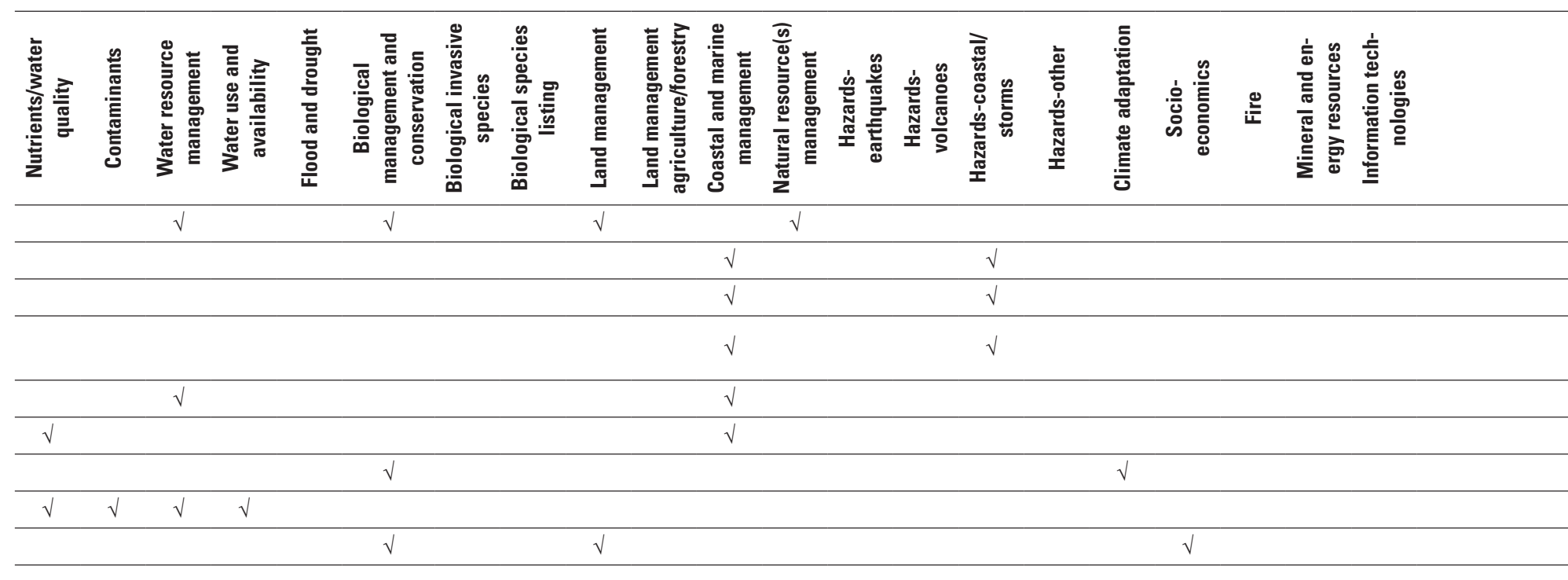




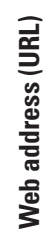

$\stackrel{\overline{\mathbf{s}}}{\mathbf{x}}$

\begin{tabular}{|c|c|c|c|}
\hline$\sqrt{ }$ & https://www.jem.gov/Modeling & interactive & USGS \\
\hline$\sqrt{ }$ & https://wim.usgs.gov/geonarrative/ficc/ & static & USGS \\
\hline$\sqrt{ }$ & https://wim.usgs.gov/geonarrative/cch-ourcoasts/ & static & USGS \\
\hline \multirow[t]{3}{*}{$\sqrt{ }$} & $\begin{array}{l}\text { https://www.usgs.gov/center-news/usgs-provides-rapid-post-hurricane-isaias-coastal-change- } \\
\text { data-assist-national-park?qt-news_science_products=1\#qt-news_science_products }\end{array}$ & static & USGS \\
\hline & https://ny.water.usgs.gov/maps/sser/ & dynamic & USGS \\
\hline & https://www.usgs.gov/media/images/liqwids-mapper-water-quality-data-long-island-ny & static & USGS \\
\hline \multirow[t]{3}{*}{$\sqrt{ }$} & https://usgs-werc-shinytools.shinyapps.io/Climate_Distance_Mapper & interactive & USGS \\
\hline & https://webapps.usgs.gov/rsqa/\#!/ & dynamic & USGS \\
\hline & https://sciencebase.usgs.gov/benefit-transfer/ & dynamic & USGS \\
\hline
\end{tabular}




\section{Appendix 4. Multidisciplinary Projects}

Survey respondents were asked whether they had conducted multidisciplinary efforts to build capacities with scientists from multiple mission areas and were invited to provide Uniform Resource Locators (URLs) linking to those efforts. Project information was provided by 153 respondents. Submitted information was compiled in an Excel spreadsheet that contains the collaborating mission areas and programs identified by the respondent from a controlled list and the respondents' narrative input. In addition, the spreadsheet contains the results of a preliminary analysis to identify "Core" (that of the respondent) and "Integration" disciplines and associated skills and capabilities.

\section{Abbreviations}

ACF

ACIO

AFCEC

AGU

Al

$\mathrm{Al} / \mathrm{ML}$

AK

APEX

API

ARMI

CAWSC

CDI

CHS

CMAO

COAWST

CONED

CONUS

COP

CoSMOS

DNA

DOE

DOI
Apalachicola-Chattahoochee-Flint River Basin

Associate Chief Information Officer

Air Force Civil Engineer Center

American Geophysical Union

Artificial Intelligence

Artificial Intelligence/Machine Learning

Alaska

Agricultural Policy/Environmental eXtender model

Application Program Interface

Amphibian Research and Monitoring Initiative

California Water Science Center

Community for Data Integration

Cloud Hosting Solutions

Community Multiscale Air Quality Modeling System

Coupled-0cean-Atmosphere-Wave-Sediment Transport Modeling System

Coastal National Elevation Database

Applications Project

Contiguous U.S. and District of Columbia

Community of Practice

Coastal Storm Modeling System

deoxyribonucleic acid

Department of Energy

Digital Object Identifier Registry
eDNA

$\mathrm{EH}$

EM

EMA

EMIT

EOF

ESA

FGDC

FOIA

FORT

FRESC

FWS

GGGSC

GIS

GLRI

GMEG

GW

GWRP

HABs

HEC-HMS

HSPF

IAV

IBWC

ICP-MS

ID-WSC

IfSAR

IIDD

ITIS

IWAAs

MA

$\mathrm{MeHg}$ environmental DNA

USGS Environmental Health Program

Energy and Minerals Mission Area

Ecosystems Mission Area

Earth Surface Mineral Dust Source Investigation

Edge of Field

Endangered Species Act

Federal Geographic Data Committee

Freedom of Information Act

U.S. Geological Survey Fort Collins Science Center

Forest and Rangeland Ecosystem Science Center

U.S. Fish and Wildlife Service

Geology, Geophysics, and Geochemistry

Science Center

Geographic Information System

Great Lakes Restoration Initiative

Geology, Minerals, Energy, and Geophysics Science Center

groundwater

Groundwater Resources Program

Harmful Algal Blooms

U.S. Army Corps of Engineers Hydrologic

Engineering Center Hydrologic Modeling

System

Hydrologic Simulation Program-Fortran

invasive aquatic vegetation

International Boundary and Water Commission

Inductively coupled plasma mass spectrometry

Idaho Water Science Center

Interferometric Synthetic Aperture Radar

Integrated Information Dissemination Division, Integrated Taxonomic Information System

Integrated Water Availability Assessments

mission areas

Methylmercury 


\begin{tabular}{|c|c|c|c|}
\hline MoD-FIS & $\begin{array}{l}\text { Modeling Dynamic Fuels with an Index System } \\
\text { model } \\
\text { Mineral Resources Program }\end{array}$ & $\begin{array}{l}\text { SAR } \\
\text { SCHISM }\end{array}$ & $\begin{array}{l}\text { synthetic aperture radar } \\
\text { Semi-implicit Cross-scale Hydroscience } \\
\text { Integrated System Model }\end{array}$ \\
\hline NASA & National Aeronautics and Space & SEEA & System of Environmental Economic Accounting \\
\hline NAWOA & $\begin{array}{l}\text { Administration } \\
\text { National Water-Quality Assessment Project }\end{array}$ & SHIRA & $\begin{array}{l}\text { Department of the Interior Strategic Hazard } \\
\text { Identification and Risk Assessment }\end{array}$ \\
\hline NAWOA-ACT & $\begin{array}{l}\text { National Water-Quality Assessment Project } \\
\text { Agricultural Chemical Transport }\end{array}$ & $\begin{array}{l}\text { SIR } \\
\text { SLR }\end{array}$ & $\begin{array}{l}\text { Scientific Investigations Report } \\
\text { sea level rise }\end{array}$ \\
\hline NCGMP & $\begin{array}{l}\text { National Cooperative Geologic Mapping } \\
\text { Program }\end{array}$ & SRTM & Shuttle Radar Topography Mission \\
\hline NED & U.S. Geological Survey National Elevation Data & SWFL & Southwestern Willow Flycatcher \\
\hline NEPA & National Environmental Policy Act & UAS & Unmanned Aircraft Systems \\
\hline NER & Northeast Region & UN & United Nations \\
\hline NGO & non-governmental organization & USDA & U.S. Department of Agriculture \\
\hline NHD & National Hydrography Dataset & USDOI & Department of the Interior \\
\hline NLCD & National Land Cover Database & USFWS & U.S. Fish and Wildlife Service \\
\hline NOAA & $\begin{array}{l}\text { National Oceanic and Atmospheric } \\
\text { Administration }\end{array}$ & $\begin{array}{l}\text { USGS } \\
\text { USNVC }\end{array}$ & $\begin{array}{l}\text { U.S. Geological Survey } \\
\text { U.S. National Vegetation Classification }\end{array}$ \\
\hline NPS & U.S. National Park Service & WAUSP & Water Availability and Use Science Program \\
\hline NRP & National Research Program & WERC & Western Ecological Research Center \\
\hline NWHC & National Wildlife Health Center & WMA & Water Resources Mission Area \\
\hline $\begin{array}{l}\text { OK-TX WSC } \\
\text { PI }\end{array}$ & $\begin{array}{l}\text { Oklahoma-Texas Water Science Center } \\
\text { Principal Investigator }\end{array}$ & WRAP/ESPD & $\begin{array}{l}\text { Water Availability and Use Science Program/ } \\
\text { Earth Systems Processes Division }\end{array}$ \\
\hline PRMS & Precipitation Runoff Modeling System & WRIR & Water-Resources Investigations Report \\
\hline ow & water quality & WSC & Water Science Center \\
\hline SAFRR & Science Application for Risk Reduction & & \\
\hline
\end{tabular}


Table 4.1. Summary of survey responses describing multidisciplinary projects.

[*Information in the table cells includes direct survey responses from individuals and have not been altered. Some abbreviations may reflect respondents understanding of commonly used abbreviations and some abbreviations are not defined. Due to the large list of abbreviations in this table, the abbreviations are listed at the beginning of this appendix.]

\begin{tabular}{|c|c|c|c|}
\hline Location & Integration disciplines & Skills & Capability \\
\hline \multicolumn{4}{|c|}{ Coastal ecosystems } \\
\hline $\begin{array}{l}\text { Baton Rouge, } \\
\text { Louisiana }\end{array}$ & Geophysics, water (coastal hydrology) & $\begin{array}{l}\text { Ecosystem modeling coupled with } \\
\text { field observation, application of } \\
\text { remote sensing, GIS, GPS, and } \\
\text { spatial statistics }\end{array}$ & Wetland Morphology Model \\
\hline \multicolumn{4}{|c|}{ Coastal hydrology } \\
\hline $\begin{array}{l}\text { Woods Hole, } \\
\text { Massachusetts }\end{array}$ & Coastal wetlands & UAS, restoration science & $\begin{array}{l}\text { How restoration structures reduce the impact of wave } \\
\text { and current energy on marsh edges in estuaries and } \\
\text { bays }\end{array}$ \\
\hline \multicolumn{4}{|c|}{ Coastal Marine } \\
\hline $\begin{array}{l}\text { Sioux Falls, } \\
\quad \text { South Dakota }\end{array}$ & Water & Elevation mapping & $\begin{array}{l}\text { Sea level rise vulnerability; seamless elevation datasets } \\
\text { (NED and SRTM) }\end{array}$ \\
\hline $\begin{array}{l}\text { Lafayette, } \\
\quad \text { Louisiana }\end{array}$ & Sediment (water) & Coproduction & $\begin{array}{l}\text { Mississippi Coastal Improvements Program } \\
\text { coproduction, barrier islands, erosion, and deposition }\end{array}$ \\
\hline
\end{tabular}

Coastal/marine (remote sensing)

\begin{tabular}{lccl} 
& & Coastal/marine (remote sensing) & \\
\hline $\begin{array}{c}\text { Woods Hole, } \\
\text { Massachusetts }\end{array}$ & Hazards, coastal sediment & Remote sensing & Coastal remote sensing
\end{tabular}

\section{Core Science data management}

\begin{tabular}{|c|c|c|c|}
\hline $\begin{array}{l}\text { Lakewood, } \\
\text { Colorado }\end{array}$ & Water, ecosystems & $\begin{array}{l}\text { Director of Science Analytics and } \\
\text { Synthesis }\end{array}$ & $\begin{array}{l}\text { Data management and access; Science data managemen } \\
\text { tools such as ScienceBase, Science Data Catalog, } \\
\text { USGS Model Catalog; Advanced Research } \\
\text { Computing (Denali, Yeti, Tallgrass, Rescale) capacity } \\
\text { and expertise supports all Programs, National Fish } \\
\text { Habitat Partnership, National Biogeographic Map, } \\
\text { ACIO Data Lake and CHS, etc. }\end{array}$ \\
\hline
\end{tabular}

\begin{tabular}{ll}
\hline $\begin{array}{l}\text { Santa Cruz, } \\
\text { California }\end{array}$ & Water, sediment, habitats
\end{tabular}

\section{California}

Scientific monitoring and analyses of the fish, waters, and sediment, before, during, and after this historic event. This work is coordinated with the Olympic National Park, Lower Elwha Klallam Tribe, the Bureau of Reclamation, Washington Department of Fish and Wildlife, U.S. Fish and Wildlife Service, the Environmental Protection Agency, the National Oceanic and Atmospheric Administration, and other local and state entities.

\begin{tabular}{|c|c|c|c|}
\hline $\begin{array}{l}\text { Woods Hole, } \\
\text { Massachusetts }\end{array}$ & Hazards, socioeconomics & $\begin{array}{l}\text { Digital Shoreline Analysis System } \\
\text { (DSAS) }\end{array}$ & $\begin{array}{l}\text { Coastal storm response. decision support, risk } \\
\text { assessment, near-term, operational, and scenario } \\
\text { forecasting; shoreline change analysis and the impact } \\
\text { of geologic processes and human activities on the } \\
\text { form and history of coastal beaches }\end{array}$ \\
\hline
\end{tabular}

Woods Hole, Water, sediment $\quad$ COAWST modeling Hydrodynamic modeling of the Delaware Bay


Coastal ecosystems

Ecosystems: Environments; Land Resources: Land Change https://www.usgs.gov/centers/wetland-and-aquatic-research-center-warc/science/collectingScience Program ecological-data-and-models?qt-science_center_objects=0\#qt-science_center_objects

\section{Coastal hydrology}

Core Science Systems: National Geospatial Program; Natural Hazards: Coastal \& Marine Hazards and Resources Program; Water Resources: Water Observing Systems Program;
I've continued to lead the North Atlantic Appalachian Region UAS capability team consisting of members from the National UAS project office in Denver, water science offices throughout New England, and the three coastal and marine offices.

\section{Coastal Marine}

Core Science Systems: National Geospatial Program; Land Resources: Land Change Science Program; Natural Hazards: Coastal \& Marine Hazards and Resources https://www.usgs.gov/centers/eros/science/sea-level-rise-vulnerability https://www.usgs.gov/core-science-systems/eros/topochange Program

Core Science Systems: National Geospatial Program; Ecosystems: Environments; Land Resources: Land Change Science Program; Natural Hazards: Coastal \& Marine Hazards and Resources Program; Water Resources: Water Resources Availability Program

Mississippi Coastal Improvements Program (MsCIP) - Adaptive Management and Monitoring Planning and Implementation: https://www.usgs.gov/centers/wetland-and-aquatic-researchcenter-warc/science/mississippi-coastal-improvements-program?qt-science_center_ objects=0\#qt-science_center_objects; Alabama Barrier Island Restoration Assessment at Dauphin Island: https://www.usgs.gov/centers/wetland-and-aquatic-research-center-warc/ science/alabama-barrier-island-restoration?qt-science_center_objects=0\#qt-science_center_ objects

Ecosystems: Fisheries; Natural Hazards: Coastal \& Marine https:/www.usgs.gov/centers/pcmsc/science/usgs-science-supporting-elwha-river-restorationHazards and Resources Program; Natural Hazards: Landslide Hazards; Water Resources: Water Observing Systems Program project?qt-science_center_objects $=0$ \#qt-science_center_objects

https://www.usgs.gov/centers/pcmsc/science/remote-sensing-coastal-change?qt-science_center_ objects $=0 \# q t-$ science_center_objects
Fort Collins Science Center (social scientist)

Natural Hazards: Coastal \& Marine Hazards and Resources Program; Water Resources: Water Observing Systems Program; Water Resources: Integrated Water Prediction Program

marine.usgs.gov/coastalchangehazardsportal (currently being migrated to a public-facing application in CHS), https://wim.usgs.gov/geonarrative/cch-ourcoasts/ initial output from work done with funding from USGS Risk COP to expand stakeholder engagement capabilities and better message our science to meet end user needs in decision support, risk assessment, near-term, operational, and scenario forecasting.

I am involved in hydrodynamic modeling of the Delaware Bay estuarine system that uses CONED USGS data products, observational output, high performance computing, all within a system that requires understanding of land-ocean interactions. I'm sure there are areas that I did not highlight above that are included in this project. (I have been working here $<1$ year, so my understanding of the USGS org chart is still growing)

Coastal/marine (remote sensing)

Natural Hazards: Coastal \& Marine Hazards and Resources Program

Remote Sensing Coastal Change project: https://www.usgs.gov/centers/pcmsc/science/remotesensing-coastal-change?qt-science_center_objects $=0 \#$ qt-science_center_objects Florence Disaster Relief Funding project

Core Science data management

Core Science Systems: National Geologic and Geophysical Data Preservation Program; Core Science Systems: National Geospatial Program; Core Science Systems: Science Analytics and Synthesis (SAS); Ecosystems: Fisheries; Ecosystems: Invasive Species; Ecosystems: Status \& Trends; Land Resources: Land Change Science Program; Natural Hazards: Earthquake Hazards; Natural Hazards: Landslide Hazards; Water Resources: Water Observing Systems Program
Science data management tools such as ScienceBase, Science Data Catalog, USGS Model Catalog; Advanced Research Computing (Denali, Yeti, Tallgrass, Rescale) capacity and expertise supports all Programs, National Fish Habitat Partnership, National Biogeographic Map, ACIO Data Lake and CHS, etc. 
Table 4.1. Summary of survey responses describing multidisciplinary projects.—Continued

[*Information in the table cells includes direct survey responses from individuals and have not been altered. Some abbreviations may reflect respondents understanding of commonly used abbreviations and some abbreviations are not defined. Due to the large list of abbreviations in this table, the abbreviations are listed at the beginning of this appendix.]

\begin{tabular}{clcl}
\hline \multicolumn{1}{c}{ Location } & Integration disciplines & \multicolumn{1}{c}{ Skills } & Capability \\
\hline $\begin{array}{c}\text { Cook, } \\
\text { Washington }\end{array}$ & Wildlife & Data management & \\
\hline $\begin{array}{c}\text { Catonsville, } \\
\text { Maryland }\end{array}$ & Websites, communication & $\begin{array}{c}\text { Developing APIs to support } \\
\text { enterprise level monitoring } \\
\text { using existing tools }\end{array}$ & $\begin{array}{c}\text { Four large-scale, long-term natural resource monitoring } \\
\text { programs; data accessibility tools; Coordinating } \\
\text { standards and methods for data }\end{array}$ \\
\hline $\begin{array}{c}\text { Woods Hole, } \\
\text { Massachusetts }\end{array}$ & Communication, coastal/marine & Web development & Communication, websites, data management \\
& & Ocean Data Ambassador & $\begin{array}{l}\text { USGS Ocean Data Ambassador; data preservation } \\
\text { data management } \\
\text { data communication } \\
\text { knowledge information system development } \\
\text { improvement of scientific data usability }\end{array}$
\end{tabular}

\begin{tabular}{clcc}
\hline $\begin{array}{c}\text { Lawrence, } \\
\text { Kansas }\end{array}$ & Water & IT & Data management \\
\hline $\begin{array}{c}\text { Middleton, } \\
\text { Wisconsin }\end{array}$ & Water, ecosystems (fisheries) & $\begin{array}{c}\text { Model calibration and inference } \\
\text { of environmental systems }\end{array}$ & $\begin{array}{c}\text { Decision-making support for environmental managers } \\
\text { that considers uncertainty in all aspects of decisions } \\
\text { and strives to extract the most information from the } \\
\text { data }\end{array}$ \\
& &
\end{tabular}

\section{Ecosystems}

Jamestown, Water, wildlife, habitat, climate PHyLiSS model; trend

North Dakota

PHyLiSS model; trends

Missouri Coteau Wetlands; Prairie pothole climate/ habitat; waterfowl; climate and land-use change on critical migratory waterfowl habitat. Pothole Hydrology Linked Systems Simulator (PHyLiSS), which is an integrated hydro-geochemical model for prairie pothole wetlands.

\begin{tabular}{cc}
\hline $\begin{array}{c}\text { West Glacier, } \\
\text { Montana }\end{array}$ & Andscapes, Wildlife, Water, Citizen tools, Communications \\
Science &
\end{tabular}

Citizen science software; (1) understand the influence of humans and associated land use impacts on wildlife distributions, densities, and related processes at local and landscape scales, (2) develop new analytical tools that address the influence of landscape features on animals at the sub-population and population scales, and (3) improve efficiency of research and monitoring

Science analysis and synthesis (SAS)

\begin{tabular}{cccc}
\hline $\begin{array}{l}\text { Fort Collins } \\
\text { Colorado }\end{array}$ & Water Quality, Landscapes, Hydrology, & Ecosystem modeling, synthesis & western mountains
\end{tabular}

Coastwide reference monitoring system; landcarbon program; how ecosystem functions, such as elevation change, carbon cycling, and resilience, are affected by global stressors

St Petersburg, Water, climate, pathogens Metagenomics
Florida
Coral reefs, habitat, climate; determine if the spread of coral disease is affected by the level of connectivity among water masses, organisms, trophic levels, or habitats 


\section{Data management}

Core Science Systems: Science Analytics and Synthesis (SAS); Ecosystems: Environments; Ecosystems: Fisheries

Water Resource Variables at Water Science Center (MD. DE.DC)

Water Resources, some of the former subdivisions; Core Science Systems: National Cooperative Geologic Mapping Program; Core Science Systems: National Geologic and Geophysical Data Preservation Program; Core Science Systems: National Geospatial Program; Core Science Systems: Science Analytics and Synthesis (SAS); Ecosystems: Fisheries; Energy and Minerals: Mineral Resources; Energy and Minerals: Energy Resources; Land Resources: National Land Imaging Program; Natural Hazards: Coastal \& Marine Hazards and Resources Program; Natural Hazards: Earthquake Hazards

Mostly admin database https://www.pnamp.org/project/habitat-metric-data-integration, https://www. monitoringresources.org/, https://pubs.er.usgs.gov/publication/fs20183015,

Evolving sites:

https://www.usgs.gov/centers/md-de-dc-water https://www.usgs.gov/

Much of this work has be done through the Community for Data Integration (CDI)

\section{Decision science}

Ecosystems: Invasive Species; Water Resources: Water Resources Availability Program; Water Resources: Water Observing Systems Program; Water Resources: Integrated Water Prediction Program; Water Resources: Water Resources Research Act Program
AIS
Most of my cross-mission-area collaboration has focused on workflows and high-throughput computing. groundwater quantity and quality; statistical inference and prediction of recreational water quality on beaches; mercury in water and fish; and the groundwater and habitat impacts of sea-level rise. In support of these threads, aspects of computational efficiency, statistical analysis, and data management

\section{Ecosystems}

North Central \& Midwest Climate Adaptation Science Center; Ecosystems: Status \& Trends; Energy and Minerals: Science \& Decisions Center; Land Resources: Land Change Science Program; Water Resources: Water Resources Research Act Program

Member of MUSCLE; Ecosystems: Status \& Trends; Ecosystems: Wildlife Disease; Water Resources: Water Observing Systems Program; Water Resources: Integrated Water Prediction Program https://wim.usgs.gov/geonarrative/mcweo/

https://cascprojects.org/\#/project/4f83509de4b0e84f60868124/5b33be6fe4b040769c172fad https://cascprojects.org/\#/project/5050cb0ee4b0be20bb30eac0/5f29c43982cef313ed9edb1d

Previously worked with FORT computer scientists to develop citizen science appScienceCache. We have moved on from this effort, so no current links.
Core Science Systems: Science Analytics and Synthesis (SAS); Ecosystems: Wildlife Disease

Core Science Systems: Science Analytics and Synthesis (SAS); Ecosystems: Environments; Land Resources: Land Change Science Program

Ecosystems: Environments; Land Resources: Land Change Science Program; Water Resources: Water Resources Availability Program

Ecosystems: Energy and Wildlife; Ecosystems Environments; Ecosystems: Fish \& Wildlife Disease; Ecosystems: Wildlife Disease; Natural Hazards: Coasta \& Marine Hazards and Resources Program
As a Center manager I supported SAS-EMA collaboration on Avian Influenza transmission modeling; this is probably the closest thing to the multiple mission area collaboration that matches some of the vision of EarthMAP. https://www.pwrc.usgs.gov/ai/

https://www.usgs.gov/centers/powell-ctr

https://www.usgs.gov/centers/fort/science/western-mountain-initiative-wmi?qt-science_center_ objects $=0 \# q t-$ science_center_objects

http://lacoast.gov/crms/

https://www.usgs.gov/ecosystems/land-change-science-program/science/landcarbon?qt-science center_objects $=0 \#$ qt-science_center_objects

https://www.usgs.gov/centers/wetland-and-aquatic-research-center-warc/science/discovrediversity-systematics-and?qt-science_center_objects=0\#qt-science_center_objects

https://www.usgs.gov/centers/spcmsc/science/microbial-processes-reefs?qt-science_center_ objects $=0 \# q t-$ science_center_objects 
Table 4.1. Summary of survey responses describing multidisciplinary projects.-Continued

[*Information in the table cells includes direct survey responses from individuals and have not been altered. Some abbreviations may reflect respondents understanding of commonly used abbreviations and some abbreviations are not defined. Due to the large list of abbreviations in this table, the abbreviations are listed at the beginning of this appendix.]

\begin{tabular}{|c|c|c|c|}
\hline Location & Integration disciplines & Skills & Capability \\
\hline $\begin{array}{l}\text { Lafayette } \\
\quad \text { Louisiana }\end{array}$ & Water, carbon, climate & FLUXNET modeling & $\begin{array}{l}\text { Louisiana coastal habitats; wetland ecosystem } \\
\text { transitions; Great Plains landcarbon; inks between } \\
\text { empirical studies and modeling in physiological and } \\
\text { ecosystem ecology } 3 / 13 / 202 \text {; USGS LandCarbon } \\
\text { National Assessment and the Powell Center Wetland } \\
\text { FLUXNET Synthesis for Methane }\end{array}$ \\
\hline $\begin{array}{l}\text { Moffett Field, } \\
\text { California }\end{array}$ & Coastal, wildlife (birds) & Remote sensing, decision support & $\begin{array}{l}\text { Landscape Ecology, Remote Sensing, and Decision } \\
\text { Support; Coastal wetland blue carbon, eco } \\
\text { forecasting, rangeland ecosystem services; Nisqually } \\
\text { River Delta, Washington State, restoration efforts } \\
\text { aimed at converting diked farmland back to tidal } \\
\text { marsh. California's Central Valley croplands and } \\
\text { wetlands; a region required for the wide-ranging } \\
\text { ecology of migratory waterbirds; Integrating the } \\
\text { water and wetland habitat forecast models with } \\
\text { species and ecosystem services }\end{array}$ \\
\hline $\begin{array}{l}\text { Cook, } \\
\text { Washington }\end{array}$ & $\begin{array}{l}\text { Pacific Northwest Aquatic Monitoring } \\
\text { Partnership (PNAMP) }\end{array}$ & $\begin{array}{l}\text { Data compilation and access; } \\
\text { water, habitat; }\end{array}$ & $\begin{array}{l}\text { The Large River Monitoring Forum focuses on fish, } \\
\text { fish habitat research, and monitoring approaches, } \\
\text { including scientific objectives for comparisons within } \\
\text { and among aquatic ecosystems; scientifically sound } \\
\text { monitoring design; methods for data collection and } \\
\text { analysis; and best practices for data and information } \\
\text { management. This forum enhances agency capacity } \\
\text { by sustaining collaboration among USGS expert } \\
\text { staff as well as provide opportunity for collaborating } \\
\text { agencies and tribes to contribute to the development } \\
\text { of recommendations for the implementation of a } \\
\text { national network. }\end{array}$ \\
\hline
\end{tabular}

Ecosystems (aquatic habitat)

\begin{tabular}{|c|c|}
\hline Kearneysville, & Water, landscapes \\
\hline
\end{tabular}

\section{Ecosystems (birds)}

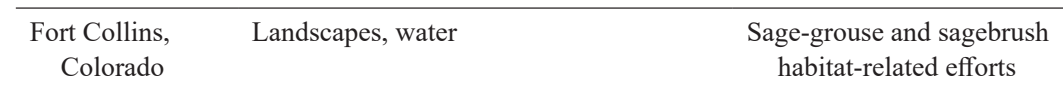

Wyoming Landscape Conservation Initiative (WLCI); biologists, hydrologists, geologists, soil scientists and Core science specialists

\begin{tabular}{|c|c|c|c|}
\hline \multicolumn{4}{|c|}{ Ecosystems (Fisheries) } \\
\hline $\begin{array}{l}\text { Ashland, } \\
\text { Wisconsin }\end{array}$ & Lake hydrology & $\begin{array}{l}\text { Acoustic estimating of fish } \\
\text { density and biomass }\end{array}$ & $\begin{array}{l}\text { Lake-wide density and biomass of all biota in Lake } \\
\text { Superior; acoustic estimation of pelagic prey fish } \\
\text { density and biomass; habitat, biodiversity, }\end{array}$ \\
\hline
\end{tabular}


USGS Collaboration

Ecosystems: Environments; Land Resources: Land Change Science Program
Relevant projects

https:/www.usgs.gov/centers/wetland-and-aquatic-research-center-warc/science/critical-coastalhabitats-sustainability

https:/www.usgs.gov/ecosystems/land-change-science-program/science/impacts-coastal-andwatershed-changes-upper-estuaries

https://www.usgs.gov/ecosystems/land-change-science-program/science/landcarbon
Water Science Centers; Core Science Systems: National Geospatial Program; Ecosystems: Energy and Wildlife; Ecosystems: Environments; Ecosystems: Fisheries; Ecosystems: Status \& Trends; Energy and Minerals: Science \& Decisions Center; Land Resources: Land Change Science Program; Land Resources: National Land Imaging Program; Natural Hazards: Coastal \& Marine Hazards and Resources Program; Water Resources: Water Resources Availability Program;
See:

https://www.usgs.gov/staff-profiles/kristin-byrd?qt-staff_profile_science_products=0\#qt-staff_ profile_science products

https://www.usgs.gov/centers/wgsc/science/applied-landscape-ecology-and-remote-sensing?qtscience_center_objects $=0 \# q$ t-science_center_objects

https://www.usgs.gov/centers/wgsc/science/ecosystem-services-assessment-nisqually-riverdelta-south-puget-sound?qt-science_center_objects=0\#qt-science_center_objects

http://climate.calcommons.org/forecasting-central-valley-water

I facilitate the Large River Monitoring Forum, which engages colleagues from multiple USGS Centers and outside the USGS: https:/www.sciencebase.gov/catalog/ item/56f0319ce4b0f59b85dd1238

(SAS); Ecosystems: Environments; Ecosystems: Fisheries; Ecosystems: Invasive Species; Ecosystems: Status \& Trends; Land Resources: Land Change Science Program; Water Resources: Water Observing Systems Program; Water Resources: Water Resources Research Act Program
I manage a project working to publish integrated datasets from multiple partner agencies, which is funded in part by CSS SAS: https://pnamp.org/project/habitat-metric-data-integration

Ecosystems (aquatic habitat)

Ecosystems: Energy and Wildlife; Ecosystems: Environments; Ecosystems: Fish \& Wildlife Disease; Ecosystems: Fisheries
(1) We are linking Ecosystems and Core Science Systems research via https://www.usgs.gov/ centers/lsc/science/enabling-ai-citizen-science-fish-biology

(2) We are linking Ecosystems and Water Mission Area research as described in https://pubs. er.usgs.gov/publication/cir1430

Ecosystems (birds)

Ecosystems: Environments; Ecosystems: Status \& Trends; Land Resources: Land Change Science Program; Water Resources: Water Resources Research Act Program soil scientists and Core science specialists. I also worked for several years with the Great
I have worked with the Wyoming Landscape Conservation Initiative (WLCI) for 10 years - our USGS science team is multidisciplinary and has included biologists, hydrologists, geologists, Plains Landscape Conservation Cooperative which included work with Land change and water resources scientists.

Ecosystems (Fisheries)

Ecosystems: Environments; Ecosystems: Fisheries; Ecosystems: Invasive Species; Ecosystems: Status \& Trends
Every five years I work on a multi-agency team that estimates lake-wide density and biomass of all biota in Lake Superior from phytoplankton to piscivorous fish using a depth-stratified and spatially-balanced design having 56 sites. The work is funded through the Coordinated Science Monitoring Initiative of the Great Lakes Restoration Initiative Act. Lake Superior represents about $1 \%$ of the area of the continental US so it an important resource on the landscape for sure. My specific role is acoustic estimation of pelagic prey fish density and biomass which gets published through data releases. As an example, see https://www. sciencebase.gov/catalog/item/5f43d7c682ce $4 \mathrm{c} 3 \mathrm{~d} 1222 \mathrm{~d} 328$. We're currently working to build an ecosystem model that uses these data (and other agency) data to forecast the trajectory of ecosystem component. We want to begin to more reliably predict how the ecosystem may respond to environmental drivers and how fish community objectives may respond to management alternatives. It has been a bit of a tough slog because we're in the rust belt and have fewer researchers than the other Great Lakes, but we're making progress. 
Table 4.1. Summary of survey responses describing multidisciplinary projects.-Continued

[*Information in the table cells includes direct survey responses from individuals and have not been altered. Some abbreviations may reflect respondents understanding of commonly used abbreviations and some abbreviations are not defined. Due to the large list of abbreviations in this table, the abbreviations are listed at the beginning of this appendix.]

\begin{tabular}{|c|c|c|c|}
\hline Location & Integration disciplines & Skills & Capability \\
\hline $\begin{array}{l}\text { Columbia, } \\
\text { Missouri }\end{array}$ & Water & Sturgeon research & $\begin{array}{l}\text { The USGS Comprehensive Sturgeon Research Project } \\
\text { is a multi-year, interdisciplinary research study to } \\
\text { determine factors leading to spawning and survival of } \\
\text { the endangered pallid sturgeon and the closely related } \\
\text { shovelnose sturgeon. }\end{array}$ \\
\hline $\begin{array}{l}\text { Gainesville, } \\
\text { Florida }\end{array}$ & Water, aquatic habitat & Faunal surveys & $\begin{array}{l}\text { Faunal surveys, distributional analyses, species biology, } \\
\text { experimental field and laboratory ecology, limiting } \\
\text { factors, and behavior of rare, threatened, and } \\
\text { endangered freshwater fishes of the southeastern } \\
\text { United States. }\end{array}$ \\
\hline $\begin{array}{l}\text { Jackson, } \\
\text { Wyoming }\end{array}$ & Water, energy, contamination & $\begin{array}{l}\text { Multi-resource assessment } \\
\text { methods }\end{array}$ & $\begin{array}{l}\text { Multi-resource assessment methods; effects of oil } \\
\text { and gas activities on aquatic life; Restoration } \\
\text { of Contaminated and Impaired Ecosystems; } \\
\text { Fish physiology to complement toxicological } \\
\text { investigations }\end{array}$ \\
\hline
\end{tabular}

\section{Ecosystems (flora)}

\begin{tabular}{ll}
\hline Jackson, & Landscapes detection of invasives \\
Wyoming &
\end{tabular}

Wyoming landscape initiative; climate and land-use change on ecological processes such as fire regimes and plant productivity; testing methods to restore pinyon-juniper woodlands with native grass species in New Mexico to designing methods to quantify plant diversity and detect rare native and non-native (early detection) plant species.

\begin{tabular}{|c|c|c|}
\hline $\begin{array}{l}\text { La Crosse, } \\
\text { Wisconsin }\end{array}$ & Landscapes, remote sensing, water & $\begin{array}{l}\text { Document vegetation in the } \\
\text { field and interpret aerial } \\
\text { imagery to the finest scale of } \\
\text { the U.S. National Vegetation } \\
\text { Classification (USNVC) for } \\
\text { vegetation mapping projects }\end{array}$ \\
\hline $\begin{array}{l}\text { Henderson, } \\
\text { Nevada }\end{array}$ & $\begin{array}{l}\text { Landscapes, energy development, fire } \\
\text { ecology, climate }\end{array}$ & Mapping plant ecology \\
\hline
\end{tabular}

Predicting invasive species mapping model (INHABIT)
Classifies, describes, and maps existing vegetation of national park units for the NPS Natural Resource Inventory and Monitoring (I\&M) Program; Jean Lafitte National Historical Park; Appalachian trail

Southwest Energy Development and Drought (SWEDD): understand how past and current energy development are impacting the social-ecological systems of the Colorado Plateau, and to identify strategies to mitigate deleterious consequences of these activates now and into the future

Predicting invasive species mapping model (INHABIT); patterns of seed production and regeneration in forests; MASTREEPLUS; plant-insect interactions and community ecology

\section{Ecosystems (forests)}

\begin{tabular}{cc}
\hline Lafayette, & Remote sensing, flora mapping, sediment, Image processing \\
Louisiana & climate
\end{tabular}

Lafayette,
Louisiana
climate

Ecosystems (geography) 
USGS Collaboration

Ecosystems: Fisheries; Ecosystems: Invasive Species; Environmental Health: Contaminant Biology;
Relevant projects

https://www.usgs.gov/CSRP_Blog

Core Science Systems: Science Analytics and Synthesis

https://itis.gov/

(SAS); Ecosystems: Fisheries; Ecosystems: Invasive Species

As part of the EH Program IST, currently planning a workshop with Ecosystems and Water; and also hope to include Energy and Minerals to develop guidelines for conducting Multi-Resource Assessments for use by client agencies
The workshop described above is in beginning stages, no website, etc. is available.

\section{Ecosystems (flora)}

Fire, energy development, salinity (Colorado River); Ecosystems: Energy and Wildlife; Ecosystems: Environments; Ecosystems: Fish \& Wildlife Disease; Ecosystems: Invasive Species; Ecosystems: Status \& Trends; Ecosystems: Wildlife Disease; Land Resources: Land Change Science Program

Wyoming Landscape Conservation Initiative:

https://www.usgs.gov/centers/fort/science/wyoming-landscape-conservation-initiative-wlci?qtscience_center_objects $=0 \#$ qt-science_center_objects

Ecosystems: Environments

My group has created science and management quality maps and information products for close to 20 National Parks and many USFWS refuges. The NPS data is all served via the IRMA website. Here are, as examples, the links to the Appalachian National Scenic Trail and Jean Lafitte National Historical Park and Preserve:

https://irma.nps.gov/DataStore/Reference/Profile/2240273

https://irma.nps.gov/DataStore/Reference/Profile/2247523

Ecosystems: Environments; Ecosystems: Invasive Species; https://www.usgs.gov/centers/sbsc/science/southwest-energy-development-and-droughtEcosystems: Status \& Trends; Land Resources: Land Change Science Program swedd?qt-science center_objects $=0 \# q t$-science center_objects

Core Science Systems: National Geospatial Program; Ecosystems: Invasive Species; Ecosystems: Status and Trends
I am involved in large-scale predictive mapping of invasive species (i.e. the INHABIT tool https://gis.usgs.gov/inhabit/sandbox.rmd) and modeling their impacts and control strategies. I work on large-scale patterns of seed production and regeneration in forests, where I am actively compiling nationwide and international information on seed production of individual tree species (e.g. https://mastreeplus.shinyapps.io/mastreeplus/). Most of these projects are collaborations with a wide range of agencies (primarily USDOI, USDA, and NASA) and non-federal stakeholders and provide maps and other predictive tools that are used in addressing important challenges. I would be interested in integrating these capacities within the EarthMap framework.

Ecosystems (forests)

Hazards-flooding, oil spill exposure, wind damage, forestmarsh dieback onset and progression; Ecosystems: Environments; Ecosystems: Invasive Species; Ecosystems: Status \& Trends
Mapping storm damage, flooding, oil exposure, SAR-optical fusion for enhanced and dynamic status and trends and emergency response

\section{Ecosystems (geography)}

Land Resources: Land Change Science Program; Land Resources: National Land Imaging Program
I am involved in many multi-agency and international/intergovernmental collaborations, much more than internal collaborations 
Table 4.1. Summary of survey responses describing multidisciplinary projects.-Continued

[*Information in the table cells includes direct survey responses from individuals and have not been altered. Some abbreviations may reflect respondents understanding of commonly used abbreviations and some abbreviations are not defined. Due to the large list of abbreviations in this table, the abbreviations are listed at the beginning of this appendix.]

\begin{tabular}{llcl}
\hline \multicolumn{1}{c}{ Location } & Integration disciplines & Skills & Capability \\
\hline $\begin{array}{c}\text { Fort Collins, } \\
\text { Colorado }\end{array}$ & Climate, landscapes, fire & Ecosystems (grasslands) & \\
& & Streamlining the NEPA process & $\begin{array}{c}\text { Grasslands, climate change, BLM Rapid Assessment; } \\
\text { Wyoming Basin rapid assessment; S Plains rapid } \\
\text { ecoregional assessment; landscape, community, and } \\
\text { fire ecology to multiscale land management issues; } \\
\text { approaches for conducting broad-scale assessments } \\
\text { and streamlining the NEPA process }\end{array}$ \\
\hline Reston, Virginia & & \\
\hline
\end{tabular}

\begin{tabular}{|c|c|c|c|}
\hline \multicolumn{4}{|c|}{ Ecosystems (landscapes) } \\
\hline Boise, Idaho & Water, soil, decision science & Restoration management tool & $\begin{array}{l}\text { Land treatment exploration tool; Integrating short- } \\
\text { term climate forecast into a restoration management } \\
\text { support tool }\end{array}$ \\
\hline $\begin{array}{l}\text { Los Alamos, } \\
\text { New Mexico, } \\
\text { The New } \\
\text { Mexico } \\
\text { Landscapes } \\
\text { Field Station }\end{array}$ & Hydrology, denrochronology & Systems science & $\begin{array}{l}\text { Place-based, globally connected, ecological research on } \\
\text { ecosystem and wildlife dynamics, working with land } \\
\text { managers and community leader; short- and long- } \\
\text { term interactions between ecosystem and hydrologic } \\
\text { processes, climate variability, and disturbance; } \\
\text { Western Mountain Initiative (WMI) is a long-term } \\
\text { collaboration to address changes in montane forests } \\
\text { and watersheds due to climate change. Landscape } \\
\text { responses to climate and disturbances (fire, drought, } \\
\text { insects) such as vegetation and erosion changes, } \\
\text { piñon-juniper demography and mortality, weekly } \\
\text { tree growth, ground-dwelling arthropod population } \\
\text { fluctuations, and detailed ecohydrological info. } \\
\text { Forest Dieback: reconstruction of historic forest } \\
\text { dieback patterns; monitoring of forest and woodland } \\
\text { demographies (tree mortality and regeneration); } \\
\text { experimental determination of physiological } \\
\text { thresholds of drought- and heat-induced tree } \\
\text { mortality; relationships between tree growth, drought } \\
\text { stress, insects/diseases, and mortality; remote-sensing } \\
\text { of landscape-scale patterns of forest stress and die- } \\
\text { off; documentation of regional, national, and global } \\
\text { patterns of forest die-off; and efforts to improve } \\
\text { models of tree mortality processes. }\end{array}$ \\
\hline
\end{tabular}


Ecosystems (grasslands)

Ecosystems: Energy and Wildlife; Ecosystems: Environments; Ecosystems: Fish \& Wildlife Disease https://pubs.usgs.gov/of/2019/1046/ofr20191046.pdf

https://my.usgs.gov/wybrea/

https://pubs.er.usgs.gov/publication/ofr20151155

https://pubs.er.usgs.gov/publication/ofr20171100

https://pubs.usgs.gov/of/2018/1109/ofr20181109.pdf

\section{Ecosystems (Invasive species)}

Water Resources: National Research Program; Core Science Systems: Library; Core Science Systems: Science Analytics and Synthesis (SAS); Ecosystems: Fish \& Wildlife Disease; Ecosystems: Fisheries;

Ecosystems: Invasive Species; Ecosystems: Status \& Trends; Ecosystems: Wildlife Disease; Natural Hazards: Coastal \& Marine Hazards and Resources Program; Water Resources: Water Observing Systems Program
Ecosystems: Fire Science. Land Resources: Climate Research and Development Program (now in Ecosystems); Ecosystems: Energy and Wildlife; Ecosystems: Environments; Ecosystems: Invasive Species; Ecosystems: Status and Trends; Land Resources: Land Change Science Program; Land Resources: National Land Imaging Program; Natural Hazards: Landslide Hazards; Water Resources: Water Observing Systems Program
Ecosystems (landscapes)

https://bison.usgs.gov, https://itis.gov, https://doi.org/10.5066/P9E5K160, https://doi. org/10.5066/P9CNVBYR, https://usgs.libguides.com/edrrinvasive

https://www.usgs.gov/centers/fresc/science/land-treatment-exploration-tool https://www.usgs.gov/centers/fort/science/new-mexico-landscapes-field-station https://www.usgs.gov/ecosystems/climate-research-and-development-program/science/effectsdisturbance-and-drought-forests

https://www.usgs.gov/centers/fort/science/western-mountain-initiative-wmi https://www.usgs.gov/centers/fort/science/long-term-vital-signs-monitoring https://www.usgs.gov/centers/fort/science/tree-mortality 
Table 4.1. Summary of survey responses describing multidisciplinary projects.-Continued

[*Information in the table cells includes direct survey responses from individuals and have not been altered. Some abbreviations may reflect respondents understanding of commonly used abbreviations and some abbreviations are not defined. Due to the large list of abbreviations in this table, the abbreviations are listed at the beginning of this appendix.]

\begin{tabular}{|c|c|c|c|}
\hline Location & Integration disciplines & Skills & Capability \\
\hline \multicolumn{4}{|c|}{ Ecosystems (Soil microbiology) } \\
\hline $\begin{array}{l}\text { Menlo Park, } \\
\text { California }\end{array}$ & Water, geology & Microbiology & $\begin{array}{l}\text { Soil microbiology; microbial, chemical, and biophysical } \\
\text { controls on carbon cycling in permafrost, boreal, and } \\
\text { wetland ecosystems of Alaska as well as forest and } \\
\text { grassland ecosystems of the Western United States. }\end{array}$ \\
\hline
\end{tabular}

\section{Ecosystems (soils)}

\begin{tabular}{ccc}
\hline Moab, Utah Water (sediment, erosion) & $\begin{array}{l}\text { New methods to improve soil } \\
\text { surveys using remote sensing } \\
\text { and spatial modeling }\end{array}$ & $\begin{array}{l}\text { Salinity Yield Modeling of the Upper Colorado River } \\
\text { Basin Using 30-meter Resolution Soil Maps and } \\
\text { Random Forests; Predictive soil maps and machine } \\
\text { learning:monitoring aeolian sediment movement, } \\
\text { atmospheric dust concentrations, and related erosion } \\
\text { and dust properties }\end{array}$ \\
\hline
\end{tabular}

\begin{tabular}{|c|c|c|c|}
\hline $\begin{array}{l}\text { Denver, } \\
\quad \text { Colorado }\end{array}$ & Water, ecosystems & $\begin{array}{l}\text { Hydraulic fracturing, produced } \\
\text { waters, habitat impacts }\end{array}$ & $\begin{array}{l}\text { Impacts of oil and gas development, applied to water } \\
\text { and ecology }\end{array}$ \\
\hline
\end{tabular}

\begin{tabular}{|c|c|c|c|}
\hline $\begin{array}{l}\text { Moffett Field, } \\
\text { California }\end{array}$ & Geology, hydrology, geothermal & Multi-scale data integration & Nuclear geology at Yucca Mountain \\
\hline
\end{tabular}

Fort Worth, $\quad$ Water, hazards, geology $\quad$ Mining hazard assessment too
Texas

Conceptual Framework and Approach for Conducting a Geoenvironmental Assessment of Undiscovered Uranium Resources; (1) a descriptive geoenvironmental model; (2) maps and statistics of variables that indicate the potential for constituents of concern to occur and persist in air, land, surface water, and groundwater within a tract that is geologically permissive for the occurrence of uranium; and (3) tables providing estimated or indicated quantities of waste rock, tailings, wastewater, dust, and radon emissions that could be associated with undiscovered uranium resources, if extracted, for each permissive tract.

\begin{tabular}{|c|c|c|}
\hline \multicolumn{3}{|c|}{ Energy/Minerals } \\
\hline $\begin{array}{l}\text { Spokane, } \\
\text { Washington }\end{array}$ & $\begin{array}{l}\text { Geochronology, geochemistry, } \\
\text { and structural geology }\end{array}$ & $\begin{array}{l}\text { Trace Metal Mobility in the Yellow Pine Mining } \\
\text { District, Idaho (Antimony) }\end{array}$ \\
\hline
\end{tabular}


Core Science Systems: National Geospatial Program; Ecosystems: Energy and Wildlife; Ecosystems: Environments; Ecosystems: Fish and Wildlife Disease; Ecosystems: Status \& Trends; Energy and Minerals: Mineral Resources; Energy and Minerals: Energy Resources; Energy and Minerals: Science \& Decisions Center; Environmental Health: Contaminant Biology; Environmental Health: Toxic Substances Hydrology; Land Resources: Land Change Science Program; Land Resources: National Land Imaging Program; Natural Hazards: Landslide Hazards; Water Resources: Water Resources Availability Program; Water Resources: Water Observing Systems Program; Water Resources: Integrated Water Prediction Program; Water Resources: Water Resources Research Act Program

\section{Ecosystems (Soil microbiology)}

I have little ability to know what programs (and especially sub-programs) my colleagues work within, sometimes its multiple programs that fund something or someone, so my answers above are only guesses. Scientists often do not need this kind of information of other scientists - which is informative of what is important to scientists. They focus on the question and who has expertise rather than the funding structure. It does become obvious who cannot easily collaborate: Water has recently not allowed their researchers to work with others outside the program unless it is mandated or permitted from above.
Ecosystems (soils)

Ecosystems: Energy and Wildlife; Ecosystems: Invasive Species; Ecosystems: Status \& Trends; Water Resources: Water Resources Availability Program
https://agupubs.onlinelibrary.wiley.com/doi/full/10.1029/2018WR024054?af=R

https://www.usgs.gov/centers/sbsc/science/wind-erosion-and-dust-emissions-coloradoplateau?qt-science_center_objects $=0 \#$ qt-science_center_objects

https://www.usgs.gov/centers/sbsc/science/southwest-energy-development-and-drought-swedd

\section{Energy}

Ecosystems: Energy and Wildlife; Energy and Minerals: Mineral Resources; Energy and Minerals: Energy Resources; Energy and Minerals: Science \& Decisions Center; Land Resources: Land Change Science Program; Water Resources: Water Resources Availability Program

Core Science Systems: National Cooperative Geologic Mapping Program; Energy and Minerals: Energy Resources; Water Resources: Water Resources Availability Program

EPA projects have led to collaborations between different disciplines in the past; Environmental Health: Toxic Substances Hydrology
Part of my research focuses on quantifying the impacts of oil and gas development, applied to water and ecological stuff mainly.

Worked as a USGS geologist for 18 years on the DOE Yucca Mountain Project for nuclear waste by collecting and integrating geologic, hydrogeologic, and thermal-mechanical properties at the millimeter (thin section), decimeter to kilometer (borehole and tunnel), and multikilometer (mountain) scales.

The OK-TX WSC has worked together with Environmental Health and USGS Energy in regards to potential uranium development within the Texas Gulf Plain for the past 4 years and project is near completion. This project is a basic prototype to be used as a tool for other areas of mining activities and the potential impacts on the environment. There are several reports in review at this point as well as data releases already completed. The main report is being produced by Energy. https://pubs.er.usgs.gov/publication/sir20185104 
Table 4.1. Summary of survey responses describing multidisciplinary projects.-Continued

[*Information in the table cells includes direct survey responses from individuals and have not been altered. Some abbreviations may reflect respondents understanding of commonly used abbreviations and some abbreviations are not defined. Due to the large list of abbreviations in this table, the abbreviations are listed at the beginning of this appendix.]

\begin{tabular}{|c|c|c|c|}
\hline Location & Integration disciplines & Skills & Capability \\
\hline \multicolumn{4}{|c|}{ Fire science } \\
\hline $\begin{array}{l}\text { Cape May, New } \\
\text { Jersey }\end{array}$ & Landscapes, fire modeling & $\begin{array}{l}\text { Mapping } 30 \mathrm{M} \text { vegetation, } \\
\text { disturbance, fuels; Mod- } \\
\text { FIS model for wildfire and } \\
\text { herbaceaus veg }\end{array}$ & $\begin{array}{l}\text { Vegetation, disturbance, and fuels mapping at } 30 \mathrm{~m} \text {; } \\
\text { extensive training datasets for vegetation and } \\
\text { disturbance as well as } 29 \text { CONUS, AK and IA } \\
\text { layers of vegetation, fuels, disturbance and fire } \\
\text { regime spatial layers; annual herbaceous cover in } \\
\text { the West: Mod-FIS product depicts cheatgrass and } \\
\text { other invasives. Mod-FIS product for the great basin } \\
\text { adjusts fuel models seasonally to model wildfire } \\
\text { scenarios with current fuels data }\end{array}$ \\
\hline
\end{tabular}

\begin{tabular}{|c|c|c|c|}
\hline \multicolumn{4}{|c|}{ Geography } \\
\hline $\begin{array}{l}\text { Sioux Falls, } \\
\text { South Dakota }\end{array}$ & Landscapes, land use & NLCD program lead & Land Cover, integrated science, remote sensing \\
\hline Reston, Virginia & Landscape ecology & $\begin{array}{l}\text { National Map (TNM) Delivery } \\
\text { Services }\end{array}$ & $\begin{array}{l}\text { Topographic maps and geographic information system } \\
\text { (GIS) data for elevation, hydrography, watersheds, } \\
\text { geographic names, orthoimagery, governmental } \\
\text { units/boundaries, transportation, and land cover; } \\
\text { nationwide lidar (IfSAR in AK) by } 2023 \text { to provide } \\
\text { the first-ever national baseline of consistent high- } \\
\text { resolution topographic elevation data; The USGS } \\
\text { National Geospatial Program manages the National } \\
\text { Hydrography Dataset (NHD), Watershed Boundary } \\
\text { Dataset (WBD), and NHDPlus High Resolution } \\
\text { (NHDPlus HR). }\end{array}$ \\
\hline
\end{tabular}

\begin{tabular}{|c|c|c|c|}
\hline & & Geolos & \\
\hline $\begin{array}{c}\text { Moffett Field, } \\
\text { California }\end{array}$ & Hazards, coastal/marine & Communication & Tsunamis, landslides, SLR \\
\hline
\end{tabular}

Indianapolis, GW mapping
Indiana

$\begin{array}{lll}\text { Indianapolis, } & \text { Groundwater } & \text { GW mapping }\end{array}$

\begin{tabular}{lcc}
\hline $\begin{array}{l}\text { Denver, } \\
\text { Colorado }\end{array}$ & Water, dust hazards & $\begin{array}{c}\text { Environmental and mineral exploration applications of } \\
\text { imaging spectroscopy; }\end{array}$
\end{tabular}

\begin{tabular}{lll}
\hline $\begin{array}{l}\text { Golden, } \\
\text { Colorado }\end{array}$ & Landscapes & National Crust Model
\end{tabular}


As a fairly new employee and contractor, I have begun to reach out to several USGS mission areas to advance our product.; Land Resources: Land Change Science Program

Landfire has reached out to EarthMAP in order to assist in understanding how our existing vegetation, disturbance and fuels mapping at $30 \mathrm{~m}$ could feed into those wishing to model scenarios involving habitats, vegetation structure, disturbance effects, and fuels characteristics. As part of the EarthMAP mindset, I feel that Landfire could potentially cooperate with EarthMAP via its extensive training datasets for vegetation and disturbance as well as 29 CONUS, AK and IA layers of vegetation, fuels, disturbance and fire regime spatial layers (https://landfire.gov/version_comparison.php). Separately, we have begun conversations with several efforts mapping annual herbaceous cover in the West to potentially improve upon our Mod-FIS product which typically depicts cheatgrass and other invasives. Our Mod-FIS product for the great basin adjusts fuel models seasonally for those wishing to model wildfire scenarios with current fuels data (https://landfire.gov/modfis.php).

\section{Geography}

Development with other government and international agencies outside of USGS

Core Science Systems: National Cooperative Geologic Mapping Program; Core Science Systems: National Geologic and Geophysical Data Preservation Program; Core Science Systems: National Geospatial Program; Core Science Systems: Science Analytics and Synthesis (SAS); Energy and Minerals: Mineral Resources; Land Resources: Land Change Science Program; Land Resources: National Land Imaging Program; Natural Hazards: Coastal \& Marine Hazards and Resources Program; Natural Hazards: Landslide Hazards
NGP Data Delivery and Visualization - https://www.usgs.gov/core-science-systems/ngp/tnmdelivery/

3DEP - https://www.usgs.gov/core-science-systems/ngp/3dep

NHD - https://www.usgs.gov/core-science-systems/ngp/national-hydrography

Geology

Core Science Systems: Science Analytics and Synthesis (SAS); Environmental Health: Toxic Substances Hydrology; and Resources: Land Change Science Program; Natural Hazards: Coastal \& Marine Hazards and Resources Program; Natural Hazards: Earthquake Hazards; Natural Hazards: Landslide Hazards

The names of these programs have changed through the years. I have worked with NAWQA Cycles I \& II, NAWQA-ACT, GWRP, WAUSP, Toxics Program, NRP, DODESP, Army Environmental Center, US Air Force (AFCEC);Core Science Systems: National Cooperative Geologic Mapping Program; Core Science Systems: National Geologic and Geophysical Data Preservation Program; Core Science Systems: National Geospatial Program; Energy and Minerals: Mineral Resources; Energy and Minerals: Energy Resources; Environmental Health: Toxic Substances Hydrology; Water Resources: Water Resources Availability Program; Water Resources: Water Resources Research Act Program
Core Science Systems: National Cooperative Geologic Mapping Program; Energy and Minerals: Mineral Resources
I'm helping NASA with the EMIT imaging spectrometer that will collect mineralogic information on dust-generating areas to help refine Earth System Models.

I've also played a major role in developing the USGS spectral library that has been used by scientist from diverse disciplines.

https://pubs.er.usgs.gov/publication/ofr20181115, https://doi.org/10.5066/P9Z6RC5L, https://doi.org/10.5066/P9X5ZX6Y, https://pdfs.semanticscholar.org/988b/ c89283cdf2fa0261157328c432ae505de45c.pdf?_ga=2.125801034.1972329237.16027740431731497904.1602774043 
Table 4.1. Summary of survey responses describing multidisciplinary projects.—Continued

[*Information in the table cells includes direct survey responses from individuals and have not been altered. Some abbreviations may reflect respondents understanding of commonly used abbreviations and some abbreviations are not defined. Due to the large list of abbreviations in this table, the abbreviations are listed at the beginning of this appendix.]

\begin{tabular}{|c|c|c|c|}
\hline Location & Integration disciplines & Skills & Capability \\
\hline $\begin{array}{l}\text { Salt Lake City, } \\
\text { Utah }\end{array}$ & Water & & Source-to-sink studies; \\
\hline $\begin{array}{l}\text { Denver, } \\
\quad \text { Colorado }\end{array}$ & Geochemistry, hazards & $\begin{array}{l}\text { Magmatism and deformation } \\
\text { of the earth's crust, and how } \\
\text { these processes influence the } \\
\text { formation and distribution of } \\
\text { natural resources and geologic } \\
\text { hazards }\end{array}$ & $\begin{array}{l}\text { 2D and 3D geologic map; magmatism and deformation } \\
\text { of the earth's crust, and how these processes influence } \\
\text { the formation and distribution of natural resources } \\
\text { and geologic hazards }\end{array}$ \\
\hline $\begin{array}{l}\text { Denver, } \\
\quad \text { Colorado }\end{array}$ & Water, contamination, human health & $\begin{array}{l}\text { Abandoned mines and quarries } \\
\text { contamination and pollution } \\
\text { human impacts } \\
\text { nonpoint-source pollution } \\
\text { environmental assessment }\end{array}$ & $\begin{array}{l}\text { Integrated Hyperspectral, Geophysical and Geochemical } \\
\text { Studies of Yellowstone National Park Hydrothermal } \\
\text { Systems; Salmon River Mountains Legacy Mining } \\
\text { Studies; Trace Metal Mobility in the Yellow Pine } \\
\text { Mining District, Idaho; influence of parent material, } \\
\text { geomorphology and hydrologic processes on soil } \\
\text { biogeochemistry. }\end{array}$ \\
\hline $\begin{array}{l}\text { Vancouver, } \\
\text { Washington }\end{array}$ & Water (paleohydrology) & Geologic mapping & Geology (volcanoes) \\
\hline
\end{tabular}

\begin{tabular}{|c|c|c|c|}
\hline Tucson, Arizona & Water & Geologic mapping & $\begin{array}{l}\text { Geologic framework and hydrogeology of the Rio Rico } \\
\text { and Nogales } 7.5^{\prime} \text { quadrangles }\end{array}$ \\
\hline $\begin{array}{l}\text { Lakewood, } \\
\text { Colorado }\end{array}$ & Landscapes, hazards (volcanism) & Geologic mapping & \\
\hline
\end{tabular}

\begin{tabular}{lccl}
\hline & \multicolumn{1}{c}{ Geology (vulcanology) } & \\
\hline $\begin{array}{l}\text { Vancouver, } \\
\text { Washington }\end{array}$ & Water, atmospheric dust & $\begin{array}{c}\text { Modeling and forecasting the } \\
\text { atmospheric movement of } \\
\text { volcanic ash during eruptions. }\end{array}$ & $\begin{array}{l}\text { Volcanic Ash Dispersion Model: daily simulations to } \\
\text { anticipate where ash clouds may move or deposits } \\
\text { might land. dynamics of explosive volcanic eruptions, } \\
\text { and in the physical processes that govern them. In } \\
\text { recent years I have specialized in modeling and } \\
\text { forecasting the atmospheric movement of volcanic } \\
\text { ash during eruptions. }\end{array}$ \\
\hline
\end{tabular}

\begin{tabular}{llll}
\hline & & Geophysics & \\
\hline Jackson, & Water & Filtering gravity data & Filtering gravity data \\
Mississippi & &
\end{tabular}

\begin{tabular}{lcc}
\hline Pasadena, & Landscapes & ALERT system \\
California & & Advanced national seismic system, earthquake early \\
(collocated & & \\
with Caltech) & &
\end{tabular}


USGS Collaboration

Energy and Minerals: Mineral Resources

Core Science Systems: National Cooperative Geologic Mapping Program; Core Science Systems: National Geospatial Program; Energy and Minerals: Mineral Resources

\section{Relevant projects}

Lithium from Source to Sink: Genesis and Evolution of Li Brines and Clays: The project aims to evaluate the Great Basin and surrounding regions for the components of the lithium brine and clay model by tracing the lithium pathway from source to sink.

Our team is working to making $2 \mathrm{D}$ and $3 \mathrm{D}$ geologic map data readily accessible for anyone who needs it, whether for Earthmap or anything else.

https://www.usgs.gov/centers/gecsc/science/geologic-framework-intermountain-west?qtscience_center_objects $=0 \#$ qt-science_center_objects
Water Mission Area \& ID-WSC; unsure of program; Energy and Minerals: Mineral Resources https://www.usgs.gov/energy-and-minerals/mineral-resources-program/science/integratedhyperspectral-geophysical-and?qt-science_center_objects=0\#qt-science_center_objects

https://www.usgs.gov/energy-and-minerals/mineral-resources-program/science/salmon-rivermountains-legacy-mining-studies?qt-science_center_objects=9\#qt-science_center_objects
Natural Hazards: Volcano Hazards; Core Science Systems: National Geologic and Geophysical Data Preservation Program; Core Science Systems: Science Analytics and Synthesis (SAS); Natural Hazards: Earthquake Hazards; Natural Hazards: Landslide Hazards

Core Science Systems: National Cooperative Geologic Mapping Program

Natural Hazards: Volcano Hazards (this USGS Program seems to have been omitted from the survey); Core Science Systems: National Cooperative Geologic Mapping Program; Core Science Systems: National Geologic and Geophysical Data Preservation Program; Core Science Systems: National Geospatial Program; Energy and Minerals: Mineral Resources; Natural Hazards: Landslide Hazards

Core Science Systems: Science Analytics and Synthesis (SAS); Natural Hazards: Emergency Management
See comments above

https://pubs.er.usgs.gov/publication/sir20185062

The USGS National Cooperative Geologic Mapping Program within CSS has extensive cooperative agreements with State Geological Surveys. I have experience with coordinating NCGMP project activities with State partners to leverage geologic expertise outside of the USGS and develop collaborative support of USGS NCGMP goals.
Geology (vulcanology)

https://vsc-ash.wr.usgs.gov/ash3d-gui/\#!/ (the USGS Ash3d tephra model)

\section{Geophysics}

Core Science Systems: National Geologic and Geophysica Data Preservation Program; Water Resources: Water Observing Systems Program; Water Resources: Water Resources Research Act Program
Master's Thesis on Filtering Gravity Data for the Kentland Indiana Dome anamoly

https:/www.usgs.gov/natural-hazards/earthquake-hazards/shakealert

https:/www.usgs.gov/natural-hazards/earthquake-hazards/anss-advanced-national-seismicsystem?qt-science_support_page_related_con=4\#qt-science_support_page_related_con 
Table 4.1. Summary of survey responses describing multidisciplinary projects.—Continued

[*Information in the table cells includes direct survey responses from individuals and have not been altered. Some abbreviations may reflect respondents understanding of commonly used abbreviations and some abbreviations are not defined. Due to the large list of abbreviations in this table, the abbreviations are listed at the beginning of this appendix.]

\begin{tabular}{clll}
\hline \multicolumn{1}{c}{ Location } & \multicolumn{1}{c}{ Integration disciplines } & \multicolumn{1}{c}{ Skills } & \multicolumn{1}{c}{ Capability } \\
\hline Denver, & Hydrology, permafrost, soil, climate & $\begin{array}{l}\text { Ground-based and airborne } \\
\text { Colorado }\end{array}$ & geophysical methods; \\
& computational methods for & Mississippi Alluvial Plan water availability; Alaska \\
& uncertainty quantification \\
& in geophysical datasets \\
& and associated geologic or \\
& hydrologic interpretations
\end{tabular}

\begin{tabular}{llcc}
\hline $\begin{array}{l}\text { Denver, } \\
\text { Colorado }\end{array}$ & Ecosystems (trees); soils, climate & $\begin{array}{l}\text { Passive seismic techniques for } \\
\text { novel applications related to } \\
\text { geologic characterization, } \\
\text { groundwater, and cold-region } \\
\text { processes }\end{array}$ & $\begin{array}{c}\text { Biology, geochemistry, soil science, and geophysics to } \\
\text { better understand permafrost environments }\end{array}$ \\
\hline Rolla, Missouri & Energy and minerals & Geospatial & \\
& & Urbanization mapping & $\begin{array}{c}\text { Geospatial data, Landscapes, Energy, and minerals } \\
\text { mapping }\end{array}$
\end{tabular}

\begin{tabular}{ccc}
\hline $\begin{array}{c}\text { Anchorage, } \\
\text { Alaska }\end{array}$ & Water & National Hydrography \\
Management and Planning lead & NHD, mapping coordination
\end{tabular}

\begin{tabular}{llcl}
\hline $\begin{array}{c}\text { Lakewood, } \\
\text { Colorado }\end{array}$ & Data management, geology & $\begin{array}{c}\text { Data management and analysis, } \\
\text { GIS, spatial data analysis, and } \\
\text { engineering geology. }\end{array}$ & GIS, data management \\
\hline $\begin{array}{c}\text { Moffett Field, } \\
\text { California }\end{array}$ & Energy, minerals & GiS support & $\begin{array}{c}\text { Mapping hazards; GIS Coordinator \& Geospatial } \\
\text { Systems Architect }\end{array}$
\end{tabular}

\section{Geospatial data}

\begin{tabular}{cccc}
\hline Rolla, Missouri & Water, landscapes & NHD autonomous validation & $\begin{array}{c}\text { NHD, channel elevations, remote sensing; autonomous } \\
\text { validation of elevation-derived hydrographic features } \\
\text { using remote sensing data to update the NHD }\end{array}$ \\
\hline $\begin{array}{c}\text { Raleigh, North } \\
\text { Carolina }\end{array}$ & Water & $\begin{array}{c}\text { Land use and water demand } \\
\text { projections }\end{array}$ & $\begin{array}{c}\text { FUTure Urban-Regional Environment Simulation } \\
\text { (FUTURES) framework; Land use simulations; } \\
\text { urbanization and climate }\end{array}$
\end{tabular}


USGS Collaboration

Core Science Systems: Science Analytics and Synthesis (SAS); Energy and Minerals: Mineral Resources; Land Resources: Land Change Science Program; Water Resources: Water Resources Availability Program

\section{Relevant projects}

Geophysics lead for MAP project (https//www2.usgs.gov/water/lowermississippigulf/map/), integrates geophysics, hydrology, and economics in a to US agricultural region

- permafrost research through USGS LandCarbon (https://www.usgs.gov/ecosystems/landchange-science-program/science/landcarbon?qt-science_center_objects=0\#qt-science_center_ objects) and Yukon River Basin project integrated hydrology, remote sensing, soil science, geophysics, linked with NASA ABoVE program

- jointly funded by USGS MRP and DOE as a partner in the LBNL Watershed Science Focus area (https://watershed.lbl.gov/) studying geological controls on metal transport in mineralized watersheds

Core Science Systems: Science Analytics and Synthesis (SAS); Ecosystems: Environments; Land Resources: Land Change Science Program; Water Resources: Water Resources Research Act Program
I may have gotten some of these programs wrong, but I work with a diverse range of scientists to combine biology, geochemistry, soil science, and geophysics to better understand permafrost environments.

\section{Geospatial}

Core Science Systems: National Geospatial Program; Core Science Systems: Science Analytics and Synthesis (SAS); Energy and Minerals: Mineral Resources; Land Resources: Land Change Science Program; Land Resources: National Land Imaging Program
- U.S. Bureau of Land Management, 1998, Mosquito Creek Lake Proposed Planning Analysis/ Environmental Assessment (MDO- EA98-013), October 1998, in cooperation with U.S. Army Corps of Engineers, Pittsburgh District, and Ohio Department of Natural Resources. D.E Varanka, Contributor of written sections.

- Varanka, D., 2002, Strategic Vision for the U.S. Geological Survey in the Great Lakes-St. Lawrence Region, 2001-2002, Contributing Author. U.S. Geological Survey, Open File Report 02-193.

- Varanka, D.E., 2006, National Trends Regarding Aggregate Materials for Urban Development, in Rates, Trends, Causes, and Consequences of Urban Land-Use Change in the United States: USGS Professional Paper 1726, pp. 45-54.

- Varanka, D.E., and Shaver, D.K., 2007, Land-Use Change Trends in the Interior River Lowlands Ecoregion: U.S. Geological Survey Scientific Investigations Report 2007-5145, p. 12, at URL http://pubs.usgs.gov/sir/2007/5145/.

- Varanka, D.E., 2010, Interpolating a Consumption Variable for Scaling and Generalizing Potential Population Pressure on Urbanizing Natural Areas, in Jiang, B., and Yao, X., eds., Geospatial Analysis and Modeling of Urban Structure and Dynamics: New York, Springer Publishing Co., p. 293-310.

Water Resources: Geo-Intelligence Branch; Core Science Systems: National Geospatial Program; Core Science Systems: Science Analytics and Synthesis (SAS)

As Management and Planning Lead for National Hydrography Datasets (https://www.usgs. gov/NHD), I regularly work and coordinate with scientists across many Mission Areas, particularly Water Resources and Ecosystems. In my previous positions as Coordinator for Arctic Science and Plans and Alaska Geospatial Liaison, I worked and coordinated with scientists from all of the mission areas.

Core Science Systems: National Geospatial Program

https://www.usgs.gov/core-science-systems/national-geospatial-program

\section{Geospatial (NCGMP)}

Previously worked for USFS and NASA - across similar topics in this list. Wildlife, land management, water included.; Core Science Systems: National Cooperative Geologic Mapping Program; Ecosystems: Environments; Energy and Minerals: Mineral Resources; Energy and Minerals: Energy Resources; Natural Hazards: Landslide Hazards https://www.usgs.gov/staff-profiles/amber-wittner - Enterprise GIS for NCGMP Community is currently under development. My profile page discusses my work with scientists from many disciplines, in addition to my NCGMP work.

Geospatial data

Core Science Systems: National Geospatial Program; Water Resources: Water Observing Systems Program

Land Resources: Land Change Science Program; Water Resources: Water Resources Availability Program
Project_1: https://www.sciencebase.gov/catalog/item/550b2a87e4b02e76d7593fb9 Child project_1: https://www.sciencebase.gov/catalog/item/5e4d5fa7e4b0ff554f6d20ba Project_2: https://www.sciencebase.gov/catalog/item/5bc4ba39e4b0fc368eba0489 
Table 4.1. Summary of survey responses describing multidisciplinary projects.-Continued

[*Information in the table cells includes direct survey responses from individuals and have not been altered. Some abbreviations may reflect respondents understanding of commonly used abbreviations and some abbreviations are not defined. Due to the large list of abbreviations in this table, the abbreviations are listed at the beginning of this appendix.]

\begin{tabular}{cccc}
\hline \multicolumn{1}{c}{ Location } & \multicolumn{1}{c}{ Integration disciplines } & Skills & Capability \\
\hline $\begin{array}{c}\text { Denver, } \\
\text { Colorado }\end{array}$ & Energy (wind), landscapes & Data management & Wind turbines database \\
\hline $\begin{array}{c}\text { Alaska Science } \\
\text { Center, Alaska }\end{array}$ & Genetics, microbiology & $\begin{array}{c}\text { Data steward for the Molecular } \\
\text { Ecology Laboratory }\end{array}$ & $\begin{array}{c}\text { Data steward for the Molecular Ecology Laboratory } \\
\text { ensuring compliance with data reporting requirements } \\
\text { Sample archival }\end{array}$ \\
& & & $\begin{array}{l}\text { Marker development and optimization } \\
\text { Application of novel techniques }\end{array}$ \\
& & & Population genetic data generation \\
\hline & $\begin{array}{c}\text { Coastal, Aerial Imaging and Mapping } \\
\text { group (AIM) }\end{array}$ & $\begin{array}{c}\text { Post-disaster data collection and } \\
\text { analysis; UAS/AI/ML }\end{array}$ & $\begin{array}{c}\text { UAS/AI/ML; post-disaster data collection and analysis } \\
\text { as well as guidance on processing, analysis and } \\
\text { publication of large imagery dataset }\end{array}$
\end{tabular}

\begin{tabular}{|c|c|c|c|}
\hline \multicolumn{4}{|c|}{ Geothermal energy } \\
\hline $\begin{array}{l}\text { Albuquerque, } \\
\text { New Mexico }\end{array}$ & Groundwater hydrology, & $\begin{array}{l}\text { Geothermal mapping, } \\
\text { electomagnetic geophysics }\end{array}$ & Geothermal; transboundary aquifer (QW, geothermal) \\
\hline
\end{tabular}

Hazards (landslides)

\begin{tabular}{llcl}
\hline & Hazards (landslides) & \\
\hline $\begin{array}{l}\text { Golden, } \\
\text { Colorado }\end{array}$ & Water & LiDAR interp, imagery interp & $\begin{array}{c}\text { Landslide hazards, LiDAR, rockslides, volcanic hillside } \\
\text { instability }\end{array}$
\end{tabular}

\section{IT}

San Juan, Puerto Data applications $\quad$ Decoders, mapping, data display $\quad$ Data acquisition, ALERT systems,
Rico

\begin{tabular}{ccc}
\hline Denver, & Hazards, human health, ecosystems & Web services; Community for \\
Colorado & Data Integration (CDI) Risk \\
& Map Project
\end{tabular}

Community for Data Integration (CDI) Risk Map

Project is developing modular tools and services to benefit a wide group of scientists and managers that deal with various aspects of risk research and planning; a spatial database of hazards and assets, an API to query the data, web services with Geoserver. Human health, ecosystem health, wildland fire, geophysical, meteorological, technological, and adversarial threats

\begin{tabular}{ccc}
\hline Lakewood, & Energy (petroleum) & $\begin{array}{c}\text { Scientific data management and } \\
\text { governance }\end{array}$ \\
Colorado &
\end{tabular}

Central Energy Resources Science Center (CERSC) addresses national and global energy geoscience issues and conducts interdisciplinary research on energy systems; World Petroleum Assessment; National Petroleum Reserve, Alaska Assessment 
USGS Collaboration

Relevant projects

Energy and Minerals: Energy Resources

https://doi.org/10.5066/F7TX3DN0.

Core Science Systems: National Geospatial Program

No specific links, but have had several detailed interactions with JC Nelson, Daniel Wieferich, Alan Rea and Kimberly Reed regarding mapping tools for automated non-subjective assignment of samples to geospatial polygons and desires to visualize/link projects to clickable maps for websites... (I have no arcGIS skills, but see the potential...)

Land Resources: National Land Imaging Program; Natural Hazards: Coastal \& Marine Hazards and Resources Program; Water Resources: Water Observing Systems Program

Along with our Aerial Imaging and Mapping Group, I have worked with the National UAS Program Office and other UAS pilots across the bureau to provide post-disaster data collection and analysis as well as guidance on processing, analysis and publication of large imagery dataset. Recent involvement with a couple of the NER Capabilities Teams has also brought about potential for increased collaboration with scientists and technicians across mission areas in the fields of UAS and AI/ML.

\section{Geothermal energy}

Energy and Minerals: Energy Resources

I find the list of mission areas and programs a bit confusing since it seems to change frequently. Overall, I work on local reimbursable projects in addition to appropriated projects. About $1 / 2$ of my salary comes from the USGS Geothermal Resources Investigations Project (GRIP), which is part of the USGS Energy Resources Program. Additionally, about 1/4 of my salary is funded by the congressionally funded Transboundary Aquifer Assessment Program (TAAP) -- not sure where that fits in regarding the list above. Here are the links to those:

GRIP: https://www.usgs.gov/energy-and-minerals/energy-resources-program/science/ geothermal?qt-science_center_objects $=0 \#$ qt-science_center_objects

TAAP: https://www.usgs.gov/centers/nm-water/science/transboundary-aquifer-assessmentprogram-taap?qt-science_center_objects=0\#qt-science_center_objects

Hazards (landslides)

Volcano Hazards; Land Resources: National Land Imaging Program; Natural Hazards: Earthquake Hazards; Natural Hazards: Landslide Hazards

I have participated in several projects in recent years, in which we in the landslide hazards program have relied on imagery and lidar data provided by the USGS or partners. The most recent example is the assessment of landslide hazards in Puerto Rico in the aftermath of Hurricane Maria. We have also collaborated with colleagues from the earthquake hazards program on study of rock avalanches and with colleagues from the volcano hazards program on monitoring of unstable hillsides.

\section{IT}

Extensive experience working on understanding local cooperators needs of data and developed applications integrating data for them, including NOAA, and local networks. Development includes decoder of radio transmitting transmissions for ALERT network, and mapping interface to display data.

Core Science Systems: Science Analytics and Synthesis (SAS); Land Resources: Land Change Science Program
Helped to administer/manage SAS/Western Geographic collab in 2018: CDI Risk Map: https:// www.sciencebase.gov/catalog/item/5b91a0c2e4b0702d0e808bb2;

With all answers on this page, struggled with "I have some experience with this and have done this" or "I have helped others to do this and have been involved with the project but others were the experts." I was generous with my answers...
Energy and Minerals: Mineral Resources; Energy and Minerals: Energy Resources https://www.usgs.gov/centers/cersc, https://certmapper.cr.usgs.gov/data/apps/worldenergy/?resource=continuous, https://certmapper.cr.usgs.gov/data/apps/noga-drupal/, https:// certmapper.cr.usgs.gov/data/apps/npra/ 
Table 4.1. Summary of survey responses describing multidisciplinary projects.-Continued

[*Information in the table cells includes direct survey responses from individuals and have not been altered. Some abbreviations may reflect respondents understanding of commonly used abbreviations and some abbreviations are not defined. Due to the large list of abbreviations in this table, the abbreviations are listed at the beginning of this appendix.]

\begin{tabular}{|c|c|c|c|}
\hline Location & Integration disciplines & Skills & Capability \\
\hline \multicolumn{4}{|c|}{ Landscape ecology } \\
\hline $\begin{array}{l}\text { Seattle, } \\
\text { Washington }\end{array}$ & Wildlife (fish) & $\begin{array}{l}\text { Landscape scenario modeling, } \\
\text { spatial analysis, remote } \\
\text { sensing, GIS }\end{array}$ & $\begin{array}{l}\text { Landscape ecology, riverine landscapes, watershed } \\
\text { processes, ecological scaling, water quality, fish } \\
\text { habitat, land use/land cover change, landscape } \\
\text { scenario modeling, spatial analysis, remote sensing, } \\
\text { GIS }\end{array}$ \\
\hline
\end{tabular}

\begin{tabular}{|c|c|c|c|}
\hline \multicolumn{4}{|c|}{ Landscapes } \\
\hline $\begin{array}{l}\text { Denver, } \\
\quad \text { Colorado }\end{array}$ & Water, wildlife & Satellite imagery Mapping & $\begin{array}{l}\text { PRMS, Prairie Potholes; surface depression storage for } \\
\text { conterminous US; satellite imagery to understand } \\
\text { how ecosystems change over time. She is particularly } \\
\text { interested in surface water dynamics and disturbance } \\
\text { events, such as fire and insect outbreaks. }\end{array}$ \\
\hline Tucson, Arizona & Ecosystems (flora), Water (drought) & $\begin{array}{l}\text { Fallow-land Algorithm based } \\
\text { on Neighborhood and } \\
\text { TemporalAnomalies (FANTA) } \\
\text { to map planted versus fallowed } \\
\text { croplands usingMODIS }\end{array}$ & $\begin{array}{l}\text { Mapping When and Where Invasive Buffelgrass } \\
\text { is Green at Saguaro National Park in Arizona; } \\
\text { Fallow-land Algorithm based on Neighborhood and } \\
\text { TemporalAnomalies (FANTA) to map planted versus } \\
\text { fallowed croplands using MODIS data to assist in } \\
\text { drought studies }\end{array}$ \\
\hline $\begin{array}{l}\text { Fort Collins, } \\
\text { Colorado }\end{array}$ & Ecosystems, water, energy & $\begin{array}{l}\text { Integration science, } \\
\text { interdisciplinary, multi-scale }\end{array}$ & Wyoming Landscape Conservation Initiative (WLCI) \\
\hline
\end{tabular}

\begin{tabular}{lccc}
\hline & \multicolumn{1}{c}{ Minerals } & \\
\hline $\begin{array}{c}\text { Golden, } \\
\text { Colorado }\end{array}$ & Socio-economics, hazards & Quantifying risk & $\begin{array}{c}\text { Mineral supply chains; Natural hazards and mineral } \\
\text { commodity supply: Quantifying risk of earthquake } \\
\text { disruption to South American copper supply }\end{array}$ \\
\hline $\begin{array}{c}\text { Lakewood, } \\
\text { Colorado }\end{array}$ & Wildlife (fish), habitat & Science Analytics and Synthesis & \\
& & $\begin{array}{c}\text { Develop, manage, and analyze } \\
\text { national scale biogeographic } \\
\text { data. }\end{array}$ & First not found; National Fish Habitat Partnership \\
& &
\end{tabular}

\section{Sediment}

\begin{tabular}{ccc} 
& \multicolumn{2}{c}{ Sediment } \\
\hline $\begin{array}{c}\text { Flagstaff, } \\
\text { Arizona }\end{array}$ & Geophysics & LiDAR interp, \\
processes
\end{tabular}

\begin{tabular}{cccc}
\hline & Sediment geochronology & \\
\hline $\begin{array}{c}\text { Lakewood, } \\
\text { Colorado }\end{array}$ & Water & $\begin{array}{c}\text { Sediment geochoronology } \\
\text { laboratory }\end{array}$ & sediment dating \\
\end{tabular}

\begin{tabular}{|c|c|c|c|}
\hline \multicolumn{4}{|c|}{ Socioeconomics } \\
\hline $\begin{array}{l}\text { Denver, } \\
\quad \text { Colorado }\end{array}$ & Ecosystems, water use, species & Cost-benefit analysis & $\begin{array}{l}\text { Cost-benefit of sustaining species; Eco services national } \\
\text { and local; reanalyzing and predicting United States } \\
\text { water use }\end{array}$ \\
\hline
\end{tabular}




\section{Landscape ecology}

Core Science Systems: National Geospatial Program; Core Science Systems: Science Analytics and Synthesis (SAS); Ecosystems: Environments; Ecosystems: Fisheries; Ecosystems: Status \& Trends; Land Resources: Land Change Science Program; Water Resources: Water Resources Availability Program; Water Resources: Water Observing Systems Program

Land Resources: Land Change Science Program; Water Resources: Integrated Water Prediction Program
As a scientist in Ecosystems, I collaborate with people in Water, Geology, and Geospatial/ Geography areas, but I have to confess that I am not familiar enough with all of the names of the mission areas and programs to be very confident about my selections. For example, I collaborate a lot with scientists in Water, but I don't really know what mission areas and programs they are associated with.
Ecosystems: Invasive Species; Land Resources: Land Change Science Program

\section{Landscapes}

https://onlinelibrary.wiley.com/doi/full/10.1002/hyp.11416?casa token=LKqdSWO81rYAAAAA\%3Ad-pkUXI9AXeDWl-T7tqAENzC1cTUXLlfan bhyTlCXilRZ4CFzfUn80aqGrGGWVLLJW109Fj9vVExCs

https://onlinelibrary.wiley.com/doi/full/10.1111/1752-1688.12826 https://www.usgs.gov/centers/wgsc/science/buffelgrass?qt-science_center_objects=0\#qtscience_center_objects

https://pubs.er.usgs.gov/publication/70186183

https://usanpn.org/data/forecasts/Buffelgrass

http://bgwebportal.eastus.cloudapp.azure.com/index.html\#/home
Core Science Systems: Science Analytics and Synthesis (SAS); Ecosystems: Energy and Wildlife; Ecosystems: Status \& Trends
I coordinate USGS science activities in support of Wyoming Landscape Conservation Initiative (WLCI). This includes integrating science across USGS disciplines and working at multiple spatial and temporal scales. I typically don't do the models actual models but do guide or facilitate this work. I am also involved with ensuring our body of science is being integrated and supporting WLCI decisions (conservation actions and land management decisions related to oil and gas development).

\section{Minerals}

Energy and Minerals: Mineral Resources; Natural Hazards: Earthquake Hazards

\section{Natural Hazards + Energy and Minerals:}

https://www.doi.gov/ocl/mineral-supply-chains-impact https://doi.org/10.1016/j.resourpol.2019.101430

\section{Science Analytics and Synthesis}

Core Science Systems: National Geospatial Program; Core Science Systems: Science Analytics and Synthesis (SAS); Ecosystems: Fisheries; Ecosystems: Invasive Species; Ecosystems: Status \& Trends; Water Resources: Integrated Water Prediction Program

https://doi.org/10.5066/P9KRWCFL, https://www.sciencebase.gov/drip/,

https://ccviewer.wim.usgs.gov/FishVis/\#,

Work with the National Fish Habitat Partnership which has participation spanning several groups across USGS (http://www.fishhabitat.org/).

\section{Sediment}

Coastal Marine; Natural Hazards: Landslide Hazards

See work by Brian Collins, David Bedford, Skye Corbett on using lidar to evaluate geomorphic change at archaeological sites in Grand Canyon National Park that is related to the operations of Glen Canyon Dam. Also work by Amy Draur/Amy East on aeolian processes affecting Grand Canyon archaeological sites that are linked to operations of Glen Canyon Dam.

Sediment geochronology

I have linked labs to offer several geochronology dating services from 137 cesium to radiocarbon to luminescence. I also link to gamma spectrometry, ICPMS, and particle size analyses

Energy and Minerals: Science \& Decisions Center; Land Resources: Land Change Science Program; Water Resources: Water Resources Availability Program
If you want to date or describe sediment I can help.

\section{Socioeconomics}

Three Powell Center working groups (first two as a co-PI):

https://www.usgs.gov/centers/powell-ctr/science/accounting-us-ecosystem-services-nationaland-subnational-scales?qt-science_center_objects $=0 \# q t$-science_center_objects

https://www.usgs.gov/centers/powell-ctr/science/reanalyzing-and-predicting-us-water-use-usingeconomic-history-and?qt-science_center_objects $=0 \#$ qt-science_center_objects

https://www.usgs.gov/centers/powell-ctr/science/animal-migration-and-spatial-subsidiesestablishing-a-framework?qt-science_center_objects=0\#qt-science_center_objects 
Table 4.1. Summary of survey responses describing multidisciplinary projects.-Continued

[*Information in the table cells includes direct survey responses from individuals and have not been altered. Some abbreviations may reflect respondents understanding of commonly used abbreviations and some abbreviations are not defined. Due to the large list of abbreviations in this table, the abbreviations are listed at the beginning of this appendix.]

\begin{tabular}{llll}
\hline \multicolumn{1}{c}{ Location } & \multicolumn{1}{c}{ Integration disciplines } & \multicolumn{1}{c}{ Skills } & Capability \\
\hline Reston, Virginia & Hazards & SHIRA model & Shira risk modeling \\
\hline $\begin{array}{l}\text { Denver, } \\
\text { Colorado }\end{array}$ & Water, landscapes, wildlife & Structured decision making & Structured decisions, socio-economics, communications
\end{tabular}

Colorado

UAS Remote sensing

\begin{tabular}{llll}
\hline $\begin{array}{c}\text { Lakewood, } \\
\text { Colorado }\end{array}$ & Landscapes, biology & UAS & UAS services
\end{tabular}

\begin{tabular}{|c|c|c|}
\hline & Water & \\
\hline Portland, Oregon Hazards & Remote Sensing & $\begin{array}{l}\text { Habitat metrics, dam management, ESA salmonids, } \\
\text { Remote sensing }\end{array}$ \\
\hline
\end{tabular}

\begin{tabular}{|c|c|c|c|}
\hline $\begin{array}{l}\text { Raleigh, North } \\
\text { Carolina }\end{array}$ & $\begin{array}{l}\text { Socioeconomics, habitat, ecosystem } \\
\text { services }\end{array}$ & SPARROW model, & $\begin{array}{l}\text { Floodplain Eco processes in DRB; Stormwater\& } \\
\text { groundwater: SPARROW for North Carolina }\end{array}$ \\
\hline
\end{tabular}

\begin{tabular}{|c|c|c|c|}
\hline Troy, New York & Coastal/marine & $\begin{array}{l}\text { Hydrodynamic modeling, } \\
\text { CoSMOS Modeling }\end{array}$ & compound flooding in cities, mapping coastal flooding \\
\hline
\end{tabular}


USGS Collaboration

Relevant projects

Department of the Interior's Strategic Hazard Identification https://www.doi.gov/emergency/shira and Risk Assessment Project

Water science centers; WMA IIDD; Core Science Systems: I wasn't sure how to answer that question, so I just listed all of the organizations with which I Science Analytics and Synthesis (SAS); Ecosystems: Energy and Wildlife; Ecosystems: Environments; Ecosystems: Invasive Species; Ecosystems: Status \& Trends; Energy and Minerals: Mineral Resources; Energy and Minerals: Energy Resources; Environmental Health: Contaminant Biology; Land Resources: Land Change Science Program

New to USGS. Yes to the question in its general intent, no to all specifics by USGS Mission area, except that I have worked a total of weeks in groups with people across USGS Mission areas as part of a larger interdisciplinary effort (for years before starting at USGS) have worked on collaborative projects. Not all together on any one project

NPS and EPA's Air Quality and Ecosystem Services workshop from which five papers (I was lead author on one, with authorship across 2-3 agencies). US Natural Capital Accounting working group led by $\mathrm{C}$ Shapiro and $\mathrm{K}$ Bagstad, involving many agencies and top NGOs like the World Bank. Work with UN Statistics Division on Ecosystem Accounting. Some smaller efforts but all of those produce publications. My name will be on no UN publication, but certain of my presentation materials or co-authored interim products may be on the related UN SEEA website.

\section{UAS Remote sensing}

Core Science Systems: National Geospatial Program; Core Science Systems: Science Analytics and Synthesis

Our USGS National UAS Project Office works with any and all USGS and USDOI scientists to (SAS); Environmental Health: Contaminant Biology; Land Resources: National Land Imaging Program; Natural Hazards: Coastal \& Marine Hazards and Resources Program; Natural Hazards: Earthquake Hazards; Natural Hazards: Geomagnetism; Natural Hazards: Landslide Hazards; Water Resources: Water Observing Systems Program

\section{Water}

Ecosystems: Fisheries
We don't yet have a website, but I frequently work with biologists from USGS Cooperative Unit (Oregon State University), USGS Fisheries Research, and USGS Forest and Rangeland to integrate physical habitat metrics - from sources from numerical modeling, temperature modeling, and remote sensing to inform how dam management and river restoration affects ESA listed salmonids

Ecosystems: Environments; Environmental Health: Contaminant Biology; Land Resources: Land Change Science Program

Floodplain ecosystem services in the Chesapeake and Delaware, https://www.usgs.gov/centers/ sa-water/science/quantifying-floodplain-ecological-processes-and-ecosystem-servicesdelaware
Urban stormwater management, https://www.usgs.gov/centers/sa-water/science/understandingeffects-stormwater-management-practices-water-quality-and?qt-science_center_objects=0\#qtscience_center_objects

SPARROW Modeling for North Carolina Watersheds, https://www.usgs.gov/centers/sa-water/ science/sparrow-modeling-north-carolina-watersheds?qt-science_center_objects=0\#qtscience_center_objects

Natural Hazards: Coastal \& Marine Hazards and Resource Program; Water Resources: Integrated Water Prediction Program

Core Science Systems: Science Analytics and Synthesis (SAS); Ecosystems: Environments; Ecosystems: Fisheries; Natural Hazards: Emergency Management; Water Resources: Water Resources Availability Program; Water Resources: Water Observing Systems Program; Water Resources: Integrated Water Prediction Program; Water Resources: Water Resources Research Act Program
No results yet but have started to collaborate between water and natural hazards to investigate compound flooding in New York City area, hopefully funding and results coming soon!

https://www.usgs.gov/centers/wy-mt-water/science/living-edge-predicting-effects-climatechange-native-fishes-northern?qt-science_center_objects $=0 \#$ qt-science_center_objects https://www.usgs.gov/centers/wy-mt-water/science/ecoflows-understanding-streamflowdynamics-small-mountain-streams?qt-science_center_objects=0\#qt-science_center_objects

https://www.usgs.gov/centers/cdi/science/ice-ice-jam-hazard-mobile-friendly-website?qtscience_center_objects $=0 \#$ qt-science_center_objects

https://test.wim.usgs.gov/icejams/\#/home

https://www.usgs.gov/centers/cdi/science/development-recommended-practices-and-workflowpublishing-digital-data-through?qt-science_center_objects=0\#qt-science_center_objects 
Table 4.1. Summary of survey responses describing multidisciplinary projects.—Continued

[*Information in the table cells includes direct survey responses from individuals and have not been altered. Some abbreviations may reflect respondents understanding of commonly used abbreviations and some abbreviations are not defined. Due to the large list of abbreviations in this table, the abbreviations are listed at the beginning of this appendix.]

\begin{tabular}{lllc}
\hline \multicolumn{1}{c}{ Location } & \multicolumn{1}{c}{ Integration disciplines } & Skills & Capability \\
\hline $\begin{array}{c}\text { Pembroke, New } \\
\text { Hampshire }\end{array}$ & Human health, contaminants & Machine learning & $\begin{array}{c}\text { Connecting environmental geochemistry with human } \\
\text { and ecosystem health, and using machine learning } \\
\text { models to understand, estimate, and predict } \\
\text { contaminant occurrence and water use }\end{array}$ \\
\hline $\begin{array}{c}\text { Baltimore, } \\
\text { Maryland }\end{array}$ & Landscapes & & Ches Bay, topobathy LiDAR, AI/ML
\end{tabular}

\begin{tabular}{ccc}
\hline $\begin{array}{c}\text { Pembroke, New } \\
\text { Hampshire }\end{array}$ & Geography NHD, SPARROW & SPARROW, NHD user guide; nutrients
\end{tabular}

\begin{tabular}{|c|c|c|c|}
\hline $\begin{array}{l}\text { Springfield, } \\
\text { Missouri }\end{array}$ & Ecosystems (trees) & $\begin{array}{l}\text { Mobile phone Apps; source } \\
\text { tracking, GW modeling }\end{array}$ & $\begin{array}{l}\text { Oil plume in sediments, } \mathrm{AI} / \mathrm{ML} \text {; use of trees to } \\
\text { characterize subsurface contamination, measuring the } \\
\text { subsurface sampling volume associated with trees, } \\
\text { and using trees as indicators of vapor-intrusion risk. } \\
\text { My other interests are in chemical fate and transport, } \\
\text { Python programming, development of mobile phone } \\
\text { applications, application of microbial source tracking, } \\
\text { and groundwater modeling }\end{array}$ \\
\hline
\end{tabular}


Energy and Minerals: Energy Resources; Environmental Health: Toxic Substances Hydrology; Water Resources: Water Resources Availability Program https://www.usgs.gov/centers/powell-ctr/science/linking-environmental-and-public-health-dataevaluate-health-effects?qt-science_center_objects $=0 \#$ qt-science_center_objects

https://www.usgs.gov/mission-areas/environmental-health/science/energy-science-team?qtscience_center_objects $=0 \#$ qt-science_center_objects

Core Science Systems: National Geospatial Program; Ecosystems: Fisheries; Water Resources: Water Resources Availability Program; Water Resources: Water Observing Systems Program

Core Science Systems: National Cooperative Geologic Mapping Program; Core Science Systems: National Geospatial Program; Environmental Health: Toxic Substances Hydrology; Water Resources: Water Resources Availability Program; Water Resources: Water Observing Systems Program; Water Resources: Water Resources Research Act Program

Collaborative projects with USGS Chesapeake Bay Studies Priority Ecosystems, crossmission area topobathymetric lidar collections along the Potomac River, other Regional multidisciplinary capability team participation such as the UAS Capability Team and the AI/ ML Capability Team

https://water.usgs.gov/GIS/metadata/styles/landingPage/national_MOHP_Predictor.xml https://www.sciencebase.gov/catalog/item/5b4e34dfe4b06a6dd180272e

Published user's guide for NHDplus HR https://doi.org/10.3133/ofr20191096

http://www.horizon-systems.com/NHDPlus/applications.php

https://pubs.usgs.gov/pp/1833/pp1833.pdf, pages 23-26, 38-40, 77, 79-104

http://onlinelibrary.wiley.com/doi/10.1111/1752-1688.12389/epdf

http://gispub4.epa.gov/Merganser
SPARROW Model Applications and Future Scenarios: I continue to work with other scientists both inside and outside the Survey with the aim of applying SPARROW models to help address important issues associated with excess nutrient loadings. Future scenarios being developed include an article on the anticipated reduction of the delivery of nitrogen to estuaries and to lakes in response to the Clean Air Interstate Rule by making use of the anticipated 2020 CMAQ predictions for atmospheric deposition in the year 2020. Also as part of the Powell Center River Corridor group I'm involved in determining reference conditions (i.e. without the anthropomorphic effects).

NHDPlus: I continue to work as part of the NHDPlus team to improve NHDPlus and have shepherd and encouraged the use of NHDPlus-based SPARROW models throughout the Nation, as well as the development of high resolution NHDPlusHR for more detailed models

NHDPlus-based SPARROW modeling: I lead this effort by applying the NHDPlus-based SPARROW modeling to assess impacts on stream-water quality, as well as the impact on receiving waters such as lakes and estuaries throughout the Northeastern and Mid Atlantic regions of the United States.

Catchment Delineation Technique: I have applied our catchment delineation technique nationally, thus providing an important resource tool (topographically derived catchments) for watershed modelers throughout the Nation.

New England SPARROW: I used SPARROW to define loads to coastal waters and the relative importance of nutrient sources. I used the greater detail of the NHD and in doing so, demonstrated the usefulness of a major USGS mapping product, the NHD. I also developed techniques to use this product in conjunction with other national datasets. I have worked well with people from various State, regional, and Federal agencies, teaching workshops and sharing results.

NH Bedrock Aquifer Assessment: I developed (with Greg Schwarz) and applied a new statistical tool for ground-water prospecting in fractured-bedrock aquifers, and I demonstrated the benefits of bedrock geologic mapping. I enlisted experts in bedrock geologic mapping.

Stratified-drift Aquifer program: I led the way by incorporating geologic models, by computerizing the data and maps, and by developing numerical simulation techniques.
Core Science Systems: Science Analytics and Synthesis (SAS); Environmental Health: Toxic Substances Hydrology; Water Resources: Water Resources Availability Program; Water Resources: Water Observing Systems Program
https://ui.adsabs.harvard.edu/abs/2019AGUFMNS11C0645T/abstract 
Table 4.1. Summary of survey responses describing multidisciplinary projects.—Continued

[*Information in the table cells includes direct survey responses from individuals and have not been altered. Some abbreviations may reflect respondents understanding of commonly used abbreviations and some abbreviations are not defined. Due to the large list of abbreviations in this table, the abbreviations are listed at the beginning of this appendix.]

\begin{tabular}{|c|c|c|c|}
\hline Location & Integration disciplines & Skills & Capability \\
\hline Portland, Oregon & Climate, sediment & 1D and 2D hydraulic models & $\begin{array}{l}\text { Paleoflood hydrology, quantifying extreme riverine } \\
\text { floods, reducing uncertainty in flood-frequency } \\
\text { analyses, and investigating the link between climate } \\
\text { and extreme events. When not hunting for flood } \\
\text { deposits, Tess has been known to develop 1D and 2D } \\
\text { hydraulic models, map floodplain geomorphology, } \\
\text { dabble in sediment fingerprinting and examine trends } \\
\text { in streamflow. }\end{array}$ \\
\hline
\end{tabular}

Davie, Florida $\quad$ ECosystems $\quad$ MODLOW

Everglades biogeochemistry, invasive species detection and ecology, impacts of climate change, threatened and endangered species, ecosystem modeling, and monitoring water flow and quality; South Florida Information Access (SOFIA) data

\begin{tabular}{|c|c|c|c|}
\hline Urbana, Illinois & Ecosystems & $\begin{array}{l}\text { Surrogate Analysis and Index } \\
\text { Developer (SAID) tool }\end{array}$ & Fluvial egg drift simulator \\
\hline $\begin{array}{l}\text { Lexington, } \\
\text { Kentucky }\end{array}$ & Landscapes, land use & HSPF, APEX, HEC-HMS & $\begin{array}{l}\text { GLRI edge of field monitoring; impact of agricultural } \\
\text { conservation practices within small watersheds in the } \\
\text { Great Lakes Basin }\end{array}$ \\
\hline Boise, Idaho & Energy, health, ecosystems & $\begin{array}{l}\text { Reducing methylation using a CE- } \\
\text { QUAL-W2 model; real-time } \\
\text { sensors }\end{array}$ & $\begin{array}{l}\text { Stream mercury, bioaccumulation, methylation } \\
\text { reduction management; occurrence and toxicity } \\
\text { of organic contaminants in streams and streambed } \\
\text { sediment, microplastics, and using real-time sensors } \\
\text { to develop surrogate relations with water-quality } \\
\text { constituents such as nutrients, chloride, and fecal- } \\
\text { indicator bacteria. }\end{array}$ \\
\hline
\end{tabular}

\begin{tabular}{|c|c|c|c|}
\hline OR & Wildlife (beaver) & $\begin{array}{l}\text { Real-time surface-water, water- } \\
\text { quality, and groundwater dat }\end{array}$ & Beavers in Tualitin; hydrology, water quality, habitat \\
\hline $\begin{array}{l}\text { Sacramento, } \\
\text { California }\end{array}$ & Minerals, ecosystems, contaminants & $\begin{array}{l}\text { Environmental geochemistry } \\
\text { of metal contamination from } \\
\text { historical mining }\end{array}$ & $\begin{array}{l}\text { Abandoned mine lands mineral contaminants, water; } \\
\text { Iron Mtn California remediation; Mercury at Cache } \\
\text { Creek (water, fish, birds); reducing levels of MeHg } \\
\text { bioaccumulation in the Clear Lake food web; } \\
\text { Mitigation of mercury transport or bioaccumulation } \\
\text { downstream at Combie Reservoir, NEV }\end{array}$ \\
\hline
\end{tabular}


Have worked on multidisciplinary project with researchers from GMEG and the Fort Collins Science Center. I am not sure of the specific programs they were in.

Ecosystems: Environments; Ecosystems: Invasive Species; Ecosystems: Status \& Trends; Water Resources: Water Resources Availability Program; Water Resources: Water Observing Systems Program https://www.usgs.gov/ecosystems/environments-program/science/everglades?qt-science center objects $=0 \# q$ t-science_center_objects
Ecosystems: Invasive Species
Energy and Minerals: Mineral Resources; Environmental Health: Contaminant Biology; Environmental Health: Toxic Substances Hydrology
https://code.usgs.gov/FluEgg/fluegg

I was the modeling lead on the USGS GLRI EOF project where edge of field monitoring informed modeling decisions at the field and small watershed scales: https://wim.usgs.gov/ geonarrative/glri-eof/

EM Mineral Resources: collaboration with JoAnn Holloway on study of mercury contamination in a stream draining an abandoned mine site.

EH Contaminant Biology: I am the project manager of a 10-year federal/state/private cooperative study of mercury dynamics and bioaccumulation in the Snake River through the Hells Canyon Reservoir Complex. Primary study goals include determining the factors driving mercury methylation and testing management scenarios for reducing methylation using a CE-QUAL-W2 model. This study is a collaboration between Environmental Health (Collin Eagle-Smith, Dave Krabbenhoft, Mark Marvin-DiPasquale), the USGS Cooperative Program, the State of Idaho, Idaho Power Company, Portland State University, the University of Wisconsin at Madison, and Reed Harris Environmental.

https://www.usgs.gov/centers/or-water/science/city-beavers-tualatin-river-basin-beaverstudy?qt-science_center_objects=0\#qt-science_center_objects

https://www.usgs.gov/centers/ca-water/science/developingspatial-data-mineral-deposits-found-abandonedmine-lands;Ecosystems: Environments; Energy and Minerals: Mineral Resources; Environmental Health: Toxic Substances Hydrology; Water Resources: Water Resources Availability Program https://www.usgs.gov/centers/ca-water/science/developing-spatial-data-mineral-deposits-foundabandoned-mine-lands

Collaboration between CAWSC and MRP (GMEGSC)

https:/www.usgs.gov/centers/ca-water/science/iron-mountain-extraordinary-and-extremeenvironment

Collaboration between CAWSC and MRP (GGGSC)

https:/www.usgs.gov/centers/ca-water/science/determination-mercury-loads-cache-creeksettling-basin-inflow-and-outflows

https://www.usgs.gov/centers/ca-water/science/add-determination-mercury-loads-cache-creeksettling-basin-inflow-and

Collaboration between CAWSC, WMA (WRAP/ESPD), and Ecosystems (WERC)

https://www.usgs.gov/centers/ca-water/science/mercury-studies-sulphur-bank-mercury-mineand-clear-lake-california

Collaboration between CAWSC, WMA (WRAP/ESPD), WIWSC (NMRL), and Ecosystems (FRESC)

https://www.usgs.gov/centers/ca-water/science/monitoring-mercury-and-methylmercury-watersediment-and-biota-combie

Collaboration between CAWSC, WMA (WRAP/ESPD), and Ecosystems (FRESC)

Numerous other examples in completed projects. 
Table 4.1. Summary of survey responses describing multidisciplinary projects.-Continued

[*Information in the table cells includes direct survey responses from individuals and have not been altered. Some abbreviations may reflect respondents understanding of commonly used abbreviations and some abbreviations are not defined. Due to the large list of abbreviations in this table, the abbreviations are listed at the beginning of this appendix.]

\begin{tabular}{cccc}
\hline Location & Integration disciplines & Skills & Capability \\
\hline $\begin{array}{c}\text { Memphis, } \\
\text { Tennessee }\end{array}$ & Water use, geology, contaminants & Arsenic mapping & $\begin{array}{c}\text { Arsenic in aquifers; water withdrawals in Indiana; fault } \\
\text { mapping east Tennessee }\end{array}$
\end{tabular}

\begin{tabular}{cll}
\hline Carson City, & Wildlife, habitat & Contamination and pollution; \\
Nevada & Lake water quality; \\
& groundwater quality, \\
& pharmaceuticals
\end{tabular}

\begin{tabular}{|c|c|c|c|}
\hline $\begin{array}{l}\text { Ann Arbor, } \\
\text { Michigan }\end{array}$ & Coastal (beaches); Hazards (pathogens) & Beach science & Great Lakes, beach health, fisheries, water \\
\hline Tucson, Arizona & Landscapes & GIS Mapping, FGDC metadata & $\begin{array}{l}\text { GIS, water accounting, Colorado River, mapping tools } \\
\text { for brackish waters; land use/landcover, population } \\
\text { density, basin characterization, and creating FGDC- } \\
\text { compliant metadata }\end{array}$ \\
\hline Tucson, Arizona & Ecosystems, landscapes & Data management/collection & $\begin{array}{l}\text { Colorado River Delta monitoring and data management. } \\
\text { Colorado River Delta Restoration Minute } 323 \\
\text { Project. Multi-agency }\end{array}$ \\
\hline $\begin{array}{r}\text { Richmond, } \\
\text { Virginia }\end{array}$ & Water use, aquatic habitat & Chief, Decision Support Branch & $\begin{array}{l}\text { Tool to further examine nutrient and sediment trends; } \\
\text { Shenandoah River Accumulated Wastewater Ratio } \\
\text { Mapper; Integrated Assessment of Wastewater Reuse, } \\
\text { Exposure Risk, and Fish Endocrine Disruption in the } \\
\text { Shenandoah River Watershed }\end{array}$ \\
\hline
\end{tabular}




\section{USGS Collaboration}

Environmental Health: Toxic Substances Hydrology; Natural Hazards: Earthquake Hazards; Water Resources: Water Resources Availability Program;
I collaborate internationally and with United States Universities; Ecosystems: Energy and Wildlife; Ecosystems: Environments; Ecosystems: Invasive Species; Energy and Minerals: Mineral Resources; Energy and Minerals: Energy Resources; Water Resources: Water Resources Availability Program; Water Resources: Water Observing Systems Program; Water Resources: Integrated Water Prediction Program; Water Resources: Water Resources Research Act Program

Natural Hazards: Coastal \& Marine Hazards and Resources Program

\section{Relevant projects}

I worked with the Indiana Geological Survey as a Research Hydrogeologist on several projects funded through various state agencies. One project I worked on was to study arsenic in aquifers as a result of being hosted in glacial till. Another project studied tillage practices and studied volumetric water content of several sections of sediment (For this project I also did much grain size analysis for several hydrologic calculations). My main project consisted of mapping out and identifying significant water withdrawal facilities in Indiana. These are facilities that produced $>100,000$ gallons of surface and/or groundwater. These facilities are important because they influence local aquifers. This work was funded by the Indiana Department of Natural Resources. In addition to this water research I have conducted research identifying several faults in a new fault zone in east Tennessee we identify as the Daindridge vonore fault zone. I can have links to faulting research available upon request. https://igws.indiana.edu/staff/?user=ergamble

Hydrogeology projects I worked on:

https://igws.indiana.edu/research/ProjectSheet.cfm?sheet_ id $=312 \&$ type $=$ Researchers $\&$ IDNum $=5$

https://igws.indiana.edu/research/ProjectSheet.cfm?sheet_id=463\&type=Researchers\&IDN um $=27$

https://igws.indiana.edu/research/ProjectSheet.cfm?sheet_id=370

https://igws.indiana.edu/research/ProjectSheet.cfm?sheet_id=317

We are starting a new study at the Salton Sea on selenium hazard to the wildlife there. This includes starting an overall monitoring program and linking changes in hydrology to farming and natural inputs of Se to the lake. There is a considerable amount of data available and Earthmap might be a perfect way to communicate the results. It could also incorporate the structural, geothermal and faulting aspects into the project.
Beach health science across the Great Lakes, and application of advanced technologies in the Great Lakes.

Collaboration has been with agencies/NGOs/Universities inside and outside the USGS, with IBWC as foci of efforts with binational (Mexico/US) agencies.
Energy and Minerals: Mineral Resources; Land Resources: Land Change Science Program; Water Resources: Water Resources Availability Program; Water Resources: Water Resources Research Act Program

Ecosystems: Energy and Wildlife; Ecosystems: Fisheries; Environmental Health: Toxic Substances Hydrology
I am leading the USGS effort to develop a binational interdisciplinary data collection and management system for the Colorado River Delta Restoration Minute 323 Project. This includes coordinating with scientists and data collectors from multiple agencies, universities, and NGOs in two countries.

https://va.water.usgs.gov/webmap/shenmap/

https://pubs.acs.org/doi/abs/10.1021/acs.est.8b05655

This work continues within the Chesapeake Bay watershed as part of a collaboration between Ecosystems, Environmental Health and Water.

Ecoflows research and production of information products to describe the state of the science in a complex watershed with many management challenges:

https://doimspp.sharepoint.com/sites/GS-Chesapeake-Data

https://www.usgs.gov/centers/cba/science/usgs-develops-tool-further-examine-nutrient-andsediment-trends-chesapeake-bay?qt-science_center_objects=0\#qt-science_center_objects

Direct link to story map summarizing complex findings in the Chesapeake Bay watershed https://va.water.usgs.gov/storymap/NTN/

This featured collection represents collaborative work between USGS Water, FWS, University, and non-profit partners toward understanding endangered species' response to water quality or habitat degradation in rivers.

Funds were cooperative WSC, private, and from Ecosystems. Spanned two state WSC offices and state agencies that respond to the endangered species act or clean water act. The study area also crossed the boundary between regions for all federal partners: EPA, FWS, CORPs, adding additional complexity.

https://onlinelibrary.wiley.com/toc/17521688/2014/50/4 


\section{Table 4.1. Summary of survey responses describing multidisciplinary projects.-Continued}

[*Information in the table cells includes direct survey responses from individuals and have not been altered. Some abbreviations may reflect respondents understanding of commonly used abbreviations and some abbreviations are not defined. Due to the large list of abbreviations in this table, the abbreviations are listed at the beginning of this appendix.]

\begin{tabular}{|c|c|c|c|}
\hline Location & Integration disciplines & Skills & Capability \\
\hline \multicolumn{4}{|c|}{ Water (erosion and sedimentation) } \\
\hline $\begin{array}{l}\text { Flagstaff, } \\
\text { Arizona }\end{array}$ & Ecosystems (large rivers) & $\begin{array}{l}\text { Describe, quantify, and predict } \\
\text { geomorphic change }\end{array}$ & $\begin{array}{l}\text { Describe, quantify, and predict geomorphic change, } \\
\text { mostly on large rivers in the western United States; } \\
\text { sediment transport, the downstream effects of dams } \\
\text { and diversions, and the connections between physical } \\
\text { processes and ecological systems on large rivers. }\end{array}$ \\
\hline \multicolumn{4}{|c|}{ Water (fluvial geomorphology) } \\
\hline $\begin{array}{l}\text { Eureka, } \\
\text { California }\end{array}$ & $\begin{array}{l}\text { Remote sensing, Flora mapping, } \\
\text { sediment, climate }\end{array}$ & $\begin{array}{l}\text { Low altitude remote sensing } \\
\text { using small, unmanned aircraft } \\
\text { systems (sUAS), image } \\
\text { classification, change detection } \\
\text { using repeat geomorphic and } \\
\text { vegetation mapping, sediment } \\
\text { dynamics, and regional water } \\
\text { balance studies under historic } \\
\text { and future climates }\end{array}$ & $\begin{array}{l}\text { Managed flows in Klamath river are disturbing the } \\
\text { polchaete habitat and reducing the spread of } \\
\text { Ceratomyxa shasta. Spatially assess river corridor } \\
\text { conditions and the geomorphic effectiveness of } \\
\text { streamflow below Iron Gate Dam, and to relate the } \\
\text { flow history to scour and bed mobility conditions } \\
\text { necessary to manage fish disease. Establish sites } \\
\text { and methods for repeated monitoring and to develop } \\
\text { baseline datasets for interpreting future river response } \\
\text { to hydrologic disturbances including channel } \\
\text { maintenance flows for fish disease mitigation. } \\
\text { Assessing Suspended-Sediment Supply and Marsh } \\
\text { Accretion in Humboldt Bay, California. }\end{array}$ \\
\hline \multicolumn{4}{|c|}{ Water (groundwater contamination) } \\
\hline $\begin{array}{l}\text { Sacramento, } \\
\quad \text { California }\end{array}$ & Landscapes, human health, water use & $\begin{array}{l}\text { Co-production, Groundwater } \\
\text { contamination }\end{array}$ & $\begin{array}{l}\text { Groundwater contamination by oil development, } \\
\text { agriculture }\end{array}$ \\
\hline
\end{tabular}

Water (groundwater quality)

\begin{tabular}{|c|c|c|c|}
\hline $\begin{array}{l}\text { Mounds View, } \\
\text { Minnesota }\end{array}$ & Landscapes, hazards (oil) & $\begin{array}{l}\text { Innovative field tools for sample } \\
\text { collection and monitoring in } \\
\text { soil and shallow groundwater }\end{array}$ & $\begin{array}{l}\text { National Crude Oil Spill Fate and Natural Attenuation } \\
\text { Research Site; mobilization, transport, and fate } \\
\text { of crude oil in the shallow subsurface; microbial } \\
\text { processing; influences of land cover, contaminants, } \\
\text { and unsaturated zone properties on the quality and } \\
\text { quantity of water reaching unconfined aquifers }\end{array}$ \\
\hline
\end{tabular}

\begin{tabular}{|c|c|c|c|}
\hline \multicolumn{4}{|c|}{ Water (groundwater) } \\
\hline Tucson, Arizona & Geology, climate, energy mining & $\begin{array}{l}\text { Potential changes in groundwater } \\
\text { recharge under projected } \\
\text { climate change in the Colorado } \\
\text { River basin and understanding } \\
\text { the potential for uranium } \\
\text { mining effects on regional } \\
\text { water resources in the Grand } \\
\text { Canyon area. }\end{array}$ & $\begin{array}{l}\text { Uranium-bearing breccia pipe deposits to address } \\
\text { data gaps related to the potential effects of uranium } \\
\text { exploration and mining activities on the Grand } \\
\text { Canyon watershed, its people, wildlife, and water } \\
\text { resources. Study locations are primarily on Federal } \\
\text { lands with a few locations on Tribal lands and include } \\
\text { historic and active mines. }\end{array}$ \\
\hline $\begin{array}{c}\text { Carson City, } \\
\text { Nevada }\end{array}$ & Water (surface) & $\begin{array}{l}\text { Instrumentation for continuous } \\
\text { monitoring of subsurface } \\
\text { temperatures }\end{array}$ & $\begin{array}{l}\text { Biogeochemical processes at the sediment-water } \\
\text { interface and characterizing flow and transport in } \\
\text { hyporheic and groundwater systems using innovative } \\
\text { technologies and modeling }\end{array}$ \\
\hline
\end{tabular}

\begin{tabular}{lll}
\hline $\begin{array}{c}\text { Norcross, } \\
\text { Georgia }\end{array}$ & Water use & Water use compilation
\end{tabular}


Water (erosion and sedimentation)

I'm a physical scientist housed in the "ecosystems" mission area. Most of my interdisciplinary collaborations involve biologists also in ecosystems, or from other agencies like NPS. I don't know which boxes to check.

\section{Water (fluvial geomorphology)}

Core Science Systems: National Geospatial Program; Ecosystems: Environments; Ecosystems: Fisheries; Natural Hazards: Coastal \& Marine Hazards and Resources Program; Water Resources: Water Resources Availability Program https://www.usgs.gov/centers/ca-water/science/klamath-river-geomorphic-assessment?qtscience center objects $=0 \#$ qt-science center_objects

https://www.usgs.gov/centers/ca-water/science/assessing-suspended-sediment-supply-andmarsh-accretion-humboldt-bay-ca?qt-science_center_objects=0\#qt-science_center_objects

Water (groundwater contamination)

I have built several interdisciplinary and interorganizational teams both within the structures of the USGS and as part of an interagency program. See the latest example of a team that Matt Landon and I convened
Question \#8 needs to be expanded to include other agencies and organizations. It is key to understand USGS's niche in the science ecosystem to bring both the skills and resource manager partners together in a sustainable program. https://webapps.usgs.gov/cogg/;

\section{Water (groundwater quality)}

Environmental Health: Contaminant Biology; Environmental Health: Toxic Substances Hydrology; Water Resources: Water Resources Availability Program
https://doimspp.sharepoint.com/sites/GS-EHMAEnergyTeam?CT=1584650394735\&OR=OWANT\&CID=26d7c778-1325-fbeb-dc41-e513b55d9b0f

https://www.sciencebase.gov/catalog/item/5910d9b2e4b0e541a03ac976?community=National+ Crude + Oil + Spill+Fate+and + Natural+Attenuation+Research + Site

https://mn.water.usgs.gov/projects/bemidji/
Energy and Minerals: Mineral Resources; Environmental Health: Contaminant Biology; Environmental Health: Toxic Substances Hydrology

\section{Water (groundwater)}

https://webapps.usgs.gov/uraniummine/
Ecosystems: Environments

Water Resources: Water Resources Availability Program
As a research scientist at a water science center, there is very limited opportunities to integrate research with other interdisciplinary mission areas. For example, every four years (not frequent enough) there is a gw workshop for scientists doing work in water to come together and share research. When will we have a workshop at the scale of AGU that will integrate all interdisciplinary fields within the USGS to build relationships and network? 
Table 4.1. Summary of survey responses describing multidisciplinary projects.—Continued

[*Information in the table cells includes direct survey responses from individuals and have not been altered. Some abbreviations may reflect respondents understanding of commonly used abbreviations and some abbreviations are not defined. Due to the large list of abbreviations in this table, the abbreviations are listed at the beginning of this appendix.]

\begin{tabular}{|c|c|c|c|}
\hline Location & Integration disciplines & Skills & Capability \\
\hline \multicolumn{4}{|c|}{ Water (hydrodynamics) } \\
\hline Urbana, Illinois & $\begin{array}{l}\text { Ecosystems (aquatic), water quality, } \\
\text { wildlife (fish) }\end{array}$ & $\begin{array}{l}\text { Autonomous underwater vehicle } \\
\text { (AUV) paired with traditional } \\
\text { manned-boat instrument } \\
\text { platforms for high-resolution, } \\
\text { integrated synoptic surveys } \\
\text { of water-quality distributions, } \\
\text { bathymetry, and velocity }\end{array}$ & $\begin{array}{l}\text { Underwater sound technology is being field tested as a } \\
\text { tool for herding and deterring Bighead carp, and is } \\
\text { being used in combination with fish netting activities } \\
\text { to maximize control efforts; hydrodynamics in } \\
\text { driving water-quality distributions and ecological } \\
\text { processes }\end{array}$ \\
\hline \multicolumn{4}{|c|}{ Water (hydrology) } \\
\hline $\begin{array}{l}\text { Downingtown, } \\
\text { Pennsylvania }\end{array}$ & Water quality & Field Instrumentation & $\begin{array}{l}\text { Water quality, measurement technology, Delaware River } \\
\text { Basin }\end{array}$ \\
\hline
\end{tabular}

\begin{tabular}{|c|c|c|c|}
\hline & Coastal hazards, Earth surface geology & $\begin{array}{l}\text { Short-term changes in land } \\
\text { subsidence due to human } \\
\text { activities }\end{array}$ & $\begin{array}{l}\text { Land Subsidence and Sea-Level Rise in the Chesapeake } \\
\text { Bay; isolate short-term changes in land subsidence } \\
\text { due to human activities, from long-term geologic } \\
\text { signals due to glacial cycles and deep Earth } \\
\text { processes; Appalachian Plateaus Groundwater } \\
\text { Availability Study }\end{array}$ \\
\hline \multicolumn{4}{|c|}{ Water (Quality) } \\
\hline $\begin{array}{l}\text { Norcross, } \\
\text { Georgia }\end{array}$ & Groundwater, water use & Groundwater mapping & Mapping groundwater conditions in Georgia \\
\hline $\begin{array}{l}\text { Baltimore, } \\
\text { Maryland }\end{array}$ & Landscapes & SPARROW model, & SPARROW interpretation, synthesis \\
\hline $\begin{array}{l}\text { Sacramento, } \\
\text { California }\end{array}$ & Ecosystems (aquatic vegetation) & Invasive plants & $\begin{array}{l}\text { Invasive aquatic vegetation in the Sacramento-San } \\
\text { Joaquin Delta; reductions dissolved inorganic } \\
\text { nitrogen levels (specifically loads of ammonium), due } \\
\text { to an upgrade to Sacramento's Regional Wastewater } \\
\text { Treatment Plant, will affect phytoplankton versus IAV } \\
\text { production; Delta SCHISM modeling effort, the only } \\
\text { modeling effort in the region that accounts for the } \\
\text { growth and decay of IAV }\end{array}$ \\
\hline $\begin{array}{l}\text { Coram, New } \\
\text { York }\end{array}$ & Hazards, SCORR & Microplastics, oil spills in rivers & $\begin{array}{l}\text { Microplastics in northeastern rivers. Oil spill decision } \\
\text { support tool- SCORR design; hydrology and } \\
\text { contaminants of hurricane events }\end{array}$ \\
\hline
\end{tabular}

\begin{tabular}{ccc}
\hline $\begin{array}{l}\text { Lansing, } \\
\text { Michigan }\end{array}$ & Fcotoxicology & Factors affecting algal production \\
& to study factors driving algal toxin production, how \\
& and where wildlife or humans are exposed to toxins, \\
& and ecotoxicology; Lake Michigan Coastal/Nearshore \\
Ecosystems, With Application to Lake Michigan & Lakewide Management Plan (LaMP)
\end{tabular}

\begin{tabular}{lll}
\hline $\begin{array}{c}\text { East Hartford, } \\
\text { Connecticut }\end{array}$ & Geology, ecosystems & Nutrient budgets for rivers
\end{tabular}


Water Resources: Water Observing Systems Program Mapping Program; Ecosystems: Environments

\section{Water (hydrology)}

Developed multiple proposals for NGWOS; including salinity mapping/improvements and the White Clay Creek sediment proposal, which was funded. Originally the WCC proposal was an attempt to integrate between NGWOS/IWAAs/and IWP, but funding has been difficult to secure. I see the potential to include additional assets (Ecosystems/Land resources) to further refine our understanding of the complete system.

https://www.usgs.gov/centers/cba/science/new-crowd-sourcing-will-contribute-study-landsubsidence-and-sea-level-rise?qt-science_center_objects=0\#qt-science_center_objects

https://va.water.usgs.gov/appalachianplateaus/main.html

\section{Water (Quality)}

Core Science Systems: National Geologic and Geophysical Data Preservation Program; Core Science Systems: National Geospatial Program; Water Resources: Water Resources Availability Program; Water Resources: Water Observing Systems Program

National Water-Quality Program; Ecosystems: Environments

Outside of USGS and USDOI - California Department of Water Resources, California Department of Fish and Wildlife, California Maritime Academy, San Francisco State University, UC Davis, San Francisco Estuary Institute, Virginia Institute of Marine Science
https://www.google.com/search?q=groundwater+conditions+in+georgia\&rlz=1C1GCEA_enUS 768US768\&oq=gr\&aqs =chrome.3.69i57j69i5913j69i60j69i6112.4718j0j7\&sourceid=chrome $\& \mathrm{ie}=\mathrm{UTF}-8$

One result of collaboration across Mission Areas: https://doi.org/10.1111/1752-1688.12756

https://www.usgs.gov/centers/ca-water/science/effects-aquatic-vegetation-water-quality-andresidence-time-bay-delta?qt-science_center_objects=0\#qt-science_center_objects

https://www.usgs.gov/centers/ca-water/science/modeling-nitrogen-reduction-benefit-invasiveaquatic-vegetation-vs-native?qt-science_center_objects=0\#qt-science_center_objects
Environmental Health: Toxic Substances Hydrology; Water Resources: Water Observing Systems Program
Developed proposal for funding to bring microplastics capability to the Northeast Region: https://www.usgs.gov/centers/md-de-dc-water/science/microplastics-urban-streams-northeastregion;

Helped develop decision support tool for regional assessment before/after storms and expanded on this to inland applications (e.g., oil spills) and include colleagues throughout the Region https://toxics.usgs.gov/scorr/;

Several studies related to Hurricane Sandy response

Ecosystems: Environments; Ecosystems: Status \& Trends; Ecosystems: Wildlife Disease; Environmental Health: Contaminant Biology; Environmental Health: Toxic Substances Hydrology; Water Resources: Water Resources Availability Program

Work with staff who used to be in Geologic Discipline, wherever that is now
Co-lead for Environmental Health Toxin project- integrates across several Water and Ecosystem programs: https://www.usgs.gov/mission-areas/environmental-health/science/toxins-andharmful-algal-blooms-science-team?qt-science_center_objects=0\#qt-science_center_objects Worked with Ecosystems and Water Centers on Great Lakes Coastal multidisciplinary studies: https://pubs.usgs.gov/of/2013/1138/

Lead for Great Lakes Restoration Initiative HABs projects which crosses Ecosystem and Water programs and Centers.

We more frequently work cross discipline with cooperating agencies, and I do this frequently with staff from Universities, and cooperating agencies funding our work. We are typically not funded to do work with any of the other mission areas. 
Table 4.1. Summary of survey responses describing multidisciplinary projects.—Continued

[*Information in the table cells includes direct survey responses from individuals and have not been altered. Some abbreviations may reflect respondents understanding of commonly used abbreviations and some abbreviations are not defined. Due to the large list of abbreviations in this table, the abbreviations are listed at the beginning of this appendix.]

\begin{tabular}{|c|c|c|c|}
\hline Location & Integration disciplines & Skills & Capability \\
\hline \multicolumn{4}{|c|}{ Water (qw modeling) } \\
\hline $\begin{array}{l}\text { Lakewood, } \\
\text { Colorado }\end{array}$ & Landscapes, subsurface geology & $\begin{array}{l}\text { Reaction-Transport Modeling in } \\
\text { Groundwater and Watershed } \\
\text { Systems }\end{array}$ & $\begin{array}{l}\text { Processes driving water and solutes through watersheds } \\
\text { from the continental divide to tropical rain forests. } \\
\text { Current projects include Reaction-Transport } \\
\text { Modeling in Groundwater and Watershed Systems }\end{array}$ \\
\hline $\begin{array}{l}\text { Lakewood, } \\
\text { Colorado }\end{array}$ & Ecosystems, landscapes & Watershed modeling & $\begin{array}{l}\text { 1. Improve understanding of watershed system } \\
\text { dynamics } 2 \text {. Develop computer models to simulate } \\
\text { and evaluate the effects of various combinations of } \\
\text { precipitation, climate, and land use on streamflow and } \\
\text { other hydrologic components } 3 \text {. Develop procedures } \\
\text { and techniques to estimate model parameters by using } \\
\text { measurable watershed and climatic characteristics. }\end{array}$ \\
\hline \multicolumn{4}{|c|}{ Water (sediment) } \\
\hline $\begin{array}{l}\text { West Valley City, } \\
\text { Utah }\end{array}$ & Landscapes, geospatial analysis & $\begin{array}{l}\text { geospatial analysis, surface } \\
\text { water (non-marine), runoff, } \\
\text { topography, spatial analysis }\end{array}$ & $\begin{array}{l}\text { SCORR; Geospatial analysis; source-sink and } \\
\text { cause-effect relationships between contaminants } \\
\text { and vulnerable communities; Lidar and mapping } \\
\text { suburbanization; Endocrine disruption in Ches Bay }\end{array}$ \\
\hline
\end{tabular}

\begin{tabular}{llcc}
\hline $\begin{array}{l}\text { Flagstaff, } \\
\text { Arizona }\end{array}$ & Water quality & $\begin{array}{c}\text { Methods for making continuous } \\
\text { measurements of suspended- } \\
\text { sediment transport and grain } \\
\text { size in rivers }\end{array}$ & $\begin{array}{c}\text { Grand Canyon Monitoring and Research Center } \\
\text { Discharge, Sediment, and Water Quality Monitoring. } \\
\text { sediment transport and sedimentology, and the } \\
\text { physics linking sediment transport, sediment grain } \\
\text { size, and channel morphology in rivers }\end{array}$ \\
\hline Portland, Oregon & Landscapes, wildlife (amphibians) & $\begin{array}{c}\text { Real-time concentrations of } \\
\text { suspended sediment and other } \\
\text { constituents in water }\end{array}$ & $\begin{array}{c}\text { Effects of land and water management on aquatic } \\
\text { resources; primarily water quality, sediment, and } \\
\text { ecosystem responses, ARMI }\end{array}$
\end{tabular}

Water (urban hydrology)

\begin{tabular}{|c|c|c|c|}
\hline Urbana, Illinois & Wildlife (fisheries) & Hydroacoustic data collection & $\begin{array}{l}\text { Asian carp; urban hydraulics and hydrology throughout } \\
\text { the Chicago area; and utilized our experience in } \\
\text { hydroacoustic data collection }\end{array}$ \\
\hline \multicolumn{4}{|c|}{ Water (water quality) } \\
\hline \multirow[t]{2}{*}{$\begin{array}{l}\text { Albuquerque, } \\
\text { New Mexico }\end{array}$} & Wildlife (fish), landscapes & Water quality trends & $\begin{array}{l}\text { Bull trout telemetry and habitat in Boise River; urban } \\
\text { water quality and urban surface-water modeling. His } \\
\text { current research also now includes water quality trend } \\
\text { analysis in the Rio Grande River }\end{array}$ \\
\hline & & Water (water use) & \\
\hline \multirow[t]{2}{*}{$\begin{array}{l}\text { Middleton, } \\
\text { Wisconsin }\end{array}$} & Data management, geology, & $\begin{array}{l}\text { USGS' Site-Specific Water-Use } \\
\text { Database (SWUDS) }\end{array}$ & $\begin{array}{l}\text { Water Budget Estimation and Evaluation Project } \\
\text { (WBEEP) }\end{array}$ \\
\hline & & ater (watershed biogeochemistry) & \\
\hline Troy, New York & Ecosystems (forests, soils), climate & $\begin{array}{l}\text { Integration science, multi-scale, } \\
\text { interdisciplinary networks }\end{array}$ & $\begin{array}{l}\text { Watershed biogeochemistry; multi-scale network design, } \\
\text { developing interdisciplinary investigations }\end{array}$ \\
\hline
\end{tabular}




USGS Collaboration
Ecosystems: Environments; Ecosystems: Status \& Trends;
Natural Hazards: Coastal \& Marine Hazards and
Resources Program
Ecosystems: Status \& Trends; Environmental Health: Toxic
Substances Hydrology; Water Resources: Integrated
Water Prediction Program

\section{Water (qw modeling)}

https://water.usgs.gov/webb/

https://pubs.er.usgs.gov/publication/tm6B35

https://www.usgs.gov/staff-profiles/richard-webb?qt-staff_profile_science_products=0\#qt-staff_ profile_science_products

Water Prediction Program

armi.usgs.gov
https://wwwbrr.cr.usgs.gov/projects/SW_MoWS/

https://wwwbrr.cr.usgs.gov/projects/SW_MoWS/

\section{Water (sediment)}

Ecosystems: Fish \& Wildlife Disease; Environmental Health: Contaminant Biology; Environmental Health: Toxic Substances Hydrology; Land Resources: Land Change Science Program; Natural Hazards: Emergency Management
Environmental Health: https://www.usgs.gov/mission-areas/environmental-health/science/ geospatial-analyses-and-applications-salt-lake-city-utah?qt-science_center_objects=0\#qtscience_center_objects

Land Change Science Program: https://doi.org/10.1016/j.geomorph.2014.04.038

Emergency Management: https://toxics.usgs.gov/scorr/

Fish and Wildlife Disease: https://www.usgs.gov/mission-areas/environmental-health/ science/endocrine-disrupting-compounds-chesapeake-bay-watershed?qt-science_center_ objects=0\#qt-science_center_objects

https://www.gcmrc.gov/discharge_qw_sediment/

See extended answer to question 7 above.
Core Science Systems: National Geospatial Program; Ecosystems: Energy and Wildlife; Ecosystems: Environments; Ecosystems: Fish \& Wildlife Disease; Ecosystems: Wildlife Disease; Environmental Health: Toxic Substances Hydrology; Water Resources: Water Resources Availability Program; Water Resources: Water Observing Systems Program; Water Resources: Integrated Water Prediction Program

\section{Water (urban hydrology)}

Ecosystems: Invasive Species; Water Resources: Water Observing Systems Program; Water Resources: Water Resources Research Act Program

The whole topic is vague and I have no idea what you're fishing for.

Water (water quality)

Ecosystems: Fisheries
I have worked on multiple Asian carp projects between Ecosystems (Invasive Species) and the Water Science Centers

https://pubs.er.usgs.gov/publication/ds1042

\section{Water (water use)}

Water Resources: Water Resources Availability Program

https://doimspp.sharepoint.com/sites/WBEEP/SitePages/Home.aspx

Water (watershed biogeochemistry)

Ecosystems: Energy and Wildlife; Ecosystems: Status \& Trends; Energy and Minerals: Science $\&$ Decisions Center; Natural Hazards: Coastal \& Marine Hazards and Resources Program; Water Resources: Integrated Water Prediction Program
I lead or participated in several interagency, multi-mission efforts at the USDOI and/or USGS to address coastal resilience metrics after Hurricane Sandy, the effects of hydraulic fracturing for gas in the Appalachian Basin, development of an Ecosystem Mission Landscapes program, a NAAR Urban/Coastal Resilience Initiative, and the effects of climate change on terrestrial and aquatic systems. 
Table 4.1. Summary of survey responses describing multidisciplinary projects.—Continued

[*Information in the table cells includes direct survey responses from individuals and have not been altered. Some abbreviations may reflect respondents understanding of commonly used abbreviations and some abbreviations are not defined. Due to the large list of abbreviations in this table, the abbreviations are listed at the beginning of this appendix.]

\begin{tabular}{cccc}
\hline Location & Integration disciplines & Skills & Capability \\
\hline Tucson, Arizona & $\begin{array}{c}\text { Water availability, groundwater systems, } \\
\text { climate forcing }\end{array}$ & $\begin{array}{c}\text { Climate Models, Hydrology } \\
\text { models }\end{array}$ & $\begin{array}{l}\text { Colorado Mountains Regional GW; IWAAs; Integrated } \\
\text { Water Availability Assessments; modeling and } \\
\text { statistical approaches to develop physically } \\
\text { based understanding of how climatic forcings are } \\
\text { damped or amplified through feedback processes in } \\
\text { hydrologic systems }\end{array}$ \\
\hline
\end{tabular}

\section{Water use}

\begin{tabular}{ll}
\hline $\begin{array}{c}\text { Flagstaff, } \\
\text { Arizona }\end{array}$ & Ecosystems (flora), water (drought), \\
High resolution global cropland \\
data
\end{tabular}

GFSAD30 is a NASA funded project to provide high resolution global cropland data and their water use that contributes towards global food security; Global Hyperspectral Imaging Spectroscopy of AgriculturalCrops \& Vegetation (GHISA); Two goals of waterSMART are to 1) establish water availability and its use based on an understanding of the past and present water users and to 2) project water availability and use scenarios into the future taking into consideration climate variability and change

\begin{tabular}{llll}
\hline Tucson, Arizona & Landscapes & Wabitat Modeling & Desert tortoise habitat, MRLC \\
\hline $\begin{array}{c}\text { Fort Collins, } \\
\text { Colorado }\end{array}$ & Climate, wetland hydrology & $\begin{array}{c}\text { Modeling resource dynamics and } \\
\text { management scenarios }\end{array}$ & $\begin{array}{c}\text { Climate, NC coast, adaptation in refuges; quantitative } \\
\text { modeling to understand resource dynamics and use } \\
\text { of decision-theoretic methods to guide management } \\
\text { decisions under uncertainty }\end{array}$ \\
\hline $\begin{array}{c}\text { Corvallis, } \\
\text { Oregon }\end{array}$ & Water, hazards & Leader of ARMI & ARMI
\end{tabular}

\begin{tabular}{|c|c|c|c|}
\hline \multicolumn{4}{|c|}{ Wildlife (amphibians) } \\
\hline $\begin{array}{l}\text { Norcross, } \\
\text { Georgia }\end{array}$ & Water, genetics, & eDNA surveys & $\begin{array}{l}\text { Environmental DNA for detecting species of interest; } \\
\text { amphibians }\end{array}$ \\
\hline \multicolumn{4}{|c|}{ Wildlife (bats) } \\
\hline $\begin{array}{l}\text { Fort Collins, } \\
\quad \text { Colorado }\end{array}$ & Landscapes (land use), habitat & $\begin{array}{l}\text { Field methodologies and } \\
\text { statistical modeling }\end{array}$ & North American Bat Monitoring \\
\hline \multicolumn{4}{|c|}{ Wildlife (birds) } \\
\hline Laurel, Maryland & Urbanization & Bird banding data, communication & Birds, urbanization, and community science. \\
\hline $\begin{array}{l}\text { Cook, } \\
\text { Washington }\end{array}$ & Water, habitat & SWFL Habitat Viewer & $\begin{array}{l}\text { Bird breeding habitat, insect stressors, The SWFL } \\
\text { Habitat Viewer; current and future distributions of } \\
\text { common, threatened, and endangered species. I have } \\
\text { developed habitat models across the western U.S. for } \\
\text { fish, birds, mammals, and reptiles. Climate-change, } \\
\text { ecological flows, and riparian obligates are my focal } \\
\text { areas. }\end{array}$ \\
\hline
\end{tabular}


USGS Collaboration

\section{Relevant projects}

\section{Water modeling}

Core Science Systems: National Cooperative Geologic Mapping Program; Ecosystems: Environments; Water Resources: Water Resources Availability Program; Water Resources: Integrated Water Prediction Program; Water Resources: Water Resources Research Act Program https://www.usgs.gov/centers/az-water/science/colorado-plateaus-regional-groundwateravailability?qt-science_center_objects=0\#qt-science_center_objects.

https://www.usgs.gov/mission-areas/water-resources/science/integrated-water-availabilityassessments-using-cooperative?qt-science_center_objects $=0 \# q t-s c i e n c e$ _enter_objects

\section{Water use}

www.usgs.gov/wgsc/gfsad30

www.usgs.gov/WGSC/GHISA

www.usgs.gov/WGSC/GCWP
Change Science Program; Land Resources: National Land Imaging Program; Water Resources: Water Resources Availability Program

\section{Wildlife}

https://pubs.usgs.gov/of/2009/1102/ofr20091102.pdf

https://www.mrlc.gov/

https://cascprojects.org/\#/project/4f8c6557e4b0546c0c397b4c/553fddf0e4b0a658d7938ef5
Ecosystems: Environments; Ecosystems: Fish \& Wildlife Disease; Ecosystems: Invasive Species; Ecosystems: Wildlife Disease; Environmental Health: Contaminant Biology
I didn't check the boxes because I don't know the names of the specific units but I'm in EMA and work extensively with WMA and EH. I've spent time scoping possible collaboration with Hazards (SHIRA?) and have coordinated with Core Sciences to some extent. I lead a 20 year collaboration between EMA, WMA, and EH: armi.usgs.gov

$$
\text { Wildlife (amphibians) }
$$

Environmental Health: Toxic Substances Hydrology

\section{Wildlife (bats)}

Ecosystems: Energy and Wildlife; Ecosystems: Fish \& Wildlife Disease; Ecosystems: Status and Trends; Ecosystems: Wildlife Disease

Core Science Systems: Science Analytics and Synthesis (SAS); Ecosystems: Energy and Wildlife

Ecosystems: Environments; Ecosystems: Fisheries

\section{Wildlife (birds)}

\section{STEP-UP}

https://sciencebase.usgs.gov/nabat/\#/home

For planning and management purposes, agencies require a web application that can locate, map, and monitor Southwestern Willow Flycatcher (SWFL) breeding habitat across its range. The SWFL Habitat Viewer can identify potential flycatcher habitat and monitor changes caused by stressors, such as beetles, fire, or drought.

Website: https://www.usgs.gov/centers/wfrc/science/southwestern-willow-flycatcher-habitatviewer?qt-science_center_objects $=0 \#$ \#t-science_center_objects

The SWFL Habitat Viewer was developed to meet the needs of organizations by providing maps of predicted flycatcher breeding habitat throughout its range. Maps are provided from 2013 to present and cover 57 satellite scenes. Maps identify predicted flycatcher habitat based upon the amount of green vegetation within a 120 -m radius of each cell, and the size of floodplain within a $360-\mathrm{m}$ radius.

Web mapping application: https://usgs.maps.arcgis.com/apps/webappviewer/index.html?id=0fea $104260 \mathrm{ef} 465 \mathrm{fbd} 53 \mathrm{~b} 69 \mathrm{~b} 25 \mathrm{a} 2 \mathrm{a} 5 \mathrm{f} 9$ 
Table 4.1. Summary of survey responses describing multidisciplinary projects.—Continued

[*Information in the table cells includes direct survey responses from individuals and have not been altered. Some abbreviations may reflect respondents understanding of commonly used abbreviations and some abbreviations are not defined. Due to the large list of abbreviations in this table, the abbreviations are listed at the beginning of this appendix.]

\begin{tabular}{cccc}
\hline Location & \multicolumn{1}{c}{ Integration disciplines } & Skills & Capability \\
\hline Laurel, Maryland & Water, disease & Avian influenza &
\end{tabular}

\begin{tabular}{llll}
\hline & Wildlife (disease) & \\
\hline $\begin{array}{l}\text { Madison, } \\
\text { Wisconsin }\end{array}$ & Ecosystems & Decision support tools & Branch Chief; Ecology and Epidemiology, NWHC
\end{tabular}

\section{Wildlife (fisheries)}

\begin{tabular}{llcl}
\hline Athens, Georgia & Water, geography & Restoration best practice & $\begin{array}{c}\text { ACF basin focal area, Flint River geography and } \\
\text { geology }\end{array}$
\end{tabular}

Cook,
$\begin{gathered}\text { Water, genetics, contaminants, aquatic } \\ \text { Washington }\end{gathered}$

Washington ecosystems
Development of long-term integrated monitoring programs; invasives
Columbia River contaminants, eDNA, endocrine disruptors, water sediment, human and wildlife health

\begin{tabular}{|c|c|c|}
\hline $\begin{array}{c}\text { Leetown, West } \\
\text { Virginia }\end{array}$ & Water (quality), hazards, & $\begin{array}{l}\text { Multiple scales, employing a } \\
\text { combination of field surveys, } \\
\text { statistical analyses, computer } \\
\text { simulations and meta-analyses. }\end{array}$ \\
\hline
\end{tabular}

Leetown, West Water (quality), hazards, simulations and meta-analyses.

Wildlife (herbivores)

\begin{tabular}{llcc} 
& & Wildlife (herbivores) & and meta-analyses. \\
\hline $\begin{array}{c}\text { Fort Collins, } \\
\text { Colorado }\end{array}$ & Ecosystems, landscapes, genetics & Herd management & Tick diseases, ecology \\
\hline $\begin{array}{l}\text { Kingston, Rhode } \\
\text { Island }\end{array}$ & Landscapes, climate, pathogens & Tick ecology & Wildlife disease \\
\hline $\begin{array}{l}\text { Madison, } \\
\text { Wisconsin }\end{array}$ & Landscapes & Wildlife mortality information & Wildlife health information sharing partnership; Wildlife \\
Disease Specialist
\end{tabular}

1) Ecological flow requirements of aquatic systems, and 2) effects of anthropogenic activities on aquatic ecosystem structure and function. Within each focal area he conducts research to answer questions at multiple scales, employing a combination of field surveys, statistical analyses, computer simulations and meta-analyses. 
USGS Collaboration

Not sure which Water Resources Program: MD, DE, VA, DC Water Science Center; Core Science Systems: Science Analytics and Synthesis (SAS); Ecosystems: Energy and Wildlife; Ecosystems: Environments; Ecosystems: Fish and Wildlife Disease; Ecosystems: Status \& Trends; Ecosystems: Wildlife Disease; Environmental Health: Contaminant Biology; Environmental Health: Toxic Substances Hydrology

Ecosystems: Fish \& Wildlife Disease; Ecosystems: Invasive Species; Ecosystems: Status \& Trends; Ecosystems: Wildlife Disease; Environmental Health: Contaminant Biology

Core Science Systems: Science Analytics and Synthesis (SAS); Ecosystems: Fisheries; Ecosystems: Invasive Species; Ecosystems: Status \& Trends; Environmental Health: Contaminant Biology; Environmental Health: Toxic Substances Hydrology; Natural Hazards: Coastal \& Marine Hazards and Resources Program

Core Science Systems: National Geospatial Program; Core Science Systems: Science Analytics and Synthesis (SAS); Ecosystems: Environments; Ecosystems:

Fisheries; Environmental Health: Toxic Substances Hydrology

\section{Wildlife (disease)}

As the Ecology and Epidemiology Branch Chief at NWHC, I manage WHISPers development and utilization, internal case management, our epidemiology service (for connecting stakeholders with experts to guide investigations of wildlife mortality), and quantitative modeling, forecasting, and app development.

Wildlife (fisheries)

Several efforts" EMA, WMA and Geography and Geology - "Flint River Science Thrust" (early 2000's); EMA and WMA- Southeast Regional Assessment Project ( 2010); EMA and WMA: WaterSmart Focal Area Study: ACF Basin and Coastal Carolina Focal Area Study; others

https://www.usgs.gov/centers/or-water/science/columbia-river-contaminants-and-habitatcharacterization-study?qt-science_center_objects $=0 \#$ qt-science_center_objects

A few projects that I have worked on that involved multiple MAs: Delaware WaterSMART project, Unconventional Oil and Gas, and currently the USGS Chesapeake Bay Studies

Wildlife (herbivores)

Ecosystems: Energy and Wildlife; Ecosystems Environments

Ecosystems: Wildlife Disease
I only work within Ecosystems

Wildlife (ticks) Ecosystems

Most of my collaborators have been outside of the USGS (e.g., university scientists, scientists from other federal agencies).

Wildlife disease

https://whispers.usgs.gov
Ecosystems: Fish \& Wildlife Disease; Ecosystems: Wildlife Disease

\section{Relevant projects}

also have multidisciplinary efforts outside of USGS including United Nations Food and Agriculture Organization, USDA, international research agencies, and universities 


\section{Appendix 5. Methods and Techniques for Dynamically Assembling Scientific Capacity Data}

Information about U.S. Geological Survey (USGS) products, people, organizational units, projects, and other aspects of describing USGS work is scattered across several internal and external systems and tools and projected out into online registries such as the Digital Object Identifier and the Open Researcher and Contributor ID (ORCID) systems. As part of the Earth Monitoring, Analysis, and Prediction (EarthMAP) Capacity Assessment project, we initiated an experiment into how this breadth of information could be queried dynamically, assembled for analysis, and used in assessing scientific capacity. The goal of the proof-of-concept was to demonstrate how and where software can serve as a broker across multiple, disparate data sources, the potential value of the content from those sources, and identify gaps in accessibility, interoperability, and reusability of current online sources.

The USGS has attempted to develop this kind of assessment capability several times in recent history, most notably with a technological system developed in the late 2000s called the Geospatial Management Information System (GMIS; Helterbrand and Sieverling, 2008). These efforts have attempted to pull together information about people and organizations, projects, publications (or "creative works"), datasets, and other assets but have run into the challenge that these types of information are not coherently and consistently described. Data are scattered across multiple information systems and databases, only some of which are reasonably accessible through some type of interface. Attempts at developing a new system or making large changes to existing systems have been met with various logistical challenges that have impeded progress.

The Capacity Assessment Team explored a new way of thinking about this problem that tries to make the best use of any available information, with a focus on people, organizations, publications, datasets, and models as that information currently exists, along with the abstract characteristics of associated expertise and subject matters (referred to collectively as "entities" in our conceptual model). We used public sources and registries, focusing on the substance of the information content and the relationships we could establish between entities. We focused on public information that is available to anyone on the web, partly to avoid the challenge of determining permissions of viewing proprietary information but also to probe what is already available online for anyone to assemble and better characterize our organization. We also embrace a degree of uncertainty in our conceptual model by referring to the relationships between entities as claims or assertions, qualifying each relationship with a date and reference source (Uniform Resource Locator, URL) so that we can better understand where and when each relationship was asserted to help determine usability.
The basic design pattern used was that of a knowledge graph or linked open data, focusing more on the relationships and linkability between entities and summarizing to a very small number of descriptive properties about each entity. We chose to highlight certain things that were found in source information as properties about entities like people (for example, job title and terms describing expertise) as nodes/ entities in the graph to help expose the important linkages between entities. We also focused on the linked open-data model to help highlight a technique that could be employed where current artifacts like the web pages that advertise our products, projects, organizational units, and people could be marked up with structured metadata for software access, search engine optimization, and other benefits (schema.org).

The software codes that execute data processing and graph building operations are part of an ongoing development effort available as provisional software on GitHub (https://github.com/). The underlying Python package, called pylinkedemd, contains modules that carry out data retrieval and transformation functions. We codenamed the experimental proof-of-concept effort Integrated Science Assessment Information Database (iSAID). The experimental design and workflows for gathering data and building the knowledge graph are contained in a set of Jupyter Notebooks (https://jupyter.org/) that are part of the code repository. This is a continuing project that has not been released yet.

In building the data model, three overarching categories of information that are critical to conducting effective capacity assessment were identified: (1) People and Organizations, (2) Creative Works, and (3) Open Science Assets. Information about people in the USGS is perhaps the most fundamental and critical element of master data. These data are where the iSAID proof-of-concept focused most of its attention. Related to people, organizational units provide a grouping mechanism and set of identified entities that are important in characterizing capabilities and assessing capacity. Creative works are published and released products of various kinds that characterize the bulk of the accomplishment of our mission. From a capacity assessment standpoint, creative works provide direct evidence of our capabilities as an institution and the intellectual contributions of the people within the institution. People, organizations, and creative works often represent only part of the capabilities and tools that are essential for manifesting the EarthMAP vision. Open Science Assets are those less structured units of information content such as labs and other types of scientific facilities (for example, research vessels), deployed instrument platforms (for example, satellites, stream gages), and computation facilities. These entities usually represent numerous capabilities for observation and measurement, data analysis, and other elements of operational science. 
Table 5.1. List of information sources used in the iSAID proof-of-concept.

[Abbreviations: USGS, U.S. Geological Survey; DOI, digital object identifier]

\begin{tabular}{lcc}
\hline \multicolumn{1}{c}{ Information source } & Entities described & Logistical notes \\
\hline $\begin{array}{c}\text { Provided foundational source for } 6,447 \text { personnel } \\
\text { considered most appropriate to include in analysis }\end{array}$ & $\begin{array}{c}\text { USGS Staff Profiles } \\
\text { expertise terms }\end{array}$ & $\begin{array}{c}\text { No Application Programming Interface (API) } \\
\text { required development of a web scraper and cached } \\
\text { data for processing; Numerous problems in data } \\
\text { quality required heavy filtering }\end{array}$ \\
\hline $\begin{array}{l}\text { Publicly accessible conduit to further identification } \\
\text { and affiliation information from an internal source, } \\
\text { including a unique historic record of former staff }\end{array}$ & People, organizations & ScienceBase Directory \\
\hline
\end{tabular}

\begin{tabular}{lcc}
\hline & ORCID Registry & Solid API conforming to a content standard. \\
\hline $\begin{array}{l}\text { Staff with ORCID identifiers pulled from several } \\
\text { reference points led to further details from the } \\
\text { ORCID registry }\end{array}$ & $\begin{array}{c}\text { People, organizations (by affiliation), } \\
\text { publications, subject matter terms }\end{array}$ & DOI Registry \\
\hline $\begin{array}{l}\text { DOI references for data, publications, and other } \\
\text { assets from many sources can be validated with } \\
\text { simple metadata in structured format containing } \\
\text { further references and relationships }\end{array}$ & $\begin{array}{c}\text { Publications, datasets, people (by affiliation as } \\
\text { contributors), subject matter terms }\end{array}$ & $\begin{array}{c}\text { Solid API conforming to a content standard with doi. } \\
\text { org serving as a broker to multiple DOI registries. }\end{array}$ \\
\hline $\begin{array}{l}\text { Reasonably comprehensive open data catalog } \\
\text { providing the most structured view of USGS data } \\
\text { assets }\end{array}$ & $\begin{array}{c}\text { People, organizations (by affiliation), people } \\
\text { (by affiliation), subject matter terms }\end{array}$ & $\begin{array}{c}\text { Custom API with some instability and no ability for } \\
\text { comprehensive queries requiring caching of data } \\
\text { for processing. }\end{array}$ \\
\hline $\begin{array}{l}\text { Developing resource describing scientific models and } \\
\text { documenting their inputs, outputs, software codes, } \\
\text { and other details }\end{array}$ & $\begin{array}{c}\text { Models, people, code repositories, linked } \\
\text { datasets }\end{array}$ & $\begin{array}{c}\text { Currently backed by ScienceBase with an accessible } \\
\text { but unstable API requiring caching of data for } \\
\text { effective processing. }\end{array}$ \\
\hline
\end{tabular}

Clearinghouse of USGS authored works (reports and articles) along with some data and other specialized products

\section{USGS Publications Warehouse}

Publications, datasets, people (by affiliation as contributors), organizations (by affiliation)
Custom API with some instability and no ability for comprehensive queries requiring caching of data for processing.
Technical findings regarding the many inconsistencies and issues in USGS underlying information systems and management processes, along with recommendations, are described elsewhere (Sky Bristol, USGS, written commun., 2021). A conceptual framework for how connecting this information can support the ongoing, iterative EarthMAP development process is described herein, and is likely applicable to other Bureau initiatives as well. A knowledge graph demonstrates how fusion of records of people, organizations, creative works, and open assets can provide a more holistic picture of these disparate pieces of information and their connectivity. Here, we provide two examples of visualization options for knowledge graphs that allow indirect links to infer logical links (figs. 5.1 and 5.2). Although the utility of these examples is constrained by flaws in the currency and correctness of the underlying data, they demonstrate how data can be connected in official ways. The graph allows capacity claims about a given person to be explored, presenting a compelling picture of a "scientific asset network." There are many ways that the graph form can be leveraged to bring all these various data streams together.

As a result of working through this experimental framework, we have produced working code that generates a reasonable knowledge graph that is continuing to be used in analysis for several ongoing use cases. We leveraged USGS cloud resources and a continuous data processing pipeline to mitigate some of the bigger challenges in our enterprise information systems. We have provided a design pattern, instantiated in a software package, that encapsulates the logic for building a knowledge graph from diverse source material. 


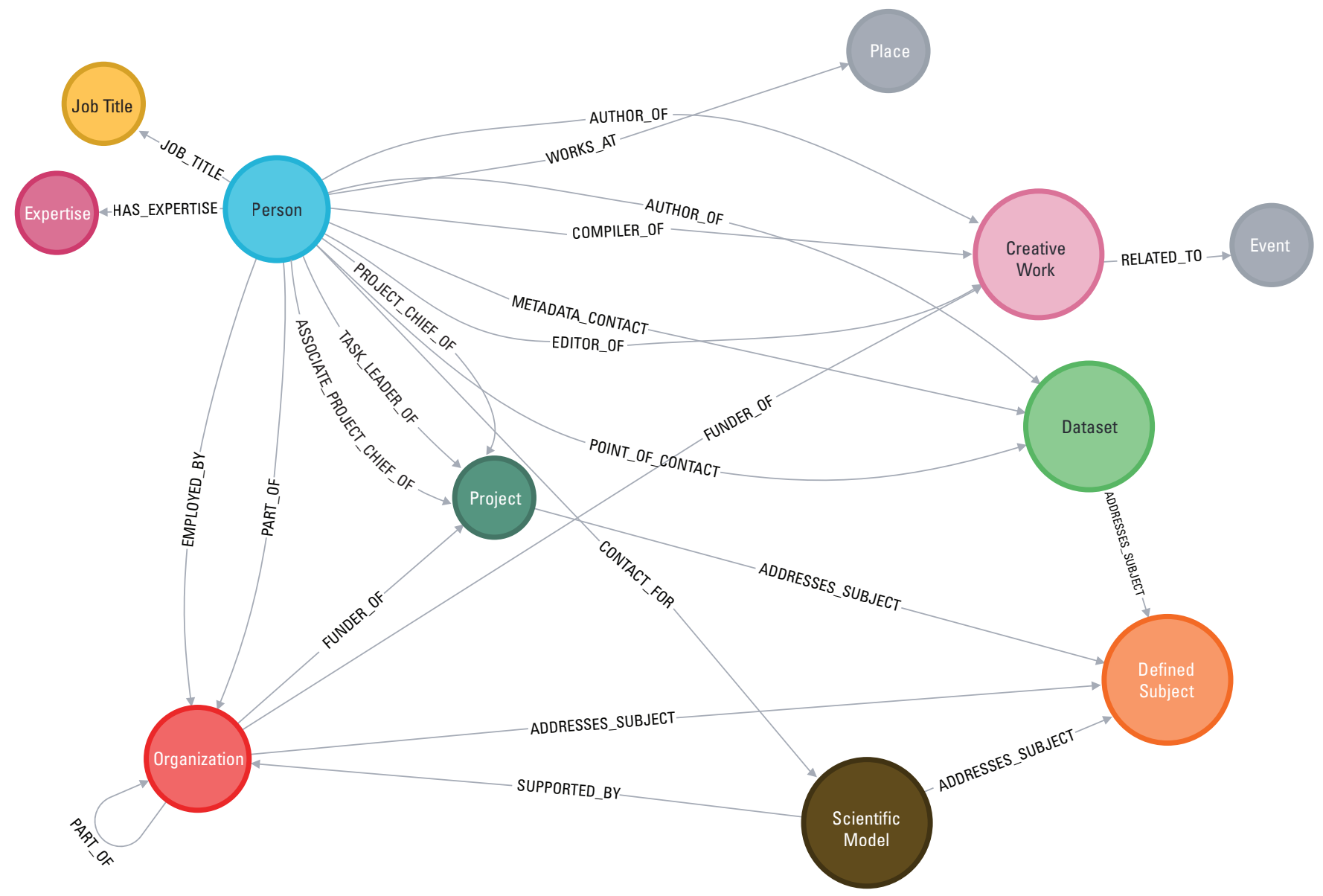

Figure 5.1. Nodes and relationships in the knowledge graph developed through the iSAID experiment. 


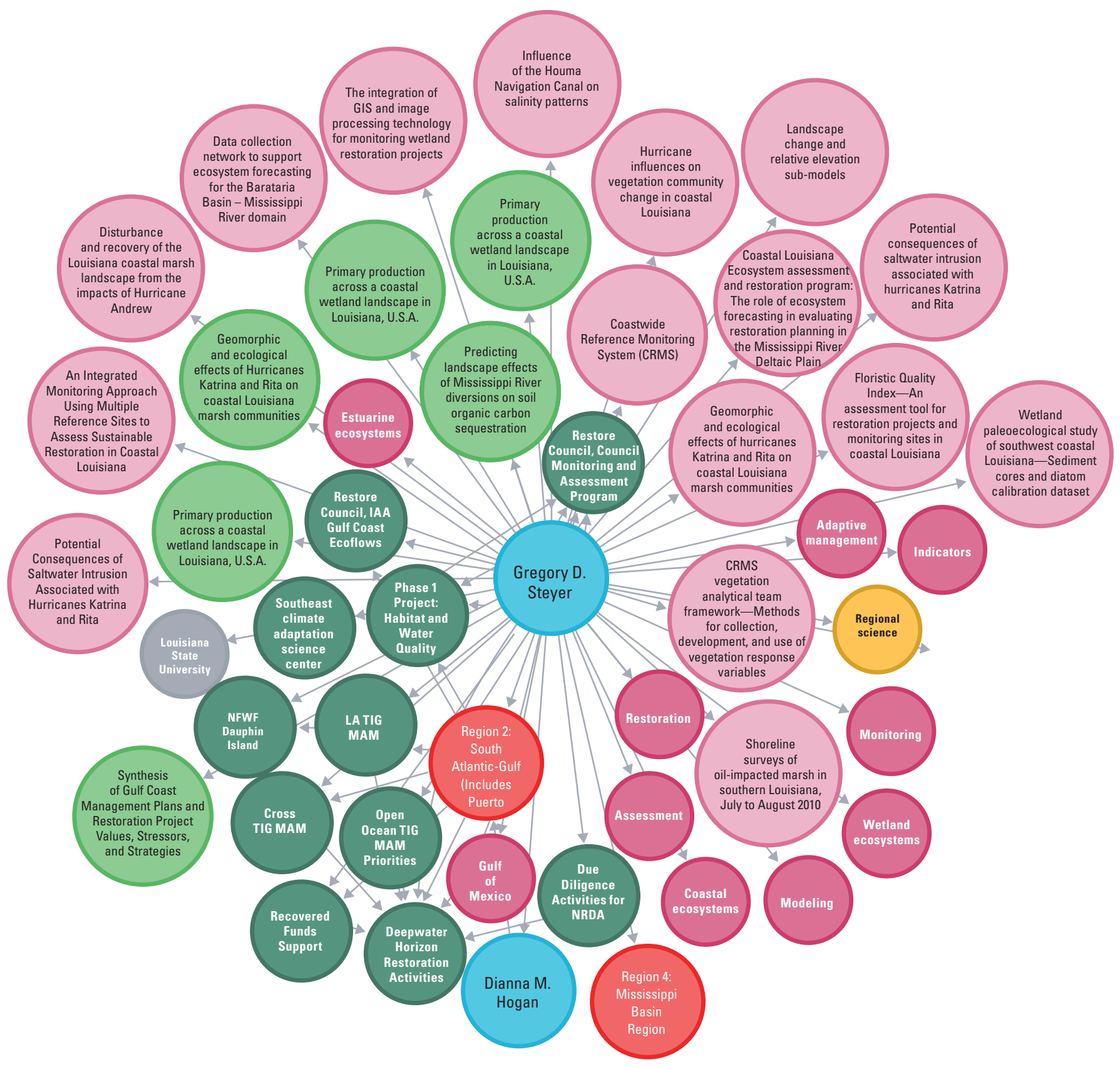

Figure 5.2. A knowledge graph depiction of an individual U.S. Geological Survey (USGS) scientist in the southeast region (in this case, Gregory D. Steyer, used with permission) based on information accessed from and linked across USGS Staff Profiles, Open Researcher and Contributor ID (ORCID), the DOI registry, USGS Publications Warehouse, and ScienceBase Directory. 


\section{Recommendations for Improving Availability of Information for Capacity Assessment and Other Uses}

Bureauwide recommendations for actions that will facilitate development of a continuously updated capacity information assessment capability include:

- Encourage staff to use and regularly update their USGS Staff Profiles to describe work, experience, and expertise. Use the USGS Thesaurus or other controlled vocabularies where possible for expertise terms.

- The USGS Staff Profiles system can be further developed to be more usable; capabilities for enhanced functionality may be available "off-the-shelf" (for example, Schema.org-metatag plugin for Drupal, https://www.drupal.org/project/schema_metatag).

- Continue adoption of ORCIDs for USGS staff that contribute to publicly available creative/scientific works of any kind. This would include not just first authors but any contributor to any released product. Encourage staff to maintain and update their ORCID identifier records as appropriate to fully characterize their work and affiliations.

- Require ORCIDs to be included in other information sources with staff information (for example, USGS Staff Profiles, project webpages, internal systems such as BASIS+).
- Develop and encourage staff and projects to use a shared and controlled vocabulary for describing work, experience, and expertise wherever information content is stored (for example, USGS Staff Profiles, ORCIDs, project webpages, ScienceBase, enterprise budget and project tracking tools). Potential information sources for controlled vocabulary include the USGS Thesaurus (https://www.vocabularyserver.com/usgs/) and Keywords (https://www.usgs.gov/products/data-andtools/data-management/keywords).

- Wherever information content is shared online through USGS webpages or other applications under USGS control, embed structured information and linkages to identifiers, such as ORCIDs.

- Metadata for all creative and published work that includes meaningful terms for places, time-periods or time-duration information, and subject matter, using and explicitly declaring controlled vocabularies and sources of definition.

\section{Reference Cited}

Helterbrand, W.S., and Sieverling, J.B., eds., 2008, Proceedings of the U.S. Geological Survey seventh biennial geographic information science workshop, Denver, Colorado, May 12-16, 2008: U.S. Geological Survey Scientific Investigations Report 2008-5074, 66 p., https://doi.org/10.3133/sir20085074. 
For more information concerning the research in this report, contact the

Director, U.S. Geological Survey

12201 Sunrise Valley Drive, Reston, VA 20192,

Reston, VA 20192

https://www.usgs.gov/

Publishing support provided by the U.S. Geological Survey Science Publishing Network, Sacramento Publishing Service Center 


\section{$\frac{\mathbb{2}}{\mathrm{C}}$}

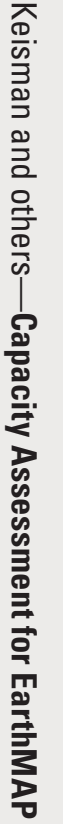

芒

突

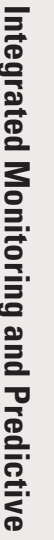

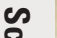

望

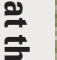

$\overline{\bar{\sigma}}$

¿ू.

i

逐

产

总

(a)

N 